ELIETE DA SILVA PEREIRA

\title{
O local digital das culturas: as interações entre culturas, mídias digitais e territórios
}




\title{
ELIETE DA SILVA PEREIRA
}

\section{O local digital das culturas: as interações entre culturas, mídias digitais e territórios}

\author{
Tese apresentada à Escola de \\ Comunicações e Artes da Universidade \\ de São Paulo para obtenção do título de \\ Doutora em Ciências da Comunicação. \\ Área de concentração: Interfaces sociais \\ da Comunicação. \\ Linha de Pesquisa: Comunicação, \\ Cultura e Cidadania. \\ Orientador: Prof. Dr. Waldenyr Caldas.
}


Autorizo a reprodução e divulgação total deste trabalho, por qualquer meio convencional ou eletrônico, para fins de estudo e pesquisa, desde que citada a fonte.

Pereira, Eliete da Silva.

O local digital das culturas - as interações entre culturas, mídias digitais e territórios / Eliete da Silva Pereira ; orientador Waldenyr Caldas. - São Paulo, 2013.

295 f. : il.

Tese (Doutorado)--Universidade de São Paulo, 2013. 
PEREIRA, Eliete da Silva. O local digital das culturas. As interações entre culturas, mídias digitais e territórios. Tese apresentada à Escola de Comunicações e Artes da Universidade de São Paulo para obtenção do título de Doutora em Ciências da Comunicação. Área de concentração: Interfaces sociais da comunicação.

Aprovado em:

Banca Examinadora

Prof. Dr. Instituição:

Julgamento: Assinatura:

Prof. Dr. Instituição:

Julgamento: Assinatura:

Prof. Dr. Instituição:

Julgamento: Assinatura:

Prof. Dr. Instituição:

Julgamento: Assinatura:

Prof. Dr. Instituição:

Julgamento: Assinatura: 
Aos meus pais, Netinha e Meira, Pelo amor, pela liberdade e pela acolhida a uma filha que sempre volta à casa. Sempre. 


\section{AGRADECIMENTOS}

Esta tese se constitui nos "entre-lugares", nos fluxos digitais, nas viagens, nos deslocamentos e nos encontros com pessoas, línguas e instituições. Por transitar em tantas paisagens e redes, como no manto do Arlequin narrado pelo filósofo Michel Serres, me dispo de meus retalhos e mostro, aqui, meus agradecimentos àqueles que deixaram suas marcas tatuadas na memória da pele desta tese.

Em especial, agradeço ao Prof. Dr. Waldenyr Caldas, orientador desta tese, pela gentileza e amizade. Também agradeço ao Prof. Alberto Abruzzese, coorientador do estágio sanduíche no Exterior, pela receptividade e generosidade com que sempre me apoiou quando estive na Universidade IULM de Milão.

Agradeço também à Massimo Di Felice pela interlocução, inspiração, incentivo e pelos (in)tensos debates. Sua presença e apoio em cada momento decisivo do desenvolvimento da pesquisa e da elaboração da tese foram fundamentais.

Agradeço aos professores da banca de avaliação pela disponibilidade em participar deste ritual dialógico.

Agradeço à Rosely Vieira de Sousa, secretária da PPGCOM-ECA/USP, por sua simpatia e profissionalismo, sempre disponível para ajudar os neófitos desse sistema complexo chamado "USP".

Agradeço também aos colegas e amigos do Centro de Pesquisa Atopos, que fazem parte dessa nova geração de pesquisadores/inventores dispostos a pensar os novos contextos digitais. Abdo, Andre Stangl, Bia Redko, Cadu Aguiar, Dayana Melo, Dora Kaufman, Erick Roza, Eli Ridolfi Jr., Fernanda Moreira, Julliana Cutolo, Leandro Yanaze, Mariana Marchesi, Mesac Silveira. Em especial, à Adriana Ramos, por ter me acompanhado em alguns encontros com meus interlocutores na França; e à lara de Melo Franco, por ter lido as primeiras versões desta tese e ter feito observações valiosas.

Agradeço aos meus interlocutores e aos amigos que fiz nesses deslocamentos: Angela Collado, Ailton Krenak, Gal Rocha, Gleyson Teixeira, Célia, Piongari e os vários jovens do Centro Yorenka Ãtame. À Benki Pianko pela abertura e pela hospitalidade nesse universo cósmico Ashaninka.

Aos amigos Brahim Slimani e Stephane Arrami, que me oportunizaram conhecer os circuitos digitais da "e-diáspora cabila", ajudando-me a montar essas conexões trans-mediterrâneas. 
Agradeço especialmente à minha querida amiga, Ivanise Rodrigues, que me acolheu carinhosamente em Rio Branco, sendo minha anfitriã no mundo da Floresta, seu apoio e dicas foram essenciais em minha estadia no Acre. Igualmente agradeço à querida Neli Miranda, que me recebeu tão bem em Cruzeiro do Sul e me apresentou às fronteiras Acre-Amazonas.

Com carinho, agradeço aos amigos Fabienne, Antonio Rafele, Fabio La Rocca, Valeria Binucci e petit Vitor, que veio ao mundo enquanto eu estava em Paris. Também um caloroso agradecimento a Mario Pireddu, Luca Nardi, Caterina LaProva, que direta e indiretamente também deixaram suas marcas nesta tese.

Agradeço à Mirela Adriele da Silva Castro, pela revisão e formatação da tese, participação essencial quando o tempo nos escapa.

Agradeço à Wanderson Chaves, amigo de aventuras uspianas, assim como eu, filho do deslocamento e do trânsito, de lá do Planalto Central, onde o céu é o mar.

Agradeço à Agnes, amiga e companheira de turma do doutorado, pelas conversas e encontros sempre agradáveis, agora com Júlia, um motivo a mais de boas prosas.

À Lucia Fabrizi, Nonno Alberto, Fabio e Natasha, pela paciência e pelo carinho com que me receberam quando estive na Itália. Naqueles momentos de usência típicos do ato solitário da escritura, eles estiveram ali, colaborando silenciosamente em minhas imersões.

Agradeço ao caro amigo Marcos Alexandre, pela ajuda no tratamento das ilustrações que compõem esta tese. Igualmente, agradeço ao amigo Glauber Queiroz pela força na reta final.

Agradeço especialmente a essa outra parte importante de mim: minha família. Meus pais, Netinha e Meira; meus irmãos, Jean, Jane, Mércia; meus sobrinhos, Gabriel, Pablo e Vinícius; e meus cunhados, Manoel e Eliana. Todos permeiam o meu Ser no mundo.

A todos aqueles que mesmo não citados e que de alguma forma participaram desta tese, meus mais sinceros agradecimentos.

E, finalmente, agradeço à Coordenação de Aperfeiçoamento de Pessoal de Nível Superior (Capes), pela concessão de bolsa de pesquisa (2009-2013) e pela bolsa de estágio sanduíche no exterior (março a agosto de 2012). 


\section{RESUMO}

PEREIRA, E. P. O local digital das culturas. As interações entre culturas, mídias digitais e territórios. 2013. $295 \mathrm{f}$. Tese (Doutorado) - Escola de Comunicações e Artes de São Paulo, Universidade de São Paulo, São Paulo, 2013.

No interior do amplo processo de digitalização, que se caracteriza como um qualitativo fenômeno de dinamismo e de transformação sociocultural, difunde-se, em diversos contextos e por diversas modalidades, um importante processo de digitalização de grupos étnicos. Tal realidade é responsável não somente por um processo de tradução digital de saberes e culturas locais, mas, ao mesmo tempo, pela instauração de um importante processo de alteração da condição habitativa dessas culturas. De fato, ao conectar-se às redes digitais, uma comunidade expande seu território e seu ecossistema, estendendo-o por meio de um dinamismo metageográfico que o conecta aos outros contextos e culturas e a outros mundos. Criase, assim, um complexo ecossistema que une reticularmente os grupos envolvidos, suas culturas, seus territórios, aos circuitos informativos digitais através de um singular dinamismo tecno-comunicativo-habitativo. Nesse sentido, a pesquisa da qual resultou esta tese objetivou investigar o processo de digitalização decorrente das relações entre "culturas, mídias digitais e territórios" - inspirada no conceito do habitar (HEIDEGGER, 1951; ABRUZZESE, 2006; DI FELICE, 2009). Para isso, realizamos uma pesquisa experimental baseada na imersão, na interação, na observação, na interpretação e na comparação de experiências que se desenvolvem reticularmente, propondo, portanto, uma leitura teórica em torno dos significados do "local digital das culturas". Tal objetivo foi alcançado pela descrição dos dinamismos associativos dos seus atores-redes (LATOUR, 2004, 2012) mediante o estudo comparativo de dois casos exemplares. A Rede Povos da Floresta compreende o processo de digitalização das culturas e das territorialidades de comunidades situadas na região amazônica e a "e-diáspora" dos povos cabilas, originários dos povos berberes (Amazigh) do norte da Argélia, atualmente espalhados no mundo e reunidos nas redes digitais. No primeiro caso, a digitalização significou, além da disseminação dos saberes tradicionais dos Povos da Floresta, a criação de um complexo ecossistema informativo emergente (MORIN, 2001), que estende sua rica biodiversidade a uma dimensão tecno-informativa. No caso da "e-diáspora" cabila, a digitalização proporcionou um ecossistema informativo que tornou possível a reunião, a disseminação, a tradução da cultura amazigh (berbere) nos fluxos informativos das redes digitais. $O$ estudo e a análise desses dois casos nos permitiram problematizar o conceito de social, abrindo-nos a uma perspectiva reticular e conectiva do mesmo.

Palavras-chave: comunicação digital, culturas locais, mídias digitais, territorialidade, redes digitais, habitar, diáspora. 


\begin{abstract}
PEREIRA, E. P. The digital local of cultures - the interaction between cultures, digital media and territories. 2013. 295 f. Tese (Doutorado) - Escola de Comunicações e Artes de São Paulo, Universidade de São Paulo, São Paulo, 2013.

In the interior of the extensive process of digital conversion, which is characterized by a qualitative dynamic phenomenon and by socio-cultural transformation, an important process of digital transformation of ethnic groups is diffused, in various contexts and by diverse modalities. Such reality is responsible not only for a process of digital translation of wisdom and local cultures, but, at the same time, for the implementation of an important process of alteration of the dwelling conditions of these cultures. In fact, in connecting with digital networks, a community expands its territory and ecosystem, extending it by a means of a dynamic metageography which connects it to other contexts and cultures and to other worlds. Thus is created a complex ecosystem which reticularly unites the involved groups, their cultures, their territories, to digital informational circuits through a singular dynamism of techno-living-communication. In this sense, the object of the research which resulted in this thesis was the investigation of the process of digital transformation, deriving from the relationship between "cultures, digital media and territories" - inspired by the concept of Dwelling (HEIDEGGER, 1954; ABRUZZESE, 2006; DI FELICE, 2009). For this we realized an experimental research based on immersion, interaction, in observation, in interpretation, and the comparison of the experiences which are reticularly developed, proposing, therefore, a theoretical reading in terms of the "digital local of cultures". Such objective was reached by the description of the associative dynamisms of its actor-networks (LATOUR, 2004, 2012), by means of a comparative study of two exemplary cases. The Network of the People of the Forests understand the digital transformation of cultures and territories of communities situated in the Amazon region; and the e-diaspora of the Kabyla people, descendants of Berbers (Amazigh) of the north of Algeria, actually spread throughout the world and connected by digital networks. In the first case, this transformation signified, besides the dissemination of the traditional wisdom of the People of the Forest, the creation of an emerging complex informational ecosystem (MORIN, 2001), which extends its rich biodiversity to a techno-informational dimension. In the case of the Kabyla "e-diaspora", this transformation provided an informational ecosystem which made possible the reunion, the dissemination, and the translation of the information flows through digital media. The study and analysis of these two cases permits us to problematize the social context, opening us to a reticular perspective and connection of this social context.
\end{abstract}

Keywords: digital communication, local cultures, digital media, territories, digital networks, dwelling, diaspora 


\section{LISTA DE FIGURAS}

Figura 1 - Captura do site da Rede Povos da Floresta ................................... 107

Figura 2 - Captura de tela do site Rede Povos da Floresta "Quem somos"....... 112

Figura 3 - Foto de Alice Fortes - Ponto de Cultura Demini .............................. 125

Figura 4 - Captura de trecho do Vídeo "A gente luta mas come fruta" (2006) .... 126

Figura 5 - Captura de trecho do vídeo da Primeira Roda de Conversa .............. 133

Figura 6 - Captura de tela conversa com Ailton Krenak (Facebook, 6/11/2012)...139

Figura 7 - Mapa da Terra Indígena do Kampa .................................................148

Figura 8 - Captura da tela do Blog Saberes da Floresta .................................... 166

Figura 9 - Captura da tela blog da Associação Ashaninka Apiwtxa ......................167

Figura 10 - Mapa da Grande Cabília (Argélia) .................................................184

Figura 11 - Mapa das populações berberes na região do Magrebe .....................185

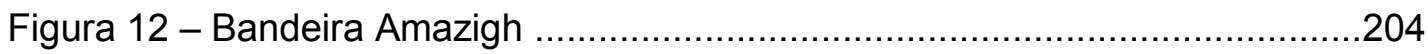

Figura 13 - Perfil de Brahim Slimani no Facebook .............................................208

Figura 14 - Captura das fotos da página do Kabyle.com no Facebook manifestação em defesa do território Azawad (Mali) em Paris, 07/07/2012 .........229

Figura 15 - Página do Kabyle.com no Facebook ..............................................235

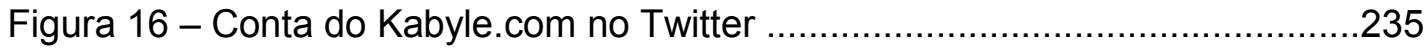

Figura 17 - Captura de tela do Portal Kabyle.com ..........................................239 


\section{LISTA DE ABREVIATURAS E SIGLAS}

ABCiber Associação Brasileira de Pesquisadores em Cibercultura

ACM Associação de Cultura e Meio Ambiente

ACONAMAC Asociación de Comunidades Nativas de Ashaninkas de Masisea y Calleria

AKFI Association Kabyle-France-Internacional

APEL Pesquisa e Desenvolvimento de Projeto

ARPA Áreas Protegidas da Amazônia

CCADA Conselho das Comunidades Afrodescendentes

CDI Comitê para a Democratização da Informática

CIMI Conselho Indigenista Missionário

CNRS Centre national de la recherche scientifique

CPI Comissão Pró Índio

CRAPE Centre de Recherches en Anthropologie, Préhistoire et Ethnologies

CTI Centro de Trabalho Indigenista

CYA Centro Yorenka Ãtame

ELN Exército de Libertação Nacional

FFS Front des Forces Socialistes

FIS Frente Islâmica da Salvação

FLN Front de libération nationale

FOIRN Federação das Organizações Indígenas do Rio Negro

FSC Forest Stewardship Council

FUNAI Fundação Nacional do Índio

FUNBIO Fundo Brasileiro para a Biodiversidade

GESAC Governo Eletrônico: Sistema de Apoio ao Cidadão

GIA Grupo Islâmico Armado

GFBV Gesellschaft für bedrohte Völker (GfbV)

GPK Gouvernement provisoire Kabyle (GPK)

GPS Global Positioning System

HCA Haut-Commissariat à L'Amazighitè 
IBAMA Instituto Brasileiro do Meio Ambiente e dos Recursos Naturais Renováveis

IBOPE Instituto Brasileiro de Opinião Pública e Estatística

ICMBio Instituto Chico Mendes de Conservação da Biodiversidade

INCRA Instituto Nacional de Colonização e Reforma Agrária

INPI Instituto Nacional da Propriedade Industrial

IRMC Institut de Recherche sur le Maghreb Contemporain

ISA Instituto Socioambiental

IULM Libera Università di Lingue e Comunicazione

JET Jeunesse Électronique de Tizi-Ouzou

JSK Jeunesse Sportive de Kabylie

LADH Ligue Algérienne dês Droits de l'Homme

MAK Mouvement pour l'Autonomie de la Kabylie

MCB Mouvement Cultural Berbere

MCBD Movimento Cultural Berbere e da Democracia

MinC Ministério da Cultura

MTLD Mouvement pour le triomphe des libertés démocratiques

$\mathrm{NCl} \quad$ Núcleo de Cultura Indígena

NTE Núcleo de Tecnologia Educacional

ODA Overseas Development Agency

OIT Organização Internacional do Trabalho

OPIAC Organização dos Professores Indígenas do Acre

$\mathrm{PCl} \quad$ Pontos de Cultura Indígenas

PDT Partido Democrático Trabalhista

PPA Parti Du Peuple Algérien

ProNEA Programa Nacional de Educação Ambiental

PRS Parti de la revolution socialiste

PT Partido dos Trabalhadores

RCAB Rede de Cooperação Alternativa Brasil

RCD Rassemblement pour la culture et la démocratie

RPF Rede Povos da Floresta

SAFs Sistemas Agroflorestais

SARL Société à responsabilité limitée

T.I. Terra Indígena 


$\begin{array}{ll}\text { UFAC } & \text { Universidade Federal do Acre } \\ \text { UnB } & \text { Universidade de Brasília } \\ \text { UNI } & \text { União das Nações Indígenas } \\ \text { USP } & \text { Universidade de São Paulo } \\ \text { VNA } & \text { Vídeo nas Aldeias } \\ \text { WWF } & \text { World Wildlife Fund }\end{array}$




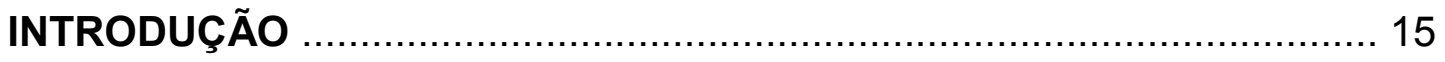

PARTE I - TRÂNSITOS TEÓRICOS E METODOLÓGICOS DO LOCAL

DIGITAL DAS CULTURAS

CAPÍTULO I - UM MAPA TEÓRICO-METODOLÓGICO DAS

INTERAÇÕES ENTRE CULTURAS, MÍDIAS DIGITAIS E TERRITÓRIOS..26

1.1 PRESSUPOSTOS EPISTÊMICOS INICIAIS 30

1.2 TRÍADE SIMBIÔNTICA: CULTURAS, MÍDIAS DIGITAIS E

TERRITÓRIOS. .48

1.2.1. Culturas: produção comunicativa de significados e horizonte hidrizante...... 49

1.2.2. Mídias digitais .56

1.2.3. Metaterritórios e espacialidades comunicativas 63

CAPÍTULO 2 - PERCURSO INVESTIGATIVO: NOS CIRCUITOS IMERSIVOS, DIALÓGICOS E ATÓPICOS DAS/NAS REDES DIGITAIS ...70 2.1 IMERSÕES E CONEXÕES NAS ARQUITETURAS INFORMATIVAS

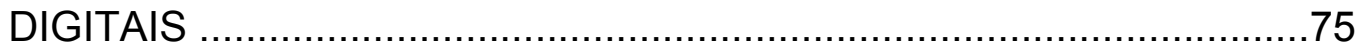

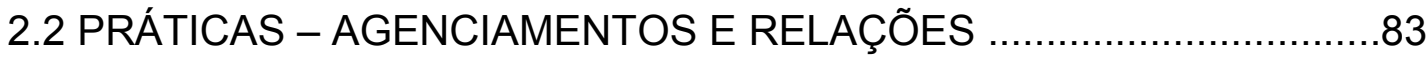

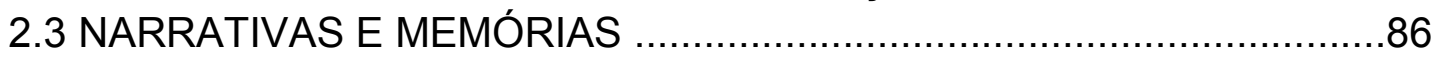

2.4 INTERSUBJETIVIDADES E PESQUISA INSIDER ............................8

PARTE II - A REDE POVOS DA FLORESTA E A ECOLOGIA XAMÂNICA

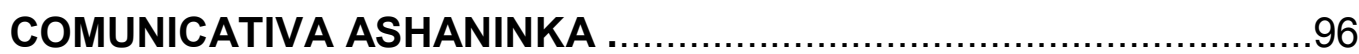

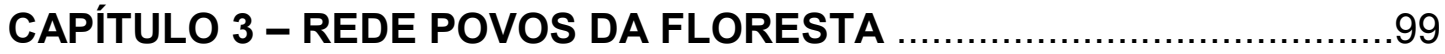

3.1 A ALIANÇA E A REDE POVOS DA FLORESTA …..........................100

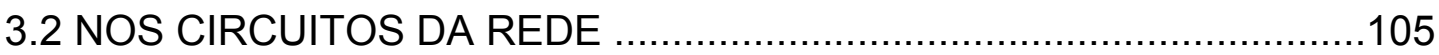

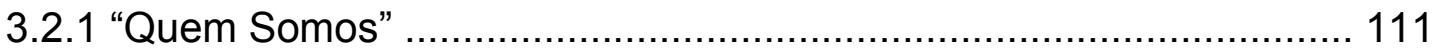

3.2.2 "O que fazemos" e "A Rede Povos da Floresta" ............................116

3.2.3 "Nossa história" .....................................................................118

3.2.4 "Agenda", "Clipping" e "Notícias e Ações" .........................................119

3.2.5 "Pontos de Cultura Indígena" ......................................................120

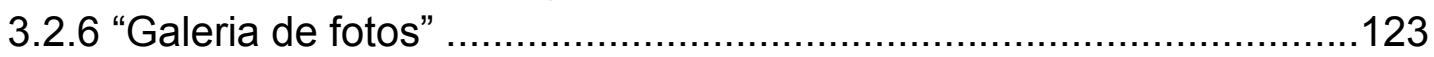

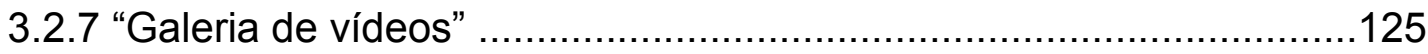

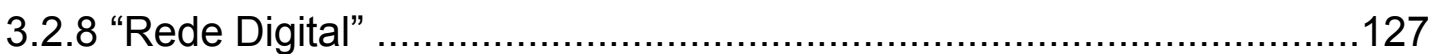

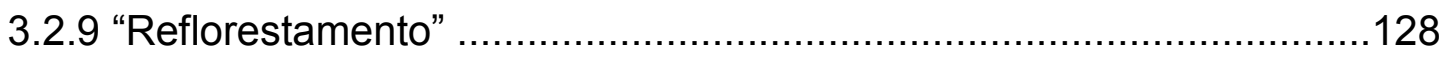

3.2.10 "Buscas", "links" e "Fale conosco" ............................................128

3.3 CRONOLOGIA DAS ASSOCIAÇÕES E DOS ATORES-REDES .........129 
CAPÍTULO 4 - CENTRO YORENKA ÃTAME E A ECOLOGIA XAMÂNICA COMUNICATIVA ASHANINKA.

4.1 COSMOLOGIA E HISTÓRIA DA POLÍTICA INTERÉTNICA ASHANINKA DO AMÔNIA 143

4.2 A ERA DOS PROJETOS SUSTENTÁNVEIS E O CENTRO YORENKA ÃTAME 155

4.3 NOS CIRCUITOS DA ECOLOGIA XAMÂNICA COMUNICATIVA ASHANINKA 159

4.3.1 Mediascape I - paisagens midiáticas audiovisuais .........................159

4.3.2 Mediascape II - paisagens midiáticas sonoras ................................163

4.3.3 Mediascape III - paisagens midiáticas digitais .................................165

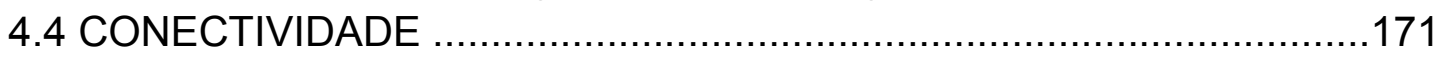

4.5 TRÍADE SIMBIÔNTICA ASHANINKA ..............................................172

PARTE III - O PORTAL KABYLE.COM E A E-DIÁSPORA CABILA .......179

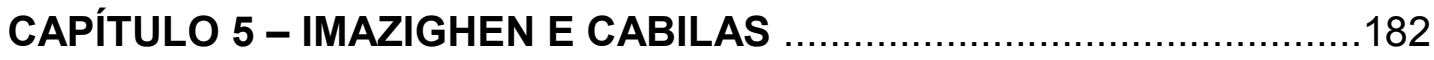

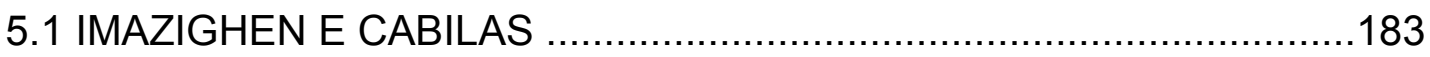

5.1.1 Islã, laicidade e organização política local .....................................187

5.1.2 Sincretimos: o islã cabila, rituais e festas ......................................190

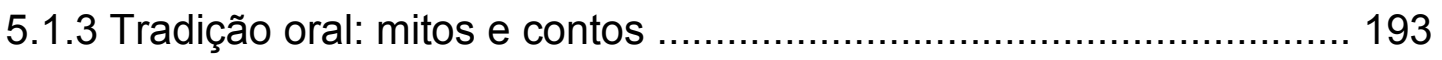

5.1.4 Literatura oral e produção audiovisual ............................................196

5.1.5 Tradição musical ....................................................................199

5.2 COLONIZAÇÃO FRANCESA, INDEPENDÊNCIA E PÓS-

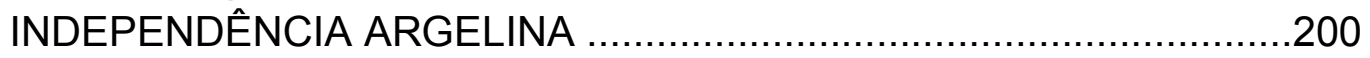

5.3 PRIMAVERA BERBERE E MOVIMENTO CULTURAL .......................206

5.4 PRIMAVERA NEGRA E GRUPOS POLÍTICOS CABILAS .................208

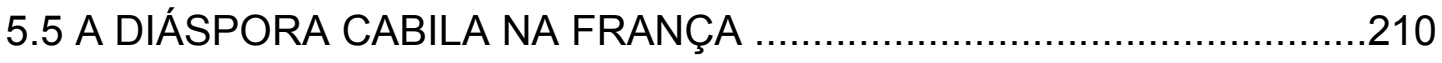

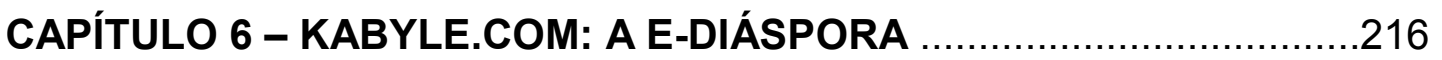

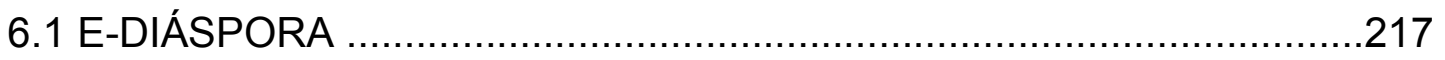

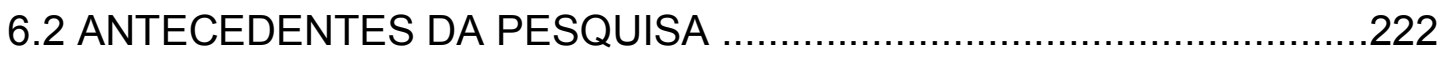

6.3 NOS CIRCUITOS DA E-DIÁSPORA CABILA - PESQUISA PRELIMINAR

6.4 NOS CIRCUITOS DA E-DIÁSPORA - KABYLE.COM ……...............230

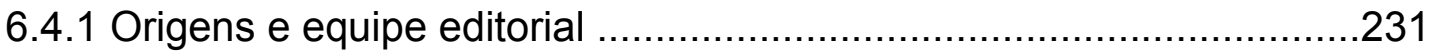

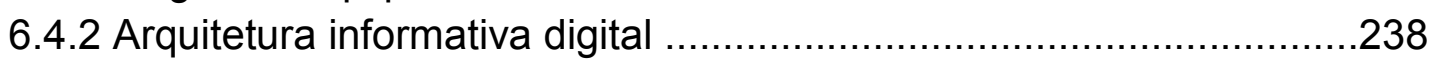

6.5 TRÍADE SIMBIÔNTICA DA E-DIÁSPORA CABILA ...........................244

CONSIDERAÇÕES FINAIS - OS SIGNIFICADOS DO LOCAL DIGITAL

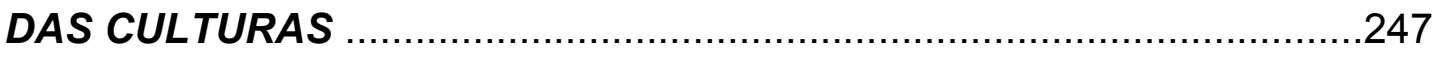

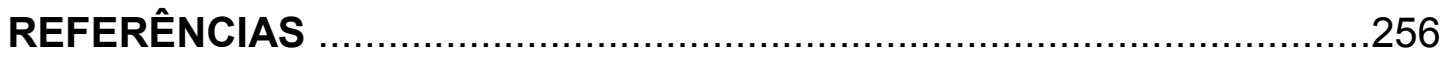




\section{APÊNDICE}

.269

ANEXOS 


\title{
INTRODUÇÃO
}

\author{
Uma fronteira não é o ponto onde algo termina, \\ mas, como os gregos reconheceram, a fronteira é o ponto a \\ partir do qual algo começa a se fazer presente. \\ Martin Heidegger (apud BHABHA, 1998, p. 20) \\ As redes informativas promovidas pelas mídias \\ digitais propõem aos indivíduos um ponto de vista \\ relativamente holístico da sociedade um horizonte mais \\ vasto com o qual confrontar os seus destinos individuais [...] \\ oferecendo às pessoas uma nova perspectiva da qual \\ observar as suas ações e as suas identidades. \\ Joshua Meyrowitz (1995, p. 31)
}

O fenômeno global da difusão das tecnologias digitais de informação e comunicação vem sendo acompanhado por um crescente processo de digitalização das culturas locais que envolve, em um nível local e transnacional, a promoção das interações entre grupos (com identificações étnicas) e dispositivos técnicos de acesso à internet, corroborando, assim, para a participação cada vez maior de culturas e saberes locais nos circuitos digitais.

No Brasil, em particular, tal processo ocorreu com mais abrangência por meio de políticas públicas de inclusão digital, sobretudo pelo Programa GESAC $^{1}$ e pelos Pontos de Cultura $^{2}$ desenvolvidos respectivamente pelos Ministérios das Comunicações e da Cultura, órgãos do governo federal. Fora desse âmbito nacional, em várias partes do mundo, culturas e comunidades locais interagem com os dispositivos e as redes digitais. Dessa forma, a conexão digital desses grupos parece que, além de proporcionar a expressão das suas diferenças, Ihes permite potencializar o fortalecimento dos seus vínculos sociais e a reelaboração dos seus repertórios culturais.

\footnotetext{
${ }^{1}$ Criado em 2002, o programa GESAC - Governo Eletrônico: Serviço de Atendimento ao Cidadão oferece conexão de internet via satélite e terrestre a telecentros em várias comunidades em estado de vulnerabilidade social.

${ }^{2}$ São projetos oriundos de iniciativas já existentes da sociedade civil que passaram a ser financiados e apoiados institucionalmente pelo Ministério da Cultura do Brasil (MinC). Implementados por entidades governamentais e não governamentais, os Pontos de Cultura visam a realização de ações de impacto sociocultural em comunidades locais. Por ser uma ação prioritária do Programa Cultura Viva do MinC desde 2004, além do apoio a manifestações culturais das mais diversas, os Pontos de Cultura proporcionaram a disseminação da cultura digital, com a implantação de equipamentos de acesso à internet e de registro audiovisual.
} 
No entanto, embora seja um fenômeno crescente e tenha, no caso do Brasil, políticas públicas específicas, vem sendo pouco estudado do ponto de vista mais amplo, que considera tanto os fatores culturais quanto aqueles midiáticos digitais e territoriais $^{3}$.

Por considerar a importância desta temática e em vista da lacuna de estudos sobre a mesma, esta tese teve como objetivo principal investigar esse processo que levou diversas culturas locais a estarem conectadas aos circuitos digitais, fazendose presentes nas novas fronteiras e espacialidades informativas. Como resultado desse processo manifesta-se, assim, aquilo que identifiquei como o local digital das culturas - uma expressão oxímora ${ }^{4}$ inspirada na obra $O$ local das culturas do crítico cultural Hommi Bhabha $(1998)^{5}$-, delineado pela ação comunicativa digital de grupos locais e suas implicações para com seus territórios e suas identidades.

Modulam-se, portanto, nas entranhas dessas dinâmicas comunicativas, novas percepções e transformações da localidade - compreendida, assim, mais do que por sua expressão limitada à localização geográfica, por sua relatividade situacional integrada às tecnologias digitais de informação e comunicação. Isto é, essas localidades, por meio das suas conexões informativas, passam a estar profundamente associadas aos contextos comunicativos globais e transnacionais.

Diante desses espaços glocalmente ${ }^{6}$ localizados e atravessados por sistemas comunicativos interativos devido a suas arquiteturas digitais (sites, blogs e portais,

\footnotetext{
${ }^{3}$ Entre 2009 a 2012, realizamos um levantamento nos bancos de teses da CAPES e nos bancos de dados (livros, dissertações e teses) da Universidade de São Paulo e da Universidade de Brasília. Verificamos também os trabalhos apresentados nas duas últimas edições (2011 e 2012) do Simpósio Nacional da Associação Nacional de Pesquisadores em Cibercultura (Abciber), o que demonstra que, embora comece a existir um interesse discreto sobre a participação de grupos com identidades étnicas, como as indígenas na internet, não localizamos estudos específicos sobre a digitalização de culturas locais sob um aspecto que contemple suas relações culturais, midiáticas e territoriais.

${ }^{4}$ A palavra oxímoro descreve uma figura de linguagem expressa por seus significados opostos.

${ }^{5}$ Publicação original: Bhabha, H. The location of culture. Routledge-London: New York, 1994.

"Referimo-nos ao termo "glocal" - discutido por Roland Robertson (1999) - como sendo mais adequado que o termo "global" para designar as tendências de homogeneização e heterogeneização, aparentemente contrapostas, mas que são complementares e interpenetrantes. Robertson amplia o termo "glocal", apresentado no Oxford Dictionary of New Words, no qual é mencionado como baseado na noção japonesa dochaku, "viver na própria terra", adoção de princípios agrícolas às condições locais. Mais tarde,na década de 1980, o termo tornava-se o jargão do marketing, pelo qual se disseminou referindo-se à técnica do micromarketing: "personalização e comercialização de produtos e serviços de base global ou quase global em escala local e para mercados específicos cada vez mais diferenciados" (ROBERTSON, 1999, p. 251). Robertson vai além desse sentido e se vale da ideia geral de glocalização para problematizar as dicotomias entre o local e o global. É interessante citar o comentário de uma de suas colegas japonesas, que menciona o sentido não comercial da palavra dochakuka, que se relaciona à ideia de "tornar algo indígena" (ROBERTSON, 1999, p. 252).
} 
etc.), a pesquisa que resultou nesta tese desenvolveu-se no campo comunicacional, estabelecendo um diálogo transdisciplinar com estudiosos da sociologia, da filosofia, da crítica cultural, da antropologia, dentre outros. Precisamente, o objeto desta tese - o processo de digitalização das culturais locais - é teorizado mediante o diálogo com autores oriundos de diversas áreas, entre eles dos estudos culturais e póscoloniais (HALL, 2003; APPADURAI, 2001; BHABHA, 1998; entre outros), numa perspectiva diversa, inserindo, no debate proposto por esses autores - sobre os processos de transformação cultural -, as mudanças relacionadas aos processos digitais. Minha opção foi avaliar uma localidade com qualidade fenomenológica, que se manifesta enquanto forma comunicativa do habitar, dada a simbiose entre sujeitos, culturas, mídias digitais e território, como referido pelo sociólogo Massimo Di Felice (2009); enquanto modo de estar no mundo, proposto pelo filósofo Martin Heidegger (1954); e como peculiar forma técnica de habitar as mídias, assim designado pelo sociólogo Alberto Abruzzese (2006).

Tal referencial teórico resulta da reflexão ocasionada pelas atividades realizadas no Centro de Pesquisa ATOPOS (ECA-USP), principalmente por minha participação em grupos de pesquisa, seminários e simpósios nacionais e internacionais organizados pela instituição, no intuito de ampliar o debate sobre a influência das novas tecnologias de comunicação nos diversos âmbitos da sociedade, passando pelas especificidades sociais e culturais, associadas às mudanças perceptivas e cognitivas geradas pelas interações entre sujeitos e tecnologias. No ATOPOS, tive a possibilidade de entrar em contato com interlocutores privilegiados, desde importantes estudiosos, como o sociólogo Alberto Abruzzese, meu coorientador no estágio da bolsa sanduíche, como realizar diálogos com os pesquisadores da minha geração, que estão, assim como eu, repensando novos objetos e métodos de pesquisa a partir do estudo das redes digitais ${ }^{7}$.

Meu interesse por esta temática teve origem, de alguma forma, em uma indagação advinda da minha trajetória acadêmica, iniciada no curso de História, particularmente na pesquisa que desenvolvi na área de história das ideias no contexto latino-americano, com os estudos dos discursos sobre a cultura e a

\footnotetext{
${ }^{7}$ No Centro de Pesquisa ATOPOS (ECA/USP), realizamos seminários internos de pesquisa mensais, nos quais os pesquisadores apresentam e debatem o andamento de suas pesquisas individuais.
} 
diferença ${ }^{8}$; e nas ciências sociais, com a pesquisa de Mestrado ${ }^{9}$ sobre a presença indígena brasileira na internet, com o estudo exploratório dos sites indígenas sob a leitura de uma experiência cyborg ${ }^{10}$, recentemente publicado em forma de livro, intitulado Cibogues indígen@s.br: a presença nativa no ciberespaço (Annablume, 2012). Essa investigação me levou a coordenar, junto com o Prof. Massimo Di Felice, nos anos de 2006 e 2008, o Seminário 'Mídias Nativas”, evento que promoveu o debate sobre as experiências midiático-digitais de comunidades indígenas e jovens de periferia, com a presença destes e de especialistas acadêmicos.

Minha pesquisa de Mestrado me aproximou, de fato, do campo da comunicação, o que me fez optar pelo Doutorado em Ciências da Comunicação, no intuito de aprofundar alguns aspectos que haviam se sobressaído no estudo da presença indígena no ciberespaço, em especial as interações em rede realizadas por sujeitos historicamente marginalizados pelas mídias de massa e que, na internet, por meio das mídias digitais, realizavam um determinado protagonismo, envolvendo também suas relações com seus territórios.

Portanto, motivada por essa temática elaborei uma primeira versão do meu projeto, sendo aprovada na seleção do Doutorado na área de concentração "Interfaces Sociais da Comunicação", na linha de pesquisa: "Comunicação, cultura e cidadania", sob a orientação do prof. Waldenyr Caldas, que me concedeu a oportunidade de desenvolver a pesquisa.

Durante o desenvolvimento da investigação que resultou nesta tese, orienteime pelo seguinte problema de pesquisa: como e em que medida os elementos interagentes e interdependentes - culturas, mídias digitais, territórios - combinam-se

\footnotetext{
${ }^{8}$ Realizei pesquisa do PIBIC e monografia de final de curso sobre os elementos étnicos e culturais presentes nos discursos de Simon Bolívar na tentativa de constituição da III República na região atual da Venezuela. A pesquisa propôs uma reflexão sobre as imagens das gentes de colores nos discursos de Bolívar, no momento da construção do discurso sobre a "nação americana" (18151819).

${ }^{9}$ Realizei o Mestrado sob a orientação do antropólogo, professor e doutor Cristhian Teófilo da Silva, no Centro de Pesquisa e Pós-Graduação sobre as Américas do Instituto de Ciências Sociais da Universidade de Brasília (UnB).

10 Para interpretar o sentido dessa experiência comunicativa indígena no ciberespaço, propus a metáfora do ciborgue (HARAWAY, 1984) enquanto imagem evocativa e provocativa capaz de traduzir a relação simbiótica entre grupos/sujeitos indígenas e tecnologia. Uma nova condição nativa contemporânea, atravessada por softwares e hardwares, sistemas informativos e fluxos comunicativos. Nesse sentido, essa pesquisa apontou para a atuação nativa no ciberespaço, promotora de um diálogo intercultural estabelecido por uma situação social, tecnológica, comunicativa e em rede.
} 
e relacionam-se segundo as experiências de coletivos $^{11}$ que se autoidentificam de acordo com critérios de pertencimento étnicos.

Visando responder a essa problemática, busquei analisá-la à luz do conceito do habitar, desenvolvido por Martin Heidegger (1954), Alberto Abruzzese (2006) e Massimo Di Felice (2009) e a partir da imersão, da interação, da observação, da interpretação e da comparação de experiências desenvolvidas reticularmente, propondo uma leitura teórica desse local digital das culturas, enquanto expressão dos dinamismos comunicativos associativos dos seus atores-redes ${ }^{12}$ (LATOUR, 2004, 2012), das culturas e de seus territórios expandidos, situados na "tríade simbiôntica”, nas relações ecológicas e simbióticas, portanto, recíprocas e interativas entre culturas, mídias digitais e territórios.

Nesse sentido, a análise desenvolvida nesta tese procurou redimensionar essas relações para além de uma reflexão instrumental das tecnologias digitais de comunicação. Buscou-se, então, articulá-las enquanto ecossistemas informativos complexos (MORIN, 2011), segundo uma perspectiva reticular (DI FELICE, 20112012), parcial, situada e provisória.

Ao tratar desse tipo de problema circunscrito ao local que se digitaliza e seu desdobramento nos modos de perfomatização das identidades e nas formas comunicativas do Habitar, selecionei dois casos reticulares e exemplares para a análise comparativa: um nacional, a Rede Povos da Floresta, incluindo a ecologia xamânica comunicativa do povo indígena Ashaninka; e outro internacional, a "ediáspora" dos povos cabilas/berberes.

A escolha da Rede Povos da Floresta (RPF) visou compreender essa experiência que reinscreveu a Aliança dos Povos da Floresta, um movimento social e ambiental muito forte no Acre na década de 1980, revitalizando-a ao buscar conectar digitalmente as comunidades tradicionais, sobretudo as da região amazônica. Investiguei um dos polos da Rede Povos da Floresta, o Centro Yorenka Ãtame, que representa, hoje, uma importante ação reticular do povo Ashaninka do rio Amônia (situados na região do Alto Juruá, Acre). De forma bastante criativa e original, esse povo reconfigurou seus sistemas de trocas tradicionais e sua

\footnotetext{
${ }^{11}$ Baseio-me no "coletivo" teorizado por Bruno Latour, que diz respeito a um tipo de procedimento de coligar as associações entre humanos e não humanos. Ao longo da tese, o termo será aprofundado.

${ }^{12}$ A noção "ator-rede" também se refere àquela elaborada por Bruno Latour (2004), sendo tudo aquilo e aquele que age na rede, humano ou não humano. Em alguns momentos da tese, o termo "tecnoator" será utilizado como sinônimo de "ator-rede", que será aprofundando mais adiante.
} 
cosmologia xamânica nos circuitos digitais da rede, o que resultou na digitalização de suas territorialidades e de suas relações.

Por sua vez, a escolha da "e-diáspora" cabila/berbere ${ }^{13}$ responde a um exemplo de digitalização de uma situação diaspórica. A característica "e-dispórica" da cultura cabila/berbere é marcada por sua concentração e reprodução em diversos países, principalmente na França, por meio do portal Kabyle.com, no qual me debrucei para a análise. Ao realizar o estágio sanduíche no exterior ${ }^{14}$, entre março e agosto de 2012, pude interagir com seus circuitos e ter acesso a uma bibliografia específica sobre esses grupos.

Em ambas as experiências reticulares selecionadas, meu campo de análise foi o estudo do papel desenvolvido pelas arquiteturas informativas digitais ${ }^{15}$ nas suas dimensões culturais e territoriais, testando algumas hipóteses que me pareceram altamente pertinentes:

1. O modelo comunicativo digital, conectivo e reticular, favorece um peculiar tipo de ação comunicativa desses grupos. Tal ação comunicativa permite a ressignificação das suas localidades para além de seus limites geográficos, apontando para um habitar tecno, informativo e ecossistêmico, formado por deslocamentos informativos, articulados pelas interações ecológicas e transorgânicas entre sujeitos, interfaces, informações e territórios. São essas interações, experiências glocais, com elementos, identificações e práticas culturais locais com repercussões globais e viceversa que ampliam as fronteiras e as noções de lugar;

2. A experiência midiática dessas coletividades, ocasionada pela digitalização, possibilita novas formas de expressão de suas identificações étnicas e, por sua vez, reflete a transformação cultural de seus contextos locais e de suas estratégias de representação de suas diferenças. Isto é, o "local digital" se expressa como a forma

\footnotetext{
${ }^{13}$ Os cabilas são povos de origem Berbere oriundos da região montanhosa da Cabília, nordeste da Argélia, com forte personalidade cultural (língua própria) e política. Há, na França, cerca de um milhão de cabilas, e, na Argélia, são três milhões e meio.

14 O estágio de Doutorado no exterior foi realizado com bolsa Capes, durante o período de $1^{\circ}$ de março a 31 de agosto de 2012, no IULM, Milão. Na Europa, tive a oportunidade de, além de pesquisar na Itália, participar de eventos científicos e fazer pesquisa bibliográfica e de campo em Paris (França).

${ }^{15}$ Referimo-nos à "arquitetura informativa digital" como qualquer plataforma de informação on-line, seja portal, site, blog, micro-blog, rede social. Em alguns momentos desta tese trataremos a expressão como sinônimo de ambiente informativo digital, ou ambiente digital.
} 
dinâmica de uma interação entre culturas, mídias digitais e territórios. Essas interações midiáticas habitativas realizadas por esses grupos parecem apontar para transformações significativas nos mecanismos tradicionais de performatização de suas identificações: há a tomada da palavra por esses grupos, traduzindo-se, por exemplo, no registro escrito e audiovisual (digital) das suas narrativas e memórias.

3. Essa dimensão indica a relação menos instrumental da mídia e das tecnologias digitais, dos suportes de informação e das interfaces comunicativas;

Portanto, minha tese é a de que o processo de digitalização de grupos (formados por referências étnicas) está circunstanciado por uma relação simbiótica, complexa, reticular e habitativa de suas especificidades culturais. Suas dimensões históricas, culturais, midiáticas digitais e territoriais interagem e se combinam conjuntamente, mas de forma particularizada, resultando naquilo que considero o "local digital das culturas".

Logo, a contribuição original desta tese decorre dessa abordagem, tendo desenvolvido meu argumento em três partes. Na primeira parte, dividida em dois capítulos, trato dos "trânsitos teóricos e metodológicos do local digital das culturas". No primeiro capítulo apresento os pressupostos teóricos, o mapa teórico em que me apoiei para dar conta das interações entre culturas, mídias digitais e territórios, pormenorizando as noções teóricas centrais desta tese. No segundo capítulo, discorro sobre os procedimentos metodológicos adotados, o percurso investigativo realizado nos circuitos imersivos, dialógicos e atópicos das/nas redes digitais, buscando, consequentemente, sublinhar a agencialidade dos objetos, das arquiteturas digitais, dos softwares e de tudo aquilo que possamos pensar como não humano e actante ${ }^{16}$ de um processo.

Na segunta parte, apresento ao leitor a análise da Rede Povos da Floresta, e um dos polos dessa Rede, o Centro Yorenka Ãtame da Associação Ashaninka Apiwtxa do rio Amônia. No terceiro capítulo, segundo a numeração precedente, apresento a história da Aliança Povos da Floresta, decorrente do movimento social dos seringueiros e dos povos indígenas da região do Acre. Descrevo os circuitos

\footnotetext{
${ }^{16}$ Termo oriundo da semiótica adotado por Bruno Latour em sua Teoria do Ator-Rede, designativo de uma agencialidade dos não humanos, actante é tudo aquilo que deixa rastro. Desdobraremos essa ideia mais adiante.
} 
informativos do site da RPF, analisando as asssociações de seus tecno-atores e do ecossistema da Floresta. No quarto capítulo, focalizo a análise do Centro Yorenka Ãtame, um dos polos de irradiação da RPF, refletindo a ecologia xamânica comunicativa dos Ashaninka e sua relação com o processo de digitalização, significando uma complexa "rede de redes" situada na tríade simbiôntica das interações reticulares entre essas culturas, suas produções midiáticas digitais e seus territórios. Nesse caso, a digitalização significou, além da disseminação dos saberes tradicionais dos Povos da Floresta, a criação de um complexo ecossistema informativo emergente (MORIN, 2011) que estende sua rica biodiversidade a uma dimensão tecno-informativa.

$\mathrm{Na}$ terceira parte, composta pelo quinto e sexto capítulos, aprofundo-me na expressão do local digital das culturas decorrentes da "e-diaspóra cabila", por meio da análise do Portal Kabyle.com. Originários dos povos berbere do norte da Argélia, estão atualmente espalhados pelo mundo e simultaneamente reunidos nas redes digitais. A digitalização proporcionou um ecossistema informativo que tornou possível a reunião, a disseminação, a tradução da cultura amazigh (berbere) nos fluxos informativos das redes digitais.

Em seguida, nas considerações finais, concluo analisando comparativamente estas experiências, traduzindo e reinterpretando-as como expressões exemplares desse local digital das culturas. Procuro, dessa forma, discernir suas semelhanças e diferenças, capazes de render novas compreensões sobre os processos locais que se deslocam e se reelaboram digitalmente pelas conectividades rizomáticas, tornando-se uma postura fértil para interpretá-las e repensá-las enquanto processos contemporâneos informativos e glocais. 
PARTE I

Trânsitos teóricos e metodológicos do local digital das culturas 


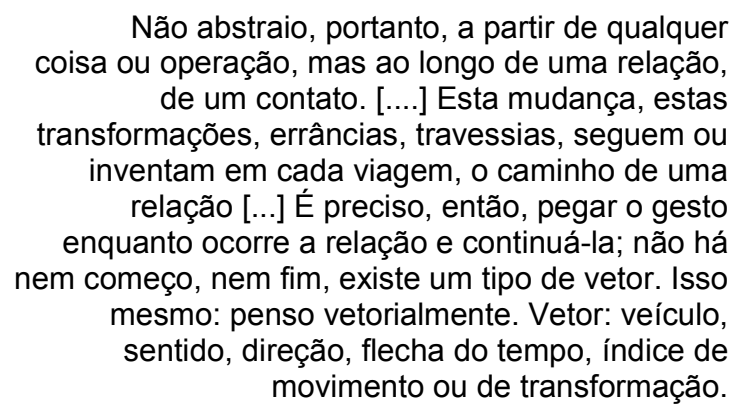

Michel Serres (1999, p. 154-155)

No interior do amplo processo de digitalização, que se caracteriza como um qualitativo fenômeno de dinamismo e de transformação sociocultural, difunde-se, em diversos contextos e por diversas modalidades, um importante processo de digitalização de grupos étnicos. Tal realidade é responsável não somente por um processo de tradução digital de saberes e culturas locais, mas, ao mesmo tempo, pela instauração de um importante processo de alteração da condição habitativa dessas culturas. De fato, ao conectar-se às redes digitais, uma comunidade expande seu território e seu ecossistema, estendendo-o por meio de um dinamismo metageográfico que o conecta a outros contextos e culturas e a outros mundos. Cria-se, assim, um complexo ecossistema que une reticularmente os grupos envolvidos, suas culturas, seus territórios, aos circuitos informativos digitais, por meio de um singular dinamismo tecno-comunicativo-habitativo.

Para realizar a análise desse campo dinâmico ocasionado pelo processo de digitalização ao estabelecer novas interações entre culturas, mídias digitais e seus territórios, apresento, nesta primeira parte desta tese, ao leitor, o mapa teórico metodológico no qual a pesquisa se desenvolveu. Composta por dois capítulos, discorro sobre os "trânsitos", esse movimento de pensar perspectivas que sublinham a relação e as confluências teóricas e metodológicas nas quais me apoiei para pensar o local digital das culturas.

No primeiro capítulo, tratei de enunciar os pressupostos teóricos nos quais a pesquisa foi elaborada, a teoria da complexidade de Edgar Morin (2011), as formas comunicativas do Habitar e a perspectiva reticular de Massimo Di Felice (2009, 2011-2012) e a Teoria Ator-Rede de Bruno Latour (2004, 2012), entre outras. As perspectivas nas quais a investigação se desenvolveu buscaram repensar, de modo epistêmico, a complexidade reticular e habitativa, assumindo uma visão ecológica 
das interações entre culturas, mídias digitais e territórios. Nesse sentido, visei estabelecer uma abordagem que considerasse essa tríade em simbiose (ou tríade simbiôntica), considerando suas relações e interações nos processos de digitalização das culturas locais.

No segundo capítulo, discorro sobre os procedimentos metodológicos adotados, o percurso investigativo realizado nos circuitos imersivos, dialógicos e atópicos das/nas redes digitais, examinando, por consequência, as arquiteturas informativas digitais e a agencialidade dos elementos humanos e não humanos nessas experiências emergentes decorrentes dos processos de digitalização das culturas locais. 


\title{
UM MAPA TEÓRICO-METODOLÓGICO ${ }^{17}$ DAS INTERAÇÕES ENTRE CULTURAS, MÍDIAS DIGITAIS E TERRITÓRIOS
}

\author{
As técnicas criam novas condições e \\ possibilitam ocasiões inesperadas para o \\ desenvolvimento das pessoas e das sociedades, \\ mas elas não determinam nem as trevas, nem a \\ iluminação para o futuro humano [...]. Que \\ tentemos compreendê-la, pois a questão não é \\ ser contra ou favor, mas sim reconhecer as \\ mudanças qualitativas na ecologia dos signos, o \\ ambiente inédito que resulta da extensão das \\ novas redes de comunicação para a vida social e \\ cultural. \\ Pierre Lévy (1999, p. 130)
}

Este primeiro capítulo trata-se dos pressupostos teórico-metodológicos orientadores da pesquisa dos quais resultaram nesta tese. Para iniciar este diálogo, permito-me inserir uma breve descrição de uma narrativa literária como oportunidade de introduzir a problemática em questão: as interações ecológicas entre culturas, mídias digitais e território do local digital das culturas.

Por meio do conto "O Espelho" (1882-1883), Machado de Assis apresenta o "esboço de uma nova teoria da alma humana". Jacobina, o personagem enunciador dessa nova teoria, narra aos seus ouvintes - quatro cavalheiros que conversam sobre especulações metafísicas num pequeno salão de uma casa no bairro de Santa Teresa (Rio de Janeiro) - a sua tese sobre existência das duas almas, uma interna e outra externa:

Se querem ouvir-me calados, posso contar-lhes um caso de minha vida, em que ressalta a mais clara demonstração acerca da matéria de que se trata. Em primeiro lugar, não há uma só alma, há duas...

- Duas?

- Nada menos de duas almas. Cada criatura humana traz duas almas consigo: uma que olha de dentro para fora, outra que olha de

\footnotetext{
${ }^{17}$ Embora neste capítulo nos detenhamos mais no aprofundamento das teorias inspiradoras da tese, mantivemos a referência "metodológica no título" porque algumas dessas teorias nos servirão de método de análise, como a Teoria Ator-Rede, de Bruno Latour, Michell Callon e John Law. A metodologia será mais bem explicitada no segundo capítulo, com o detalhamento do campo empírico e do percurso investigativo.
} 
fora para dentro... Espantem-se à vontade, podem ficar de boca aberta $[\ldots]$

[...] A alma exterior pode ser um espírito, um fluido, um homem, muitos homens, um objeto, uma operação. Há casos, por exemplo, em que um simples botão de camisa é a alma exterior de uma pessoa; - e assim também a polca, o voltarete, um livro, uma máquina, um par de botas, uma cavatina, um tambor, etc. Está claro que o ofício dessa segunda alma é transmitir a vida, como a primeira; as duas completam o homem, que é, metafisicamente falando, uma laranja. Quem perde uma das metades, perde naturalmente metade da existência; e casos há, não raros, em que a perda da alma exterior implica a da existência inteira. (ASSIS, 1995, p. 71)

Ao provocar seus ouvintes com a afirmação de sua tese, Jacobina apresenta o episódio pessoal insólito. Tinha 25 anos quando lhe foi conferida a patente de alferes da Guarda Nacional. Após tal feito, seu prestígio diante de todos da vila e da família cresceu. Era bajulado de todas as maneiras, sobretudo por sua tia Marcolina, a qual, morando num sítio a léguas da vila, providenciou que ele passasse uma temporada na sua propriedade, com a condição de que levasse também consigo a farda. No período em que com ela esteve, foi constantemente reverenciado por todos ao seu redor, emanando da forma de tratamento "senhor alferes" os cortejos à sua nova posição. Em seu quarto, a tia pôs um grande e majestoso espelho, que lhe dava a 'consciência' maior, no decorrer dos dias, da sobreposição daquela alma externa - do alferes, do sujeito social reconhecido e respeitado por todos - sobre a sua alma 'interna' e a sua 'consciência':

- O alferes eliminou o homem. Durante alguns dias as duas naturezas equilibraram-se; mas não tardou que a primitiva cedesse à outra; ficou-me uma parte mínima de humanidade. Aconteceu então que a alma exterior, que era dantes o sol, o ar, o campo, os olhos das moças, mudou de natureza, e passou a ser a cortesia e os rapapés da casa, tudo o que me falava do posto, nada do que me falava do homem. A única parte do cidadão que ficou comigo foi aquela que entendia com o exercício da patente; a outra dispersouse no ar e no passado. (ASSIS, 1995, p. 73)

Três semanas se passaram e a tia, por motivo da repentina doença terminal da filha, casada com um lavrador que vivia a léguas do sítio, partiu, deixando-o sozinho com os escravos. Estes últimos, percebendo a ausência da patroa, viram a oportunidade de escapar e ir ao encontro da liberdade. Jacobina, vendo-se só, abandonado, sentiu-se tomado pela sua alma interior, abatida, ocupada pelo silêncio e pelo vazio do passar das horas. Pela falta da sua alma exterior, dependente da 
alteridade alheia, o sono tornou-se seu refúgio. Nos sonhos, voltava a gabar-se pelos cortejos dos olhares familiares. Reencontrava-se, assim, oniricamente, com a externalidade de sua alma; do contrário, acordado, os dias pesavam-lhe pelo silêncio e pela ausência do reconhecimento desses 'Outros'. Após algumas semanas, teve a ideia de ver-se no espelho. Tinha receio, até então, de não encontrar as duas almas. De fato, ao apresentar-se diante do mesmo não se reconheceu, embora o espelho tenha refletido exatamente como era fisicamente. Decidiu, após essa primeira aproximação, vestir a farda. Após aprumar-se, viu-se, então, realizado, com as duas almas assentadas na sua imagem refletida:

O vidro reproduziu então a figura integral; nenhuma linha de menos, nenhum contorno diverso; era eu mesmo, o alferes, que achava, enfim, a alma exterior. Essa alma ausente com a dona do sítio, dispersa e fugida com os escravos, ei-la recolhida no espelho. Imaginai um homem que, pouco a pouco, emerge de um letargo, abre os olhos sem ver, depois começa a ver, distingue as pessoas dos objetos, mas não conhece individualmente uns nem outros; enfim, sabe que este é Fulano, aquele é Sicrano; aqui está uma cadeira, ali um sofá. Tudo volta ao que era antes do sono. Assim foi comigo. Olhava para o espelho, ia de um lado para outro, recuava, gesticulava, sorria e o vidro exprimia tudo. Não era mais um autômato, era um ente animado. Daí em diante, fui outro. (ASSIS, 1995, p. 80)

Finalmente Jacobina, vestido com sua farda e diante da sua imagem no espelho, reconhecia-se em sua integralidade e pôde, assim, sobreviver à solidão até que todos retornassem.

Esse conto de Machado, mais que introduzir a tese das duas almas do personagem Jacobina, pelo somatório de acontecimentos sucessivos orienta o leitor a uma reflexão sobre a composição e a consciência de si, imbricada pela interação entre os "Outros" e os objetos técnicos ${ }^{18}$. A farda de alferes e o espelho são os elementos propiciadores de uma autoconsciência, subjetividade e autopercepção construída pelo exercício da ação mútua entre o indivíduo e a "coisa”, o "objeto", a

\footnotetext{
${ }^{18}$ Enquanto objeto técnico, o espelho detém uma significação especial. Recorrentemente evocado na literatura, a imagem especular provoca, transgride, estrutura e constitui a consciência do Eu. Algumas obras são basilares: Guimarães Rosa escreveu o conto "O espelho" e Jorge Luis Borges o poema "Os espelhos", ambos publicados no ano de 1960. Do mito de Narciso aos estudos de Jacques Lacan sobre o comportamento das crianças diante do espelho, este é tomado como construtor do processo de subjetivação, não só por edificar o reflexo da imagem, mas por permitir ainda o reconhecimento da relação com a mãe, sendo também o olhar dela um espelho que se vê. Para o aprofundamento do tema por uma perspectiva psicanalítica lacaniana consultar: Vettorazzo Filho (2007, p. 130-137).
} 
"técnica", com os quais o ato de ver-se, refletir-se a si pela composição do nitrato de prata e pelo olhar dos "Outros", provoca um instante de empatia e significação do Eu.

Essa ideia de relação e interação entre os "Outros" e os objetos técnicos nos permite cotejar a conjunção entre o processo de significação de si (processo de identificação e de diferenciação) e seus aparatos técnicos/comunicativos mediadores e constitutivos. Essa relação e essa conjunção introduzem e sugerem os modos e os meios de se pensar as intersecções e as interações entre culturas, mídias e território nesse momento de difusão das redes sociais digitais.

Concebendo esses elementos teóricos como apreensões conceituais conjuntivas derivadas de suas recíprocas influências, o que pretendemos neste capítulo é apresentar a reflexão teórica com a qual esta tese dialoga e se apoia. Simultaneamente, se intenta imergir na perspectiva reticular ${ }^{19}$, um ponto perspectivo, parcial e transitivo, situada no contexto da emergência da comunicação digital e de suas relações para com as culturas e as territorialidades em que estas habitam.

Ao conjecturarmos as ligações constitutivas dos processos de identificação e diferenciação, elevadas pela expressão "culturas", e a intensificação de processos comunicativos digitais para as transformações do próprio território, por sua vez também das culturas envolvidas, tentamos extrair a singularidade dessa condição habitativa (HEIDEGGER, 1954; ABRUZZESE, 2006; DI FELICE, 2009) assumida em formas rizomáticas (DELEUZE e GUATTARI, 1995) de interpenetração, que exige um tipo de pensamento complexo, nos termos elaborados por Edgar Morin (2001, 2011). Por vivermos um forte questionamento dos paradigmas construtores do pensamento científico e no contexto da difusão das redes sociais digitais, estamos lidando com a emergência de uma complexidade reticular sem precedentes.

Dito de outra forma, nossa análise requer um conhecimento complexo, porque se elabora na intersecção, na interação, no fluxo e na troca de elementos constituintes do "local digital das culturas", da sua forma de habitar, possibilitando-

${ }^{19}$ Referimo-nos aqui à "perspectiva reticular", proposta conceitual que vem sendo desenvolvida pelo Prof. Dr. Massimo Di Felice, decorrente, principalmente, da análise das obras dos estudiosos Morin, Latour, entre outros, em conjunto com os pesquisadores do Centro de Pesquisa Atopos (ECA/USP), do qual faço parte. Dois textos lançam as bases para essa perspectiva epistêmica: "Redes digitais, epistemologias reticulares e a crise do antropomorfismo social" (DI FELICE, 20112012) e Redes digitais e sustentabilidade - as interações com o meio ambiente na era da informação (DI FELICE; TORRES; YANAZE, 2012). 
nos entrever a multiplicidade ecossistêmica de uma abordagem relacional e conjuntiva das culturas, das mídias e dos territórios.

Nosso objeto de pesquisa foi construído, portanto, nos cruzamentos e trânsitos conceituais elaborados no intuito de abstrair uma experiência amalgamada pelos circuitos informativos, complexos, fluídos, rizomáticos - permeados e constituídos por elementos viventes, orgânicos, humanos, com suas especificidades socioculturais, e não viventes, não humanos, como softwares, hardwares, objetos, matéria, ambiente ${ }^{20}$.

Em outras palavras, por problematizarmos essas interações, apresentaremos nas páginas seguintes um mapa ${ }^{21}$ teórico-metodológico, formado pelos pressupostos epistêmicos, fundamentado nas relações interativas da tríade simbiôntica (composta pelas culturas, mídias digitais e seus territórios). Tal mapa fundamentou a nossa incursão nas arquiteturas digitais interativas, nas produções multimidiáticas $^{22}$ da Rede Povos da Floresta e do Portal Kabyle.com.

\subsection{PRESSUPOSTOS EPISTÊMICOS INICIAIS}

Os pressupostos epistêmicos adotados envolvem diretamente o nosso problema de pesquisa relacionado às dinâmicas comunicativas associadas ao processo de digitalização de grupos locais como um fenômeno comunicativo glocal $^{23}$, ao mesmo tempo particular e universal, que desestabiliza o olhar do

${ }^{20}$ Compreendemos "ambiente", aqui, como toda e qualquer externalidade humana envolvente.

${ }^{21}$ Para Deleuze e Guattari $(1995$, p. 21): "Se o mapa se opõe ao decalque [imagem] é por estar inteiramente voltado para uma experimentação ancorada no real. O mapa não reproduz um inconsciente fechado sobre ele mesmo, ele o constrói. Ele contribui para a conexão dos campos, para o desbloqueio dos corpos sem órgãos, para sua abertura máxima sobre um plano de consistência. Ele faz parte do rizoma. O mapa é aberto, é conectável em todas as suas dimensões, desmontável, reversível, suscetível de receber modificações constantemente. Ele pode ser rasgado, revertido, adaptar-se a montagens de qualquer natureza, ser preparado por um indivíduo, um grupo, uma formação social. Pode-se desenhá-lo numa parede, concebê-lo como obra de arte, construí-lo como uma ação política ou como uma meditação".

${ }^{22}$ Tais arquiteturas digitais e produções multimidiáticas desenvolvidas e difundidas em e nas redes digitais serão analisadas na parte II desta tese.

${ }^{23}$ Referimos o fenômeno comunicativo glocal àquele intrínseco às redes. É local porque os pontos de vista desses grupos são veiculados e contemporaneamente global porque as redes desterritorializam suas referências culturais locais. O sociológo Roland Robertson (1999) adota o termo para designar as tendências de homogeneização e heterogeneização, aparentemente contrapostas, mas que são complementares e interpenetrantes. Robertson amplia o termo "glocal", apresentado no Oxford Dictionary of New Words (1991, p. 134), no qual o termo é mencionado 
pesquisador, reverberando nele (ou nela) uma reflexão epistêmica necessária, imbricada na complexidade.

Referimo-nos, assim, às premissas do pensamento complexo de Edgar Morin ${ }^{24}$, que favoreceram uma (pre)meditação das conjunções e intersecções das culturas, mídias e espacialidades, noções muitas vezes circunstanciadas num invólucro teórico díspar. De certo, observando a tessitura da significação, do compartilhamento e comunicação de signos, imagens e discursos, representações num nível étnico, autopercebida como diferença e marco do diverso, o ato de comunicar, de pôr em comum, somada aos seus suportes, medium, eleva e reconfigura os sentidos espaciais, imprimindo à territorialidade um referente historicamente geográfico, uma substancialidade e relatividade midiática. A não separação desses elementos irredutíveis - cultura, mídias e território - analisados como tessitura possível por um olhar transdisciplinar, vai ao encontro da própria ontologia da complexidade:

O que é complexidade? A um primeiro olhar, a complexidade é um tecido (complexus: o que é tecido junto) de constituintes heterogêneas inseparavelmente associadas: ela coloca o paradoxo do uno e do múltiplo. Num segundo momento, a complexidade é efetivamente o tecido de acontecimentos, ações, interações, retroações, determinações, acasos, que constituem nosso mundo fenomênico. (MORIN, 2011, p. 13)

Distinguir sem disjungir, associar sem reduzir, movimentos de um pensamento renunciador da simplificação e separação intrínsecas ao conhecimento científico ocidental. Essa sensibilidade epistêmica foi o eixo de toda a produção de Morin, reveladora de uma teoria da organização impregnada em seu percurso teórico assentado na cibernética, teoria da informação e teoria dos sistemas. Parte

como baseado na noção japonesa dochaku, "viver na própria terra", adoção de princípios agrícolas às condições locais. Mais tarde, nos anos 1980, o termo tornava-se jargão na área de marketing, que o disseminou referindo-se à técnica do micromarketing: "personalização e comercialização de produtos e serviços de base global ou quase global em escala local e para mercados específicos cada vez mais diferenciados" (ROBERTSON, 1999, p. 251). Robertson vai além desse sentido e se vale da ideia geral de glocalização para problematizar as dicotomias entre o local e o global. É interessante citar o comentário de uma de suas colegas japonesas, que menciona o sentido fora do uso comercial da palavra dochakuka, que se relaciona à ideia de "tornar algo indígena" (ROBERTSON, 1999, p. 252).

${ }^{24}$ Analisamos duas obras do autor que nos permitiram inferir as principais ideias de base de seu pensamento complexo: a primeira obra, Introdução ao pensamento complexo (editora Sulina, 2005); a segunda, o primeiro tomo da colossal obra O método, lida em italiano, II método - La natura della natura (Raffaello Cortina Editore, 2011 [1977]). No Brasil, os seis tomos dessa obra foram publicados também pela editora Sulina. 
da própria complexificação dos $\operatorname{organismos}^{25}$ e da concretização do sistemismo, indicador de uma necessidade de organizacionismo (oposto ao organicismo ${ }^{26}$ ), princípios comuns organizacionais de sua própria evolução característica de diversificação (MORIN, 2011, p. 28).

A abordagem organizacionista do filósofo interage diretamente com a cibernética, aprofundando-a, estabelecendo o primado da questão do fenômeno da auto-organização para a compreensão da vida. Tal ideia de auto-organização retoma paradoxo da organização viva, de Schrödinger (1945), a diferença entre máquina viva (auto-organizada) e a máquina artefato (simplesmente organizada) assim dita por Von Neuman. A ordem das coisas vivas (auto-organizadas) aplica-se a uma lógica complexa, moldada pelo "elo consubstancial", nas palavras de Morin, "entre desorganização e organização complexa", o fenômeno duplo da desorganização (entropia) e da reorganização (neguentropia) mais rápido nos organismos vivos que nas máquinas. A auto-organização, nascida da desordem e de sua reorganização, produz um efeito dinâmico de uma ontologia dos objetos, vistos, a partir dessa ótica, por uma individualidade fenomenal de sistemas vivos (orgânicos) e de máquinas artificiais (inorgânico). Existiria uma autonomia relativa característica da mesma ordem das interações com o ambiente externo, interdependência necessária, moldada pelas aberturas e trocas, um sistema autoeco-organizador:

[...] o sistema auto-organizador se destaca do meio ambiente e dele se distingue, por sua autonomia e sua individualidade, ele se liga ainda mais a este pelo aumento da abertura e da troca que acompanham todo progresso de complexidade: ele é auto-ecoorganizador. Enquanto sistema fechado não tem qualquer individualidade, nenhuma troca com o exterior, e mantém relações

${ }^{25} \mathrm{O}$ conceito de autopoiese (do grego poiesis, fazer, engendrar, criar - autofazer, autocriação), desenvolvido originalmente pelos biólogos chilenos Humberto Maturana e Francisco Varela, na obra Máquinas y seres vivos (1972), é uma referência influente na obra de Morin. Tomando por base sistemas vivos auto-organizados compostos por unidades em contato com o ambiente e dele diferenciados, Maturana e Varela (1997) propõem um tipo de Biologia do Conhecer, uma explicação da fenomenologia observada no constante vir a ser dos seres vivos, uma reflexão da linguagem e da cognição.

${ }^{26}$ É salutar a diferença estabelecida por Morin (2011, p. 28) entre os conceitos organizacionismo e organicismo, este último "sincrético, histórico, confuso, romântico". Modelo analógico de um organismo concebido como totalidade orgânica, macrocosmo, modelo organicista da sociedade humana, assim como foi pensado pela sociologia do século XIX (Herbert Spencer), rasamente, nas palavras de Morin, imbuído da equivalência entre vida biológica e vida social. Esse modelo de biologização social caracterizava os sistemas de comunicação da época como agentes do desenvolvimento e da civilização, toada de uma ideia de progresso, equilíbrio e ordem, uma filosofia da história teleológica, assumida por um modelo civilizatório ocidental. 
muito pobres com o meio ambiente, o sistema auto-eco-organizador tem sua própria individualidade ligada a relações com o meio ambiente muito ricas, portanto dependentes. Mais autônomo, ele está menos isolado. Ele necessita de alimentos, de matéria/energia, mas também de informação, de ordem (Schrödinger). O meio ambiente está de repente no interior dele e, [...] joga um papel coorganizador. O sistema auto-eco-organizador não pode pois bastarse a si mesmo, ele só pode ser totalmente lógico ao abarcar em si o ambiente externo. Ele não pode se concluir, se fechar, ser autossuficiente. (MORIN, 2011, p. 33)

Tal raciocínio se revela promissor para problematizar uma episteme simplificadora, cartesiana e positiva. Contudo, o pensamento complexo de Morin esbarra, ainda, numa diferenciação separatista organizacional dos sistemas dos organismos vivos e daqueles "artificiais" (inorgânicos). Presumido por uma interdependência ambiental, externa, esse sistema auto-eco-organizador é pensado na complexidade da coisa viva, do orgânico. Valida, se assim podemos dizer, um humanismo orgânico, pensado por um paradigma epistêmico complexo. Mesmo que tenhamos como horizonte epistêmico a concomitância de viventes e não viventes (a ser discutido mais adiante), os eixos do paradigma epistêmico de Morin são fundamentais para apontarmos a construção dos objetos de conhecimento concebidos em "seu ecossistema e mais amplamente num mundo aberto (que o conhecimento não pode preencher) e num metassistema, uma teoria a elaborar onde o sujeito e o objeto poderiam integrar-se um ao outro" (MORIN, 2011, p. 4748).

Nas palavras do filósofo francês, é um tipo de scienza nuova (como mencionado por G. Vico) em movimento, "num pensamento complexo que conecta a teoria à metodologia, à epistemologia e até mesmo à ontologia" (MORIN, 2011, p. 49). Uma teoria que pede "uma metodologia ao mesmo tempo aberta (que integre as antigas) e específica (a descrição das unidades complexas). [...] [teoria] que também prioriza as emergências, as interferências, como os fenômenos constitutivos do objeto." (MORIN, 2011, p. 48). Trata-se de pensar uma ciência que integre, em seu resultado epistêmico, o acaso, em sua face imprevisível e caracterizado no acontecimento (essa fenda na determinação e na predição) e no polidimensional da informação.

Estamos aqui retomando essa disposição complexa enquanto crítica a uma disposição epistêmica afeita à separação sujeito-objeto, favorável à multidimensionalidade e à contradição, somada aos três princípios da complexidade, 
segundo Morin. O primeiro, a dialogia - complementariedade da ordem e desordem, da organização e complexidade, a dualidade no seio da unidade. O segundo, a recursão organizacional, processo recursivo, causas, efeitos e produtos misturam-se no processo que os gera, "o produto é produtor do que o produz" (MORIN, 2011, p. 87):

\begin{abstract}
Nós, indivíduos, somos os produtores de um processo de reprodução que é anterior a nós. Mais uma vez que somos produtos, nos tornamos produtores do processo que vai continuar. [...]. A sociedade é produzida pelas interações entre indivíduos, mas a sociedade, uma vez produzida, retroage sobre os indivíduos e os produz. Se não houvesse a sociedade e sua cultura, uma linguagem, um saber adquirido, não seríamos indivíduos humanos. Ou seja, os indivíduos produzem a sociedade que produz os indivíduos. Somos ao mesmo tempo produto e produtores. A ideia recursiva é, pois, uma ideia em ruptura com a ideia linear de causa/efeito, de produto/produtor, de estrutura/superestrutura, já que tudo o que é produzido volta-se sobre o que o produz num ciclo ele mesmo autoconstitutivo, autoorganizador e autoprodutor. (MORIN, 2011, p. 74)
\end{abstract}

No terceiro e último, Morin (2011, p. 74) nos propõe o princípio hologramático - a imagem é retomada para sintetizar a sentença de que o holograma contém a "quase totalidade da informação do objeto representado", parte e todo são reciprocamente contidos. Princípio presente no mundo biológico e social, no primeiro, a unidade formada pelo DNA de nosso organismo contém a totalidade da informação genética desse mesmo organismo. Vemos aqui que não há reducionismo ou subordinação da parte pelo todo (holismo). Essa imagem holográfica aponta para outros dois princípios da complexidade, o da lógica recursiva inspirada na ideia de Pascal, "Não posso conceber o todo sem as partes e não posso conceber as partes sem o todo", à ideia da dialógica.

Ora, o pensamento complexo, para nós, é uma provocação epistêmica que traz em seu eixo constitutivo a impossibilidade de unificar, de concluir, de subtrair, é "uma parcela de incerteza, uma parcela de indecibilidade" (MORIN, 2011, p. 97) que inspira, consequentemente, a repensarmos a rede, esse plano alusivo de interações e processos cognitivos, experiências midiáticas reticulares digitais, no caso analisado, essa conjunção de apropriações, interações de grupos que se diferenciam culturalmente e suas metaterritorialidades ${ }^{27}$.

\footnotetext{
${ }^{27}$ Referimo-nos aos metaterritórios informativos à simbiose entre informação e território. Ver: Di Felice; Torres; Yanaze, 2012.
} 
Estamos aqui empreendendo, como resultado de uma interrogação situada nos estudos do habitar e da sua correlação com as redes, realizada pelo sociólogo Massimo Di Felice ${ }^{28}$, um percurso teórico perspectivo e, portanto, parcial, que encontra ressonância no esboço de uma perspectiva reticular, delineada pela necessidade de compreensão das transformações ocasionadas pela difusão das redes digitais:

Para entender a profundidade das transformações decorrentes da difusão das redes digitais é necessário interpretar a lógica reticular a partir não somente de uma perspectiva comunicativa, mas no interior de uma mudança maior que torna possível a compreensão das arquiteturas reticulares como uma ruptura epistêmica que acontece em diversos campos do conhecimento. (DI FELICE, 2011-2012, p. 9)

Segundo Di Felice (2011-2012), tais transformações reticulares têm sua origem na geometria elíptica (B. Riemann), no princípio da indeterminação e na teoria da relatividade de Einstein. A dimesão do espaço ' $n$ ', descrita por Riemann, não coaduna com a representação geométrica espacial em linhas retas paralelas. Sua multidimensionalidade articula-se, ao contrário, aos traços das linhas curvas, que, posteriormente, foi aplicado por Einstein, em sua teoria da relatividade, aos estudos dos processos de propagação da luz, tendo sido demonstrada a impossibilidade da representação linear dos espaços. Ao mesmo tempo, essa crise representacional do espaço repercutia na atenção à influência do observador no espaço por ele estudado. Nos estudos de W. Heisenberg das partículas subtômicas, mostrou-se visível a alteração da medição destas quando observadas, levando-o a considerar esse "princípio de indeterminação" como a própria imprecisão causal e seus possíveis efeitos correlacionados.

Se esses estudos no campo da física reorientaram as bases para a consideração da impossibilidade de representação espacial e a influência dos instrumentos de observação do pesquisador nos objetos por ele estudados, esses acabaram por apontar para uma lógica relacional constitutiva do próprio dinamismo oriundo da relação do sujeito (observador) e dos objetos por ele pesquisados.

Essa lógica relacional será recolocada pelos estudiosos do campo da Biologia como categorias iminentemente amplas, designativas de uma interdependência

${ }^{28}$ Estamos aqui nos referindo, principalmente, ao artigo "Redes sociais digitais, epistemologias reticulares e a crise do antropomorfismo social", publicado na Revista USP n. 92, do trimestre dez.jan.-fev. 2011-2012, p. 06-19. 
entre todos os elementos vivos e suas funções vitais e o meio ambiente. Mais precisamente, serão as categorias de ecologia ${ }^{29}$ (a ciência que se ocupa do estudo das relações entre seres vivos e ambientes) e ecossistemas ${ }^{30}$ (um todo que reúne tanto seres orgânicos, inorgânicos e ambientes, muito mais que a soma dessas partes) a enfatizar as conexões e as interdependências dos conjuntos associativos e distintos.

A conceituação dessa diversidade em escalas macro e micro interrelacionadas, seja pela troca mútua de energia de sistemas orgânicos e inorgânicos e seu ambiente, são abstrações que de alguma forma estabelecem mentalmente limites. Como tal, essa limitação foi assim observada por Arthur Tansley (1935 apud LÉVÊQUE, 2001, p. 35):

Todo o método da ciência constitui o isolamento mental dos sistemas para estudá-los, para que as séries de isolados que criamos se tornem os atuais objetos de nosso estudo, quer o isolado seja um sistema solar, um planeta, uma região climática, uma comunidade vegetal ou animal, um organismo individual, uma molécula orgânica ou um átomo. $\mathrm{Na}$ verdade, os sistemas que isolamos mentalmente não só estão incluídos como parte de outros maiores, como também se sobrepõem, engrenam e interagem entre si. O isolamento é, em parte, artificial, mas é a única forma possível de procedermos.

Esse procedimento inevitável de abstração e isolamento, nas palavras de Tansley, pode ser reavaliado na assunção de uma condição parcial de conhecimento, construído pela interação do sujeito cognoscente com o seu objeto cognoscível, mais do que na adoção consciente do 'isolamento' das partes interagentes, ponto já discutido anteriormente por meio dos princípios da complexidade adotados por Edgar Morin. O desafio é justamente buscar ultrapassar esse modus operandi de seleção e separação, ainda que seja sempre essa a

\footnotetext{
${ }^{29}$ O termo Ökologie foi elaborado pela primeira vez em 1866, pelo zoologista e biólogo alemão E. H. Haeckel (1834-1919), derivado do grego oîkos, "casa" e de logos, ou "linguagem". Seguidor das ideias de Darwin, Haeckel designou a ecologia como uma ciência voltada para o estudo das relações dos seres vivos entre si e/ou com o meio orgânico ou inorgânico no qual vivem. Posteriormente, o termo foi empregado por Abraham Moles (1920-1992) em seu projeto teórico de "ecologia da comunicação", associado ao modelo matemático de Shanon e às análises de Norbert Wiener, uma ciência da interação entre espécies diferentes de um dado campo: "[a comunicação] como a ação de fazer participar um organismo ou um sistema situado em dado ponto $R$ das experiências (Erfahrungen) e estímulos de meio de um outro indivíduo ou sistema situado em outro local e em outro tempo, utilizando os elementos de conhecimento que possuem em comum" (MOLES, 1975 apud MATTELART, 2003, p. 64-65).

${ }^{30}$ Formulado pela primeira vez pelo botânico A. Tansley, em 1935, o conceito "ecossistema" remete à ideia de sistema integrado formado por seres vivos e ambiente, suas características físico-químicas e as inter-relações entre ambos. A biosfera seria o conjunto de ecossistemas existente na Terra.
} 
obsessão da academia: pelo recorte, pela delimitação, como correção dos procedimentos e saber científicos.

Embora não pretendamos aprofundar a questão das relações ecossistêmicas, como uma percepção epistêmica, nos diversos campos disciplinares, não se pode negligenciar que na antropologia o tema dos "fatores ecológicos", homem e ambiente, assim como natureza e cultura, mesmo que muitas vezes compreendidos como o alargamento de antinomias, foram incorporados ao longo da sua constituição, prevalecendo na constituição de seus objetos ${ }^{31}$. É minimamente razoável matizar o aparecimento desses fatores para além de um 'antropocentrismo' disciplinar, veiculado à própria etimologia da palavra antropos, condicionado às vicissitudes do seu horizonte histórico, no pleno desenvolvimento dos seus objetos teóricos e empíricos. Portanto, uma abordagem ecossistêmica também foi assinalada pela disciplina nos trabalhos de autores como Julian Steward (ecologia cultural) e Roy Rapport (antropologia ecológica) ${ }^{32}$, entre outros, como o próprio Gregory Bateson e sua ecologia da mente, fundador da segunda cibernética, a ser mencionado mais adiante.

$\mathrm{Na}$ comunicação - esse campo particular das ciências sociais, marcado pela pluralidade, dispersão e tensão (Mattelart, 2003) - a abordagem ecossistêmica será iniciada nos trabalhos da segundo cibernética inspirada e crítica à primeira de Norbert Wiener $(1948)^{33}$ ao seu modelo de funcionamento e controle, circular e

31 Embora não oriunda de uma problemática antropológica, mas claramente sociológica dos processos de urbanização e migração, a Escola de Chicago tem, na proposta de Robert Ezra Parks e E. W. Burgess, os desígnios de uma ecologia humana, em uma tentativa de introdução de esquemas teóricos da ecologia vegetal e animal aos estudos das comunidades humanas. Estas últimas são definidas pela sua organização num território, cujos membros mais ou menos enraizados vivem em relações de interdependência e simbiose. As relações interindividuais constituem-se na luta pelo espaço, na competição e na divisão do trabalho. Parks, assim, analisa as relações étnicas nas comunidades imigrantes presentes nos espaços urbanos dos EUA pelo viés da competição, do conflito, da adaptação e da assimilação (a comunicação teria um papel singular de integração desses grupos). Nessa orientação teórica existe uma clara diferença entre ambiente, seus níveis simbióticos de competitividade bióticos (comunidades) e sua influência social. A produção de territorialidades na cidade, como o aparecimento de bairros com características étnicas associadas aos grupos imigratórios, era analisada numa estrutura pré-definida e estática (MATELLART, 2003).

${ }^{32}$ Ver a dissertação de Mestrado em Antropologia Social de Eduardo Di Deus, Antropologia e ambiente - entre transgressões e sínteses (Brasília, Universidade de Brasília, 2007). O antropólogo faz um estudo da trajetória da antropologia, seu debate sobre o ambiente e suas relações com a biologia, traçando uma rica e pertinente análise de obras e autores, entre eles Gregory Bateson e Tim Ingold, primando pela articulação realizada por eles entre biologia, antropologia e psicologia. A dissertação discorre a respeito do alcance das divisões e distinções na antropologia estabelecidas pelas diferentes abordagens das relações entre humanos e ambientes.

${ }^{33}$ A primeira cibernética, fundada pelo matemático e físico Norbert Wiener com a publicação da obra Cybernetics: or the control and communication in the animal and the machine (1948), marca a 
retroativo, de inserção de dados (inputs) processados segundo critérios prédefinidos, produtores de resultados (outputs) e retroação (feedback), dependente da expectativa alcançada e de como os dados finais elevariam a uma nova inserção no sistema (inputs) ${ }^{34}$.

A segunda cibernética formada pelo grupo da Escola de Palo Alto (nome da cidade ao sul de São Francisco, nos EUA), composta por linguistas, matemáticos, sociólogos, antropólogos e psicanalistas, impulsionados pelas pesquisas de Gregory Bateson $^{35}$, ratificou, de forma geral, a circularidade da comunicação, diferente do modelo linear de comunicação de Claude Shannon, apontando a necessidade de estudar a comunicação em termos de complexidade e de seus contextos múltiplos, reconhecendo o observador como parte do sistema. A comunicação, para eles, tornava-se um processo social de interações mais amplo integrado aos múltiplos modos de comportamento. Esses pesquisadores buscaram explicar uma situação global de interação sem isolar suas variáveis, mas observando seus processos relacionais:

A essência da comunicação reside em processos relacionais e interacionais (os elementos contam menos que as relações que se instauram entre eles). Todo comportamento humano possui uma valor comunicativo (as relações, que respondem e implicam mutuamente, podem ser concebidas como um vasto sistema de

proposta de uma ciência do controle das relações entre máquinas e seres vivos, baseada num modelo de sistema autorregulado de processo da informação. Wiener disseminou suas ideias em diversos seminários, construindo um campo de interlocução e difusão de sua teoria, conhecido por Círculo Cibernético, com seu ápice nos anos de 1943 a 1953, com encontros na New York Academy of Science, da Fundação Macy. Na "segunda cibernética" - termo cunhado por H. von Foerster por sugestão de Margaret Mead (DE BIASI, 2007, p. 57) - a partir do modelo circular retroativo de Wiener, Gregory Bateson e pesquisadores como Ray Birdwhistell, Erving Goffman, Paul Watzlawick, Edward Hall, entre outros, constituíram a Escola de Palo Alto, ou Colégio Invisível, pautando-se na ampliação do sistema considerado, introduzindo o observador e o contexto da observação. A comunicação torna-se um processo social de interações mais amplo, integrada aos múltiplos modos de comportamento.

${ }^{34}$ Mais do que um modelo de sistema autorregulado de processamento da informação, Wiener propunha um modelo de sociedade da informação ideal, controlável, para se evitar a entropia (desorganização do sistema). Nas palavras de Armand e Michele Mattelart (2003, p. 66), para Wiener: "A entropia essa tendência que tem a natureza a destruir o ordenado e precipitar a degradação biológica e a desordem social, constitui a ameaça fundamental. A informação, as máquinas que a tratam e as redes que ela tece são as únicas capazes de lutar contra essa tendência à entropia".

${ }^{35} \mathrm{O}$ antropólogo inglês estudou diversos temas, transitando nas áreas da antropologia, teoria dos sistemas, ecologia, cibernética, linguística, psicologia e psiquiatria. Além de inserir o observador no seu modelo comunicativo cibernético e pensar a comunicação não só como emissão de uma informação, mas estabelecimento de uma relação, Bateson desenvolveu a teoria do duplo vínculo (double bind), um distúrbio individual de apreensão do fluxo normal de comunicação. A contradição na compreensão da informação, dada a incapacidade de distinção da literalidade e da metáfora, gera fenômenos comportamentais esquizofrênicos. 
comunicação); observando a sucessão de mensagens situadas no contexto horizontal (a seqüência de mensagens sucessivas) e no contexto vertical (a relação entre os elementos e o sistema), é possível deduzir uma "lógica da comunicação". (WATZLAWICK, 1967 apud MATTELART, 2003, p. 68)

Este aspecto relacional da comunicação, enfatizado por Paul Watzlawick, parceiro de Bateson no Mental Research Institute (Palo Alto, EUA), é aprofundado por este último como um fator englobante. Bateson considera, em seus estudos sobre o ruído e os fluxos interativos, a interdependência do "sistema-ambiente reticular", aberto, de troca mútua de matéria, energia, informações com o ambiente exterior, em que a transformação será sempre a saída de um ponto de equilíbrio entre o sistema e o ambiente. Qualquer mudança neste último implica na transformação interna do sistema, recompondo-o, adaptando-o, corrigindo-o conforme seu funcionamento. Revela-se na sua argumentação que o recíproco pertencimento do observador e sistema, e seu contexto, compõem o universo vinculante a ser observado, inserido e situado no ponto de vista estabelecido pelo pesquisador $^{36}$ :

Na física e em certa medida na antropologia e em outras ciências, entre as quais em particular a história percebemos que o observador e também o teórico devem ser incluídos no sistema que são analisados. As teorias da física e as afirmações dos históricos são igualmente construções do homem e podem ser unicamente compreendidas como produtos de uma interação entre os dados e o cientista, que vive uma determinada época e em uma dada cultura. (BATESON, p. 285 apud DE BIASI, 2007, p. 59, tradução nossa)

Conforme Di Felice (2011-2012), a representação reticular desses sistemasambientes será apresentada como forma de arquitetura informativa com o advento da Internet $^{37}$ - modelo reticular (distribuído), segundo Paul Baran (1964), a render

\footnotetext{
${ }^{36}$ Como vimos, essa perspectiva não separatista do sujeito-objeto tem recorrência na epistemologia de Morin, a qual tomou a segunda cibernética como fonte referencial de suas meditações sobre a complexidade.

${ }^{37}$ A Internet teve sua origem na ARPANET (1969), rede de computadores criada pela Agência de Projetos de Pesquisa Avançados, a ARPA, ligada ao Departamento de Defesa dos Estados Unidos. No contexto da Guerra Fria, o objetivo da ARPA era estimular a pesquisa em computação interativa, capaz de desenvolver uma comunicação descentralizada e flexível, em que a informação se deslocasse sem a centralidade de um único ponto. $O$ empreendimento foi realizado por pesquisadores, matemáticos e programadores e teve o primeiro ponto de rede instalado na Universidade da Califórnia, em 1969. Em 1972, já existiam 37 universidades e organismos de pesquisas governamentais ligados à rede. Como os pacotes de informação poderiam ser transmitidos em códigos de programação, criou-se, em 1978, um protocolo de controle de
} 
uma nova e profunda transformação no arco da história humana. De receptor de processos informativos do jornal, do rádio, da TV, com a nova arquitetura informativa digital $^{38}$ reticular os sujeitos tornam-se produtores e arquitetos dos fluxos comunicativos, alterando a própria prática do ato de comunicar ao compor, criar e difundir seus próprios conteúdos e produtos. Graças à digitalização da informação, a conversão algoritmica zero e um, os bits transformaram-se em mediadores derradeiros entre humanos e máquina.

A disseminação da Internet e a comunicação em rede provocaram, evidentemente, o aparecimento de um novo cenário, em que flexibilidade e conectividade reticular interativa instigam novas reflexões, principalmente nessa fase da rede identificada de Web 2.0, associada, principalmente, às arquiteturas informativo-colaborativas: Wikipedia ${ }^{39}$ e YouTube $^{40}$, e às redes sociais digitais ${ }^{41}$ (entre elas Orkut, Facebook, Twitter, etc.).

Isso significa que, além das convergências das mídias, qualquer um com acesso à rede pode postar, colaborar ou enviar informações, estremecendo as fronteiras entre público/privado e direitos autorais. Fomenta-se, assim, o alicerce da sociedade informacional integrada por esses fluxos informativos. Da circulação imaterial do valor, elemento básico para a conformação mundial da economia, aos circuitos informativos de percepção (MCLUHAN, 1969; DE KERCKOVE, 2009) e de significação com a deslocação da matéria ${ }^{42}$. Tal processo informativo incidirá não

transmissão (TCP/IP) para padronizar a codificação dos dados pela rede. Com o crescimento da rede, em 1983, a ARPANET foi dividida em duas redes, uma que continuou sendo ARPANET, com fins de pesquisa, e a outra para uso militar, denominada MILNET. A primeira se expandiu para centros de pesquisas, universidades e instituições governamentais e comerciais e ganhou os contornos da Internet. Em 1990, a ARPANET já era obsoleta e foi retirada de circulação pelo governo dos EUA, que transferiu a administração da Internet para a National Science Foundation e, em seguida, foi encaminhada sua privatização. No mesmo ano, Tim Berners Lee construiu um programa navegador, um sistema de hipertexto - World Wide Web (www) - que, junto à abolição das restrições para os usos comerciais da Internet, iniciou o uso privado da rede.

${ }^{38}$ Referimo-nos à "arquitetura informativa digital", isto é, a qualquer plataforma de informação online, seja portal, site, blog, micro-blog, rede social.

${ }^{39}$ Enciclopédia colaborativa na Web, desenvolvida por qualquer usuário.

40 Site de vídeos aberto para armazenamento e exibição de vídeos, com direito a comentários e visualização de número de acessos.

${ }^{41}$ Não nos reportamos à expressão "mídias sociais", designativa das redes sociais digitais, utilizada principalmente pelo jargão do mundo corporativo, pois, do nosso ponto de vista, ela enfatiza o elemento social intrínseco de toda mídia e omite a especificidade daquilo que pretende referir-se: o aspecto digital e colaborativo dessa 'nova' mídia.

${ }^{42}$ Vale a menção a essa imaterialidade da informação em conformidade a um tipo de "inobjeto", segundo Villem Flusser (2006, p. 32): "Inobjetos estão penetrando a circunstância e estão empurrando os objetos rumo ao horizonte. 'Informações' é o nome de tais inobjetos. O que acabo de dizer parece besteira. Sempre havia informações no nosso mundo. E, conforme o termo 'informação', trata-se de 'formação em' objetos. Todo objeto contém informação, seja livro ou quadro, 
apenas nas relações entre as pessoas e as tecnologias, mas também entre as pessoas, as tecnologias e o meio ambiente.

Efeito e fato possíveis pela própria constituição da propagação elétrica, algo que Marshall McLuhan, na obra Understanding Media (1964), já mencionava: a eletricidade como um contexto criador de uma unidade orgânica entre os diversos processos cognitivos, midiáticos, sociais, territoriais. A plasticidade digital impulsionada pela eletrificação transforma a informação em arquiteturas interativas. Envolve, portanto, um processo vasto de coadunação de inputs e outputs informativos, algoritmos, signos, programas, suportes, dispositivos, pessoas que convergem numa inteligência coletiva (LÉVY, 2000) e conectiva (DE KERCKHOVE, 2009).

Esse contexto reforça, mais uma vez, o caráter informativo dessa arquitetura social e digital que intercede na redefinição de nosso comportamento e de nossas interações sociais, como salientado por Joshua Meyrowitz (1985), uma situação social tecnológica baseada na convergência midiática e na conectividade alcançáveis pela fruição das arquiteturas informativas reticulares, estimulando, em um nível epistêmico, a elaboração de novas perguntas quanto ao significado das redes como um problema hermenêutico. Como sublinhado por Di Felice (2011-2012, p. 13), "o processo comunicativo reticular pressupõe um experienciar uma rede, isto é, estar inside, imerso nela, tornando-se parte integrante comunicativa - um comembro.", pelo qual se modifica o processo de conhecimento.

Estudar fenômenos em e nas redes digitais é, portanto, deixar-se desafiar por processos pouco tradicionais em termos teórico-epistemológicos e metodológicos, porque somos impelidos à sua dinamicidade, sendo parte delas. Somos fortemente afetados por elas, interagimos com suas dinâmicas e ubiquidades, deslocando qualquer pretensão de frontalidade e externalidade com os objetos construídos por essas relações.

Por suas especificidades, não há amostra representável, a rede é tão extensa quanto possamos imaginar, suas entradas e saídas são tão imprevisíveis quanto.

seja lata ou garrafa. Para trazer a informação à tona, basta decifrar o objeto. Nada de novo, portanto. Como acontece sempre, tal objeção do senso comum, aparentemente razoável, é falsa. As informações atuais que penetram a nossa circunstância para desalojar os objetos são de tipo novo. As imagens eletrônicas nas telas de TV, os dados contidos em computadores, os microfilmes e hologramas e todos estes programas e modelos são a tal ponto 'moles' (software) que escapam entre os dedos. São 'inconcebíveis' no significado literal do termo. É erro chamá-los 'objetos'. São inobjetos.". 
Mas a despeito de tentar estudá-la pelas categorias sistêmicas, holísticas ou negativa, sob uma teoria crítica da indústria cultural ou da ideologia de um novo Império, a interpretação da qual experimentamos foi investigá-la enquanto uma forma de habitar. Compreendo, assim, a digitalização da interação entre sujeitos, tecnologias comunicativas e ambiente.

Dito de outra forma, ao refletirmos sobre a localidade produzida por meio das interações midiáticas realizadas pelos grupos locais, buscamos analisar as dinâmicas culturais da digitalização desses coletivos, relacionadas às formas comunicativas do habitar (HEIDEGGER, 1954; ABRUZZESE, 2006; DI FELICE, 2009).

Referimo-nos, primeiramente, ao habitar, segundo o filósofo Martin Heidegger, em suas interrogações sobre a essência da técnica, em seu ensaio, $A$ questão da técnica (1953), segundo as interpretações de Gianni Vattimo (1985) e Manuel Olasagasti (1967). Para Heidegger, a técnica implica em vontade de poder, na verdade do Ser e em seu ocultamento. Nesse caso, sua essência consiste em ambiguidade, pois, ao mesmo tempo em que a essência da técnica revela o Ser, ela também o oculta (Vattimo, 1985). O homem provoca e é provocado pela técnica. A técnica como forma de desocultamento (aletheia) e em sua etmologia grega tékhne pertence ao âmbito do produzir (poiesis). Mas que no sentido da técnica moderna, esse "descobrir", "desocultar" transforma-se numa provocação, um desafio à natureza. (OLASAGASTI, 19967, p. 123).

Embora essas interrogações de Heidegger sobre a técnica se refiram à técnica moderna, elas podem ajudar a refletir sobre a relação entre as novas tecnologias digitais e o habitar, já que, segundo o filósofo alemão, a técnica está profundamente enraizada no modo de ser do homem. Não haveria técnica sem homem e seguramente não haveria homem sem técnica. A técnica não pode ser reduzida aos instrumentos que estão disponíveis aos fins do homem.

$\mathrm{Na}$ conferência "A coisa", Heidegger (1950) interroga o que é a coisa, exemplificando sua reflexão por meio do exemplo de uma jarra, usando-a para destacar tudo que há nela: terra e céu, homens e deuses. Antes, interroga-se sobre a coseidade da coisa. A coisa existe por si porque foi produzida, e não porque a representamos. A coisa, para Heidegger, é a reunião enquanto lugar de encontro dos quatro (quarteto): terra, céu, mortais, deuses; como em um jogo de espelhos, "cada um é próprio, é o que é, mantém a sua identidade, em referência aos três" 
(HEIDEGGER apud OLASAGASTI, 1967, p. 180, tradução minha). Os jogos de espelhos da metáfora do quarteto como mundo.

Em sua conferência "Edificar, habitar, pensar", Heidegger (1951) aprofunda a ideia das coisas e do habitar como Ser do homem. Para o homem, Ser é habitar. Habitar é como os mortais estão na terra. Habitar assume, para Heidegger, toda a sua amplitude: "Habitar é habitar 'sobre a terra'. Mas 'sobre a terra' significa 'sob o céu'. E ambas relações implicam, por sua vez, 'permanecer diante dos deuses' e 'estar com os homens': a unidade original dos 'quatro'" (HEIDEGGER apud OLASAGASTI, 1988, p. 182). O quarteto é o mundo e o lugar do Ser, o lugar de sua aparição.

Nesse sentido, no ensaio "Sobre o problema do ser", Heidegger (1955) escreve a palavra ser com um X em cima: "os quatro âmbitos do quarteto e sua reunião no lugar do X" (HEIDEGGER, 1994, p. 97). O ser se dilui no quarteto e o Ser dos mortais é um Ser habitando, é um "habitar no quarteto" (HEIDEGGER, 1994, p. 98), a "quadratura". O sentido concreto está onde se tocam os quatro elementos da quadratura: "Cada um 'sobre' o outro enquanto o vela, protege, oculta" (HEIDEGGER, 1994, p. 99). Os mortais "são" ao abrir espaços com seu estar junto às coisas e aos lugares.

Pensar as transformações midiáticas da localidade é reintegrar esse sentido heideggeriano. O Ser - 'sendo', em devir - que significa habitar na metáfora do encontro do quarteto (terra, deuses, coisas e mortais) que não se separa. Nesse jogo relacional em que cada um constitui o outro, pode-se considerar a tecnologia, mais ainda na sua forma digital, como algo real e presente no Ser, inspirado naquilo que o filósofo alemão considera sobre a técnica não como um instrumento, mas como uma interrogação filosófica, em que o próprio Ser é composto pela técnica. A saber, o Ser, para Heidegger, embora seja interrogado por instrumentos metafísicos, não é ontológico, não existe enquanto tal, mas se constitui no tempo e no habitar com e entre as coisas. Pode-se considerar que esse local digital das culturas é um habitar, é um modo de ser.

Um modo de ser comunicativo, diria Alberto Abruzzese, produzido pelo imaginário dos produtos culturais dos mass media. Para o sociólogo (2006, p. 51), "habitar" é viver num "mundo habitado pela mídia", em que os seres das narrativas midiáticas (televisivas, literárias, etc.) passam a constituir o imaginário coletivo. Mais do que isso, todos os traumas, os desejos e os conflitos da sociedade habitam as 
mídias, fazem delas sua realidade imaginária coletiva. Um exemplo de estudo dessa complexidade da condição habitativa midiática, nos apresentou o sociólogo Waldenyr Caldas (1995), no qual expressou a interação entre as mudanças das arquiteturas sonoras da canção da música popular brasileira e as transformações das paisagens urbanas da cidade de São Paulo.

Além de analisar essa especificidade midiática do habitar, formada por imaginários coletivos, citada por Abruzzese e Caldas, o sociólogo Massimo Di Felice traduz o habitar heideggeriano ao compreender a relação dos sujeitos com seu território como mediada pelas tecnologias digitais - como modo de estar no mundo, forma comunicativa do habitar, prática de interação com um ambiente pósgeográfico, capaz de produzir deslocamentos informativos:

\begin{abstract}
Uma vez reproduzido digitalmente o espaço, transformado o mesmo em informação, configura-se a formação de um habitar informativo, pós-arquitetônico e pós-geográfico que, multiplicando os significados e as práticas de interações com o ambiente, nos conduz a habitar naturezas diferentes e mundos no interior dos quais nos deslocamos informaticamente. (DI FELICE, 2009, p. 22)
\end{abstract}

Essa análise do habitar como prática comunicativa, proposta por Di Felice (2009), ressignifica as implicações das tecnologias comunicativas na construção de espacialidades, qualificadas a partir das relações entre sujeitos, tecnologia e território: o habitar empático (o sujeito projeta-se sobre o espaço, transformando o texto em arquitetura), o habitar exotópico (ao contrário, o espaço eletrificado é externo ao sujeito e de lá ocorrem as transformações espaciais independente dele) e o habitar atópico (uma vez que o espaço é digitalizado, há a interação entre sujeito e ambiente e há a deslocação transorgânica e informativa do mesmo).

Tal sentido de localidade, tecnológico e produtor de imaginários nos faz repensar as manipulações tecnológicas do espaço, em que a prática comunicativa do habitar não é mais externa ao sujeito, mas se insere no processo comunicativo e tecnológico que altera suas percepções (DI FELICE, 2009, p. 298-299), um devir do sentir conceituado pelo sociólogo como "atopia": "não como um 'não lugar', mas como outro ecossistema, construído pelas interações férteis de tecnologias informativas, territorialidades e vidas, que advém dos fluxos de arquiteturas informativas distribuídas por peles sem natureza." (DI FELICE, 2009, p. 298-299). 
Nesse sentido, a noção comunicativa do habitar atópico e a adoção de uma perspectiva reticular nos orientam a refletir o processo de transformação da localidade por meio da simbiose entre mídia e ambiente, bem como a dimensão ecossistêmica do social reticular,

uma vez que a se digitalizar e a se constituir em redes, não são apenas os fluxos informativos trocados entre os humanos, mas o contexto inteiro [...] o território e o meio ambiente, criando, dessa forma, um processo reticular deslocativo e ecossistêmico, cuja análise ainda deve ser considerada. (DI FELICE, 2011-2012, p. 17)

Se estamos tratando de processos ecossistêmicos informativos, modulados pelas arquiteturas interativas dinâmicas, nos quais estamos imersos, consideramolos mais que um apanhado cognoscível de relações informativas humanas, mas um social tecnológico midiático informativo formado também por elementos não humanos (objetos, softwares, hardwares, animais, plantas, ambiente, etc.).

Estamos diante, portanto, de um novo tipo de ecologia comunicativa ${ }^{43}$ do social regida pelos ecossistemas informativos reticulares, seus processos de conectividade e territorialidade, e suas relações entre humanos e não humanos.

Esse "social", como tencionado pelo filósofo, antropólogo e sociólogo Bruno Latour $^{44}$, não é codificado por uma coisa homogênea autoexplicativa de um todo "social" enigmático e restritivamente "humano", ao contrário, sua acepção, proposta por ele, designa, nesse mesmo vocábulo, "uma série de associações entre elementos heterogêneos" e "um tipo de conexão entre coisas que não são, em si mesmas, sociais" (LATOUR, 2012, p. 23). A própria sociologia é por ele ressignificada como a "busca de associações", fazendo com que esse social resplandeça num particular movimento de reassociação e reagregação de objetos,

${ }^{43}$ Referimos, portanto, a ecologia da comunicação associada às relações entre culturas locais, redes sociais digitais e território. Como citado na nota 24 , a "ecologia da comunicação" foi debatida por Moles (1975 apud Mattelard 2003) a partir de um modelo matemático de interação entre espécies diferentes de um dado campo. Santaella (2010) também chama de "ecologia pluralista da comunicação" tomando a 'ecologia' como metáfora eficaz para se pensar as novas relações propiciadas pela revolução digital (a emergência das redes digitais e mídias locativas) nas esferas da vida social e psíquica.

44 Por nos fornecer uma importante sistematização de sua Teoria Ator-Rede, nos referimos, principalmente, à obra de Bruno Latour, Reagregando o social - uma introdução à teoria do AtorRede, traduzida e publicada em português em 2012 pelas editoras EDUFBA e EDUSC. 
$\operatorname{coletivos}^{45}$, congregando numa abordagem que tenta superar a oposição entre ator e sistema, agente e estrutura.

Nessa rearticulação, a Teoria do Ator-Rede, elaborada por Bruno Latour e seus colegas Michel Callon e John Law, entrevê a observação das práticas sociais, no decorrer da construção do fato científico ${ }^{46}$, antes de sua estabilização e consenso, partindo de uma rede de conexões heterogêneas de atores, humanos e não humanos, actantes ${ }^{47}$, termo emprestado da semiótica referente a qualquer um que deixe rastro ou efeito. Distinguem-se, então, as interações (a serem analisadas pelas suas associações) da intencionalidade (produzida por atores envolvidos no campo de análise). Em outras palavras, não é a intencionalidade dos atores (humanos ou não) a ser investigada, mas suas relações, associações e conexões.

Dessa forma, pretendemos, com esta tese, apreender as interações emergentes produzidas pela combinação dos grupos locais (particularmente a performance $^{48}$ das suas identificações e dos processos de diferenciação) e de suas culturas, as arquiteturas informativas digitais (as produções midiáticas desses grupos, como sites, blogs, etc.) e suas territorialidades. Tais elementos serão (de um ponto de vista simplificador, identificados por 'culturas', 'mídias' e 'territórios'), ao

${ }^{45} \mathrm{O}$ termo coletivo é bastante preciso na teoria de Bruno Latour (2004, p. 373), referindo-se a um tipo de procedimento de coligar as associações entre humanos e não humanos, uma expressão de uma ecologia política, de uma política da natureza, pela qual a sociedade, entendida por seus coletivos, não separa natureza e cultura ou natureza e sociedade da análise sobre o fenômeno social.

${ }^{46} \mathrm{O}$ campo de interesse de Bruno Latour, dado as pesquisas realizadas, volta-se à produção dos fatos científicos antes de que estes se tornem "fatos". Envolvem, portanto, as ciências, suas controvérsias, disputas, situadas nas diversas áreas do conhecimento, da biologia, economia, direito, política, sociologia, pela cartografia das controvérsias, do rastreamento das associações e relações dos diversos atores envolvidos, humanos e não humanos. Reapropriamo-nos dessa perspectiva não antropocêntrica da Teoria Ator-Rede para analisar os agenciamentos das práticas comunicativas das arquiteturas informativas digitais dos grupos locais estudados. Não realizamos, portanto, uma "cartografia das controvérsias", anterior aos "fatos científicos", mas estamos mais próximos daquilo que ele propõe, de rastrear as conexões entre os diversos tecno-atores ou atoresredes, no nosso caso, "visíveis" e "realizadas" por meios das interações e práticas comunicativas a partir das arquiteturas informativas.

${ }_{47}$ Termo oriundo da semiótica introduzido por Greimas (1966) adotado por Bruno Latour em sua Teoria do Ator-Rede, designativo de uma agencialidade dos não humanos, actante é tudo aquilo que deixa rastro. Esse conceito teórico e operatório introduzido por Greimas no domínio da narratologia trata-se de "uma reinterpretação linguística da dramatis personae, reinterpretação essa baseada na sintaxe estrutural de L. Tesnière. Para Tesnière "os actantes são os seres ou as coisas que de algum modo, mesmo a título de simples figurantes e da forma mais passiva, participam do processo" (TESNIĖRE, 1965, p. 102). (...) O actante pode objetivar-se, ao nível da manifestação discursiva, por uma série de entidades suscetíveis de individuação, os atores $(v$,$) -$ seres humanos, animais, objetos, conceitos, valores morais" (REIS E LOPES, 1988, p. 145)

${ }^{48}$ Compreendemos performances identitárias como acontecimento, ato de expressão de identidades situadas e reconhecidas em seus contextos. Analisaremos essas performances, sobretudo, nos conteúdos enunciados nas arquiteturas informativas digitais, nas suas mais diversas linguagens midiáticas (textual, fotográfica e audiovisual). 
longo da tese, diluídos por suas vinculações, estabelecidos e delineados por suas associações. Descrevemos, assim, essas relações, e não "os grupos", "a cultura", "as mídias" e "os territórios".

Dito isso, vale ressaltar que, pela sua especificidade, a Teoria Ator-Rede de Latour, Callon e Law nos é inspiradora mais pelo teor metodológico de suas proposições do que por sua teoria, já que os mesmos reafirmam, ao longo de suas publicações, que a TAR é um método. Nas palavras de Tommasso Venturini (2008, p. 6$)^{49}$, ela assume a característica de uma "meta-metodologia", capaz de acolher e de pôr em relação diversos métodos, promovendo uma "promiscuidade metodológica" que serve para encorajar a expressão dos diversos atores:

A ANT não é uma teoria do social, não mais de quanto seja uma
teoria do sujeito ou uma teoria de Deus ou uma teoria da natureza. É
uma teoria do espaço e dos fluídos que circulam em uma situação
não-moderna. (LATOUR, 2012, p. 15, tradução nossa)

A abordagem ANT não é uma teoria. Frequentemente as teorias tentam explicar porque alguma coisa tem lugar, mas a ANT é mais descritiva que explicativa, o que significa que é uma desilusão para aqueles que buscam explicações fortes (LAW, 2007 apud VENTURINI, 2008, p. 6, tradução nossa)

Essa teoria/metodologia que busca associar simetricamente humanos e não humanos está na base da ecologia política proposta por Latour. Sua reformulação radical da ecologia política nos termos de um novo estatuto para as políticas da natureza considera, assim, a junção da compreensão de fenômenos naturais com àqueles da sociedade. Uma crítica ao modo como o Ocidente concebeu historicamente a natureza fora das questões sociais e políticas. Propõe, portanto, abarcar as entidades do coletivo e fazê-las falar pela sua articulação, buscando uma explicação do social conjunta e simétrica: "Quem se reúne, quem fala, quem decide em ecologia política? Conhecemos agora a resposta: nem a natureza, nem os humanos, mas os seres bem articulados, as associações de humanos e não humanos". (LATOUR, 2004, p. 157)

Ao buscar descrever os processos de digitalização envolvendo os grupos locais, suas produções midiáticas e seus territórios, nos parece oportuna essa

\footnotetext{
${ }^{49}$ Tomasso Venturi é sociólogo, engenheiro em comunicação, pesquisador e colega de Bruno Latour no MediaLab, Science Pó (Paris), onde é assistente do curso de graduação dirigido por Latour "Cartografia das controvérsias". No período do estágio sanduíche tive a oportunidade de conhecê-lo pessoalmente e pude assistir às apresentações dos trabalhos finais de três grupos de alunos.
} 
estratégia metodológica que envolve, consequentemente, uma sensibilidade epistêmica complexa, perspectiva e dialógica, capaz de associar esse fenômeno reticular e informativo glocal.

\subsection{TRÍADE SIMBIÔNTICA: CULTURAS, MÍDIAS DIGITAIS E TERRITÓRIOS}

A perspectiva que buscamos durante a pesquisa primou por repensar de modo epistêmico essa complexidade reticular e habitativa, assumindo uma visão ecológica das interações entre humanos, culturas, mídias, tecnologias, territórios, espacialidades, associada às suas relações. É certo que estamos diante de um terreno que já vem sendo cultivado nos últimos tempos, principalmente pelo binômico Mídias e Culturas, nos Estudos Culturais ${ }^{50}$, pelas vias mais diversas, dos estudos de recepção às práticas de consumo. Não por acaso que Mídias e cultura e/ou comunicação e cultura, além de constituírem linhas de pesquisa em diversos programas de pós-graduação em comunicação no Brasil, inclusive a que se insere esta tese, são recorrentemente tematizadas nos estudos do campo comunicacional.

Para apresentar àquilo que chamo de tríade simbiôntica formada pelas interações entre "culturas", "mídias digitais" e "territórios" apresento, em seguida, a

\footnotetext{
${ }^{50}$ Os estudos culturais nascem do esforço de se investigar a cultura de massa de forma oposta às abordagens até então realizadas pelos estudos da comunicação de massa. Oriundos do movimento britânico e americano (estadunidense e latino-americano), os Cutural Studies analisam a cultura midiática como toda produção de sentido, associada às estruturas sociais e aos contextos históricos, vinculada à problemática do poder. Propõem o estudo da cultura popular, distinto do viés elitista da indústria cultural, ao apontar o consumo da comunicação de massa como um lugar de negociação, atribuindo enorme importância à abordagem qualitativa, reunindo a tradição literária, etnográfica e a observação participante (MAIGRET, 2010, p. 223), mostrando, assim, a riqueza das práticas dos públicos. Os estudos culturais têm sua origem nos trabalhos de Richard Hoggart, fundador do Centre for Contemporary Cultural Studies (CCCS) - Universidade de Birminghan - e de Raymond Williams. Ambos oriundos da classe operária inglesa, ascenderam socialmente por meio dos incentivos e de bolsas de estudos e traduziram, em suas obras, a complexidade da cultura popular inglesa na recepção de produtos da comunicação de massa. Vale mencionar sua repercussão nos Estados Unidos, onde foram disseminados como uma reestruturação disciplinar, oposta ao poder de uma elite branca educada. Os estudos culturais foram absolvidos pelas minorias sociais (homossexuais e mulheres) e étnicas: afro-americanos, americanos de origem asiática, originando novas ramificações: Gay studies (Richard Dyer) e Women's Studies (Angela McRobbie e Charlotte Brunsdon). Evidentemente, essa repercussão maior nas minorias étnicas e sexuais gerou também novos objetos de estudo, relacionados aos estudos da produção comunicativa estadunidense: da pornografia, das práticas corporais marginais; dos estudos de séries televisivas aos videogames. Na América Latina, o agenciamento midiático e político da cultura popular é o principal tema dos trabalhos de Jesus Martin Barbero e Nestor G. Canclini, ambos seus representantes mais destacados.
} 
forma como cada uma dessas noções correlacionadas foi redimensionada para pensarmos a nossa problemática.

1.2.1. Cultura: produção comunicativa de significados e horizonte hibridizante

A noção de cultura na acepção antropológica designa um sistema simbólico de significação, "um padrão de significados transmitido historicamente, incorporado em símbolos, um sistema de concepções herdadas expressas em formas simbólicas por meio das quais os homens comunicam, perpetuam e desenvolvem seu conhecimento e suas atividades em relação à vida”. (Geertz, 1978, p. 103).

Envolve, portanto, um processo dinâmico de significação, que nos referimos consequentemente às formas de percepção do mundo e à produção de diferenças (de identidades e identificações étnicas) por meio das linguagens midiáticas. Ou seja, consideramos a cultura como noção, categoria conceitual conscientemente genérica, que informa ao mesmo a sua complexidade e a sua ligação com as tecnologias da informação e comunicação e com outras materialidades inorgânicas. Nesse sentido, essa noção aponta para uma fenomenologia comunicativa, dado que "os fenômenos culturais só funcionam culturalmente porque são também fenômenos comunicativos" (SANTAELLA, 2003, p. 29).

Ao pensarmos a cultura em seu aspecto fenomenológico, prática comunicativa do simbólico com as alteridades não humanas, nos referimos à reflexão proposta pelo antropólogo Arjun Appadurai (2001), ao pensá-la enquanto substancialidade local e dinâmica, manifestada por suas diferenças interativas e instáveis no tempo. De antemão, Appadurai prefere sua expressão adjetivada, ao invés do substantivo "cultura", qualificando, portanto, a diferença, sua propriedade mais contrastiva e menos substantiva. Um lugar de diferenças situadas, conforme também a reflexão do crítico cultural Homi Bhabha (2003), ao considerá-la como verbo, e não substantivo, algo híbrido, dinâmico, transnacional e tradutório.

Nesse sentido, "cultura" qualifica a expressão das diferenças e os processos de tradução responsáveis por novos significados para símbolos culturais. Nos processos comunicativos midiáticos, essa realização da expressão das diferenças 
acontece mediante a mobilização de sinais distintivos e contrastivos por meio da performatização das identidades.

Pensando a cultura como uma dimensão de fenômenos que acompanham uma diferença situada (APPADURAI, 2001, p. 28-29), consideramos "culturais" (adjetivadas e no plural) as diferenças que formam a base para a mobilização de identidades de grupo, e nos valemos no seu sentido polissêmico, para designar a sua objetivação em identidades étnicas e atribuições nativas (expressões autorreferenciais utilizadas pelos grupos locais a serem analisados). Expressa dessa maneira, a posição de sujeitos, segundo a elaboração do crítico cultural Stuart Hall (1998, 2003), em identidades étnicas situadas, deslizantes, próximas à noção de différance de J. Derrida, identidades nem binárias, nem naturais e nem essencializadas, mas deslocadas, de passagem, com significados posicionais e relacionais.

Esse modo de objetivar a cultura em identidades tem na etnicidade sua expressão máxima, ao compor o repertório dos elementos culturais atribuíveis pelos indivíduos de determinados grupos culturalmente diferenciados, tornando-se os instrumentos pelos quais são reivindicados direitos sociais, políticos e jurídicos. Vislumbram-se em seus aparatos discursivos todo um esforço de significação de diferenças em categorias de pertença, que estão constantemente em processos de transformação.

Seguindo as contribuições da etnicidade como sistema cultural, apontadas por Philippe Poutignat e Jocelyne Streiff-Fernant, contrárias à cultura como uma entidade totalizadora ou um conjunto de traços descritíveis indispostos às mudanças no tempo, atribuímos à nossa análise a categoria de grupos étnicos não por sua existência a priori, mas como um conjunto variável de categorias étnicas orientadoras de comportamentos, percepções e sensibilidades entre as pessoas. Tais categorias encontram-se em em constante interação com seus contextos sociais e ambientais (humano/não humano, orgânico/inorgânico), manipuladas ${ }^{51}$ por seus atores de acordo com as interações vivenciadas e predispostas a jogos de

\footnotetext{
${ }^{51}$ A saber, o modo pelo qual compreendemos essa manipulação não é resultado da ação unicamente humana no processo de interação. O processo de comunicação, a recíproca ação humana e não humana nos processos de interação nos leva a entender a manipulação das identidades étnicas num nível mais complexo de atuação conjunta dos elementos midiáticos, como aquele especular, de Jacobina, personagem de Machado de Assis, do conto "O Espelho", como mencionado anteriormente. Quem age no sentido de devolver à consciência de Jacobina a sua dupla alma (sua identidade)? A ação de Jacobina? Do espelho? De sua roupa? Optamos por empreender a suspeição de uma única ação e entrevê-la na sua simbiose.
} 
linguagens específicos, compartilhados por esses contextos simbólicos, midiáticos e digitais.

Nesse horizonte de reflexão, a concepção de etnicidade de F. Barth é bastante pertinente, tomada como uma forma de interação social interdependente, a existência de grupos étnicos depende da manutenção de suas fronteiras sociais: "de que modo a dicotomização entre membros e outsiders são produzidas e mantidas" (POUTIGNAT e STREIFF-FENART, 1998, p. 112), moduladas por categorias de autopertencimento (autoatribuição):

Concentrando-se naquilo que é socialmente efetivo, os grupos étnicos são vistos como uma forma de organização social. Então, um traço fundamental torna-se, [...], a característica da auto-atribuição ou da atribuição por outros a uma categoria étnica. Uma atribuição categórica é uma atribuição étnica quando classifica uma pessoa em termos de sua identidade básica mais geral, presumivelmente determinada por sua origem e seu meio ambiente. Na medida em que os atores usam identidades étnicas para categorizar a si mesmos e outros, com objetivos de interação, eles formam grupos étnicos no sentido organizacional. (BARTH, 1969, p. 193-194)

Muda-se, assim, o foco da análise, do conteúdo dessa diferença, pelo modo como são estabelecidas essas diferenças no decorrer de suas interações, negociações e posições orientadas, segundo o contraste com outros grupos, pelo modo também como são comunicadas, por seus aparatos técnicos e midiáticos. A construção da percepção de uma identidade pessoal e social da pessoa ${ }^{52}$, intrinsecamente conectadas, dimensões de um mesmo fenômeno, acontece pela instauração dos processos comunicativos e estes, por sua vez, pelas relações estabelecidas não só entre humanos, mas entre os objetos técnicos, como vimos anteriormente, num nível epistêmico, e, também, pelos midiáticos.

Esse modo de pertencimento social e identitário midiático é adotado pelo filósofo e colega, Andre Stangl (2004), ao propor o e-tnicidade. Discorrendo, dessa forma, sobre a e-tnia, enquanto diálogo e sentido coletivo de pertencimento engendrado no ambiente informacional e digital da Internet. Para ele, a etnia e e-tnia diferem-se porque no ciberespaço o fenótipo é o discurso tomado em suas últimas consequências, uma nova reconfiguração da identidade cultural, a expansão do diálogo entre culturas, não limitado ao espaço geográfico, sendo as fronteiras

\footnotetext{
${ }^{52}$ Reportamo-nos, aqui, à concepção de "pessoa" (como persona, máscara) designada por Maffesoli.
} 
nossos próprios discursos (STANGL, 2004, p. 82). Com as redes digitais, e seus novos espaços de comunicação, pode haver, numa perspectiva futura, a superação do discurso de pertencimento com a expansão do diálogo, de modo a hibridizar essas diferenças. Essa nova etnicidade, para Stangl, é fruto dessa nova identidade que se assume na rede, bem como das transformações da própria cultura.

Essa é uma interpretação possível, mas, nesta tese, tomaremos a manifestação de identidades étnicas presentes nos discursos enquanto práticas tecnossociais de diferenciação e subjetivação relacionados aos seus territórios. Analisaremos, particularmente, as atribuições e os pertencimentos étnicos nas produções midiáticas digitais das arquiteturas informativas digitais (redes sociais, sites, vídeos, etc.) e suas relações espaciais. Nosso olhar está situado, portanto, na tríade: nas relações entre as culturas (suas identidades e identificações), suas produções midiáticas digitais e seus metaterritórios, e como estes elementos interagem e se combinam.

Para isso, propomos ultrapassar as leituras "antropocêntricas" relacionadas aos processos culturais e identitários. Isto é, os processos comunicativos quantos os ditos culturais são analisados sistematicamente pela centralidade do humano como o agente único e absoluto das transformações. Revelam-se, assim, a recorrência das antinomias natureza/cultura e humanos/técnicas baseadas fortemente num antropocentrismo, paradigma que vem sendo questionado pelos teóricos póshumanistas ${ }^{53}$, entre os quais o biólogo Robert Marchesini, autor do elucidativo texto "Contra a pureza essencialista, rumo a novos modelos de existência” (2010).

\footnotetext{
${ }^{53}$ Há uma vasta literatura sobre as teorias do pós-humanismo, voltadas à crítica ao humanismo como referente epistêmico absoluto do humano sobre aquilo que lhe é externo. Lúcia Santaella menciona a carta sobre o humanismo de Heidegger, como uma referência crucial na qual o filósofo alemão expôs a crise do humanismo clássico e a necessidade de um trans-humanismo. Seus argumentos para este texto, escrito em 1946, nascem como resposta a uma pergunta de Jean Beaufret, de como dar sentido novamente à palavra humanismo, após a Segunda Guerra Mundial e às voltas da crise europeia do pós-guerra. Brevemente, Heidegger lança-se numa perspectiva histórica do humanismo, dos romanos na sua distinção de humano em relação aos bárbaros. O humanismo é tributário de sua herança helênica e será matizado nos séculos seguintes, ainda com suas diferenças, sob bases comuns de um entendimento 'humano' sobre a natureza, a história, sob um fundamento comum de domínio da racionalidade humana, ou, em suas palavras, de uma metafísica. É essa a essência da crítica de Heidegger sobre o humanismo; até então, suas bases são fundamentadas numa humanidade que não pode ser pensada por qualquer metafísica. Nas palavras de Santaella (2010, p. 109), o pós-humanismo de Heidegger é um humanismo extremado porque parte da "cercania do ser, do ec-estático habitar na cercania do ser". Nos rastros de Heidegger, indo mais longe e contra, ao pensar o pós-humanismo, diante das transformações biotecnológicas e, porque não dizer, das desgraças que o homem criou no mundo, Peter Sloterdijk, sintetizado aqui, perscruta que o humanismo sempre se definiu numa oposição ao barbarismo, associado à própria expansão da alfabetização e do letramento no curso da história ocidental, buscando, em certa medida, que as tendências embrutecedoras do humano pudessem ser
} 
É por esse artigo que teremos a oportunidade de introduzir a tríade simbiôntica (grosso modo, a simbiose entre culturas, mídias e territórios), a nossa segunda configuração tecno-informativa, como uma crítica à centralidade do humano e à sujeição instrumental da técnica, aproximando-a ao questionamento realizado pelos teóricos pós-humanistas.

Valemo-nos dos argumentos de Marchesini para sublinharmos as inconsistências das revogadas separações, criadoras de obstáculos epistemológicos, nos termos de Gaston Bachelard que, segundo o biólogo, impedem a percepção de uma hibridação do humano fundamentado em suas características neurobiológicas, filogenéticas e contingentes, associadas aos processos de aprendizagem. Somos seres imaturos quando nascemos, com idade evolutiva prolongada, dependentes das interações com o meio externo para nos desenvolvermos, desde a nossa caixa crânica - que continua a expandir-se após o nascimento - aos nossos sistemas neurais. O determinismo biológico ou aquele cultural perde potência ao pensarmos, principalmente, a dimensão epimelêtica da natureza humana, a qual Marchesini evidencia para explicar a tendência hibridadora do humano. Tal dimensão, característica do comportamento de mamíferos nos cuidados parentais, de atenção, zelo e acolhimento aos filhotes, sumariamente forte nas relações mães-filhotes e em suas expectativas, estendidas naquelas sociais, responde à nossa capacidade de transformação em profunda interação com as alteridades humanas e não humanas:

dominadas. As transformações biotecnológicas apontam para uma questionamento de um humanismo antropocêntrico (até mesmo o pós-humanismo heideggeriano, desse ser que é pastor da morada do ser) e merecem uma re-interpretação sobre as relações entre humanidade e animalidade, e as fronteiras entre natureza e cultura. Sua consideração sobre a biotecnologia vai para além de compreendê-la como qualquer coisa contra o humano: expõe que a manipulação genética, sendo uma realidade, mostra que a biotecnologia está conseguindo modificar o substrato do comportamento humano, começando uma nova história. Quanto às teorias do pós-humano, essa é uma realidade que já vem sendo sintetizada em trabalhos bastante conhecidos, como de Donna Haraway, no Manifesto Ciborgue (1985), partindo da problematização do humano baseada principalmente pelas transformações tecnológicas corpóreas e seus sentidos políticos. Desde sua origem, sua efetivação é marcadamente estética, onde inúmeras são as imagens portadoras de referências pós-humanas, problematizadoras do humano - da sua corporalidade e da sua entidade simbólica única e soberana - expressas principalmente pela literatura, nas figuras de Frankenstein, de Mary Shelley (1831), pelo cinema, nos filmes de ficção científica, Blade Runner (Scott, 1982) Robocop (Verhoeven, 1987) e The Terminator (Cameron, 1984), para citar as imagens mais emblemáticas. Também as experiências artísticas e performáticas atravessam e problematizam as fronteiras do corpo no limiar dos vestígios do humano: ora para explicitar o seu estado obsoleto (Stelarc), ora para ampliá-lo e recriá-lo na arte telemática, eletrônica e digital. Para fins de equilibrar a funcionalidade orgânica, a medicina também contribui para a ideia do pós-humano, com a alteração do corpóreo por meio de dispositivos tecnológicos; próteses, marca-passos, implantes, etc. 
O caminho epimelético abre o sistema-homem à hibridação com o não-humano e transforma o mundo em um vasto horizonte de referências.

Numa visão pós-humanística, o saber é um processo de acolhimento das alteridades; é, assim, um ato de hospitalidade que alarga a perspectiva do homem e constrói novos predicados para o ser humano, um evento que igualmente o conjuga ao mundo através de um crédito referencial. A cada passo hibridador, o homem aumenta a sua necessidade de alteridade, não o seu domínio sobre as alteridades: essa consciência poderia ser uma advertência para o homem do século XXI, a fim de evitar perigosas negligências em relação à realidade externa que o levem a pensar-se como uma ilha auto-suficiente. É então indispensável uma nova cultura que olhe a tecno-ciência como um componente central na realização do homem, capaz de ampliar sua perspectiva e de mitigar o antropocentrismo, através da integração do não-humano. (MARCHESINI, 2010, p. 176177)

Marchesini chama esse ato de hibridação de antropo-poiese ${ }^{54}$, a vocação da própria espécie humana à contaminação, ao contato com as alteridades não humanas, não sendo autoexplicável, isto é, não sendo passível de ser compreendido única e exclusivamente pela referência humana. Isso faz do pós-humanismo "um pensamento inclusivo do não humano" (MARCHESINI, 2010, p. 181), que põe em questão a identidade autárquica do homem opositiva aos elementos não humanos. Essa reflexão distancia-se da ideia de pós-humanismo ou de singularidade ${ }^{55}$, associada à superação ou à obsolescência do homem, mesmo que essa seja preconizada por alguns.

A questão fundamental, a nosso ver, encontra-se na proposição exposta por Marchesini da superação do humano enquanto identidade independente, condicionada aos valores antropocêntricos e impermeáveis às transformações tecnológicas hibridizantes:

O pensamento pós-humanístico se opõe, portanto, in primis, à idéia de humanidade como entidade autárquica, capaz de realizar-se de

\footnotetext{
${ }^{54}$ Combinação de antro (homem) e poiese (do grego, "produzir", "criar", "fazer”, "engendrar”).

55 Segundo o sociólogo português Hermínio Martins, um comentário de J. Von Neumann, nos anos de 1950, já apontava que a "singularidade" seria resultado das transformações tecnológicas que ocasionariam mutações extraordinárias rumo a uma singularidade da espécie. Posteriormente, tornar-se-ia uma palavra utilizada nos discursos do movimento dos 'trans-huma-nistas'. Para estes trans-humanistas, haveria "um sucessor legitimo do homo sapiens como sumidade cognitiva, cujo veículo seria um ente pós-biótico, realizado através de uma auto-evolução, por uma série de transformações endossomáticas ou endopsíquica, aproveitando a tecnociência disponível a cada momento" (MARTINS, 2003, p. 53).
} 
modo autopoiético e explicável no seu interior: a crítica não é só em relação à pretensão de considerar o homem como protótipo explicativo do mundo, mas sim de considerar que se possa encontrar uma explicação exaustiva das características humanas fazendo um simples reconhecimento das características da espécie Homo sapiens. O humano não tem mais um perfil pré-definido, quer do reflexo em negativo da carência, quer da plenitude determinística da instrução genética, mas se estrutura em modo declinatório, ou seja, hibridando-se com a alteridade. O humano é, portanto, um limiar de desenvolvimento dada do diálogo com o não-humano, diálogo de que não se pode prescindir caso se deseje entender o caráter mais autêntico da dimensão cultural. (MARCHESINI, 2010, p. 177)

Essa perspectiva aberta pelas ideias pós-humanistas de Marchesini tangencia algumas noções conceituais que nos orientaram no desenvolvimento da pesquisa e configuraram um determinado horizonte epistêmico, desde o que agrega a perspectiva reticular até nossa forma de associar, relacionar, segundo a Teoria AtorRede, o processo de digitalização, por sua combinação com os grupos locais e seus territórios e os processos reticulares e midiáticos digitais.

Finalmente, sua argumentação sobre a dimensão da antropo-poeise, nos é inspiradora para analisarmos a capacidade da cultura de produzir vínculos, espaço de diálogo com as alteridades não humanas:

A cultura é a dimensão da antropo-poiese, é a gramática geradora do diálogo, é espaço virtual sustentado por uma complexa matriz de vínculos e possibilidades intrínsecos, e igualmente por um horizonte de parceiros não-humanos que se prestam ao diálogo. A cultura é, portanto, o fruto de uma conjugação, é uma incorporação da herança sob perspectivas diferentes, oferecidas de uma contrapartida capaz de colocar-se em modo referencial em relação a nós. Na cultura, devemos, por isso, reconhecer um débito referencial contraído com as alteridades não humanas, exatamente como o Si se realiza no encontro com outras pessoas ou uma cultura no encontro com outras culturas.

Essa virtude hidridizante tem um sentido vasto, complexo e polissêmico, o que nos permite repensar a noção de cultura como toda e qualquer produção cultural simbólica dinâmica, relacional, compartilhada, negociada e significada pelo agenciamento e interação com os meios de comunicação e com as alteridades não humanas. 
1.2.2. Mídias digitais

O processo comunicativo existe dado uma materialidade que lhe é intrínseca, ou seja, seus suportes materiais da informação, e que está na origem do termo latino medium, "os media", forma reduzida advinda da expressão mass media ${ }^{56}$. Seu sentido etimológico - meio e ligação, articulação e união - tornou-se a referência sublime das produções comunicativas em massa, principalmente do rádio e da TV, os mass media, impregnando-Ihes de uma razão instrumental para um público indistinto. Seria essa a primeira proposta teórica oriunda dos estudos comunicativos baseada em seus efeitos (LASSWELL, 1948), apontando em direção a uma teoria da cultura de massa e da indústria cultural (ADORNO e HORKHEIMER, 1985). Essas teorias são ineficazes para avaliar as dimensões das mídias digitais no âmbito das culturas locais, pois, nos casos analisados, não são expectadoras passivas dos conteúdos emitidos pelos aparatos das mídias de massa. As culturas locais analisadas são, ao contrário, produtoras de conteúdos das arquiteturas informativas reticulares. Ao mesmo tempo, essas arquiteturas informativas são um dos indicadores do processo de digitalização, formando o conjunto constituinte das relações habitativas entre as culturas envolvidas e seus territórios.

Assim, contudo, é certo que a própria passividade da recepção do conteúdo emitido pelas mídias de massa foi, ao longo das últimas décadas, fortemente criticada por diversos estudiosos.

O filósofo italiano Gianni Vattimo (1989) apontou como uma das consequências da difusão das mídias de massa (jornal, rádio e TV) a tomada da palavra por parte de subculturas historicamente sujeitadas à visão unitária da história por um pensamento ocidental. Esse fator tecnológico e comunicativo possibilitou o surgimento daquilo que viemos chamar de "multiplicação de visões de mundo":

[...] a impossibilidade de pensar a história como um curso unitário, [...] não surge apenas da crise do colonialismo e do imperialismo europeu; é também, e talvez mais, o resultado do aparecimento dos

\footnotetext{
${ }^{56}$ Embora seja correto designar os media (no plural) em português, no Brasil é amplamente difundido o uso do substantivo feminino "as mídias", considerado para alguns autores, a exemplo do Prof. Ciro Marcondes Filho, sua forma no singular, como uma construção linguística espúria, ilegítima e empobrecedora (MARCONDES FILHO, 2009, p. 249).
} 
meios de comunicação de massa. Estes meios - jornais, rádio, televisão, em geral tudo aquilo a que hoje se chama telemática foram determinantes para o processo de dissolução dos pontos de vista centrais, daqueles que o filósofo francês, Jean François Lyotard, denomina as grandes narrativas. [...] O que de fato aconteceu, não obstante todos os esforços dos monopólios e das grandes centrais capitalistas, foi que a rádio, a televisão e os jornais se tornaram elementos de uma explosão e multiplicação generalizada de Weltanschauungen, de visões de mundo. (VATTIMO, 1989, p. 13)

Essa interpretação do papel ativo das mídias na pluralização de visões de mundo nos remete à tese desenvolvida por Jesus Martin-Barbero (2001, p. 26), qual seja, da mídia como elemento da mediação cultural, "parte de um processo comunicativo como contexto no qual os fenômenos midiáticos são vivenciados pelas pessoas e grupos que produzem e re-produzem sentidos". $\mathrm{Na}$ operação de deslocamento "dos meios às mediações", Martin-Barbero (2001, p. 31) destaca o papel ativo dos "receptores" das mensagens no processo comunicativo, desvinculando-os da suposta passividade:

As mensagens veiculadas na mídia se transformam quando os
receptores se apropriam delas. E são diversificados os sentidos que
elas ganham, decorrentes das diferentes mediações com as quais os
receptores vivenciam. E na medida em que elas ganham novos
significados, elas se desdobram em novas práticas, em ações. É
possível desmistificar o poder onipresente da mídia e investir nas
possibilidades de ação dos receptores e na construção de um saber
coletivo.

Nesse sentido, as "mídias" ampliam e realçam novas configurações sociais e culturais, resultando em que cada novo modelo comunicativo tem sua influência no âmbito da cultura, transforma nossas percepções e formas de pensar, bem como propicia novos ambientes socioculturais, alterando a situação social (MEYROWITZ, 1995) e a condição habitativa (DI FELICE, 2009).

Para Marshall McLhuan (1969) são os meios, mais que as mensagens, a configurar, transformar e modificar as ações e as associações humanas:

O "meio é a mensagem", porque é o meio que configura e controla a proporção e a forma das ações e associações humanas. O conteúdo ou usos desses meios são tão diversos quão ineficazes na estruturação da forma das associações humanas. (MCLUHAN, 1969, p. 20-22) 
O meio, ou processo, de nosso tempo - de tecnologia elétrica - está remodelando e reestruturando padrões de interdependência social e todos os aspectos de nossa vida social. Por ele somos forçados a reconsiderar e reavaliar, praticamente, todos os pensamentos, todas as ações e todas as instituições anteriormente aceitos como óbvios. [...] As sociedades sempre foram moldadas, mais pela natureza dos meios que os homens usam para comunicar-se que pelo conteúdo da comunicação. (MCLUHAN, 1969, p. 36)

Por existir um intenso debate exposto pela fratura das posições tecnoutópicas/tecnofóbicas nos estudos comunicativos, nesta tese procuramos ultrapassar as abordagens dualistas e pôr em suspeição os fatores exclusivos de uma determinação tecnológica, os efeitos e as consequências das mídias para as culturas.

Vale ressaltar, novamente, que nosso caminho teórico não parte do entendimento da influência das mídias nas culturas; nosso interesse é perscrutar as especificidades e reciprocidades das interações midiáticas digitais, culturais, no tocante a determinados grupos locais e suas territorialidades. Buscamos, portanto, em nossa análise, cotejar as associações e as influências recíprocas, primando pelo estudo das arquiteturas informativas, suas práticas, suas agencialidades e narrativas (identificações).

As mídias digitais ou produções midiáticas digitais se apresentam como vetores das interações dos grupos que se diferenciam culturalmente e que transformaram radicalmente as experiências sociais nos últimos tempos com a difusão da conexão e do acesso à Internet, oferecendo novos recursos para a construção de Si por sua assunção ordinária e cotidiana. É um fenômeno do qual a recorrência dos processos comunicativos globais, no caso da digitalização e da difusão das redes, em contato com realidades locais, viabiliza a emergência de identidades étnicas nesses espaços comunicativos.

Ao incorporamos as produções midiáticas digitais no escopo de nossa análise, a forma como elas resultam em interações com as culturas locais e suas territorialidades, estamos nos referindo às arquiteturas informativas digitais, aos novos recursos para a produção, a colaboração, o compartilhamento, a difusão e a circulação da informação. Tais produções digitais são consideradas por nós como mídias nativas ${ }^{57}$, segundo a reflexão proposta por Di Felice, na qual o caráter

\footnotetext{
${ }^{57}$ O termo "mídias nativas" foi originalmente proposto por Massimo Di Felice na primeira edição do Seminário "Mídias Nativas", ocorrido em São Paulo, em 2006, e organizado pelo Centro de
} 
"nativo" da mídia, e não somente dos sujeitos, recorre a uma ruptura conceitual em que as interações midiáticas são portadoras de significados para o social e para o âmbito da cultura, capazes de romper com as dualidades centro/periferia; cultura erudita/popular; técnica/humanos, delineadoras de espacialidades conectadas. Isto é, são produções midiáticas de grupos locais - indicadores de uma digitalização não só de suas culturas, mas também de seus territórios - que estão presentes nas redes digitais, nos casos a serem relatados mais adiante, na segunda parte desta tese, que nos oferecem um interesse edificante de reflexão sobre seu caráter ecossistêmico e atópico ${ }^{58}$.

Se estamos lidando com produções midiáticas difundidas e amalgamadas nas arquiteturas informativas digitais, provedoras de intersecções e interações culturais, midiáticas e espaciais, com potencial analítico e empírico, são elas, a partir dessas associações, as difusoras de imagens e produtoras de imaginários. Isso quer dizer que a emergência das redes digitais e suas arquiteturas informativas interativas reticulares produzidas pelas apropriações, interações e produções midiáticas nativas implicam não só a alteração das nossas percepções relacionais, derivada desse alargamento do acesso às tecnologias digitais, mas a elaboração e difusão de imagens e imaginários de mundo. Habitamos não só essas arquiteturas informativas e seus circuitos interativos como também somos habitados pelo seu turbilhão de imagens fomentadas pelas autopercepções, identificações e interações espaciais, tomadas pelo contexto local e global dos fluxos informativos.

Por esses fluxos informativos constituírem-se imagens midiáticas recorremos à leitura do antropólogo Arjun Appadurai (2001) sobre as interações midiáticas formadas por fluxos culturais globais, como mediascape. Essas paisagens midiáticas são ocasionadas pelo cruzamento do global com o local e pelos recursos eletrônicos de produção de imagens que modificam a nossa percepção de mundo. O papel da

Pesquisa ATOPOS, da Escola de Comunicações e Artes da USP, no qual foram apresentadas as produções midiáticas e as narrativas eletrônicas indígenas, com a participação de comunicadores e produtores guarani, terena, potiguara e pesquisadores acadêmicos. Esse termo aberto de mídias nativas surge, portanto, do seminário homônimo, inicialmente proposto para a apresentação dessas produções indígenas e para o debate entre seus produtores, pesquisadores e público presentes. $\mathrm{Na}$ sua segunda edição em 2008, essa noção amplia-se, abrangendo as experiências de jovens de periferia e de outros grupos historicamente marginalizados por parte da produção de conteúdo das mídias de massa.

${ }^{58}$ Conceito associado ao habitar atópico, de Massimo Di Felice, inspirado no conceito do habitar de Heidegger, a quadratura do Ser-aí, do Dasein, que está em cima da terra, debaixo do céu (divino), ao lado das coisas e dos homens. Di Felice reelabora essa condição ontológica relacional do Dasein de Heidegger como modo de estar no mundo em simbiose com as tecnologias de comunicação, associando sujeitos, tecnologias e território. 
mídia (e das interações com os sujeitos enunciadores de identidades étnicas) na construção dessas paisagens midiáticas aponta para a mobilização de repertórios imagéticos e para a importância da imaginação nos processos de construção da localidade e das identidades de grupo em condições diaspóricas (sincréticas e transculturais) ${ }^{59}$ e de afirmação de suas diferenças culturais.

Ponderamos, nessa perspectiva, um entendimento pontual de imagem por compreendermos que o debate em torno dela, recorrente desde as origens da filosofia $^{60}$, atualiza-se, envolvendo em seus meandros as profundas transformações sociais e culturais intensificadas e consubstanciadas pelas tecnologias de informação e comunicação e pelos seus aparatos de virtualização. As imagens provocam e são 'provocadas' pela mesma técnica que as faz existir e reproduzir. São engendradas, assim, questões que as submetem ao seu sentido ontológico e às suas relações com o real e que constituem a nossa experiência contemporânea no mundo e afetam o domínio humano, dispondo as bases da experiência hidridizante e pós-humanista (MARCHESINI, 2010).

Dito isso, as imagens presentes nas arquiteturas informativas e interativas serão relacionadas, nesta tese, menos por seu sentido de 'representações mentais' de um objeto ou de uma experiência real e mais pelas 'tecnoimagens' vinculadoras de um real que efetivam. Essas tecnoimagens, imagens mediatizadas, suas transformações perceptivas vinculadas às formas de existência, mediadoras sociais, são permeadas por uma modalidade peculiar, diferentemente da 'imagem' que nega ou falsifica o real.

Nas palavras do sociólogo português José Luis Garcia (2009, p. 262-263): “A tecnoimagem oferece-nos fragmentos visíveis de realidade acerca das quais não

\footnotetext{
${ }^{59} \mathrm{Na}$ oportunidade da análise dos casos, veremos que essa condição diaspórica ocorre com mais intensidade em culturas sujeitas aos processos de migração, no caso mais evidente, a dos Cabilas, na França. Os processos midiáticos digitais apontam para a perspectiva diaspórica da cultura, em que a mesma é um devir, um contínuo tornar-se (HALL, 2003, p. 44), a qual se constitui por meio da tradução e da mediação cultural realizada por meio das tecnologias digitais.

${ }^{60}$ Os antigos gregos serão os primeiros a tecer a divisão entre imagem e real, calcificada nas origens da metafísica com a separação entre mundo sensível (fenômenos) e mundo das ideias, fundamentada na crítica realizada por Platão às imagens (e ao mito), entendidas por ele como 'falsa', 'incorporal', ou 'não ser'. Para Platão, a imagem seria esse algo enganoso apreendido pelos sentidos, uma imitação dos fenômenos, isto é, apresenta uma segunda degradação quando representada. Essa divisão metafísica expressar-se-ia também em outras dualidades, original/cópia, presença/ausência, etc. Na teologia católica, a divisão enveredou-se entre o visível e o invisível, e nos modernos tais divisões são concebidas na "lógica pura dos possíveis, procurando [os modernos] reger as passagens entre 'real' e 'possível'” (BRAGANÇA DE MIRANDA, 2008, p. 28).
} 
temos uma experiência directa e de fenômenos que de outra forma permaneceriam velados às nossas capacidades visuais".

Simultaneamente, a realidade e a ação são permanentemente afetadas pelos acontecimentos veiculados pelas mídias e que transformam a própria natureza da imagem, independente da sua função de representação:

Importante [...] é salientar que a própria tecnoimagem sobre uma metamorfose ontológica, passando a ser independente da função de representação e a transformar-se em meio de composição do mundo. Com as faculdades do computador e dos meios multimedia, o universo das imagens pode prescindir do real como fonte, as imagens podem ser objeto de composição pelas possibilidades abertas pela informática, podem interferir umas com as outras através de uma programação que implica algo como a autorealização do reino das imagens. (GARCíA, 2009, p. 266)

De acordo com Castells (2003), como mencionado anteriormente, na nossa contemporaneidade é por meio das imagens que temos a experiência com o real, seu aspecto ontológico impele, portanto, sua vinculação necessária, mediadora da nossa relação com a natureza. Portanto, a imagem técnica, embora tenha uma especificidade moderna e pós-moderna, dado o papel das mídias em sua difusão, tem um caráter fundamental na nossa relação com o real. Para pensá-la, o também sociólogo português José Bragança de Miranda retém o sentido dela justamente como forma de operação com o real, que o transmite e o transforma enquanto tal. A imagem é filtro que separa, mas medeia e cumpre seu duplo papel de elo, de unificador e de separador dos humanos da Physis (natureza). Existiriam, portanto, as dependências entre o real e a imagem cuja realização revela a potência dela, "a matéria, o existente, é da ordem da insuficiência, ser insuficiente incumbe à realização da promessa de imagem que contém" (BRAGANÇA DE MIRANDA, 2008, p. 10). Dessa forma, a imagem não é uma categoria menor em relação ao real, ao contrário, a imagem cumpre uma vinculação necessária com o real para que o mesmo possa se 'realizar'.

Essa "realização" se traduz no modo como nossa própria maneira de ser e de pensar é perpassada pela imagem. Isso, nas palavras do sociólogo francês Michel Maffesoli (2001, p. 53), denota essa nova função como "mesocosmo", "meio, vetor, elemento primordial do vínculo social", um meio, um "entre" o "microcosmo" pessoal e o "macrocosmo" coletivo. 
Entretanto, alguns autores atribuem às imagens técnicas, veiculadas pelas mídias, uma função de encobrir o mundo, artificializá-lo, distanciar os humanos do real ou daquilo que é humano e do que pode ser transformado em ação. O filósofo Jean Baudrillard (1991) enfatizou que o excesso de imagens promove o enfraquecimento do real, pois sua massificação destrói a possibilidade de distinção entre o que é ou não real, criando, assim, uma hiper-realidade. Numa lógica iconoclasta, Baudrillard avalia a profusão de imagens contrária àquilo que é domínio do humano. Ao contrário dessa concepção, para Bragança de Miranda (2008) o simulacro ou a imagem jamais é algo sem referente. Concordamos, portanto, com o sociólogo português: não existe uma realidade "dada", a priori, que possa ser "encoberta" ou simulada.

Da mesma forma que as imagens são produzidas pelas mídias digitais em seus diversos formatos (textual, fotográfico, audiovisual) e compartilhadas nas redes digitais, como veremos nas partes II e III desta tese, relacionamos seu conjunto simbólico ao imaginário, mantido pela dinâmica da imaginação. Partindo da imaginação como real, e vice-versa, no sentido de Gilbert Durand (2002), e como força, um catalizador e patrimônio de grupo que dá sentido aos seus membros, assim referido por Michel Maffesoli (1996, p. 261), assentam-se no imaginário, num mundus imaginalis, os comportamentos, os mitos, os rituais, as memórias e as narrativas de cada grupo, mediando seus universos simbólicos e também tecnológicos como formas culturais de habitar o mundo.

Nas palavras de Appadurai, as mídias fornecem recursos para a imaginação de si como projeto social cotidiano, dispondo principalmente para os grupos migrantes novos modos de ação e de vínculos alhures, imprimindo-lhes um sentimento de grupo que começa a imaginar e a sentir coletivamente, nos termos de Benedict Anderson (1996), de uma "comunidade imaginada". 
1.2.3. Metaterritórios e espacialidades comunicativas

Recorremos, nesta tese, finalmente, à noção de metaterritório (DI FELICE; TORRES; YANAZE, 2012) ${ }^{61}$, fundamentada nas relações com as mídias, os fluxos informativos e as culturas, em que comunicabilidade (pôr em comum) e sua materialidade (médium) ressignificam a experiência espacial e lhe dá os instrumentos de apreensão, representação e percepção, também profundamente associados às especificidades históricas e culturais de grupos e sujeitos, ou coletivos, a eles associados.

De fato, além da categoria de tempo, o espaço vem sendo profundamente alterado enquanto experiências (temporais e espaciais) com as redes digitais. Ao longo dos diversos estudos, sejam de geógrafos (SANTOS, 1988) e de outros cientistas sociais (SEGATO, 2005), as diferenças entre espaço e território marcam um campo da assimilação da nossa experiência vivida com a representação das suas acepções.

Para a antropóloga Rita Segato (2005, p. 2), baseando-se no modelo lacaniano de realidade - o real, o imaginário e o simbólico -, o espaço remete ao domínio do real, de um infinito que excede nossas categorias de apreensão, apontando-o por sua simultânea rigidez e elasticidade, de ser "contido e incontido, narrável e não-narrável, comensurável e furtivo". O território ${ }^{62}$, por sua vez, é uma apreensão discursiva do espaço representado e apropriado, "realidade estruturada pelo campo simbólico" (SEGATO, 2005, p. 2). Na esteira da distinção, Segato articula o lugar ao suporte das produções espaciais e territoriais, por onde essas apreensões se concretizam. Todas essas diferenças entre território, espaço e lugar encontram-se em suas efetivações, percepções e concepções orientadas por um sentido de Nós/Eles, uma diferenciação identitária:

\footnotetext{
${ }^{61}$ Incorporamos a categoria de metaterritório, desenvolvida por Di Felice, Torres e Yanaze (2012, p. 2009) enquanto "ecossistema informativo, um continum entre homem, tecnologia e ambiente cujo dinamismo relacional entre esses elementos constitui o próprio habitar, a forma de ser em situação, em constante transformação", para repensá-la dada as especificidades das culturas locais. No conjunto da obra dos autores, "território", "espaço" e "ambiente" são tomados por sinônimos. Buscamos especificar seus sentidos por meio do texto de Rita Segato para melhor caracterizar o local digital, eixo teórico desta tese.

${ }^{62} \mathrm{O}$ território é também referência da base geográfica (terra, fauna, flora, minérios, ar e mar, etc.) do Estado pelo qual exerce sua soberania.
} 
Esse conjunto de características faz com que aquilo que denominamos território constitua-se em significante de identidade (pessoal ou coletiva), instrumento nos processos ativos de identificação, e representação da identidade [...] O território é o cenário do reconhecimento; as paisagens (geográficas e humanas) que o formam são os emblemas em que nos reconhecemos e cobramos realidade e materialidade ante nossos próprios olhos e os olhos dos outros. (SEGATO, 2005, p. 3)

Segato (2005, p. 19) propõe um modelo de análise baseado no caráter histórico e político da noção de territorialidade acionada pela comunalidade ${ }^{63}$ dos sujeitos, pelos seus atos de fala, instaurada por um sentido móvel do espaço, porque o território é um atributo espacial de uma determinada população, formado por paisagens topográficas, ambientais, designativas de emblemas reconhecíveis, vetores de uma realidade e materialidade reconhecíveis e compartilhadas.

Extraímos desse modelo uma noção de territorialidade associada a uma comunicabilidade materializadora de espacialidades compartilhadas por meio do realce e da seleção de índices de pertencimento, de memórias, das quais, porém, em nosso entendimento, são intrínsecos os meios (mídias) pelos quais são erigidas essas linguagens e interações comunicativas, também criadoras de metaterritorialidades (DI FELICE; TORRES e YANAZE, 2012).

Esse é um argumento que nos aproxima da noção de espaço acústico de McLuhan, apreensão de diferentes e simultâneas percepções do espaço, prática dialógica de sentidos, enquanto ambiente pervasivo sensorial (MACHADO, 2011). Os algoritmos fundamentais dessa concepção ambiental de espaço na era elétrica são: invisibilidade, envolvimento, simultaneidade e interação. É esse estímulo sensorial advindo dos meios de comunicação pelos seus processos e modos de interação, seus efeitos em termos de percepção, suas ressonâncias e reverberações, conversores de informação para a consciência (no sentido neurológico e coevolutivo) e para a identidade, um sensus communis, que fomentou a concepção de aldeia global, uma percepção ecológica ambiental projetada pelos meios promotores de uma consciência e mente planetária.

Esse é um entendimento englobante e perceptivo da noção de espaço construído pelos meios de comunicação. Ao lado das formas comunicativas do habitar, Di Felice (2009) nos leva a entrever o espaço para além daquele da

${ }^{63}$ Comunalidade tem origem na palavra francesa communalité e refere-se a uma forma social, uma dimensão da cidadania advinda da relação com os outros. 
interlocução humana (linguagem) da sua limitação geográfica e dos seus repertórios emblemáticos. A digitalização parece, dessa forma, atuar numa outra ordem de territorialização do espaço: perceptiva sensorialmente emulada pelas novas linguagens midiáticas, audiovisuais, hipertextuais, conectivas. Hibridação informativa do espaço geográfico, uma metaterritorialidade, um ecossistema informativo apreensível pela conexão interativa da informação com o território.

Próxima a essa direção, Lucrecia Ferrara (2008), primando pela análise da unidade comunicação/espaço/cultura, agrega os novos sentidos de espacialidades caracterizados por diversos processos interativos. Para Ferrara, o espaço é um fenômeno "entre" a comunicação e a cultura, formado por três elementos essenciais: primeiro sua característica construtiva, sua construtibilidade ${ }^{64}$, as interações de base comunicativa e as dimensões culturais que impregnam aquela comunicação (interação, transmissão e vínculo). Ela propõe, assim, o estudo do modo como o espaço se transforma em espacialidade ao surgir como categoria epistemológica para a análise da comunicação "que vai da relação à vinculação ou da mensagem de um conteúdo para a transmissão de uma atmosfera ambiental de constante interatividade" (FERRARA, 2008, p. 13).

Nessa percepção ambiental da comunicação, segundo Ferrara, a interação, a transmissão e o vínculo derivam das mídias, em conformidade com aquilo que Muniz Sodré (2008) chama de biosmidiático, a midiatização como um novo bios (nova forma de existência humana na pólis) acrescentada às três formas formuladas por Aristóteles na sua Ética a Nicômaco, vida contemplativa, vida política, vida prazerosa. A quarta esfera existencial seria a da midiatização - uma ordem de mediações socialmente realizadas, um tipo de interação - tecnomediações caracterizadas por uma espécie de prótese tecnológica e mercadológica da realidade sensível, denominada médium, fluxo comunicacional acoplado a um suporte técnico (SODRÉ, 2008, p. 22).

Contudo, o biosmidiático, essa nova forma de vida, de bios, âmbito no qual se desenrola a vida, na acepção dada por Sodré, é, de certa forma, entorpecido por uma ideologia obscurantista ${ }^{65}$ que impede um olhar laico sobre as circunstâncias e

\footnotetext{
${ }^{64}$ Representação e apresentação do espaço "enquanto elemento que intervém na materialização da cultura e no modo pelo qual ela se comunica na história" (FERRARA, 2008, p. 9).

${ }^{65}$ Nas palavras de Sodré (2008, p. 28): "Por mais despolitizado que pretenda parecer, o biosmidiático implica de fato uma reconfiguração do mundo pela ideologia norte-americana (portanto, uma espécie de narrativa política), caucionada pelo fascínio da tecnologia e do mercado. Nele, estão
} 
os significados de experiências tecnossociais. É certo que as tecnologias comunicativas digitais não são neutras e fomentam diversas formas de poder ou relações de poder, no sentido foucaultiano, mas estas não se resumem e se limitam à resignada teoria do imperialismo.

Retomando a ideia de espacialização, esta qualifica seu sentido midiático de fluxo informativo (diferente da ideia de espaço de fluxos ${ }^{66}$, elaborada por Manuel Castells), reposiciona a própria localidade, pelo qual por meio do digital, assume um devir em contextos não somente locais como também globais.

Dessa forma, a expressão "local digital das culturas", proposta nesta tese, inspirada na obra O local da cultura, do crítico cultural indo-britânico Homi Bhabha $(2003)^{67}$, procura reinterpretar essa condição informativa glocal das culturas locais. Concedendo ao local da cultura uma leitura teórica como entre-lugar, um contexto intersticial formado por campos de perfomatização identitários, deslizantes, marginais e estranhos, oriundos das relações tecno-informativas e dos processos interculturais.

Uma forma de "fazer espaços", recriações de "localidades que se prestam a um habitar" (HEIDEGGER, 2003, p. 15), num continum de lugares, corpos, identificações, percepções, fazendo desse local digitalizado um forma de presença nas espacialidades e nos fluxos globais. Do ponto de vista teórico-espacial e lógicosituacional do filósofo alemão Peter Sloterdijk (2009, p. 23) ${ }^{68}$, a vida "produz sempre

presentes as marcas essenciais de uma "universalidade" americana. Se o Império Romano dominou o mundo pela espada e pelos ritos, o Império Americano controla pelo capital e pela agenda midiática do democratismo comercial (informação, difusionismo cultural, entretenimento)".

${ }^{66} \mathrm{O}$ espaço de fluxos, concebido por Manuel Castells, é o novo suporte de práticas sociais, marcado pela esterilidade do lugar, porque não conta com seus referentes localizados e históricos. $O$ sociólogo espanhol caracteriza esse espaço de fluxos, pelas novas formas e processos espaciais globais, como formado por três camadas: a primeira pelo seu suporte material, circuitos de impulsos eletrônicos, práticas simultâneas, formas de poder; a segunda, formada por seus nós (centros de importantes funções estratégicas) e centros de comunicação que redefinem as cidades globais. Determinados lugares possuem um perfil que se conecta diretamente com seus semelhantes e com os constituintes da rede; a terceira e última camada do espaço de fluxos é aquela que organiza espacialmente as elites gerenciais dominantes, seus lugares, seus símbolos, constituídos por uma exclusividade não local, mas regida por conceitos e materiais cada vez mais globais, cosmopolitas e Vips (CASTELLS, 2001a, p. 403-455). Castells identifica na arquitetura pós-moderna, "ahistórica", a manifestação do espaço de fluxos, cujo abandono da experiência local, situada, histórica e cultural se calcifica nessa (pós) arquitetura e design que não diz nada disso, declarando, na mistura de suas formas, o fim de todos os significados.

${ }^{67}$ Publicação original: BHABHA, Homi. The location of culture. Routledge-London: New York, 1994. Bhabha (2003) focaliza sua crítica cultural na relação colonizador/colonizado, partindo do desconstrutivismo do sujeito colonial, formado neste entre-lugar híbrido e polifônico das narrativas coloniais.

${ }^{68} \mathrm{Na}$ triologia Sphären (Esferas), Peter Sloterdijk lança sua obra monumental, Sphären I - Blasen (Esferas I - Burbujas, 1998), Sphären II - Globen (Esferas II - Globos, 1999), Sphären III - 
o espaço no que é e que é nela", articulada em situações, conglomerados, cenários simultâneos, imbricados uns aos outros, perfazendo modos de estar juntos e comunicar-se. Para o filósofo alemão, espaço da vida e espaço vivido formaliza cognitivamente experiências e compreensões epistemológicas da vida, emanando da metáfora da "espuma" - a conexão comunicativa e cotidiana das inúmeras mônadas, desenvolvida no tomo III da sua obra Esferas (2009) - a sobrecarga crítica a qualquer simplificação ontológica, metafísica e holística.

Consideramos, então, o local digital, uma noção central para pensarmos, uma forma de "fazer espaço" no digital, tessitura de espacialidades comunicantes no habitar, no entre-lugar digital como fronteira em que os grupos e seus interlocutores estão presentes por meio dessas produções digitais construídas pelos mesmos, articulando novas estratégias de diferenciação, subjetivação e signos de identificações, partindo de suas produções e interações midiáticas nativas articuladas em redes sociais digitais.

Tal inserção transitiva do local digital nos remete diretamente ao rizoma e à ideia de desterritorialização e reterritorialização de Gilles Deleuze e Félix Guattari (1995). Inspirado pela imagem botânica, o rizoma, haste radiciforme subterrânea ou aérea, a-centrada, traduz a multiplicidade, a heterogeneidade, os movimentos, as conexões e os devires contemporâneos, expondo suas características intermediárias, "entre", no "meio", uma aliança entre as coisas. Formado por linhas multidimensionais, o rizoma, seus bulbos e tubérculos, contrasta com a forma "árvore", conhecimento arborescente, e com as raízes (continuidade de um eixotronco ramificado dicotomicamente a partir dele) e as radículas (sistema fasciculado e pivotante próximo à condição das multiplicidades, mas simulacro das mesmas).

$O$ crescimento das " $n$ " dimensões de uma multiplicidade configura 0 agenciamento e a transformação da natureza dessa mesma multiplicidade. As conexões e os movimentos das linhas de fuga do rizoma delineiam os próprios movimentos de desterritorialização (deslocações) e processos de reterritorialização (efetivações), ambos relativos, presos entre si e em perpétua ramificação e transformação.

Schäume (Esferas III - Espumas, 2004). Até o momento essas obras não foram publicadas no Brasil, nem em versão portuguesa. Tivemos acesso à versão espanhola, publicada pela editora Siruela (Madrid), em 2009. Ambos os volumes e capítulos podem ser lidos separadamente. Sloterdijk tece sua análise 'esferontológica' espacial da coexistência sobre os fundamentos das suas relações uterinas, bipolares e pluripolares, inspirada principalmente nas obras de G. Simmel, G. Tarde e B. Grunberger. 
Nesse sentido, os termos desterritorialização e reterritorialização nos servem para redimensionar um movimento, um acontecimento, dando à nossa tríade simbiôntica e ao nosso metaterritório a dinamicidade da digitalização incorporada em um movimento de ampliação do sentido de espaço, constituição de espacialidade comunicante, desprovido da antinomia do virtual versus real (LÉVY, 1996) e (CASTELLS, 2003).

Tal recorrente contraposição entre virtual/real remonta à tradição do pensamento ocidental, à antiguidade clássica grega, desde Platão com a separação filosófica do mundo "das idéias" e "do sensível". Como já se sabe, a partir desta a emergência dos binários - corpo/mente, alma/matéria e real/irreal - se perpetuou na tradição do pensamento filosófico ocidental.

Ao contrário da originária separação platônica do mundo, Lévy (1996, p. 12) buscou distinguir, na noção de potência e ato de Aristóteles, o virtual de atualização, aplicando a noção de virtual apresentada pelos filósofos G. Deleuze e M. Serres como "um processo de transformação de um modo de ser num outro". A partir desses filósofos, Lévy reinterpreta a virtualização proporcionada pelas novas tecnologias, pelo ciberespaço, como um movimento de devir outro e como uma heterogênese do humano.

Nesse sentido, para Lévy, a virtualização articula as noções de "realidade", "possibilidade", "atualidade" e "virtualidade". Ou seja, o virtual não se contrapõe ao real. $O$ virtual existe e seu modo fecundo e poderoso põe em jogo processos de criação, "perfura poços de sentidos sob a presença física imediata" (LÉVY, 1996, p. 12). Há, assim, a complementação entre real e virtual numa espécie de jogo de espelhos em que ambos são coisas distintas: o virtual se configura como efetivação do real enquanto potência e como um dos principais vetores da criação da realidade.

Para Castells (2003, p. 395), a cultura da virtualidade real, gerada pelo sistema de comunicação digital, faz com que a própria realidade (ou seja, a experiência simbólica/material das pessoas) seja inteiramente captada, "totalmente imersa em uma composição de imagens virtuais [...], no qual as aparências não apenas se encontram na tela comunicadora da experiência, mas se transforma na experiência".

Dito tudo isso, a tríade simbiôntica que confere as características dessa segunda configuração nos emite sinais para uma disposição enunciadora daquilo que nos conduziu para uma interpretação e interação com as arquiteturas 
informativas digitais da Rede Povos da Floresta e do Portal Kabyle.com. Cada uma delas pertence a singulares formas de espacialidades comunicativas, pelas quais se fundem a determinados emblemas identitários e perfazem novas experiências e narrativas de suas culturas.

Finalmente, (con)figuramos nessa incursão teórica os pressupostos aos quais recorremos para matizar a experiência da digitalização de grupos locais - reflexão elaborada concomitantemente às interações com as arquiteturas informativas digitais dos grupos selecionados. Resta-nos, no capítulo seguinte, enunciar os modos pelos quais fizemos do método o caminho da experimentação durante o próprio processo de investigação. 


\title{
PERCURSO INVESTIGATIVO: NOS CIRCUITOS IMERSIVOS, DIALÓGICOS E ATÓPICOS DAS/NAS REDES DIGITAIS
}

\author{
O método não pode ser separado do seu objeto. \\ Werner Heisenberg (apud Morin, 2001, p. 05) \\ Hoje a nossa necessidade histórica é de \\ encontrar um método que revele e não esconda \\ as ligações, as articulações, as solidariedades, \\ as implicações, as conexões, as \\ interdependências, as complexidades.
}

Edgar. Morin (2001, p. 11)

Se as perguntas sobre a caracterização do processo de digitalização de algumas experiências midiáticas de grupos e culturas locais foram o mote da pesquisa que constitui esta tese, faço deste capítulo um espaço para a apresentação e a reflexão dos procedimentos adotados. Um caminho de experimentação no qual o modo de pesquisar em/nas redes deu-se durante o próprio processo de investigação, modulado pelo problema de pesquisa em torno da tríade simbiôntica, da interdependência e da combinação dos elementos culturais, midiáticos e territoriais.

Aliás, estudar fenômenos em rede proporciona ao pesquisador um campo fecundo de possibilidades investigativas, ao mesmo tempo em que impõe desafios. Em decorrência desses fatores, nos últimos anos o Centro de Pesquisa ATOPOS (ECA/USP), do qual faço parte, vem realizando um intenso debate sobre como pesquisar redes digitais a partir de uma perspectiva reticular ${ }^{69}$, em que há a incidência da rede na produção do próprio conhecimento. A investigação de redes digitais para a sustentabilidade, realizada pelos pesquisadores Julliana C. Torres e Leandro K. H. Yanaze, coordenada pelo Prof. Di Felice, publicada em 2012 sob título Redes Digitais e Sustentabilidade, primou por referenciar o debate em torno do

\footnotetext{
${ }^{69}$ Tal perspectiva foi apresentada no primeiro capítulo desta tese.
} 
significado epistêmico das redes, de um modelo de comunicação reticular e interativo, partindo das perspectivas possíveis de pesquisa em contextos reticulares: frontal (pesquisar "a" rede), imersiva (pesquisar "na" rede), dialógica (pesquisar redes interativas, atópica (pesquisar ecossistemas reticulares).

A primeira, a perspectiva frontal é aquela em que a rede é externa ao pesquisador, que estuda sua "estrutura" por um viés instrumental de "coletar dados" e de construir "amostras" para a confirmação de suas prerrogativas teóricas (indutivismo). Há ainda uma nítida percepção de separação entre emissor e receptor das informações presentes nas arquiteturas digitais. São pesquisas com abordagens "estruturalistas", inspiradas na tradição sociológica da Análise de Redes Sociais (SCOTT, 2000; WELLMAN, 2004; etc.), ao lado daquelas voltadas para a pesquisa de mercado e estudo do perfil de consumidores com o uso de 'ferramentas' digitais (DI FELICE; TORRES; YANAZES, 2012). Contudo, tal perspectiva nega a própria dinâmica da rede, anulando-a, pelo olhar externo e frontal estabelecido:

\begin{abstract}
Os limites das abordagens estruturalistas e da análise sociológica das redes em geral estão no fato de que elas se recusam a colocar em discussão os pressupostos conceituais que orientam suas observações e se negam a reconhecer as redes como o advento de uma nova arquitetura do social e da condição habitativa - e, para entendê-las, necessitamos de novos conceitos e de novas linguagens. (DI FELICE, TORRES, YANAZES, 2012)
\end{abstract}

Ao contrário da frontal, a perspectiva imersiva pressupõe a entrega do pesquisador à rede, por onde ele imerge, se conecta, interage, observa "nos" fluxos informativos das suas arquiteturas. Tanto os objetos da pesquisa são e estão nas redes quanto os meios e os métodos de pesquisa. Muito daquilo que vem sendo debatido como etnografia digital (HINE, 2000; AMARAL, 2010), netnografia (KOZINETS, 2010) e antropologia do ciberespaço (RIFIOTIS, 2010) ou ciberantropologia (HARAWAY, 1991) é identificado por Di Felice, Torres e Yanaze (2012) como referentes dessa perspectiva. Estudaremos, mais adiante, essas abordagens, por meio dos trabalhos de Adriana Amaral, que sintetiza os meandros do uso da etnografia em estudos de comunidades virtuais, entre outros.

A terceira perspectiva, a dialógica, a interdependência entre pesquisador e arquiteturas informativas, acontece não só nas redes sociais digitais e em suas 
sociabilidades, mas envolve a interatividade e sua ocorrência na transformação da própria percepção dos participantes envolvidos:

\begin{abstract}
Correspondem a esta abordagem uma concepção dos contextos reticulares como uma perspectiva particular de interação dinâmica e de interatividade que conduz não somente à alteração dos contextos informativos, mas também dos membros que compõem tais contextos: "a interatividade não é somente uma comodidade técnicofuncional; ela implica fisicamente, psicologicamente e sensivelmente o espectador em uma prática de transformação" (Plaza, 2001). Abrese aqui a possibilidade de pensar as relações reticulares num ponto de vista que supera a concepção de fluxo informativo para assumir as formas de uma saída do nível de equilíbrio e de um processo heteronômico. (DI FELICE, TORRES, YANAZES, 2012)
\end{abstract}

Os estudos acolhedores desta perspectiva analisam as transformações da digitalização de culturas locais relacionadas aos seus imaginários, cotidianos e estilos de vida, enquanto processos transorgânicos e sociotécnicos (DI FELICE, TORRES, YANAZES, 2012).

Finalmente, a quarta e última, a perspectiva atópica, que abrange, em sua concepção epistêmica e metodológica, a própria rede como resultado das interações entre coletivos (humanos e não humanos), informações e espacialidades. Tanto os sujeitos interagentes, as arquiteturas informativas e seus ambientes envolvem um plano simbiótico habitativo, cuja delimitação é impossível. Nas palavras dos autores, a rede assume uma condição epistêmica ampla e alusiva da complexidade:

É fundamental ressaltar que a rede manifesta-se como o resultado de um conjunto de interações entre sujeitos (humanos e nãohumanos), técnicas de informação e espacialidades, cuja forma não é nem previsível nem definitiva. Tal condição a descreve não como um "objeto" de estudo, mas como uma específica condição habitativa de interação entre entidades (humanas e não-humanas, técnicas e territoriais) que passam a construir suas especificidades temporárias a partir de suas distintas interferências. O não-objeto "redes de redes" apresenta-se, portanto, como um ecossistema interativo, um infinito conjunto de fluxos interdependentes e não delimitáveis (salvo arbitrariamente), que, enquanto ecossistema, revela-se, ao mesmo tempo, como uma condição habitativa interativa particular e como um conjunto de dinamismos que convidam à contínua saída do próprio ponto de equilíbrio - algo próximo a uma meta-arquitetura interativa, nem interna nem externa, uma pós-geografia que ultrapassa a alteração da dimensão subjetiva para incluir a transformação da territorialidade e da condição habitativa inteira. (DI FELICE, TORRES, YANAZE, 2012, p. 180) 
Cabe ao pesquisador que confronta e adota tal perspectiva conectar-se, abrirse às interações das experiências cognitivas dos ecossistemas reticulares, complexos e não delimitáveis:

O pesquisador que opta por esta abordagem não somente elege relatar também a própria interferência no interior do conjunto das arquiteturas vivas reticulares que o hospedam e o compõem ao mesmo tempo, mas pensa e descreve o inteiro processo através de um dinamismo ecossistêmico que conecta e reúne tecnologias, indivíduos e territórios numa condição habitativa relacional (M. Heidegger), aberta e dinâmica. Um primeiro passo poderia se referir às inteligências territoriais como a expressão de tipos de dinamismos reticulares (coletivos, tecnologia e territórios) que se articulam criando ecossistemas e uma específica condição habitativa, cuja narração constituirá o particular desafio interpretativo e linguístico do pesquisador mais que participante: conectado e hóspede. Como já explicitamente colocado, a questão da ausência de limites e de confins objetivos num continuum de redes de redes, coloca a necessidade da superação da dicotomia entre on-line e off-line baseada na evidência de que a cultura reticular é hoje uma realidade que está também além das redes digitais sociotécnicas, manifestando-se, entre outras coisas, como uma epistemologia emergente. Por isso, o principal mérito dessa afirmação é aquele de querer estudar, ao mesmo tempo, o in e o off-line, uma vez que os ecossistemas não parecem separáveis. (DI FELICE, TORRES, YANAZE, 2012, p. 182-183)

Ao tratar de processos de digitalização dos grupos étnicos, das culturas e de seus territórios, numa perspectiva habitativa, reticular, situada, parcial, e que comunga com os pressupostos atópicos anteriores, não procurei eleger ou seguir uma dessas abordagens a priori. Realizei aquilo que Tommaso Venturini chamou de "promiscuidade metodológica", dantes citada. No decorrer da pesquisa fui experimentando métodos e técnicas que fossem legítimos e coerentes com a problemática e com o objetivo principal desta tese: identificar e analisar os significados da digitalização na tríade, na relação dos grupos étnicos com suas culturas e seus territórios, partindo das suas experiências reticulares digitais.

Considerando esse contexto digital um campo fecundo de possibilidades investigativas, fui impelida ao movimento e à transitividade das interações que criei nos circuitos imersivos e dialógicos ${ }^{70}$. Construindo um campo de análise permeado

\footnotetext{
70 Baseando-se no "sistema circuital" de Gregory Bateson, a também pesquisadora e colega do Centro de Pesquisa ATOPOS (ECA/USP) Mariana Marchesi referiu-se à noção de circuito como a inserção do observador nos sistemas interagentes e sua conexão e trajetória formadora de uma paisagem móvel da pesquisa. Dessa forma, ela propôs, em sua investigação sobre a capoeira nas
} 
pelas conexões e deslocamentos, o percurso investigativo tornou-se um incessante movimento de criação de relações com as interfaces, as linguagens midiáticas, seus atores-redes $^{71}$, suas conexões e narrativas. Fui afetada pelas espacialidades comunicativas e delas fiz novas paisagens reinscritas pelo discorrer.

Portanto, realizei uma pesquisa experimental qualitativa imersiva, dialógica e atópica (DI FELICE, TORRES, YANAZE, 2012), de cunho teórico ${ }^{72}$ e empírico, acerca dos significados da digitalização das culturas locais por meio da imersão nas práticas midiáticas digitais desenvolvidas por duas experiências distintas: a Rede Povos da Floresta e o Portal Kabyle.com.

A eleição de cada uma dessas experiências ocorreu no trânsito da pesquisa e deu-se pela sua significação fenomenológica e hermenêutica que me permitiu, a partir da interação com suas arquiteturas informativas digitais, a descrição e a interpretação do processo de digitalização vivenciado por esses coletivos (no sentido de Latour). Como mencionado anteriormente, não considero a distinção dos momentos online e offline, por isso, além de observadas a relação dos grupos e sujeitos com essas arquiteturas informativas digitais, analisei as práticas,

redes digitais, a "substituição da terminologia "objeto" de pesquisa por "circuito" de pesquisa, considerando: 1. a concepção de sistema circuital, de Gregory Bateson, como um sistema interagente do qual o observador também é parte integrante; 2 . os significados tecnológicos implicados na palavra circuito, associada com frequência não só à eletricidade (circuitos elétricos, curto-circuito, circuitos eletrônicos), mas também à infraestrutura técnica digital (circuitos eletrônicos de base binária, chips, placas e microprocessadores); 3 . a possibilidade de entendimento da palavra circuito também como "caminho", "percurso"' (MARCHESI, 2012, p. 72). Tomando por base essa reflexão, refiro-me aos circuitos imersivos e dialógicos, não ao objeto da pesquisa, mas ao campo de análise de minhas conexões, interações e deslocamentos nas arquiteturas informativas, condutoras dos fluxos informativos, os quais formam conjuntamente uma paisagem ubíqua e deslocativa da pesquisa.

${ }^{71}$ Como mecionamos na introdução desta tese, a noção "ator-rede" refere-se àquela elaborada por Bruno Latour (2004), no qual é tudo aquilo e aquele que age na rede, sendo humano ou não humano. Tal ação não é isolada e não pode ser determinada por suas causas e/ou efeitos. Considero o "ator-rede" também associado às suas relações reticulares informativas, tecnológicas, socioculturais e históricas. Ao longo da tese utilizo o termo "tecno-ator" como sinônimo de "atorrede"

${ }^{72}$ Realizei, obviamente, uma ampla pesquisa bibliográfica apresentada no mapa teórico-metodológico da tese. Durante a análise dos casos selecionados, debrucei-me numa literatura mais específica para a explanação histórica das culturas relacionadas. Foram lidas teses, dissertações, artigos e livros tratando de assuntos correlatos. Parte dessas publicações foi localizada nos banco de dados das bibliotecas da Universidade de São Paulo, Universidade de Brasília, Universidade Paris Sorbonne (Prédio Central) e Universidade de Comunicação e Língua - IULM - de Milão. Foram analisados também artigos das principais revistas brasileiras de comunicação, disponíveis online, além de ter sido de suma importância os encontros com colegas e amigos do Centro de Pesquisa ATOPOS (ECA/USP), nos quais tive a oportunidade de debater o projeto de pesquisa em dois momentos: agosto de 2011 e dezembro de 2012, nos Seminários de Pesquisa do ATOPOS. Nada mais correto mencionar a existência da real inteligência coletiva e conectiva proporcionada pelas redes sociais digitais. 
agenciamentos e relações entre os humanos e não humanos, bem como suas narrativas e performances identitárias.

Finalmente, foram realizados encontros e entrevistas com os seus atoresredes dentro e fora das redes digitais, no intuito de, por meio de um diálogo intersubjetivo, registrar também a percepção e a interpretação destes sobre essas experiências, para, enfim, versar sobre a tradução dos significados desse local digital das culturas.

\subsection{IMERSÕES E CONEXÕES NAS ARQUITETURAS INFORMATIVAS DIGITAIS}

As Ciências da Informação vêm fomentando, nos últimos anos, estudos e análises teórico-empíricas sobre a arquitetura da informação - a organização e o gerenciamento da informação em um site ou plataforma informativa, fundamentada no design e nas interfaces, na disposição da informação e em sua usabilidade para seus usuários/navegadores. Nesse âmbito, a Arquitetura da Informação (com as iniciais em maiúsculas) tornou-se um conjunto de procedimentos de conduta para a construção de ambientes informativos capaz de viabilizar o intercâmbio entre os usuários da informação baseando-se na organização, navegação, nomeação, sistema de busca, pesquisa, projeção e mapeamento (ROSENFELD e MORVILLE, 2006). Estima-se a importância da criação de conteúdos voltados para contextos específicos e a relevância da interação nos espaços informacionais digitais (LIMAMARQUES e MACEDO, 2006, p. 247), procurando, assim, aplicar os princípios de desenhos interativos centrados no usuário para o desenvolvimento de processos, definindo parâmetros de usabilidade e adequação em seu contexto-alvo (OLIVEIRA; AQUINO, 2012, p. 132).

No entanto, estando na posição de pesquisadora-navegadoraexperimentadora, a estratégia inicial foi de literalmente "lançar-me" nos fluxos informativos das arquiteturas digitais de cada experiência selecionada, interagindo com as interfaces, as imagens e com o conjunto híbrido dessas espacialidades, tentando, assim, "capturar" menos a funcionalidade da informação disposta e mais os sentidos dessas produções midiáticas indicativas de um processo de digitalização que esses sujeitos e grupos vivenciam. 
Durante esse percurso imersivo de interação, construí rotas interativas de navegação, assim referidas por Lucia Santaella (2004, p. 34), posto que meus sentidos foram envolvidos pela minha incursão hipertextual, imagética, inorgânica e orgânica, dado que a própria "navegação interativa entre nós e nexos pelos roteiros alineares do ciberespaço envolve transformações sensórias, perceptivas e cognitivas que trazem consequências também para a formação de um novo tipo de sensibilidade corporal, física e mental". Não só interagi com o ambiente informacional de signos híbridos - misturado pelas formas-imagens, vídeos, sons, textos - como dialoguei com os tecno-atores dessas experiências, convertendo-o simultaneamente em meio (médium) errante de pesquisar, uma espacialidade comunicante do encontro intersubjetivo entre mim e essas alteridades nas redes.

Elegi, então, para essa imersão, três casos distintos, que evocam especificidades sui generis desse 'local digital das culturas' emergente dos fluxos informativos globais e glocais. São eles o caso da Rede Povos da Floresta (RPF), particularmente a experiência dos Ashaninka e povos tradicionais ${ }^{73} \mathrm{com}^{2}$ Associação Apiwtxa dos Ashaninka do Rio Amônia e o Centro Yorenka Âtame, participantes da RPF; o portal Kabyle.com, da Associação Internacional Kabyle (França).

Observando cada tipo de arquitetura informativa dessas experiências, pude compor um circuito imersivo, formado por sites, blogs, perfis no Facebook e vídeos no Youtube, de acordo com as linguagens midiáticas dispostas (textuais e audiovisuais) e seus níveis de interatividade (de ação, agenciamento, cooperação, sinergia, simbiose e influência mútua entre mim e seus dispositivos digitais). Dessa interatividade entre os coletivos - pessoas e inorgânicos, hardware e software formou-se uma composição transorgânica para a fruição dialógica que aconteceu e realizou-se pela multidimensionalidade de práticas e de ambiências comunicativas.

A pesquisa que subsidia esta tese investigou essa potencialidade das redes digitais pela qual tanto os grupos interagentes desses ambientes informativos, quanto eu, pesquisadora, não emitem somente mensagens, mas, por meio dos

73 Compreendemos aqui povos tradicionais enquanto grupos culturalmente diferenciados que possuem formas próprias de organização. No Brasil, esses grupos se referem principalmente às comunidades quilombolas, indígenas e ribeirinhas, entre outras. Em Decreto n. 6.040/2007, que institui a Politica Nacional de Desenvolvimento Sustentável dos Povos e Comunidades Tradicionais, - Governo Federal passa a reconhecer as especificidades desses grupos, definindo-os pelos seus aspectos culturais e territoriais de reprodução de suas tradições (BRASIL, Governo Federal, Decreto n. 6040/2007). 
hardwares, construímos trajetos conectivos, manipulamos programas (softwares) e promovemos diálogos maquínicos e intersubjetivos. Isso de acordo com um "campo de possibilidades" existentes entre os membros operantes da comunicação e suas interfaces, dado o próprio estatuto da navegação, assim mencionado por Santaella (2004, p. 163):

\begin{abstract}
o emissor não emite mais mensagens, mas constrói um sistema com rotas de navegação e conexões. A mensagem passa a ser um programa interativo que se define pela maneira como é consultado, de modo que a mensagem se modifica na medida em que atende às solicitações daquele que manipula o programa. Essas manipulações se processam por meio de uma tela interativa ou interface que é lugar e meio para o diálogo. Por intermédio de instrumentos materiais (tela, mouse, teclado) e imateriais (linguagem de comando), o receptor torna-se em usuário e organiza sua navegação como quiser em um campo de possibilidades cujas proporções são suficientemente grandes para dar a impressão de infinitude.
\end{abstract}

No caso da Rede Povos da Floresta (RPF), localizada no período da pesquisa preliminar, imergi no site de 2009 a $2011^{74}$, acompanhando suas atualizações. Estas, organizadas pelas linguagens midiáticas textuais, imagéticas e uma galeria de fotos e de vídeos, me permitiram reconstruir a trajetória do projeto da Rede, da sua articulação ao seu desenvolvimento.

Com interatividade reduzida entre o usuário/navegador e a arquitetura informativa do site da RPF, dado o conteúdo ter sido apresentado sem outros recursos interativos e colaborativos mínimos (como espaço para comentários, etc.), fui impelida a investigar o rastro da RPF em outros ambientes informativos digitais. Dessa maneira, cheguei ao perfil no Facebook ${ }^{75}$ do seu coordenador, Ailton Krenak, e de Benki Pianko, membro da RPF e coordenador do Centro Yorenka Ãtame ${ }^{76}$.

Nesses últimos anos, no Brasil e no mundo, o Facebook vem se tornando uma rede social bastante popular, incorporada em nossa vida informativa cotidiana, com funcionalidades altamente interativas viabilizadoras de uma comunicação

\footnotetext{
${ }_{75}^{74}$ A data da última atualização registrada no site é 24 de maio de 2011.

75 No Facebook existe um grupo da Rede Povos da Floresta publicado por um fã: http://www.facebook.com/CentroYorenkaAtame?fref=ts.

${ }^{76} \mathrm{Um}$ dos polos de irradiação da Rede, o Centro Yorenka Ãtame (Saberes da Floresta) foi idealizado pela aldeia Ashaninka do Rio Amônia-Apiwtxa (Terra Indígena do Kampa). Situado no lado direito do rio Juruá, na frente do Município de Marechal Thamaturgo (Acre), o Yorenka Ãtame é um espaço de educação, formação, intercâmbio de práticas de manejo sustentável dos recursos da região, integrando, com o uso dos sistemas agroflorestais, as populações indígenas e não indígenas na recuperação de áreas degradadas. No Facebook, analisei também o grupo do Centro Yorenka Ãtame presente nesta rede social desde 30 de maio de 2012.
} 
sincrônica (em tempo real, a exemplo do bate-papo) e assincrônica (não imediata, como as mensagens, os comentários e a opção "curtir"). Ao inscrever-se nessa rede social, qualquer pessoa pode construir um perfil pessoal ou criar um grupo ${ }^{77}$ (aberto ou fechado, público ou restrito), cujas informações inseridas por seus membros ou amigos podem ser visualizadas por todos do perfil. As informações (toda e qualquer postagem, fotos, vídeos, textos, etc.) inseridas pelos usuários são organizadas automaticamente em uma linha do tempo (timeline) e, pela gestão de privacidade disponível em cada perfil, pode-se visualizar as informações postadas.

$\mathrm{Na}$ medida em que interagia com os conteúdos do site e dos perfis selecionados no Facebook, selecionei também o blog $^{78}$ do Centro Yorenka Ãtame e da Apiwtxa, a Associação dos Ashaninka do Rio Amônia (Acre), idealizadora do Centro Yorenka Ãtame, ambas organizações e polos de irradiação da RPF. Dos diversos grupos e comunidades da RPF, o Centro Yorenka Ãtame e a Apitwtxa foram os que pareceram mais atuantes, considerando esta atuação por meio dos eventos e posts relacionados à Rede. Tomei, então, como necessária, a estratégia de observar em profundidade essas organizações nas suas ações na RPF. Identifiquei outras linguagens midiáticas produzidas, como os vídeos produzidos pelos Ashaninka do Rio Amônia, entre eles "A gente luta mas come fruta" (Vídeo nas Aldeias, Ashaninka, 2007), bem como o vídeo de apresentação do Centro Yorenka Ãtame e do próprio coordenador da RPF, Ailton Krenak, e o registro audiovisual de uma Roda de Conversa ${ }^{79}$ entre os parceiros da Rede. Esse aspecto multimidiático aponta para a conformação de linguagens plurais com forte tendência audiovisual. Em novembro de $2012^{80}$, visitei tanto a aldeia Ashaninka Apiwtxa quanto o Yorenka Ãtame para a realização no Acre de entrevista com o seu coordenador, Benki Pianko, e conhecer de perto o processo de digitalização viveciando por eles.

77 Embora o o uso do Facebook seja aberto, é proibida a publicação de conteúdo associado a qualquer material pornográfico, racista ou que incentive a violência e a pedofilia. Para isso, existe uma equipe de segurança responsável pelo monitoramento dos conteúdos trocados entre os usuários. Tal ação é bastante controversa, pois, de um lado, pode inibir o crime, por outro, sobrepõe-se às normas de privacidade dos dados trocados entre seus usuários.

${ }_{78}^{78}$ O endereço do blog: http://saberesdafloresta.blogspot.br/.

${ }^{79}$ No site da Rede Povos da Floresta tem disponível o vídeo de uma "Roda de Conversa", um encontro realizado no Rio de Janeiro em outubro de 2009 entre todos os parceiros da Rede, no qual se discutiram as formas e estratégias de implantação e montagem dos equipamentos nos futuros Pontos de Culturas.

${ }^{80}$ Estive no Acre entre 23 de novembro e 05 de dezembro de 2012. Neste período fiquei cinco dias em Marechal Thaumartugo e uma noite na Aldeia Apiwtxa. Visitei os pontos de conexão da Rede Povos da Floresta: Yorenka e Apiwtxa e realizei entrevistas com Benki Pianko, sua esposa Célia, e o asessor técnico da Apiwtxa, Gleyson Teixeira (entrevista realizada presencialmente na sede da Associação Apiwtxa em Cruzeiro do Sul, Acre). 
Inicialmente eu havia selecionado para a investigação, a experiência sarda da Rede Social Sardinia People. Durante a realização do estágio sanduíche na Itália ${ }^{81}$, sob a co-orientação do sociólogo italiano Prof. Alberto Abruzzese, debrucei-me sobre essa experiência. Com arquitetura informativa interativa similar ao $\mathrm{Ning}^{82}$, essa rede social reelaborava os princípios da identidade regional sarda, como espaço virtual de diálogo entre os sardos, emigrantes e simpatizantes. Contudo, em vários momentos essa rede saiu do ar, da última vez, definitivamente dia 10 de setembro de 2012 (por falta de tempo e recursos de seus desenvolvedores). Embora eu tivesse realizado entrevista com o seu coordenador, decidi deixá-la de fora da análise comparativa. Esse episódio serviu para alertar sobre a efemeridade das experiências reticulares.

Enquanto desenvolvia o estágio sanduíche no exterior ${ }^{83}$, participei como ouvinte do terceiro encontro do programa de pesquisa do Institut de Recherche sur le Maghreb Contemporain com o tema "movimentos sociais online face às mudanças sócio-políticas e aos processos de transição democrática" (Tunis, 12 a 14 de abril de $2012)^{84}$. Lá conheci a doutoranda em ciências políticas da Universidade Autônoma de Madrid, Ângela Suarez Collado, cuja pesquisa trata das relações entre as Tecnologias de Informação e Comunicação e as rebeliões berberes durante a primavera árabe na África do Norte (2011).

$\mathrm{Na}$ ocasião, me encontrava às voltas com um dilema: a Rede Social Sardinia People estava fora do ar e, naquele momento, eu não tinha mais o meu circuito imersivo, meu campo de interação para que pudesse realizar o estudo comparativo

${ }^{81} \mathrm{O}$ estágio de doutorado no exterior foi realizado com bolsa Capes, durante o período de $1^{\circ} \mathrm{de}$ março a 31 de agosto de 2012, no IULM, Milão, sob a co-orientação do sociólogo da comunicação Prof. Alberto Abruzesse.

${ }^{82}$ Plataforma online (paga) que permite a criação de redes sociais.

${ }^{83} \mathrm{Na}$ oportunidade de estar na Europa, além de pesquisar na Itália, participei de eventos científicos e fiz pesquisa bibliográfica em Paris (França) e em Túnis (Tunísia).

${ }^{84} \mathrm{Com}$ a participação de diversos pesquisadores da região do Magrebe (Tunísia, Líbia, Argélia e Marrocos) e de outros países (Brasil, Espanha, Itália, França, Líbano, lêmen, Chile, Bélgica, Romênia, Grécia), o encontro pautou-se pelas principais interrogações em torno do papel das tecnologias de comunicação digital para a transformação da esfera pública, das instituições políticas, para a transição democrática dos países envolvidos na "Primavera Árabe" (2011-2012), nas revoltas das populações dos principais países árabes contra seus governos ditatoriais. A Tunísia, primeiro país árabe a se levantar contra a opressão de seu regime autoritário e a favor da democratização das suas instituições políticas, conseguiu derrubar o governo de Ben Ali (14 de janeiro de 2011) - embora situados em contextos diferentes e devido aos fatores políticos específicos - o mesmo ocorreu no Egito (11 de fevereiro de 2011), na Líbia (20 de outubro de 2011) e no lêmen (20 de fevereiro de 2012). Durante e após essas revoltas populares, se sobressaiu a mobilização de jovens e mulheres, até então novos sujeitos na cena política local, os quais, em muitos casos, faziam das redes digitais o lugar da expressão da opinião e da ação e coordenação política. 
com a Rede Povos da Floresta. Numa conversa realizada no hotel, o mesmo local onde se realizava o evento, Collado comentou sobre a experiência digital dos Cabilas na França por meio do portal Kabyle.com, o qual poderia me oferecer dados relevantes para pensar a reinserção do local por meio das redes digitais. Trocamos e-mails e, a partir de suas indicações bibliográficas, segui o rastro dos Cabilas na rede. De 15 de abril a 05 de julho de 2012, visitei frequentemente o portal Kabyle.com, cuja dinâmica envolve uma complexa arquitetura informativa com atualizações diárias sobre os povos berberes e cabilas na França, na Cabília (Argélia) e no mundo, contando com um espaço para venda de produtos, informações com a agenda de shows, manifestações, festas e vídeos com entrevistas e sondagens. Interagi conjuntamente com a página do grupo no Facebook e em sua conta do Twitter do grupo e do seu desenvolvedor Stéphane Arrami.

Além de imergir nessas arquiteturas informativas digitais, observei que os processos de digitalização dependem não só da aquisição de equipamentos e dispositivos (computadores em geral e celulares, etc.) e da inserção deles nesses ambientes informacionais digitais, como também de outro fator associado ao acesso à Internet, a conexão. Estabeleci, portanto, como critério de análise, o indicador de conectividade como uma característica fundamental para o fomento dos processos reticulares com os quais as produções midiáticas analisadas estão imbricadas. A conexão possibilita a articulação, a ligação e o vínculo entre o orgânico e o inorgânico, humano e não humano, mediadores culturais e dispositivos técnicos. A realização da conexão pelas interações híbridas faz da sua essência conectora a ponte de novas ramificações informativas que permitem as desterritorializações e reterritorializações, delineando novas paisagens midiáticas metaterritoriais e espacialidades comunicativas e, portanto, novos locais das culturas.

Com base nesta propriedade da rede, incluí à análise outro indicador, o de reticularidade, para cada experiência estudada, tomando como referência a morfologia dos modelos de rede de Paul Baran (1964). O primeiro, a rede centralizada, possui um nó difusor de informação, uma raiz arborescente. $O$ segundo, o modelo da rede descentralizada, caracteriza-se pela concentração de ligações (vínculos) de alguns nós com relação a outros. Por último, a rede distribuída, é a própria imagem do rizoma, de uma forma completamente descentralizada, em que a comunicação ocorre em vários pontos da rede: não há 
um único gerador dela, há uma multiplicidade de relações e uma heterogeneidade de nós e vínculos. Essa morfologia reticular ocorre em circunstâncias próprias e depende de cada tipo de arquitetura informativa digital, de sua relação com seus territórios e da dinâmica entre seus membros, o que veremos com mais acuidade nos próximos capítulos.

Embora eu tenha tido como ponto de imersão e observação as arquiteturas informativas digitais construídas pelas interações reticulares desses sujeitos e grupos, o uso da comunicação assincrônica (aquela que não ocorre em tempo real, a exemplo dos e-mails, SMS, etc.) e os "elos invisíveis" (aqueles que não aparecem visivelmente para o observador insider da rede) foram levados em conta na análise.

Ao exercer a "promiscuidade metodológica", fui experimentando e ajustando os procedimentos no decorrer da investigação. Dessa forma, outras propriedades comumente associadas à análise de redes sociais (ARS) foram incorporadas e reelaboradas durante a pesquisa, em termos de estrutura e dinâmica (AGUIAR, 2006), mas que diferem aqui de uma análise essencialmente estruturalista e frontal das redes digitais (DI FELICE, TORRES, YANAZE, 2012). Aquilo que comumente é chamado de "nó", associado a determinados "atores", aqui remetemos aos "atoresredes" independente de serem os impulsionadores dessas experiências reticulares. Em alguns momentos, na análise, por exemplo, o ecossistema dos grupos selecionados pôde constituir um "tecno-ator" para além de uma ação racional humana, lembrando que o horizonte teórico e metodológico no qual discorro é o da Teoria Ator-Rede de Latour. Pareceram-me pertinentes as inúmeras relações (elos, links) que em dado momento cada um desses tecno-atores, independente de serem humanos ou não, ou mesmo eventos ${ }^{85}$, podem estabelecer. São diversas e densas (muitas) ligações, associações e tipos variados de vínculos (ou de papéis de determinados atores-redes nas interações e nos fluxos informativos), reverberando uma dinâmica reticular específica.

O nível de conectividade, por exemplo, repercute em outro tipo de dinâmica das redes, o da intensidade, do ritmo de interconexão e fluxos informativos (a frequência da atualização da arquitetura da informação) e dos graus de participação de seus membros. Além disso, toda rede possui sua face visível observável a partir

\footnotetext{
${ }^{85} \mathrm{Um}$ evento divulgado na rede pode se tornar objeto de comentários e transformar-se em novos eventos reterritorializados. Tal fato aconteceu com os Cabilas, ocasionando a oportunidade de interagir com os membros da rede Cabila, para além do próprio portal Kabyle.com. Ver capítulo 4 desta tese.
} 
dos registros das trocas efetuadas por determinadas arquiteturas informativas (sites, blogs, grupos no Facebook, perfil no Twitter) e sua face invisível, "resultante do potencial multiplicador de cada nó para fora desse ambiente informativo" (AGUIAR, 2006), embora dele não esteja completamente externo e separado, mas imbricado informativamente por sua complementaridade.

Ao considerar, simultaneamente, esse conjunto de ações reticulares informativas amalgamadas nas/pelas arquiteturas informativas e seu nível de conectividade, me pareceu pertinente levar em conta a potencialização do empoderamento desses tecno-atores, tendo em vista 0 incremento $e \quad 0$ fortalecimento de contatos e apoios mobilizadores de recursos e de capital social ${ }^{86}$. Cada experiência estudada apresentou, de forma bastante circunstanciada, os modos pelos quais os elementos culturais, territoriais e midiáticos assumem uma determinada relevância também na autonomia e na autossustentabilidade da rede. Temos, nesse sentido, de um lado, o empoderamento dos tecno-atores com a mobilização e o acesso de capital social convertido para o grupo, no qual a rede digital se constitui; de outro, um empoderamento concernente à autossustentabilidade da rede.

Todos esses variados quesitos são dependentes das associações estabelecidas dentro e fora de cada experiência, numa perspectiva reticular e complexa e, por isso, parcial e situada, apontando que essas redes importam para seus formatos ecossistemas informativos híbridos dispostos por suas especificidades locais, culturais, históricas, imprevisíveis, efêmeras e finitas.

${ }^{86}$ Existe uma profusão de acepções teóricas em torno do conceito de capital social (COLEMAN, 1988; LIN, 1999; GRANOVETTER, 1973; BOURDIEU, 1998). Nos casos analisados, considero o capital social como recurso potencial mobilizado que circula e se estrutura nos fluxos informativos das redes sociais e digitais, conceituação inspirada naquela elaborada por Pierre Bourdieu (1998, p. 67): "[capital social é] o conjunto dos recursos reais ou potenciais que estão ligados à posse de uma rede durável de relações mais ou menos institucionalizadas de interconhecimento e de inter-reconhecimento mútuos, ou, em outros termos, à vinculação a um grupo, como o conjunto de agentes que não somente são dotados de propriedades comuns (passíveis de serem percebidas pelo observador, pelos outros e por eles mesmos), mas também que são unidos por ligações permanentes e úteis". 


\subsection{PRÁTICAS - AGENCIAMENTOS E RELAÇÕES}

Ademais de algumas estratégias analíticas para a imersão nas arquiteturas informativas digitais - sites, blogs, perfis e grupos presentes no Facebook - dessas experiências reticulares elegidas, existe outra camada a ser considerada, adjacente a essas arquiteturas: a das práticas e agenciamentos desses circuitos simbiônticos reticulares.

Os fluxos informativos trocados e suas relações inorgânicas, desde os softwares, as linguagens midiáticas empregadas, bem como as orgânicas, dos atores-redes envolvidos, do ambiente natural, reassociados nessas ações comunicativas, foram analisados como práticas, agenciamentos e relações dessas entidades. Procurei, portanto, associar esses elementos consorciados em suas relações, seus coletivos, no sentido de Latour (2012), subsidiados pela discursividade presente em seus ambientes informacionais, referenciais de práticas, de formas de "estar com", modo pelos quais são estabelecidas as conexões com seus atores-redes.

Essa dimensão "prática" prescinde da racionalidade da ação causal de um ente qualquer. O sociólogo francês Pierre Bourdieu em toda a sua obra posicionou e sublinhou a teoria da "prática" do conhecimento do social, um tipo de "conhecimento praxeológico", apreendendo-a na relação entre sujeito e estrutura, destituída de modalidades de conhecimento "subjetivista" - tomada pela referência do sujeito - e "objetivista", elaborada pelo estruturalismo, como explicação do mundo pelas estruturas sociais e sua determinação sobre os sujeitos. Dessa proposta "construtivista" fundamentada na superação da oposição entre subjetivismo e objetivismo, para a qual o sujeito ${ }^{87}$ é condicionado e condicionante (agente) das estruturas sociais nas quais se encontra situado, Bourdieu reelaborou os conceitos operacionais de habitus e campus pilares de sua teoria da prática.

Por habitus, referiu-se a um sistema de disposições, modos de sentir, de perceber, de fazer, de pensar, de compreender, que orientam a agir de determinado modo em uma circunstância específica. São adquiridos histórica e socialmente,

\footnotetext{
${ }^{87}$ Bourdieu prefere o termo "agente" a "sujeito" da estrutura, pela qual age e é por ela condicionado.
} 
aprendidos, internalizados, inconscientes, geradores e organizadores de práticas e representações, condicionantes e condicionadores das ações:

O habitus é o produto da experiência biográfica individual, da experiência histórica coletiva e da interação entre essas experiências. [...] Não é destino: preserva uma margem de líberdade ao agente, não, certamente, a liberdade do sujeito sartriano, mas a liberdade conferida pelas regras dominantes no campo em que se insere. Ele contém as potencialidades objetivas, associadas à trajetória da existência social dos indivíduos, que tendem a se atualizar, isto é, são reversíveis e podem ser aprendidas. (THIRYCHERQUES, 2006, p. 34)

Enquanto o campo externaliza e objetiva o habitus, formando um microcosmo no mundo social, o primeiro forma uma espécie de "campo de forças", "uma estrutura que constrange os agentes nele envolvidos, quanto um 'campo de lutas', em que os agentes atuam conforme suas posições relativas no campo de forças, conservando ou transformando a sua estrutura" (BOURDIEU, 1996, p. 50 citado por THIRY-CHERQUES, 2006, p. 35).

Dito isso, não se está aqui considerando a assunção de uma postura praxeológica nos termos bourdianos, mas, reconhecendo a importância de sua obra, a ideia de "prática" nesta tese assumiu outro significado. Não é o objetivo, aqui, fazer a análise das disposições dos agentes numa dada estrutura social ou campo - para ser breve (e correndo o risco da superficialidade) sobre os estudos elaborados pelo sociólogo francês. Não há, neste estudo, a aproximação com sua análise estrutural e sua pesquisa empírica (uso de técnicas de pesquisa qualitativas - entrevistas - e quantitativas - estatísticas). Por mais que se relativize a agência e a posição dos sujeitos inseridos em campos de força, mais ou menos autônomos, Bourdieu ainda se debruça sobre uma agencialidade humana, disposta ao jogo e às influências aleatórias desse sistema de predisposições (habitus). Não obstante, a reflexividade e a vigilância epistemológica nos caminhos e nas escolhas antes e durante a investigação são posturas compartilhadas durante todo o empreendimento da pesquisa que resultou neste trabalho.

Então, a que tipo de "prática" adotada mediante o percurso nos circuitos informativos eu me refiro?

A dimensão metodológica conformada aqui em uma "prática", em um exercício, descende daquela do agenciamento, do "entre", de uma tecno-ação 
contingente, destituída de uma causalidade, que se realiza com as interações e que podem ser rastreáveis na imersão das suas práticas comunicativas nas arquiteturas informativas $^{88}$. Embora algumas ações tenham impulsionado determinadas consequências, não são tomadas pela unicidade dos fatores relativos a determinados efeitos na composição reticular de suas localidades.

Nosso entendimento de agenciamento vai ao encontro daquele elaborado pelos filósofos franceses Deleuze e Guattari, e nos nutre de seu potencial revelador da dinâmica, da transitoriedade, do movimento e da multiplicidade de combinações que rompem os campos da representação e da ação orientada para fins. Neste sentido, a longa citação a seguir, comentário do Prof. Ciro Marcondes Filho (2009, p. 10) sobre o significado de agenciamento de Deleuze e Guattari, nos é iluminadora:

[...] nada existe que não sejam agenciamentos, que trabalham sobre fluxos semióticos, materiais, sociais, e que suprimem a divisão, por exemplo, entre campo de realidade (mundo), e um campo de representação (o livro), um campo de subjetividade (o autor) (O AntiÉdipo). Agenciamento é a soma ou o crescimento das dimensões numa multiplicidade que muda necessariamente de natureza à medida que aumentam suas conexões (p. 15). Ele é, em verdade, o complexo de todos os envolvidos: um dia, uma estação, uma neblina, o cenário, em suma, a totalidade participante (cf. p. 320, aplicado lá ao conceito de hecceidade).

Esses arranjos operam nos estratos, em zonas de descodificação dos meios (ambientes), de onde eles extraem ou constituem "territorialização": todo arranjo é, em primeiro lugar, territorial ( $p$. 629). Há sempre alguma territorialidade envolvida pelos arranjos de alguém, de uma pessoa, de um animal, como montagem "minha casa".

Como nos estratos, todos os agenciamentos possuem conteúdo e expressão, cuja articulação deve ser considerada. Se ele extrapola os estratos é porque a expressão nele já se tornou sistema semiótico, regime de signos, e o conteúdo já virou sistema pragmático de ações e paixões. Ou seja, mantendo a distinção estóica entre corpos e incorpóreos, os autores vêem a estruturação de dois tipos: agenciamento maquínico dos corpos e das paixões e agenciamento coletivo da enunciação.

Apreendo essa noção para reelaborar o agenciamento como relação de variadas materialidades, virtualidades, signos, numa organicidade perene e contígua, pela qual as interações do pesquisador insider, suas navegações, suas conexões com esses ambientes informacionais (e toda ordem de linguagens

${ }^{88}$ Como mencionado anteriormente, essa ideia de "rastreamento" das conexões se remete diretamente à Teoria do Ator-Rede, de Bruno Latour, como uma reapropriação no sentido ecossistêmico informativo, portanto, do habitar comunicativo, para a análise dos casos referidos. 
midiáticas, sejam elas textuais, imagéticas, audiovisuais) e seus atores-redes rendem sempre novas concepções, fadadas, assim, às mudanças da contingência e da historicidade.

Em consonância com Henrique Parra (2012, p. 18), em alusão à produção de subjetividades maquínicas edificadas nos agenciamentos técnicos, à luz de Guattari e Deleuze, entrevem-se modalidades dinâmicas e imprevisíveis de agenciamentos e relações com esses dispositivos técnicos:

\begin{abstract}
Ao indicar a íntima relação entre o uso dessas tecnologias e as transformações de nossa memória, inteligência, sensibilidade e subjetividade, Guattari não reduz nossa interação com as chamadas "interfaces maquínicas" a uma relação mecânica, pois o resultado deste encontro dá-se sempre num contexto tenso de disputa entre as possibilidades de criação ou captura subjetiva (Guattari, 2000). O pressuposto de um relativo grau de "abertura" da tecnologia deve-se, entre outras coisas, ao fato de que para Deleuze e Guattari (2005, p. 76) "o princípio de toda tecnologia é mostrar como um elemento técnico continua abstrato, inteiramente indeterminado, enquanto não for reportado a um agenciamento que a máquina supõe". Será então através dos agenciamentos que os elementos técnicos serão selecionados pelo phylum, dando expressão a uma determinada forma de relação.
\end{abstract}

Uma via de operacionalização analítica das interações com essas arquiteturas informativas, ultrapassa a generalidade das imbricações dos seus elementos diversos, humanos, técnicos, imagéticos, etc. Interessou-me compreender como esse ecossistema informativo se constitui e os modos pelos quais as relações são construídas por seus diversos tecno-atores, indicadores sensíveis de uma digitalização que excede o limite da soberania da ação humana.

\title{
2.3 NARRATIVAS E MEMÓRIAS
}

Compreendo "narrativas" nesta tese como disposições discursivas e imagéticas constitutivas das arquiteturas informativas digitais, viabilizadas por práticas comunicativas de enunciação formadoras dos índices de pertencimento e de autoidentificação. Diferentemente de uma "análise de conteúdo", vislumbrei um entendimento de uma forma discursiva criadora de espacialidades inerentes às 
próprias linguagens midiáticas. Como prática social, o discurso pode ser entendido como "uma forma em que as pessoas podem agir sobre o mundo e especialmente sobre os outros [...] [um modo de] significação do mundo, constituindo e construindo o mundo em significado" (FAIRCLOUGH, 1992, p. 91). As mídias, como os discursos, por elas vinculadas, são invariavelmente realidades sociais e discursivas, "ou seja, o discurso é a própria realidade" (SOARES, 2001, p. 26).

Por ser um dos objetivos desta tese analisar as transformações das expressões das performances identitárias e das formas comunicativas do habitar com o processo de digitalização, selecionei os discursos enunciadores de pertencimentos por meio das narrativas contidas nesses ambientes informacionais. A partir da recorrência de assuntos presentes em cada arquitetura informativa, tematizei os principais enunciados, traduzindo-os pelo modo como são articulados discursivamente, referindo-se a uma noção de espacialidade dessas culturas.

Estou requerendo aqui, então, uma camada de sentido num âmbito da linguagem criadora dos mundos que habitamos. Retomando, portanto, o filósofo alemão Heidegger, o Ser, o Ser-aí, o Dasein mora na linguagem, sendo essa moradia arredia a uma essência ou universalização, revelando o Ser em sua historicidade.

Esse modo de habitar nas mídias e na linguagem, interagindo com as tecnologias comunicativas que as compõem, empreende, discursivamente, formas de contemporizar suas identificações, mobilizadas por formas de narrar o passado. Pelas narrativas, presentes nesses ambientes informacionais, as memórias, reelaboradas para indicar-lhes pertencimentos, foram analisadas pelo seu sentido duplo: relembrar um passado vivido no presente e seus esquecimentos.

Substrato das performances identitárias presentes nos discursos das experiências reticulares estudadas, essas são, ao mesmo tempo, em suas diversas linguagens midiáticas, "lugares de memórias" ${ }^{\text {", }}$, como referido pelo historiador Pierre Nora (1993), o lugar onde o ato de relembrar "presentifica" e ressignifica determinadas tradições desses coletivos. Na acepção aqui utilizada esse "lugar" se

\footnotetext{
${ }^{89}$ Nas palavras da historiadora Margarida de Souza Neves (2004), os lugares da memória, no sentido elaborado por Pierre Nora, são, "primeiramente, lugares em uma tríplice acepção: são lugares materiais onde a memória social se ancora e pode ser apreendida pelos sentidos; são lugares funcionais porque têm ou adquiriram a função de alicerçar memórias coletivas e são lugares simbólicos onde essa memória coletiva - vale dizer, essa identidade - se expressa e se revela. São, portanto, lugares carregados de uma vontade de memória".
} 
corporifica na linguagem das mídias digitais e acolhe as especificidades socioculturais.

Seguindo igualmente o filósofo francês Paul Ricouer (2008), ao refletir sobre o passado enquanto narrativa de sua representação - fazendo dela um exercício de compreensão e explicação, pré-configurando o lugar e o tempo de sua produção e ininterruptamente significando sua abertura à interpretação daqueles que se debruçam nela -, fundamentei o modo de investigar as narrativas enunciadoras de alteridades e de memórias organizadas pelos seus coletivos nesses ambientes informativos digitais.

\subsection{INTERSUBJETIVIDADES E PESQUISA INSIDER}

A incursão nessas arquiteturas informativas me proporcionou, ao longo da imersão, o encontro não só com as espacialidades e as narrativas desses atoresredes, mas também pude lidar com aquilo que o filósofo alemão Hans-Georg Gadamer considera a "fusão de horizontes". A possibilidade de uma interpretação intersubjetiva, emanada do diálogo no encontro com os horizontes do intérprete e do interpretado, um aprender e apreender com as alteridades, sejam elas humanas e/ou não humanas.

Especificamente a intersubjetividade, nesta tese, fundamentou meu encontro (minha subjetividade de pesquisadora) com os atores-redes das redes por eles elaboradas. Tratando-a como categoria empírica, pois foi por meio dos encontros, do estabelecimento de contatos, da interpessoalidade, proporcionados pelas entrevistas abertas e semiestruturas com os desenvolvedores e coordenadores das iniciativas reticulares, que pude imergir naquilo que os impulsionou, nas suas interpretações sobre esses empreendimentos e nas informações mais gerais que contribuíram para que eu pudesse compreender melhor essas experiências. Tudo isso me ajudou a perspectivar as relações e as associações dos diversos atores, humanos ou não, nesses ecossistemas informativos.

Muito embora não seja o objeto desta tese a análise em profundidade das intersubjetividades, é pertinente vislumbrar terem sido os processos comunicativos 
intersubjetivos ${ }^{90}$ envolvidos nos encontros com essas alteridades, os ocasionados dentro e fora das redes digitais, que proporcionaram uma produção do conhecimento composta pelo estranhamento e pela dialogia ${ }^{91}$. Isto é, tais posições pesquisadora, pesquisado, objeto - tiveram graus relativos no decorrer da pesquisa. Minha posição foi sendo reelaborada e renegociada na medida em que interagia com essas experiências reticulares. Tanto o estranhamento quanto a familiaridade foram momentos constitutivos do processo de conhecimento decorrente da imersão e dos diálogos.

Portanto, meu posicionamento enquanto pesquisadora insider, a problematização do meu lugar nas redes digitais e a minha relação com esse contexto e com meus interlocutores me proporcionaram repensar os procedimentos metodológicos da observação, da descrição e da produção de um relato como exercício de uma narrativa resultado desse horizonte intersubjetivo.

Obviamente tal prática assemelha-se ao exercício etnográfico realizado pela antropologia, mas dele se difere. Embora, nos estudos do campo da cibercultura ${ }^{92}$, a abordagem etnográfica venha sendo reapropriada e validada como método de pesquisa qualitativa para estudos empíricos sobre culturas, práticas comunicacionais

${ }^{90}$ Tais "processos comunicativos intersubjetivos" não são intercambiáveis com a "ação comunicativa" nos termos de Jürgen Habermas (2012), referenciada por uma ação racional e crítica de uma comunicação intersubjetiva, compartilhada por uma concepção linguística da racionalidade, governada por normas consensuais. Por conseguinte, sua teoria comunicativa funciona como uma teoria crítica da sociedade, na qual a ação comunicativa prescreve um consenso normativo entre os indivíduos, que agem socialmente e comunicativamente em busca de um entendimento.

${ }^{91}$ Uma dialogia inspirada na elaborada pelo pensador russo Mikhail Bakhtin. Ao retomar o significado da teoria da linguagem dos textos literários, um horizonte de diálogo polifônico, constituído pela comunicação interativa dos sujeitos, em que os enunciados trocados são intrínsecos ao Outro e ao contexto ao qual a mensagem se destina, a dialogia aqui assume uma dimensão de interação com alteridades situadas em seus ambientes informativos, locais e circunstanciais.

92 A cultura contemporânea marcada pelas interações com as tecnologias comunicativas digitais promove aquilo que Pierre Levy (1999) e Andre Lemos (2004, p. 2) chamam de cibercultura, novas dinâmicas socioculturais de compartilhamento, distribuição, cooperação e apropriação dos bens simbólicos. Embora o termo não seja empregado por todos aqueles que estudam essas transformações, com o aparecimento das mídias digitais, no Brasil, o termo "pegou" na nomeação da mais importante instituição que agrega os principais estudiosos brasileiros do tema do digital na comunicação. A Associação Brasileira de Pesquisadores em Cibercultura - ABCIBER, fundada em 2006, conta como membros efetivos a própria Adriana Amaral, André Lemos, Lucia Santaella, Eugenio Trivinho, Simone de Sá, Vinícius Pereira, Theophilos Rifiotis, Raquel Recuero, Massimo Di Felice, entre outros, vem tornando-se um espaço promissor para a congregação de novos pesquisadores voltados à temática, delineando um lugar específico dentro dos estudos comunicativos, diante dos seus tradicionais lugares de legitimação e divulgação, a exemplo da Compós (Associação Nacional dos Programas de Pós-Graduação em Comunicação) e da Intercom (Sociedade Brasileira de Estudos Interdisciplinares da Comunicação). Obviamente, esses são lugares tradicionais de performatização do campo científico dos estudos da comunicação no Brasil, voltados para as investigações principalmente das mídias de massa, seus efeitos e significações, os quais espelham também os conflitos e as disputas políticas no interior dessa comunidade científica. 
e sociabilidades emergentes nas redes digitais, é preciso levar em conta as especificidades do digital (tomado aqui por essa expressão genérica), precursor de novos campos de estudo, de instrumentos de pesquisa e, simultaneamente, do local do acontecimento investigativo.

No Brasil, a pesquisadora Adriana Amaral vem pontuando o debate sobre a etnografia e a pesquisa em cibercultura a partir do diálogo com os principais estudiosos e seus trabalhos no campo dos estudos sobre essas novas sociabilidades (SA, 2002; HINE, 2000, 2005, 2009; MONTARDO e ROCHA, 2005; NATAL e VIANA, 2008; KOZINETS, 2010), incluindo-se entre eles (AMARAL, 2008, 2009). Parto de três trabalhos seus para apresentar e tecer brevemente algumas considerações sobre essa prática: Autonetnografia e inserção online: o papel do pesquisador-insider nas práticas comunicacionais das subculturas (2009); Etnografia e pesquisa em cibercultura: limites e insuficiências metodológicas (2010) e o capítulo por ela elaborado, "Abordagens etnográficas" situado na segunda parte, "Apropriações metodológicas", do Livro Métodos de pesquisa para a Internet (FRAGOSO; RECUERO; FRAGOSO, 2011). A partir da leitura dos principais autores da temática, a pesquisadora perscruta também suas próprias pesquisas ${ }^{93}$ na condução de uma análise da apropriação da etnografia na cibercultura, contextualizando-a, informando os liames do debate nos últimos anos e refletindo acerca dos termos empregados.

Para a Christhine Hine (2000), responsável pelo termo, a etnografia do virtual constrói o campo de análise pela reflexividade e subjetividade. Condicionada pela inseparabilidade do momento on-line e off-line, esse tipo de etnografia inclui decisivamente a participação do pesquisador na imersão e na interação.

Em meados dos anos 1990, surge o termo "netnografia", neologismo criado por Robert V. Kozinets (2010) para diferenciar a utilização do método etnográfico nos estudos dos ambientes digitais, "seja em termos de coleta de dados, seja em termos de ética de pesquisa e análise, uma vez que o presencial e as experiências são de naturezas diferenciadas" (AMARAL, 2010, p. 3), embora nesses estudos comunicativos tais ambientes (on-line e off-line) estejam inter-relacionados. Kozinets menciona quatro procedimentos relacionados à prática netnográfica: a entrée

\footnotetext{
${ }^{93}$ Adriana Amaral, a partir de suas experiências pessoais, desenvolveu pesquisa insider mediante os usos, as apropriações e os consumos Web em diversas plataformas sociais por parte dos membros da subcultura eletro-industrial. (AMARAL, 2009). Amaral, além de proeminente pesquisadora de sub e ciberculturas, é DJ, participante ativa das cenas eletro-industriais no Brasil e no exterior.
} 
cultural; a coleta e análise de dados; a ética de pesquisa; o feedback e a checagem de informações com os membros do grupo. Com exceção da entrée, tais etapas não ocorrem necessariamente nessa ordem.

Contudo, a difusão do termo esteve fortemente associada às pesquisas de marketing, no uso de monitoriamento de comunidades on-line e hábitos de consumo. Diferente dessa aplicação voltada ao mercado, a pesquisadora Simone de Sá (2000, 2001), pioneira no país em adotar a netnografia, no caso do estudo das comunidades carnavalescas on-line, o samba carioca em rede, almejando uma pesquisa experimental, "detalhista e interpretativa" estabelecida pela "negociação construtiva" entre o pesquisador e o pesquisado durante relações concretas, intensivas e "carnais", permeada por sentimentos, emoções, afetos, surpresas e incertezas nos encontros, festas, ensaios de quadra e desfiles durante o Carnaval (ROCHA e MONTARDO, 2005).

Ao revelar um grau de preocupação nas possíveis influências do pesquisador nos resultados da pesquisa, Kozinets (2007, p. 15 citado em AMARAL, 2009, p. 19) sugere também o conceito de autonetnografia "para o maior nível de proximidade entre o pesquisador e os sujeitos observados, proporcionando imersão, internalização, consciência de alteridade e engajamento nas comunidades. Existe uma série de trabalhos valendo-se da autoetnografia, que expõem a inserção do pesquisador no ambiente e os motivos pessoais que o levaram a escolher determinadas comunidades, descrevendo, assim, as dificuldades e aberturas durante a pesquisa (AMARAL, 2009, p. 20). Nesse sentido, os aspectos biográficos do pesquisador considerados na trajetória da pesquisa remetem ao grau de proximidade dele com os grupos ou comunidades observadas. Consequentemente, o compartilhamento de gostos e de cenas pode elevar o grau de dificuldade do pesquisador no momento da elaboração de suas análises, o que dependerá do seu nível de envolvimento e grau da sua capacidade de estranhar aspectos familiares da sua posição insider. De antemão, a (im)parcialidade da pesquisa e os aspectos subjetivos a elas relacionados são fatores constituintes de todo e qualquer processo de conhecimento, em que não existe uma posição neutra e asséptica do pesquisador.

Outras terminologias, tais como etnografia digital (WESCH, 2001), webnografia (RYAN, 2008) e ciberantropologia (HARAWAY, 1991; ESCOBAR, 1994; HAKKEN, 1999), são recorrentes, voltadas a explorar e expandir as possibilidades 
do método etnográfico relacionado às diversidades de estudos do digital e suas implicações para a problematização do humano.

Por outro lado, a antropologia também passou a flertar com o ciberespaço, definindo sobremaneira sua inserção dentro do campo das comunidades e interações digitais. O antropólogo Theophilos Rifiotis (2010, p. 15) evidencia os dilemas de ordem teórica e metodológica que exigem uma revisão das modalidades clássicas de pesquisa etnográfica: "Os estudos das interações sociais mediadas por computador tem se mostrado um campo fértil para a pesquisa dos fundamentos da sociabilidade e tem sido um vetor importante para a análise crítica do trabalho antropológico". Consequentemente, o estudo dessas interações estaria, portanto, propiciando a retomada dos fundamentos da disciplina, pela via interrogativa de como se dão as relações no ciberespaço, retomando as noções principais da pesquisa antropológica: campo, trabalho e diário de campo, pesquisa participante e noção de entrevista mediada por computador, cujas problematizações no interior da disciplina estão ocasionando "uma rica reflexão com significativos impactos sobre os fundamentos da produção de conhecimento antropológico" (RIFIOTIS, 2010, p. 15).

Dessa forma, o trabalho de campo circunscreve modos de socialização dos "nativos", "usuários", evocando modos de "socialização no ciberespaço", "um conjunto complexo de afinidades, interesses, práticas e discursos que ocorrem como um processo de iniciação no qual interagem experiências online e offline" (RIFIOTIS, 2010, p. 22), pelo qual as experiências ocorrem nas interfaces no contato com os comandos, possibilidades, opções e limites do software. O próprio diário de campo, instrumento da pesquisa antropológica, não está reduzido ao simples tomar notas. $\mathrm{Na}$ incursão realizada nas redes digitais o relato é retomado como uma descrição detalhada das interações e dos respectivos mediadores. A observação participante permite uma melhor compreensão sobre o ato comunicacional no ciberespaço (situação de copresença) e põe a "necessidade de uma reflexão sobre as mediações da comunicação por meio dos computadores e softwares e os códigos compartilhados, sejam eles verbais ou corporais ou outros" (RIFIOTIS, 2010, p. 21).

Desse apanhado, adotei alguns dos procedimentos salutares para viabilizar minhas deambulações nos circuitos imersivos das redes. Porém, abro mão de uma definição antecipatória, de uma titulação autorreferencial, qualquer que seja, etnografia do virtual, netnografia, ciberantropologia, webgrafia, etc. Remixei e apropriei-me dos procedimentos citados conforme o próprio percurso realizado. 
$\mathrm{Na}$ utilização de algumas estratégias, o relato, a prática do registro das incursões nessas arquiteturas informativas, informou a própria parcialidade do conhecimento produzido. O uso de um diário de campo serviu para perspectivar e situar minha posição enquanto pesquisadora insider que compartilha do contexto provisoriamente $\mathrm{e}$ interage com os coletivos interlocutores desses espaços informacionais. Embora, nos estudos desenvolvidos em contextos digitais (HODKINSON, 200594; AMARAL, 2009), a pesquisa insider venha sendo conceituada pelo alto nível de envolvimento e compartilhamento sociocultural do pesquisador com os grupos analisados, além dos aspectos biográficos dele recorrentes na trajetória da pesquisa, minha disposição insider primou-se, sobretudo, pelo compartilhamento do ambiente on-line, pelo encontro intersubjetivo e pela narrativa em primeira pessoa dessa experiência. De antemão, a saber, todos os casos selecionados e analisados não eram conhecidos por mim e eu tampouco compartilhava de seus contextos socioculturais.

Diante do encontro intersubjetivo tanto nas arquiteturas informativas quanto nas conversas com os meus interlocutores (atores-redes) eu assumi diversos papéis, além daquele de "pesquisadora" interessada em investigar as experiências realizadas por eles. Digo isso porque desses encontros, ora fui vista por eles como a "pesquisadora da USP" ao investigar a RPF, ora fui a "brasileira doutoranda" com os meus interlocutores cabilas/berberes do Portal Kabyle.com. Também perfomatizei o ser pesquisadora (obviamente essa é "uma" parte de minha pessoa). Esse "a" sublinha justamente a minha condição não só de uma pessoa com uma posição na universidade (doutoranda), mas também de gênero e nacionalidade. De modo geral, para aquilo que me propunha, ser identificada como mulher e brasileira ajudou positivamente no contato com esses interlocutores e seus ambientes informativos.

Assim, de modo diferenciado, dada a configuração de cada ambiente informacional, habitei nas arquiteturas do site da Rede Povos da Floresta e do Portal Kabyle.com. Todos os conteúdos divulgados dessas arquiteturas não eram materiais sensíveis - os quais exigem do pesquisador uma postura ética de preservação dos nomes dos entrevistados em decorrência da faixa etária dos participantes, de sua

\footnotetext{
94 Hodkinson analisou as subculturas góticas da qual faz parte utilizando os procedimentos da pesquisa insider, partindo da análise de sua própria trajetória dentro desses ambientes e adotando a pesquisa insider "enquanto um conceito não-absoluto intencionado para designar aquelas situações caracterizadas por um grau significante de proximidade inicial entre as locações socioculturais do pesquisador e do pesquisado" (HODKINSON, 2005, p. 134 citado em AMARAL, 2009, p. 20).
} 
profissão, das temáticas debatidas, etc. (AMARAL, 2010, p. 4). Os entrevistados, inclusive, eram todos maiores de idade, pessoas públicas com papel relevante e estratégico em suas redes ${ }^{95}$.

Dessa maneira, meu grau de inserção nas redes, as imersões e as reflexões produzidas sobre o processo de digitalização desses coletivos foram discorridos, descritos em um diário de pesquisa editado no Word (sim, software proprietário) e frequentemente atualizado com as leituras teóricas realizadas posteriormente ${ }^{96}$. Com ele anotei as impressões, buscando dar sentido às minhas hipóteses e repensar reflexivamente (o pleonasmo é intencional) as formas pelas quais a localidade se digitaliza e ganha novas significações.

Portanto, a perspectiva reticular vislumbrada, imersiva e dialógica, parte do ponto de vista perspectivo e reticular, situado e parcial, e orientou o meu "lançar-se" às redes digitais, em sua complexidade fértil, a partir dos dois casos distintos. Essa "seleção" de casos, de redes, não cinde as conexões delas resultadas, porque no processo de análise procurei evidenciar as inter-relações simbióticas dos coletivos com suas culturas, em interface direta com suas produções midiáticas digitais e seus metaterritórios.

Da epistemologia adotada ao percurso percorrido, estamos em diálogo direto com perspectivas e posturas de pesquisa experimentais e imprevisíveis que acontecem, dado seus "dinamismos reticulares (coletivos, tecnologia e territórios) que se articulam criando ecossistemas e uma específica condição habitativa, cuja narração constituirá o particular desafio interpretativo e lingüístico do pesquisador mais que participante: conectado e hóspede" (DI FELICE; TORRES; YANAZE, 2012, p. 183).

De fato, os processos reticulares de digitalização vivenciados pelos casos estudados não remetem a uma similitude, ao contrário, apontam para modos

\footnotetext{
${ }^{95}$ No total, foram realizadas sete entrevistas registradas, abertas e semiestruturadas. Da Rede Povos da Floresta, entrevistei Benki Pianko e sua esposa, Célia; Ailton Krenak, Gal Rocha e o assessor técnico da Apiwtxa, o sociólogo Gleyson Teixeira. Do Portal Kabyle.com, conversei com seu desenvolvedor, Stephane Arrami, além de conversar com Brahim Slimani, presidente da Associação Cultural Apulée, na França.

96 Após a qualificação do projeto, em 19 de agosto de 2011, publiquei o blog http://localdigitaldasculturas.wordpress.com/, no intuito de constituir um diário on-line da pesquisa, procedimento razoavelmente difundido em pesquisas no ambiente digital, mas que, no meu caso, acabei abandonando. Os motivos só se tornaram claros posteriormente. Eu não consegui manter uma frequência de atualização e, antes de registrar publicamente os posts, me senti na obrigação de manter a acuidade na divulgação dos dados. Pretendo retomá-lo após a defesa da tese para divulgar o material audiovisual produzido durante a pesquisa.
} 
variados, que me levaram à realização da comparação. Busquei, assim, durante e após o estudo aprofundado dessas experiências, assimilar suas semelhanças e diferenças para designar "expressões" e "tipos" de local digital das culturas.

Para tal, a comparação ${ }^{97}$ apresentou-se como recurso para além do método, uma postura apta a ampliar os horizontes semânticos, conforme pensado por Roberto Cardoso de Oliveira (1998). A possibilidade de discernir essas semelhanças e diferenças rende novas compreensões sobre os processos locais que se deslocam e se reelaboram digitalmente pela conectividade, tornando-se uma postura fértil para interpretá-las e repensá-las enquanto processos glocais contemporâneos.

Mais uma vez afirmo que o eixo de análise da interação reticular entre coletivos e ambientes informativos expõe a permeabilidade interna (das redes a serem analisadas) e externa (dos sistemas informativos e das conexões por elas realizadas) dos processos comunicativos em rede. Sua dinâmica encontra-se na 'relação' entre as diferentes materialidades, na contiguidade de elementos orgânicos e inorgânicos em que os fluxos informativos produzidos mudam o contexto de comunicação entre as pessoas, além da estrutura social e da noção de "lugar" (MEYROWITZ, 1995). Dessas práticas e estratégias midiáticas, as relações delas decorrentes borram as distinções entre on-line/off-line, fazem com que "seguir as práticas e os [tecno]atores sociais' em suas performances" considere "não apenas a dimensão simbólica, mas também a dimensão material no qual o campo é definido durante a pesquisa" (FRAGOSO et al., 2011, p. 44).

Saliento, finalmente que a observação, a descrição e a interpretação insider, da tríade simbiôntica, das arquiteturas informativas digitais (das mídias nativas reticulares), de suas narrativas e práticas (agenciamentos), forneceram o estrato interpretativo e tradutório das paisagens midiáticas desta tese.

\footnotetext{
${ }^{97}$ Aqui nos valemos do método comparativo como meio de expressar, compreender e analisar as dessemelhanças e as similitudes entre os casos analisados. Tal método é bastante utilizado pelos cientistas políticos para definir "regularidades" e "padrões" entre fenômenos macro e micro políticos (SARTORI, 1994) a partir da descrição dos dados empregados na formulação de teorias explicativas, modo não empregado nesta tese.
} 


\section{PARTE II}

A Rede Povos da Floresta e a ecologia xamânica comunicativa Ashaninka 


\begin{abstract}
Desde que os sistemas vivos em todos os níveis são redes, devemos visualizar a teia da vida como sistemas vivos (redes) interagindo à maneira de rede com outros sistemas (redes). Por exemplo, podemos descrever esquematicamente um ecossistema como uma rede com alguns nós. Cada nó representa um organismo, o que significa que cada nó, quando amplificado, parece, ele mesmo, uma rede. Em outras palavras, a teia da vida consiste em redes dentro de redes. Em cada escala, sob estrito e minucioso exame, os nós da rede se revelam como redes menores. Tendemos a arranjar esses sistemas, todos eles aninhados dentro de sistemas maiores, num sistema hierárquico, colocando os maiores acima dos menores, à maneira de uma pirâmide. Mas isso é uma projeção humana. Na natureza não há "acima" ou "abaixo", e não há hierarquias. Há somente redes aninhadas dentro de outras redes. [...] Ecologia é redes...

Entender ecossistemas será, em última análise, entender redes.

Fritjof Capra (1996, p. 25)
\end{abstract}

Quem se reúne, quem fala, quem decide em ecologia política? Conhecemos agora a resposta: nem a natureza, nem os humanos, mas os seres bem articulados, as associações de humanos e não humanos.

Latour (2004, p. 157)

A Rede Povos da Floresta é composta por um conjunto de redes que forma um ecossistema social complexo feito de redes de circuitos informativos, de redes de pessoas e de povos, redes de saberes locais, redes de biodiversidade (floresta), rede de territórios e de tecnologias midiáticas digitais. Isto é, esse conjunto de "rede de redes" constitui a Rede Povos da Floresta como um tipo social formado por diversos atores-redes ${ }^{98}$, humanos e não humanos, em contínua relação entre si, cujo dinamismo articula o devir emergente dessas arquiteturas articuladas na relação entre cultura, mídias digitais, territórios.

Nesta segunda parte, portanto, descrevo e analiso os ecossistemas reticulares e atópicos da Rede Povos da Floresta (RPF) e de um dos polos dessa rede, o Centro Yorenka Ãtame da Associação Ashaninka Apiwtxa do rio Amônia (AC). Para isso, subdividi esta parte em dois capítulos respectivos, o terceiro e quarto, em continuidade à numeração precedente.

No terceiro capítulo, o primeiro desta segunda parte, apresento brevemente a história do movimento social dos seringueiros que originou a Aliança Povos da Floresta e sua reatualização com a RPF. Em seguida, descrevo as redes dos circuitos informativos, primando pelas interações com suas arquiteturas informativas;

\footnotetext{
${ }^{98}$ Novamente, recordo ao leitor que a noção "ator-rede" refere-se àquela elaborada por Bruno Latour (2004), sendo tudo aquilo e/ou aquele que age na rede, humano ou não humano. Tal ação não é isolada e não pode ser determinada por suas causas e/ou efeitos.
} 
posteriormente, pontuo cronologicamente seu desenvolvimento, mostrando sua conformação reticular feita de pessoas, de organizações, de mídias digitais e do ecossistema da Floresta.

No quarto capítulo, focalizo a análise em um dos polos de irradiação da Rede Povos da Floresta, o Centro Yorenka Âtame, resultado da ecologia xamânica e comunicativa Ashaninka. Busquei, assim, associar essa rede de "tecno-atores" (ou atores-redes) e seu meio ambiente, bem como sua cosmologia xamânica, mostrando porque esse Centro e a atuação dos Ashaninka se destacam dentro dessa ação comunicativa reticular. Para isso, apresento as especificidades históricas e culturais do povo Ashaninka, a reatualização de seus sistemas de trocas tradicionais com a digitalização e a interação deles com os dispositivos técnicos comunicativos. Na última parte, encerro com a interpretação do significado dessa digitalização, que se caracteriza como uma complexa arquitetuta de rede de redes, referindo-me à tríade simbiôntica. 
A REDE POVOS DA FLORESTA

\begin{abstract}
A produção cultural das comunidades da floresta - índios, quilombolas, ribeirinhos e populações extrativistas - exige uma condição dada pelo meio ambiente que define sua territorialidade e essa territorialidade não é apenas física, é o conjunto das relações simbólicas do povo que ocupa aquele território e mantém suas tradições culturais desenvolvidas naquele ambiente ou lugar.

$[\ldots]$

Uma função da Rede Povos da Floresta é alimentar o fluxo entre estas comunidades de informação e grupos de apoio e solidariedade a ponto de não deixar nenhum furo nessa rede. Canal franco, aberto, para intercâmbio. Via de trânsito rápido e de mão dupla.

A Rede Povos da Floresta é uma iniciativa voltada para o fortalecimento institucional das ações de todas essas comunidades diante da pressão enorme que sofrem para saírem de seus territórios de origem.
\end{abstract}

Ailton Krenak (RPF, 2004) $)^{99}$

Quando se está no norte, na parte amazônica, o povo costuma dizer "escute o chamado da Floresta" para se referir ao convite que esse ecossistema faz para que se considere a sabedoria de seus seres. Esse chamado da Floresta tem sempre algo a dizer, embora não seja "dito" imediatamente para aquele(a) que o escuta. Para mim, esse chamado se constituiu de uma aproximação realizada no sentido de compreender o processo de digitalização vivenciado por esses povos, resultado do entrelaçamento simbiótico deles com as mídias digitais e seus territórios.

Neste capítulo, portanto, compartilho com os leitores meu percurso entre esse conjunto de redes. Meus ouvidos e olhos se voltaram para os circuitos da Rede Povos da Floresta (RPF). Após eu ouvir seu chamado em suas arquiteturas informativas e ler os diversos livros e artigos sobre esses povos e essa região, mergulhei nos seus circuitos e fui ao Acre conversar com Benki Pianko, coordenador do Centro Yorenka Ãtame, e outros participantes da Rede, entrando, assim, nos diversos níveis de suas tramas.

99 Disponível em: http://redepovosdafloresta.org.br/exibePagina.aspx?pag=45\&pagTipo=h. Acesso em: 15 set. 2011. 
As redes informativas das arquiteturas informativas digitais somam-se às redes de pessoas, às redes da Floresta e sua biodiversidade, feita de ecossistemas interagentes: flora, fauna, rios, etc. Em todo o momento, minhas interações moldam uma rede de contatos que é minha rede de interações conectivas. Uma arquitetura, portanto, viva, que reage às minhas ações e perguntas e toma a forma gráfica do meu relato. Consegui narrar a Rede Povos da Floresta só quando eu a habitei e pelas minhas interações eu a reconstruí.

Para narrar essa experiência imersiva, dialógica e atópica, dividi esse capítulo em três partes. Na primeira, apresento a história do movimento social dos seringueiros, que originou a Aliança Povos da Floresta e a sua reatualização com a Rede $^{100}$. Em seguida, adentro-me em seus circuitos informativos digitais, primando pelas interações com a sua arquitetura informativa principal, o site Rede Povos da Floresta. Por fim, na terceira parte, amplio o olhar, apresentando a linha do tempo do desenvolvimento da Rede, inserindo, ao longo dessa parte, os trechos da entrevista que realizei com Ailton Krenak, coordenador da RPF, para melhor compreendermos os meandros dessa experiência reticular, ou seja, o processo de digitalização impulsionado pelos atores-redes envolvidos.

\subsection{A ALIANÇA E A REDE POVOS DA FLORESTA}

A Rede Povos da Floresta nasceu em setembro de 2003 da revitalização da Aliança dos Povos da Floresta, um movimento social e ambiental muito forte no Acre na década de $1980^{101}$, que contou com a participação de povos indígenas, ribeirinhos e seringueiros, resultado da liderança de Chico Mendes ${ }^{102}$ e da participação de líderes indígenas, entre eles Ailton Krenak.

\footnotetext{
100 Neste capítulo, toda ocorrência da palavra "Rede" (em maiúscula) refere-se à Rede Povos da Floresta.

${ }^{101}$ Para consultar a história dos seringais e do movimento dos seringueiros, ver: CUNHA, , M. C. e ALMEIDA, M. B. (Orgs.). Enciclopédia da Floresta - o Alto Juruá: práticas e conhecimentos das populações. São Paulo: Companhia das Letras, 2002. Ainda: ALMEIDA, M. B. Direitos à floresta e ambientalismo: seringueiros e suas lutas. Revista Brasileira de Ciências Sociais, São Paulo, v. 19, n. 55, p. 33-53, 2004.

102 Francisco Alves Mendes Filho, conhecido por Chico Mendes, nasceu em Xapuri, Acre, em 1944. Filho de migrantes cearenses vindos à procura de oportunidade no trabalho do seringal, aprendeu a ler aos vinte anos. Em 1975, começa a atuar no Sindicato dos Trabalhadores Rurais de Brasiléia e, nos anos seguintes, participa ativamente dos empates, das ações diretas contra a derrubada da
} 
A história do movimento tem origem no processo de ocupação territorial e na inserção econômica local no contexto mundial. Dois ciclos econômicos de comercialização mundial da borracha (1870-1912; 1943-1945) lançaram a região do Alto Juruá $(A C)$ e de todo o Acre no mapa do comércio internacional. Desde 1850, os índios forneciam a borracha para comerciantes que exploraram a região. Com a invenção da vulcanização por Goodyear, em 1870, e o aumento da produção em larga escala para pneus de bicicleta e, posteriormente, de carros, houve a explosão da procura, demanda que os índios não conseguiam mais suprir. Iniciou-se, então, a chegada dos nordestinos na região da Amazônia. Foram cerca de sessenta mil, trazidos por casas exportadoras e donos de seringais, trabalhando em regime duro.

Com a produção de seringa na Malásia, o preço internacional da borracha despencou, ocasionando uma grave crise na região, só remediada com a alta dos preços da goma durante a Segunda Guerra Mundial. Nessa época, o Brasil passa a suprir os exércitos dos Aliados, pois os japoneses haviam cortado o fornecimento da borracha asiática. Na oportunidade, o governo brasileiro lança uma nova campanha, levando cinquenta mil pessoas, "os Soldados da Borracha", para a floresta amazônica. Nos anos seguintes, após o fim da guerra, o governo federal adquiriu e manteve o monopólio de comercialização da borracha, como medida protecionista, visando evitar uma crise na região parecida com a ocorrida após o primeiro ciclo da borracha devido à concorrência asiática.

Em 1986, com o fim do programa de incentivo à produção da borracha do governo federal, os donos dos seringais começaram a investir na extração da madeira e na produção pecuária. Principia o desmatamento indiscriminado na região. Em decorrência disso, os seringueiros começam a se organizar e realizam os

floresta. Ajuda a fundar o Sindicato dos Trabalhadores Rurais de Xapuri, ingressando em seguida no Partido dos Trabalhadores. Liderou o primeiro Encontro Nacional dos Seringueiros, fundando o Conselho Nacional dos Seringueiros; na oportunidade, propõe a "União dos Povos da Floresta" para a defesa da floresta amazônica. Em 1987, ao receber a vista de representantes da Organização das Nações Unidas no Acre, denuncia o desmatamento da região realizado pelos fazendeiros que tinham projetos financiados por bancos internacionais. Leva suas denúncias ao Senado dos Estados Unidos e ao Banco Interamericano de Desenvolvimento (BID). Este último cancela o financiamento aos fazendeiros envolvidos nos desmatamentos. Chegando ao Brasil, percorre o país realizando seminários e palestras sobre a gravidade da destruição da Amazônia e a violência dos fazendeiros contra os seringueiros e as outras populações locais. Recebe inúmeros prêmios internacionais. Em 1988, é assassinato em sua casa, em Xapuri, a mando dos fazendeiros Darly Alves da Silva e Darcy Alves Ferreira. A atuação de Chico Mendes internacionalizou a questão da Amazônia, mostrando não só ao mundo, mas principalmente ao Brasil, as consequências do desenvolvimento da Amazônia. 
empates $^{103}$, "ações coletivas para impedir a derrubada de florestas, a qual era precedida pela expulsão de seringueiros e apropriação de terras" (ALMEIDA, 2004, p. 50). Além de buscar manter a floresta em pé, o grupo propôs a criação de Reservas Extrativistas, "a transformação de grandes áreas de floresta em áreas públicas para uso coletivo segundo práticas tradicionais" (ALMEIDA, 2004, p. 36). Ainda que essa opção extrativa tenha sido permeada por diversas controvérsias, que envolvem o desenvolvimento da região associado aos interesses nacionais e internacionais e a percepção do extrativismo como economia 'inviável', destaca-se que o movimento dos seringueiros nasce e se fortalece pela capacidade deles de constituírem redes de apoios, extrapolando a própria localidade e ganhando respeito internacional e nacional ${ }^{104}$. Foi um movimento glocal por excelência em virtude de suas alianças. O movimento dos seringueiros e sua aliança com os povos indígenas transformavam-se, assim, num "paradigma do desenvolvimento sustentável com participação popular", um forte "movimento de resistência ecológica" (ALMEIDA, 2004, p. 33).

Após o assassinato de Chico Mendes em dezembro de 1988, a Aliança dos Povos da Floresta foi lançada oficialmente no dia 12 de maio de 1989, em São Paulo, pelos representantes da União das Nações Indígenas ${ }^{105}$ e do Conselho

${ }^{103}$ Nas áreas ameaçadas de desmatamento, os seringueiros e suas famílias, mulheres e crianças, abraçavam as árvores, tentando impedir a derrubada. Os primeiros empates ocorreram no município da Brasiléia com Wilson Pinheiro e tiveram continuidade com Chico Mendes. Nessas primeiras ações, eles conseguiram algumas vitórias, a maior delas aconteceu posteriormente, na medida em que o movimento foi ganhando fama internacional, com a aprovação das Reservas Extrativistas. Contudo, essa grande visibilidade não impediu a violência contra suas maiores lideranças. Ambos, Chico Mendes e Wilson Pinheiro, foram assassinados (ALMEIDA, 2004).

104 Após essas ações localizadas e diretas por meio dos empates, os seringueiros recorrem às instâncias internacionais (Organização das Nações Unidas), assessorados por antropólogos e por ativistas, para a defesa da Amazônia. Apenas após a causa dos povos da floresta ganhar os holofortes internacionais o governo brasileiro começou a "ouvir" as vozes daquele movimento.

${ }^{105}$ A União das Nações Indígenas (UNI) foi um fórum intertribal voltado para a articulação indígena nacional. Primeira instituição indígena brasileira que conseguiu, ainda com dificuldades internas e externas, estabelecer uma pauta de reivindicações, expressando um protagonismo indígena inédito na cena política no país. Fundada durante o Seminário de Estudos Indígenas de Mato Grosso do Sul realizado em Campo Grande, entre os dias 17 e 20 de abril de 1980, organizado pela Universidade Federal do Mato Grosso, com o apoio do governo do Estado e da FUNAI, contou com a presença de quinze etnias, principalmente de comunidades indígenas do Centro-Sul, intelectuais, antropólogos, universitários, militantes e simpatizantes da causa indígena. A UNI nasceu num contexto de grande conflito de terras, de corrupção e de desvios de recursos na FUNAI e de falta de assistência médica e escolas em terras indígenas. Ao mesmo tempo, havia conflitos internos que iam do predomínio de lideranças Terena à emergência de novas lideranças sem os vínculos com suas comunidades, e a falta de representatividade e de recursos para a articulação de um movimento nacional. Após a descentralização de sua organização, dividida por regiões, a UNI alcançou breve e relativa dinamicidade. Na época havia sido eleito Mario Juruna (PDT - Rio de Janeiro), o primeiro deputado federal indígena do país, que junto à UNI atuaram significativamente na luta pelo reconhecimento dos direitos das populações indígenas na Constituição de 1988. A 
Nacional dos Seringueiros ${ }^{106}$, constituindo um marco importante do indigenismo e do ambientalismo acreano, com destaque para a região do Alto Juruá (PIMENTA, 2007).

Nas palavras do antropólogo José Pimenta (2007, p. 639):

\begin{abstract}
A Aliança dos Povos da Floresta testemunha não apenas a capacidade de resistência das populações indígenas em face das políticas integracionistas e assimilacionistas do Estado, mas também exemplifica a criatividade e o dinamismo das recomposições identitárias contemporâneas. A Aliança não se encaixava nas visões classistas e quebrava o padrão de análise tradicional das relações de trabalho na Amazônia. Ela surgiu como resposta a lutas imediatas e localizadas, mas gerou movimentos mais abrangentes, combinando de maneira original localismo e universalismo (Almeida, 1994, pp. 521-37). Ao partir de uma situação de exploração comum a índios e seringueiros, seu principal objetivo era apresentar um bloco compacto e eficiente de reivindicações diante do Estado para garantir o controle de territórios considerados fundamentais para a afirmação da identidade e a (re)produção sociocultural dessas comunidades.
\end{abstract}

A existência desses povos, somada a suas formações socioculturais arraigadas neste território - a Floresta -, compôs as especificidades desse movimento tão reticular quanto à própria Floresta e a sua cartografia complexa de sentidos. Contudo, nos anos de 1990, essa articulação histórica foi aos poucos sendo desativada por divergências entre as lideranças indígenas e seringueiras.

Certamente por causa desse movimento os "Povos da Floresta" tornaram-se um potente emblema político ao longo da história do Acre, utilizado pelo rearranjo das forças sociais organizadas na década de 1980, como vimos, do movimento dos seringueiros e indígenas da Aliança dos Povos da Floresta aos sindicalistas e militantes do Partido dos Trabalhadores (PT). Este último conseguiu consolidar-se nos últimos vinte anos à frente do governo do Estado valendo-se dessa marca.

mobilização das lideranças indígenas em torno da UNI, em parceria com outras entidades indigenistas importantes, como o CIMI, a Comissão Pró-Índio, entre outras, foi fundamental para a garantia, na Nova Constituição, do reconhecimento da autonomia e da diversidade desses povos por parte do Estado Brasileiro (DEPARIS, 2007). O papel da UNI na criação da Aliança dos Povos da Floresta aconteceu nesse contexto pós-Constituição, num período em que a UNI iniciava sua fase de desarticulação nacional dado o crescimento das demandas regionais. Nesse momento, das suas unidades regionais restou atuante somente a UNI-Acre (União das Nações Indígenas do Acre, do Sul do Amazonas e Noroeste de Rondônia), fortemente articulada com outros movimentos da região acreana, como o dos seringueiros, conformando na criação da Aliança.

106 O Conselho foi criado em outubro de 1985 após o Primeiro Encontro Nacional dos Seringueiros, realizado em Brasília com a presença de suas principais lideranças, entre elas Chico Mendes. Posteriormente, transformou-se no atual Conselho Nacional das Populações Extrativistas da Amazônia, formado por lideranças agroextrativistas da região. 
Explicitamente na gestão do engenheiro florestal Jorge Viana (1999-2007) instituiuse o "Governo da Floresta", a seringueira e sua logomarca, vinculando em sua plataforma política esses povos enquanto práticas discursivas estratégicas de inclusão sociocultural, sustentabilidade e legitimação de poder. Desse modo, o imaginário e as imagens associadas às populações indígenas e aos seringueiros foram performatizados com frequência e à exaustão nos espaços ${ }^{107}$ e nas políticas públicas estaduais $^{108}$.

Tanto a "Floresta" quanto seus "Povos" compuseram (e compõem) o repertório dessa "comunidade política imaginada", nos termos de Benedict Anderson, ao ponto do aparecimento da expressão "florestania". Cunhado pelo cronista acreano Antonio Alves na década de 1980, o termo sublinha a relevância territorial e ambiental da região na composição do imaginário, da participação e do exercício da cidadania, marca de uma distinção política e regional acreana.

Diferente de um discurso de governo para essas comunidades, a Rede Povos da Floresta surgiu, então, para retomar o sentido genuíno do movimento que originou a Aliança. Portanto, buscando atualizar essa mobilização histórica, a Rede nasceu da rearticulação dos povos indígenas (principalmente dos Ashaninka, Kontanawa, Kaxinawa), dos ribeirinhos, das populações extrativistas e quilombolas e de organizações não governamentais parceiras, como a Associação de Cultura e Meio Ambiente (Rio de Janeiro) e o Núcleo de Cultura Indígena (Minas Gerais). Eles se uniram com o objetivo de consolidar a rede dessas comunidades tradicionais, conectadas por meio das tecnologias digitais de comunicação (internet e sistemas de georreferenciamento com GPS) para a preservação do ambiente, incluindo seus aspectos naturais, culturais e simbólicos.

Conectadas pela internet via satélite, essas comunidades articulam projetos, trocam informações com seus apoiadores, acionam os órgãos públicos quando da ocorrência de invasões de suas terras, além de realizarem o registro audiovisual de

\footnotetext{
107 Na capital, Rio Branco, a "Praça dos Povos da Floresta" e a "Biblioteca da Floresta" são exemplos da reinscrição política do termo no espaço urbano.

108 Do governo estadual atual, resta utilizando tal emblema a política pública de inclusão digital Floresta Digital. Essa ação oferece acesso à internet em banda larga sem fio e em telecentros públicos baseada numa rede de dados provida pelo Governo do Acre, destinando a implementação de ações públicas de inclusão social, digital e de modernização da gestão pública. Embora a RPF tenha obtido apoio do poder público para a implantação da conexão entre as comunidades participantes, a parceria de mais destaque ocorreu com o Governo Federal (2009-2010), e não com o Estadual. Mais informações, consultar o site: http://www.florestadigital.acre.gov.br
} 
suas memórias e narrativas, iniciativa que associa seus territórios e culturas à conectividade e às linguagens midiáticas digitais.

\subsection{NOS CIRCUITOS DA REDE}

Conheci pela primeira vez a Rede Povos da Floresta (RPF) ao mapear os sites indígenas brasileiros durante a realização da pesquisa de mestrado sobre a presença nativa no ciberespaço. Na época, em meados de 2004, após uma busca preliminar no Google vi a divulgação da Rede em uma matéria hospedada no site do Comitê para a Democratização da Informática (CDI) ${ }^{109}$. Porém, por não se tratar de uma experiência exclusivamente indígena, não a utilizei no corpus da investigação. Após finalizar a dissertação (2007) e versando no doutorado para o estudo de experiências reticulares de culturas locais, voltei ao caso dos Povos da Floresta como oportunidade de tecer novas reflexões sobre esse processo de digitalização.

Desde 2009 venho pesquisando no site da RPF, cujo endereço é http://www.redepovosdafloresta.org.br ${ }^{110}$. Inicialmente primei por uma imersão em sua arquitetura informativa, buscando interagir, observar e descrever a organização da informação e de suas interfaces, e paralelamente analisar seus discursos, inferindo sobre o processo de digitalização em curso. Percebi ao longo das imersões que essa arquitetura informativa digital (site) tem por objetivo informar aos internautas e aos parceiros da Rede as atividades decorrentes das ações reticulares de seus atores-redes. Identifiquei essa arquitetura informativa digital como "metarreticular" por seus hipertextos ${ }^{111}$ conterem, sobretudo em sua significação, a

\footnotetext{
109 Criada em 1995, o Comitê para a Democratização da Informática (CDI) é uma entidade sem fins lucrativos, voltada para a utilização da tecnologia da informação como instrumento para a construção e para o exercício da cidadania. O CDI foi um dos apoiadores iniciais da Rede Povos da Floresta em parceria com a empresa de telecomunicações StarOne, entre outras.

110 A pesquisa em seus posts ocorreu entre 2009 e 2011. Cheguei a apresentar um paper com os resultados parciais no IV Simpósio Nacional de Pesquisadores em Cibercultura. Rio de Janeiro, 18 a 21 de novembro, na mesa do eixo temático: "4. Biopolítica, Vigilância e Ciberativismo", intitulado: "Mídias nativas digitais e netativismo ecossistêmico - o caso da Rede Povos da Floresta". Disponível em: moodle.stoa.usp.br/mod/resource/view.php?id=31227.

111 Refiro aos hipertextos as tramas movidas pela simultaneidade de códigos: ícones, grafismos, linguagens, reconfiguráveis por meio da interação que pressupõe a atuação e o enriquecimento da leitura na multiplicação da produção de sentidos. O hipertexto - composto de blocos de textos, ou nós, conectados por links - forma uma coleção de informações multinodais disposta em rede para navegação rápida e intuitiva, texto móvel, caleidoscópico (LÉVY, 1996). Para Giovanna Mascheroni
} 
narrativa da apresentação da Rede (de seus atores-redes) e de seu desenvolvimento.

Durante a preparação deste capítulo percebi que a descrição de imersões nas arquiteturas informativas digitais é uma tarefa ingrata. "Narrar" tal percurso interativo e perceptivo pode resultar numa leitura exaustiva, complexa e até confusa para o leitor. Ao mesmo tempo, minha interação, ao ser textualizada, parecia estar aprisionada na cadência linear do texto escrito, destituindo a sua complexidade no sentido de Morin. Por não ter muitas escolhas, afinal, a tese é uma produção sobretudo escrita, optei por descrever a composição primordial dessa arquitetura informativa digital, recorrendo em minhas observações às reflexões sobre esse processo recursivo, dialógico e reticular.

e Francesca Pasquali (2006), suas características abrangem: associatividade, interatividade e virtualidade. A primeira, porque as redes de conexão se ligam aos módulos de informações que o compõem. A segunda, porque depende da ação/interação do usuário. A terceira, porque os nós e os links são potenciais percursos de navegação e conexão e se tornam "atuais" com a ação do usuário. Tem-se, portanto, nos hipertextos, a virtualização do próprio texto. 


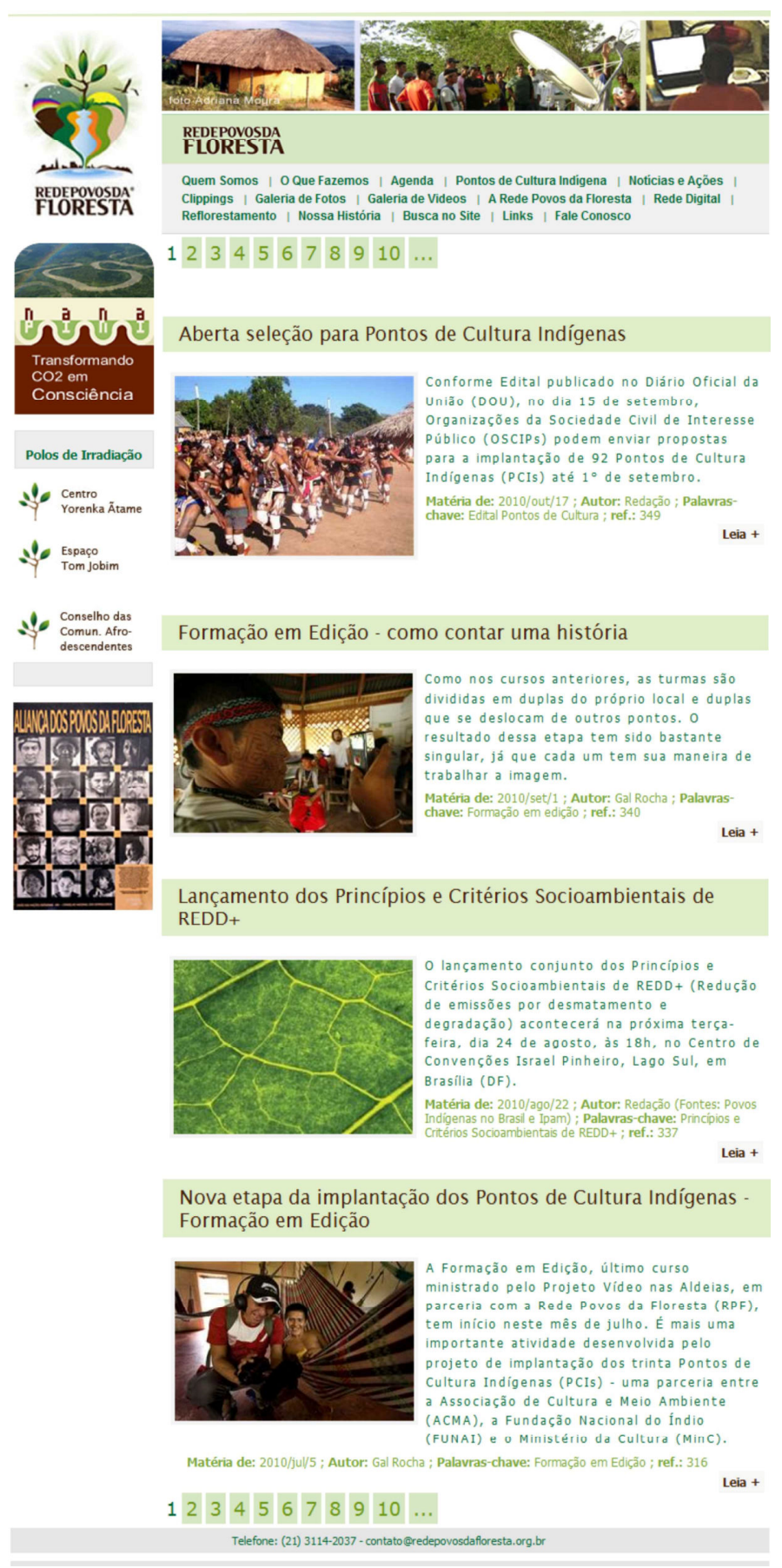

Figura 1 - Captura do site da Rede Povos da Floresta

Com arquitetura informativa simples, com poucos recursos interativos ${ }^{112}$, naveguei em suas informações hipertextuais. No layout do site prevalece a cor verde clara. No topo, as imagens de uma casa tradicional, pessoas ao redor de uma antena de captação de sinal via satélite e uma pessoa em frente a um laptop, revelam os sentidos imagéticos da Rede. À esquerda, sua logomarca traduz a

\footnotetext{
${ }^{112}$ Refiro-me aos recursos de comunicação sincrônica, em tempo real, com os membros da rede. Os recursos interativos são geralmente espaços para conversação simultânea (bate-papo),
} comentários, etc. 
conectividade da Floresta com a cidade. Um desenho embrenhado de referências: a cidade conectada pela água que escorre do rio, o "mundo da floresta" em formato de coração, no alto uma nuvem carregada de estrelas, arco-íris, sol, vegetação, rio, pássaros voando. Não há elementos tecnológicos nem humanos, só esses ecossistemas integrados por seus elementos essenciais.

No menu horizontal da barra de informações encontram-se ordenados da esquerda para a direita, os seguintes links: "Quem somos", "O que fazemos", "Agenda”, "Pontos de Cultura Indígena”, "Notícias e Ações”, “Clippings”, "Galeria de fotos", "Galeria de Vídeos", "A Rede Povos da Floresta", "Rede Digital", "Reflorestamento", "Nossa história", "Busca no site", "Links" e "Fale conosco", os quais descrevo adiante em sessões específicas. Cada um dos links é composto por post (matéria/publicação) e, por sua vez, cada um deles é "tagueado" (identificados por tags, etiquetas ou palavras-chave por assunto) com as seguintes informações: matéria de: ano/mês/dia, autor, palavras-chave. Nem toda informação no site obedece a essa forma de identificação, mas percebo a tentativa de organização e transparência do conteúdo publicado.

A espacialidade comunicativa da arquitetura informativa digital se estabelece no decorrer dos posts pela narrativa da dinâmica da construção da Rede: as rodas de conversas ${ }^{113}$, a instalação da infraestrutura, as viagens, as oficinas de formação para as comunidades envolvidas, os encontros, os apoios, etc. Esses acontecimentos são relatados por Gal Rocha e Stefania Fernandes, que assinam os posts $^{114}$. São divulgadas matérias jornalísticas publicadas pela mídia impressa veiculadas no site na secção "Clipping". No geral, a narrativa tem um cunho jornalístico de divulgação das ações da Rede, respondendo a um padrão de informar a um público mais geral, com linguagem acessível, os andamentos dessa experiência.

${ }^{113}$ As rodas de conversa são encontros entre diversos atores sentados em círculo, dialogando, conversando, trocando informações e estabelecendo, assim, um método horizontal de participação. Nas palavras de Ailton Krenak: "numa roda de conversa, ninguém tem patente, somos todos soldados" (Vídeo Primeira Roda de Conversa RPF, 2009). Nos últimos anos vem sendo bastante difundida no âmbito das atividades governamentais que envolvem diretamente comunidades tradicionais e outros coletivos.

${ }^{114}$ A maioria dos posts é assinada por Gal Rocha, jornalista contratada pela RPF de 2006 a 2010. Em entrevista realizada com ela, via Facebook, em janeiro de 2012, afirma que havia uma equipe responsável pela comunicação do site, coordenada por Stefania Fernandes, que lia todo o material antes da publicação, com a participação de Alice Fortes, fotógrafa, e Ricardo Conte, desenvolvedor do site. Todos são do Rio de Janeiro. 
Prosseguindo com a descrição do layout do site, logo abaixo, no menu da barra vertical à esquerda, apresenta-se o ícone do Projeto Nanapini (que na língua aruwak significa "entidade espiritual de cura da floresta") de venda de crédito de carbono. Ao clicarmos sobre a imagem somos automaticamente reportados ao site do projeto, que encontra-se fora do ar (por motivos desconhecidos). Descendo, sempre à esquerda, são anunciados os três "polos de irradiação" da Rede: o Centro Yorenka Ãtame (situado no município de Marechal Thaumaturgo - Acre), o Espaço Tom Jobim (Jardim Botânico, Rio de Janeiro) e o Conselho das Comunidades Afrodescendentes (Macapá-Amapá). Ambos os espaços-lugares indicadores da reterritorialização dos pontos de agregação e irradiação da Rede, os quais descrevo a seguir, baseando-me nas informações do próprio site e com apoio da pesquisa bibliográfica.

O Centro Yorenka Ãtame (na língua Ashaninka significa Saberes da Floresta), inaugurado em 2007, foi idealizado pela aldeia Ashaninka do Rio Amônia - Apiwtxa (Terra Indígena do Kampa). Situado ao lado direito do rio Juruá, na frente do Município de Marechal Thamaturgo (AC), o Yorenka Ãtame foi criado como um espaço de educação, formação, intercâmbio de práticas de manejo sustentável dos recursos da região, integrando com o uso dos sistemas agroflorestais as populações indígenas e não indígenas na recuperação de áreas degradadas. Considero a expressão máxima de um projeto ousado e pioneiro de desenvolvimento sustentável promovido por uma comunidade indígena brasileira e, portanto, inserto em uma estratégia muito peculiar de política interétnica realizada pelos Ashaninka da aldeia Apiwtxa. Ao somar-se à capacidade de associação e de conectividade de seus membros, o Centro forma um importante "nó" da RPF.

Constituindo-se em um polo urbano da RPF, o Espaço Tom Jobim - Cultura e Meio Ambiente está instalado nas antigas construções do Instituto de Pesquisa Jardim Botânico do Rio de Janeiro. Voltado para a promoção da união da cultura e do meio ambiente, e por reconhecer esse elo no trabalho do músico Antonio Carlos Jobim, esse Espaço foi batizado em homenagem ao artista. Além de abrigar o acervo virtual de Tom Jobim, tem uma galeria de exposição e um teatro, realizando eventos com a finalidade de promover a cultura e a arte, especialmente correlacionados com a defesa, a preservação e a conservação do meio ambiente e a promoção do desenvolvimento sustentável (RPF, 2008).

A proposta do Espaço é: 
retratar a riqueza e singularidade da cultura brasileira e seu meio ambiente tendo como base os hábitos e valores das comunidades tradicionais integradas na sociedade contemporânea através da música, das artes cênicas, da dança, das artes plásticas, do cinema e principalmente através das suas relações culturais com o território onde habitam. (RPF, 2008) ${ }^{115}$

Em torno dessa concepção de valorização das comunidades tradicionais associada às manifestações artísticas contemporâneas, uma rede importante de apoio estabeleceu-se com diversos artistas, atores globais, músicos, militantes ambientalistas e empresários do Rio de Janeiro, tornando esse Espaço um importante ponto de encontro da RPF na cidade carioca. Inaugurado em 2003, foi criado em conjunto com a Associação de Cultura e Meio Ambiente (ACMA), responsável pela manutenção do Espaço, por iniciativa do músico e arquiteto Paulo Jobim, primeiro filho de Jobim, o ambientalista e empresário João Augusto Fortes, a figurinista, cenógrafa e produtora cultural Biza Vianna, o líder indígena Aílton Krenak, a paisagista e escritora Cecília Beatriz da Veiga Soares e a gestora de projetos socioambientais Cristina Reis (RPF, 2008) ${ }^{116}$.

O Conselho das Comunidades Afrodescendentes (CCADA), também fundado em 2003, objetiva representar os interesses dessas comunidades no estado do Amapá, incluindo os afrodescendentes na rede. Após a união de 24 comunidades rurais contra a empresa ICOMI de minério de ferro, que pretendia enterrar rejeitos tóxicos em terras quilombolas, o CCADA foi criado para articular essas comunidades, fortalecer as associações comunitárias, apoiar a titulação de terras quilombolas, incubar e implantar projetos de desenvolvimento sustentável local (RPF, 2003) ${ }^{117}$. Para o desenvolvimento de suas atividades, o Conselho recebeu o apoio da Fundação AVINA, fundação suíça pelo Meio Ambiente e da empresa paulistana APEL (Pesquisa e Desenvolvimento de Projeto). Contudo, mesmo havendo a referência no site como polo de irradiação da RPF, encontrei poucas atividades relacionadas ao Conselho que atualmente é parceiro da Rede

\footnotetext{
115 Disponível em: http://redepovosdafloresta.org.br/exibePagina.aspx?pag=5. Acesso em: 23 out. 2011.

116 Disponível em: http://www.redepovosdafloresta.org.br/exibePagina.aspx?pag=5. Acesso em: 24 out. 2011.

117 Disponível em: http://www.redepovosdafloresta.org.br/exibePagina.aspx?pag=7. Acesso em: 25 out. 2011.
} 
Mocambos $^{118}$, uma rede de negras e negros, comunidades quilombolas rurais e urbanas de âmbito nacional conectadas através das TIC's.

Percebi então que, embora o Conselho figure a presença das populações quilombolas na RPF, esta menção não se traduz de fato numa intensa atuação destas nessa ação reticular. Veremos posteriormente que o prevalecimento de povos indígenas, caboclos, seringueiros (sobretudo de origem nordestina), ribeirinhos, é fruto do enraizamento desses povos na Floresta, algo típico do contexto acreano, principalmente do Alto Juruá. É importante considerar que não há remanescentes de quilombos na região, e a presença de populações afrodescendentes não era concentrada numericamente numa localidade específica. Isso ocorreu em grande parte devido à dispersão anterior dessas populações, antes da sua chegada como trabalhadores nas colocações ${ }^{119}$ dos seringais. Um exemplo notório é o de Raimundo Irineu Serra, Mestre Irineu, nascido em São Vicente Ferrer (Maranhão), filho do ex-escravo Sancho Martino Serra e de Joana Assunção Serra, que migrou para o Acre no fim do primeiro ciclo da borracha (1879-1912), trabalhou nos seringais e fundou, após o contato com os povos indígenas, a doutrina do Santo Daime.

Ao perscrutar as informações dispostas na barra vertical do site, passo para o menu superior, descrevendo os links anunciados, agrupando-os por sua proximidade temática.

\subsection{1 "Quem somos"}

Da seç̧ão "Quem somos" sigo minha incursão pelas conexões e associações da RPF. Publicado em 12 de abril de 2003, data de criação do site, este post denota a performatização de "quem é" a Rede, "quem são" aqueles que a constituem, moldada pela ideia de uma aliança desses povos que extrapola seus habitantes. É emblemática a foto de Ailton Krenak (à esquerda), Benki Pianko (ao centro) e João

\footnotetext{
${ }_{118}^{118}$ Para mais informações, ver site da Rede Mocambos, disponível em: http://www.mocambos.org/.

119 Colocação é um termo dado à área do seringal onde a borracha era produzida. Ao mesmo tempo, situa o espaço vivido e o do trabalho na mata, incluindo a casa dos seringueiros e as entradas de seringa, os caminhos realizados para a extração do látex. As colocações são a base do conceito de Reserva Extrativista proposto pelo movimento dos seringueiros dos anos de 1980 (ALMEIDA, 1990).
} 
Augusto Fortes (à direta) abraçados com sorrisos entusiasmados, representando os grupos e as instituições envolvidas, fundamentais para a implantação e a constituição dessa experiência reticular.

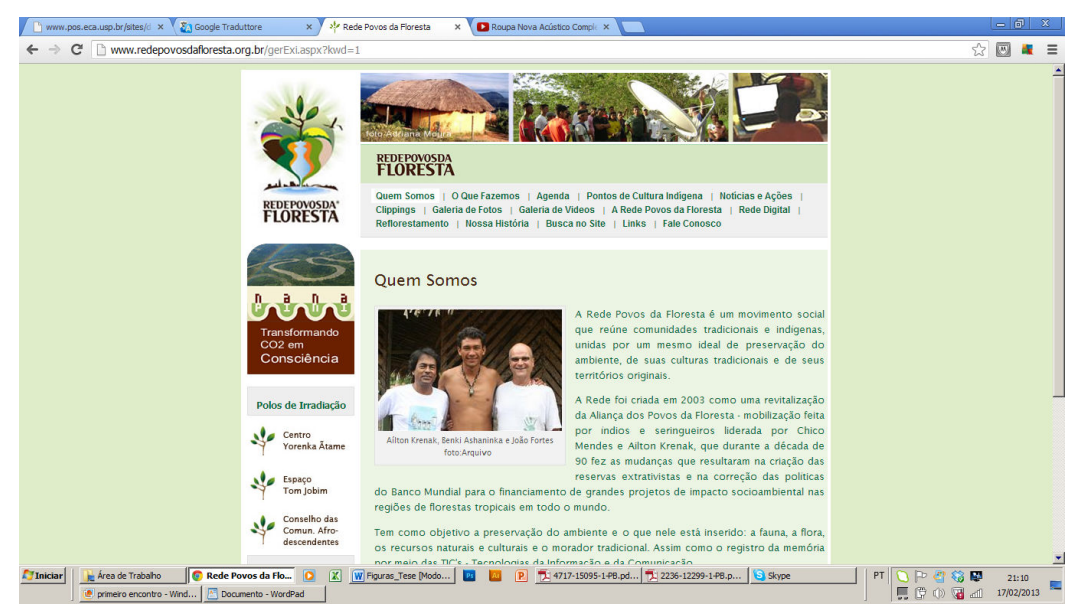

Figura 2 - Captura de tela do site Rede Povos da Floresta "Quem somos"

Encontro-me diante de uma importante associação de tecno-atores ou atoresredes (composta não somente de humanos, mas também de redes informativas, computadores, telefones, etc.) mediadores e tradutores culturais, conectores de imaginários ${ }^{120}$, de planos sensíveis, de organizações, que, articulados aos seus ambientes envolventes, à flora e à fauna, delineiam um sugestivo ecossistema informativo. Representam uma sinergia reticular que ultrapassa a arquitetura informativa digital do site, essa face visível desterritorializada estendida semioticamente na paisagem midiática digital das redes.

A foto de Ailton Krenak, Benki Pianko e João Fortes juntos reforça, simbolicamente, a aliança entre os povos representados pela própria imagem deles. Eles são mediadores culturais por excelência, espelhando a forte influência que cada um tem na Rede, arraigada pela fascicularidade de suas histórias de vida e de seus contextos.

Ailton $\mathrm{Krenak}^{121}$ tem uma longa trajetória de militância no movimento indígena brasileiro. Oriundo do grupo Krenak ${ }^{122}$, nascido em 1954, no Vale do rio Doce,

\footnotetext{
${ }^{120}$ Veremos, adiante, que Krenak, Pianko e Fortes configuram, por excelência, pessoas que possuem contextos e estilos de vida distintos. São "figuras mercurianas", mediadores comunicativos de diferentes planos, como os xamãs, embora entre eles só Benki Pianko de fato o seja.

${ }^{121}$ Consultar o blog de Ailton Krenak (ailtonkrenak.blogspot.br).

122 Os Krenak pertencem ao grupo linguístico Macro-Jê, falando a língua denominada Borun. São os últimos Botocudos do Leste, "nome atribuído pelos portugueses no final do século XVIII aos
} 
Minas Gerais, migrou com a sua família aos 17 anos para o Paraná, onde alfabetizou-se, tornando-se produtor gráfico e jornalista. Passa a atuar no efervescente movimento indígena na década de 1980, que resultou na fundação da União das Nações Indígenas (UNI). Participou ativamente da Assembleia Constituinte, em 1987, realizando o gesto marcante, no plenário da Câmara, de pintar o rosto com pasta de jenipapo enquanto discursava em sinal de luto pelo retrocesso na tramitação dos direitos indígenas.

Desde 1985 era o apresentador do Programa de Índio ${ }^{123}$ junto com Álvaro Tukano $^{124}$ e Biraci Yawanawá ${ }^{125}$, transmitido pela Rádio USP FM, 93,7 MHz, expressando a voz e o pensamento dos povos indígenas situados no Brasil. Idealizado e realizado pelo Núcleo de Cultura Indígena $(\mathrm{NCl})$, braço oficial da União das Nações Indígenas, esse programa abriu um espaço importante de comunicação entre as aldeias indígenas e o público urbano, de forma direta e original (PEREIRA, 2012). Tal iniciativa foi possível pelo apoio da Escola de Comunicações e Artes (USP) e pela colaboração de jovens jornalistas, como Ângela Papiani, produtora do programa nessa época.

Em 1989, após o assassinato de Chico Mendes, Krenak juntou-se aos seringueiros e aos povos indígenas da região do Acre para a construção da Aliança

grupos que usavam botoques auriculares e labiais. São conhecidos também por Aimorés, nominação dada pelos Tupí, e por Grén ou Krén, sua auto-denominação. O nome Krenák é o do líder do grupo que comandou a cisão dos Gutkrák do rio Pancas, no Espírito Santo, no início do século XX. Localizaram-se, naquele momento, na margem esquerda do rio Doce, em Minas Gerais, entre as cidades de Resplendor e Conselheiro Pena, onde estão até hoje, numa reserva de quatro mil hectares criada pelo SPI, que ali concentrou, no fim da década de 20, outros grupos Botocudos do rio Doce: os Pojixá, Nakre-ehé, Miñajirum, Jiporók e Gutkrák, sendo este o grupo do qual os Krenák haviam se separado" (ISA, 2012). Restam, atualmente, 350 indivíduos (FUNASA, 2010).

123 Com duração de trinta minutos, apresentado semanalmente por ele, Álvaro Tukano e outras pessoas indígenas de várias etnias, o Programa de Índio trouxe aos ouvintes a participação de lideranças indígenas, apoiadores não indígenas da causa, música das aldeias e informações sobre a diversidade indígena, além de apresentarem cartas e fitas gravadas com denúncias, informações e músicas enviadas ao programa pelas populações indígenas. Foram ao todo 220 programas gravados em quatro anos, digitalizados recentemente e disponibilizados no site http://www.programadeindio.org/. Vale a pena ouvi-los, pois é um pedaço da história do movimento indígena em uma das suas fases mais efervescentes, uma ação comunicativa singular para a época.

124 Álvaro Tukano, nascido em 1953, é uma liderança histórica do movimento indígena brasileiro e membro da Federação das Organizações Indígenas do Rio Negro, no Amazonas (FOIRN), sendo descendente da etnia Tukano, que vivem às margens do Rio Uaupés e de seus afluentes. São 6.241 (Dsei/Foirn, 2005) indígenas e integram atualmente 17 etnias, muitas das quais vivem também na Colômbia, na mesma bacia fluvial e na bacia do Rio Apapóris (ISA, 2012).

125 Biraci Brasil Yawanawá foi o coordenador da UNI-Norte na época. Atualmente é dos organizadores do Festival Yawa, uma grande festa realizada pelo povo Yawanawá com rituais, música e dança. Os Yawanawá estão localizados no Acre, Bolívia, Peru, com 541 indivíduos (FUNASA, 2010). 
dos Povos da Floresta, cuja proposta era a criação das reservas extrativistas em busca de proteger a floresta e as populações que nela/dela vivem. Atualmente, mora na cidade de Nova Lima, Minas Gerais, e se empenha nas atividades da coordenação da Rede Povos da Floresta e do Núcleo de Cultura Indígena.

Benki Pianko ${ }^{126}$, Ashaninka da aldeia Apiwtxa do Rio Amônia, Alto Juruá (Acre), nasceu em 1974. Filho do casamento interétnico entre Antonio Pianko (kuraca da aldeia, equivalente ao cacique) e Dona Piti (filha de seringueiros), sua família exerce forte influência na política interétnica Ashaninka (PIMENTA, 2002, 2007; LESSIN, 2011), formando o núcleo estratégico de toda a política Ashaninka na região. Seu irmão mais velho, Francisco, é assessor da FUNAl em Brasília e já foi secretário indígena do governo do Estado do Acre; Moisés, xamã ${ }^{127}$ e presidente da Associação Ashaninka Apitwa, divide com Benki a responsabilidade de representar a aldeia Ashaninka do Amônia externamente. Moisés destaca-se também por suas pinturas, expostas no Rio de Janeiro (2009), e ilustrou a Enciclopédia da Floresta (CUNHA e ALMEIDA, 2002). Ambos, Benki e Moisés, são os articuladores diretos com outros tecno-atores da Rede Povos da Floresta e são sempre mencionados nos posts que dizem a respeito aos Ashaninka. Isaac foi secretário de Meio Ambiente e Turismo de Marechal (2009-2012), é professor e tesoureiro da Associação Apiwtxa. Bebito, o filho mais novo, é documentarista e cineasta; Dora, agente de saúde e cordenadora da cooperativa; e Alexandrina, a mais nova, assessora os irmãos na gestão da cooperativa.

Benki é agente agroflorestal, compositor, músico e xamã. Foi secretário de Meio Ambiente e Turismo de Marechal Thaumaturgo (2005-2007). Recebeu diversos prêmios pelo seu trabalho na área do desenvolvimento sustentável, entre os quais o Prêmio Nacional de Direitos Humanos (2004) e o mais recente Premio-e (2012). É curioso e desde pequeno teve contato com o mundo artístico nacional. Milton

${ }^{126}$ A grafia do nome de Benki Pianko varia nos textos e matérias relacionados a ele ou a sua família. Foram registrados, além de "Benke" e "Benki Pianko", também a variação na escrita do seu sobrenome Piãnko, Piyãko, Pinhanta, Ashaninka. Optei pela grafia "Benki Pianko" após receber email assinado dessa forma por ele.

127 O termo "xamã" origina-se dos povos siberianos Tungusi. Corresponde àquele que tem uma relação privilegiada ao transitar entre os humanos e os espíritos e realiza ritos de cura. No caso dos Ashaninka, os xamãs (sheripiari) são aqueles que, ao ingerirem a ayahuasca (kamarãpi), adquirem o conhecimento dado por Pawa (Deus criador Ashaninka). Segundo a cosmologia desse povo, a bebida é um legado de Pawa para os Ashaninka adquirirem conhecimento e para que possam aprender a viver na Terra. O conhecimento xamânico deriva de uma formação perpétua, de aprendizado e consumo regular da bebida. "É através do kamarãpi que o sheripiari realiza suas viagens nos outros mundos e adquire a sabedoria para curar os males e as doenças que afetam a comunidade" (PIMENTA, 2005). 
Nascimento, em viagem dedicada à produção de seu álbum Txai ${ }^{128}$ (1991), conheceu Benki ainda criança e Ihe dedicou a canção Benke. Com seu carisma, construiu uma rede de apoiadores, entre empresários e artistas, com a qual conseguiu arrecadar verba suficiente para a construção do Centro Yorenka Ãtame, também chamado Escola Saberes da Floresta, do qual é coordenador.

João Augusto Fortes, ambientalista e empresário da construção civil, é um articulador fundamental no lado urbano da Rede. Trouxe parceiros importantes da iniciativa privada, entre eles Luís Paulo Montenegro, do IBOPE ${ }^{129}$, João Alfredo Viegas, da Concremat, e Paulo Jobim, além de ter ajudado a elaborar o projeto de venda de crédito de carbono - Nanapini. Seu envolvimento com a Amazônia começa no final dos anos 1980, quando participou de várias passeatas em defesa da Floresta Amazônica no Rio de Janeiro, conhecendo pessoalmente a Chico Mendes. Era o momento da explosão da causa "ecológica" no Brasil, com a internacionalização dos problemas enfrentados pelas populações da região amazônica, as queimadas e a devastação da floresta em decorrência direta de uma política governamental de incentivo à colonização da região pela ampliação das áreas de pasto.

Com o assassinato de Chico Mendes, João Fortes decidiu embrenhar-se na região, a princípio motivado por um sentimento romântico de luta para a "salvação" da Amazônia e, em seguida, envolvido com um empreendimento econômico e social. O discurso e o carisma do líder seringueiro contagiaram uma geração de jovens no Rio de Janeiro, cidade que se tornava palco mundial dos debates na Conferência das Nações Unidas sobre o Meio Ambiente e o Desenvolvimento, mais conhecida como Eco- $92^{130}$. Ao mesmo tempo, a ecologia começava a ser vista por muitos também como "um bom negócio", apontando para novas oportunidades em ramos emergentes (MCCORMICK,1992). Foi nessa época que, junto a Bia

${ }^{128}$ A expressão "Txai" de origem Kaxinawá, significa "companheiro", "irmão", "camarada", "metade de mim". A expressão é de uso corrente no Acre, tanto por indígenas quanto por seringueiros e ribeirinhos.

${ }^{129}$ Engenheiro de produção pela Universidade Federal do Rio de Janeiro, vice-presidente do Grupo IBOPE, membro do Conselho de Diretoria do Worldwide Wildlife Fund for Nature (WWF) no Brasil e do Conselho de Governança do Grupo de Institutos, Fundações e Empresas (GIFE). Segundo Benki Piãnko, o apoio de Luis Paulo Montenegro foi fundamental para que a Apiwtxa conseguisse arrecadar doações para a compra do terreno sede do Yorenka Ãtame. Em 2011, é lançado em sua gestão o IBOPE Ambiental, unidade de negócios na área do meio ambiente com serviços voltados para o desenvolvimento sustentável e para o controle do aquecimento global.

130 Para Nelson Simões, diretor geral da Rede Nacional de Ensino e Pesquisa (RNP), a primeira rede no Brasil ocorreu, de fato, na Eco-92, com a articulação das organizações não governamentais para prover serviços de correio eletrônico (SAVAZONI e COHN, 2009, p. 112). 
Saldanha, dona de uma boutique em Ipanema, investiu na produção e na comercialização de couro vegetal, empreendimento pioneiro no país na linha ecobusiness. Envolvendo em sua cadeia produtiva seringueiros e comunidades tradicionais da região, tal aventura virou o livro Amazônia, $20^{\circ}$ andar (Editora Record, 2009) nas mãos do jornalista Guilherme Fiúza. É Diretor do Espaço Tom Jobim no Rio de Janeiro e participa desde o início da criação da Rede Povos da Floresta.

Por sua vez, o processo de digitalização constitutivo da RPF não decorreu do empenho isolado dessas três figuras emblemáticas, mas sim de uma série de contatos e associações que envolvem os contextos locais e as diversas instituições comprometidas durante a sua constituição. A conexão Amazônia/Acre-Rio de Janeiro ocorreu na medida em que esses tecno-atores/atores-redes foram se associando em prol desse projeto de conexão das comunidades tradicionais ao longo desses quase dez anos, por meio de ações e eventos promovidos pela RPF.

\subsection{2 "O que fazemos" e "A Rede Povos da Floresta"}

Nessas duas seções, a Rede Povos da Floresta apresenta, em linhas gerais, as atividades promovidas, objetivando o investimento na infraestrutura comunicativa e informação para a preservação do meio ambiente, baseada numa percepção de desenvolvimento sustentável local e incentivando, assim, o reflorestamento e a valorização das comunidades tradicionais habitantes dessas localidades com o registro audiovisual da memória desses povos.

Portanto, o objetivo geral da Rede é "consolidar uma rede de comunidades tradicionais conectadas com o ideal de proteção de seus territórios e de sua cultura" (RPF, 2008), procurando, dessa forma, alcançar os seguintes objetivos específicos:

Fortalecer a gestão ambiental de áreas protegidas e seus entornos ao articular um novo papel para as comunidades tradicionais, com destaque ao monitoramento, vigilância e educação ambiental, de forma articulada com as políticas culturais, ambientais e com as agendas de promoção da sustentabilidade.

- Fortalecer o pleno gerenciamento da identidade cultural das comunidades beneficiadas; 
- Prestar o Serviço Ambiental do Desmatamento Evitado;

- Recuperar a diversidade bio-cultural local;

- Preservar os sistemas hidrológicos, minimizando o excesso das cheias e o alongamento das secas nos rios e igarapés;

- Desenvolver a troca de experiências tradicionais e oferecer esses conhecimentos para outras comunidades, principalmente de não indios;

- Oferecer para o mercado produtos certificados;

- Recuperação de áreas desmatadas por meio do serviço de créditos de carbono. (RPF, 2008)

Além de investir na infraestrutura de comunicação e informação, inclusão digital e intercâmbio entre os diversos povos tradicionais, a RPF promove também a infraestrutura "em recursos como georreferenciamento, radiofonia e acesso à Internet, que proporcionam condições favoráveis para a defesa do território e agilidade para a realização de denúncias contra práticas exploratórias ilegais ou abusivas" (RPF, 2003) ${ }^{131}$.

Ao longo dos quase dez anos da Rede, aquilo que eles fizeram e fazem assumiu formas imprevisíveis. Cada comunidade conectada fez da potencialidade da conexão, do registro de suas memórias e do monitoriamento de seu território a emanação de novos elos, de novas redes rizomaticamente (DELEUZE e GUATTARI, 1995).

Veremos, adiante, na "cronologia do desenvolvimento" da RPF que, ao propocionar a infraestrutura de TIC's, a inclusão digital e o intercâmbio entre as comunidades conectadas, ela vislumbrou uma nova relação com os objetos técnicos (tecnologias de comunicação e informação) e com a própria natureza, a Floresta.

Esses objetos técnicos também possuem o potencial de vincular ainda mais essas pessoas à própria natureza. Se para aquelas que estão na Floresta reforçariam sua governança, para os que não vivem nela promoveriam um reencontro com sua biodiversidade. Ao pensar especificamente nessa relação entre objetos técnicos e natureza, Gilbert Simondon (1989, p. 245) revê essa clássica oposição, segundo a individuação ocasionada pelos objetos técnicos:

O objeto técnico, pensado e construído pelo homem, não se limita apenas a criar uma mediação homem entre o homem e a natureza; ele é um misto estável do humano e do natural; ele confere a seu conteúdo humano uma estrutura semelhante à dos objetos naturais e

131 Disponível em: http://www.redepovosdafloresta.org.br/gerExi.aspx?kwd=2. Acesso em: 11 nov. 2012. 
permite a inserção no mundo das causas e dos efeitos naturais dessa realidade humana [...]. A atividade técnica vincula o homem à natureza [...].

Nessa 'natureza' dos objetos técnicos o próprio ser técnico é compreendido como informação: "O ser técnico só pode ser definido em termos de informação e de transformação das diferentes espécies de energia ou de informação, isto é, de um lado como veículo de uma ação que vai do homem ao universo, e de outro como veículo de uma informação que vai do universo ao homem" (SIMONDON, 1989, p. 196-197). Poderíamos substituir, nessa citação de Simondon, a palavra "universo" por "Floresta" para efetivarmos a interdependência entre ambos. Conforme o sociólogo Laymert dos Santos (1998, p. 44), ao repensar essa relação não opositiva feita por Simondon entre natureza e tecnologia, ele enfatiza que precisamos avaliar a "necessidade de salvar a bio-sociodiversidade com a necessidade de salvar, também, a tecnologia". Essa ideia de "salvação" do autor é um empreendimento de "redescoberta" do Brasil, reatando o contato com a natureza e com os povos indígenas aqui existentes.

\subsection{3 "Nossa história"}

Neste link, doze posts publicados em momentos diferentes da Rede evidenciam a história do povo Ashaninka do rio Amônia, do projeto da RPF, a importância das TIC's para a preservação do meio ambiente e, portanto, da Floresta e de seus bens simbólicos, além de ser divulgada a história dos trabalhos do Centro Yorenka Ãtame. Temos, nesta secção, as pistas sobre a autopercepção ou autoimagem da RPF, corroborada com os dispositivos técnicos de conexão.

Ao mesmo tempo em que reforça a valorização das identidades dessas comunidades locais, a Rede compreende essa ação aberta para o mundo, onde a comunicação permitirá a esses grupos a tomada de consciência de direitos e o reestabelecimento do contato com eles mesmos. Uma questão de sobrevivência cultural, possível com o diálogo com o mundo por meio das tecnologias de informação e comunicação: 
As nações indígenas e os povos tradicionais estão mais conscientes de sua identidade e da necessidade de abrir novos canais de comunicação com outros povos, rompendo preconceitos e criando alianças, sobretudo com as futuras gerações. Sabem que sua sobrevivência e a de sua cultura dependem do diálogo, da troca de conhecimentos e da interação com o mundo globalizado, embora preservando o seu modo tradicional de viver.

A abertura para o mundo externo pode contribuir para a aquisição de direitos básicos, não respeitados, como proteção de territórios, saúde e educação. Outra questão é a econômica: o extrativismo é uma das principais atividades, mas nem sempre as comunidades obtêm preço justo pelos produtos, muitos de grande valor e disputados no mercado internacional. (RPF, 2005) ${ }^{132}$

Sua história, da forma como é narrada, é uma grande aposta no futuro por um presente promissor cultivado pelo diálogo e pela abertura para o mundo como valorização de suas culturas. O passado é reconfigurado pelo presente: uma busca pela conexão de saberes, capaz de lançar suas sabedorias rumo ao mundo global por meio das antenas e dos fluxos informativos das redes digitais.

\subsection{4 "Agenda", "Clipping" e "Notícias e Ações"}

Essas três sessões do site foram agrupadas porque algumas das matérias (posts) publicadas citam as mesmas atividades. Elas apresentam, divulgam e anunciam atividades não só da Rede, como outras relacionadas aos povos indígenas no Brasil e aos povos tradicionais, desde o "Seminário de Políticas Públicas para Populações Tradicionais" aos festivais de cinema ambiental. Os lugares também são os mais diversos: o Espaço Tom Jobim, muitas atividades expositivas, concertos e shows, até ações globais, como aquela promovida pela WWF, convidando a todos a apagarem suas luzes como demonstração de preocupação pelo aquecimento global, ocorrida em 28 de março de 2009.

Na secção "Agenda", há divulgação de, sobretudo, exposições com os temas correlatos. Na "Notícias e Ações", são divulgadas as atividades relacionadas principalmente à implantação dos Pontos de Cultura Indígena (2009-2010). Essa parte do site foi a principal fonte para a elaboração da linha do tempo da Rede

\footnotetext{
${ }^{132}$ Post assinado por Gal Rocha. Disponível em: http://www.redepovosdafloresta.org.br/exibePagina. aspx?pag=30\&pagTipo=h. Acesso em: 23 out. 2011.
} 
Povos da Floresta, a ser apresentada na terceira parte deste capítulo. Finalmente, no "Clipping" várias matérias divulgadas nos principais jornais do país foram selecionadas, sempre recorrendo à pauta ambiental e dos povos tradicionais da Floresta. Em algumas há matérias sobre as atividades da Rede, em que a mídia nacional reconhece e parece apreciar o trabalho realizado pela RPF. É a secção com mais posts publicados (totalizando cem).

\subsection{5 "Pontos de Cultura Indígena"}

Nesta parte é apresentada a implantação dos trinta Pontos de Cultura Indígena ( $\mathrm{PCl})$, convênio assinado pela Rede por meio da Associação de Cultura e Meio Ambiente (representando-a juridicamente) com o Ministério da Cultura e a FUNAI com duração de dois anos (2009-2010). O objetivo dos PCls foi o de fornecer equipamentos e formação de registro audiovisual e de conexão à internet para as comunidades envolvidas, visando à disseminação de suas memórias e culturas. Isso viabiliza, com as interações com essas tecnologias comunicativas, novas formas audiovisuais de produção de narrativas locais, bem como o fortalecimento cultural dessas comunidades e de suas territorialidades.

Os esforços da RPF coincidiam com as políticas públicas de inclusão digital realizada pelo Ministério da Cultura na promoção da diversidade cultural, associada a uma cultura digital tipicamente brasileira. É singular a própria inserção do tema no MinC, na gestão de Gilberto Gil. Nas palavras de Claudio Prado, amigo de Gil e um dos idealizadores, a cultura digital entrava numa discussão mais global de cultura e política e, ao mesmo tempo, como ação de política pública:

Uma [frente de trabalho] era conceituar o digital como fenômeno cultural; discutir essa questão; ampliar essa questão; dialogar com o mundo que estava discutindo essas questões em diversos fóruns do mundo, aqui no Brasil e fora do Brasil. Isso era uma coisa. O que tornou isso consistente e forte foi a aplicação disso nos Pontos de Cultura. Porque aí você ia na outra ponta, no chão real das realidades locais, experimentando, com a possibilidade da cultura digital, modificar as realidades locais lá. (Claudio Prado, em entrevista à Eliane Costa - COSTA, 2011, p. 178) 
Os Pontos de Cultura, essa estrutura de produção audiovisual com conexão à internet em áreas de vulnerabilidade social, são uma ação prioritária do Programa Cultura Viva, baseado em três dimensões da cultura, na visão do MinC (2004 citado em COSTA, 2011, p. 60): a simbólica, a cidadã e a econômica. Para o MinC (2004), os Pontos fomentam "[...] uma intervenção aguda nas profundezas do Brasil urbano e rural, para despertar, estimular e projetar o que há de singular e mais positivo nas comunidades, nas periferias, nos quilombos, nas aldeias: a cultura local [...]".

Sua execução ocorre mediante editais "que convidam organizações não governamentais de caráter cultural e social, legalmente constituídas, e responsáveis por ações preexistentes há, pelo menos dois anos, a apresentarem propostas para participação e parceria" (COSTA, 2011, p. 179). Desde o primeiro edital publicado, em 2004, os Pontos foram compondo a referência de uma rede horizontal de articulação, recepção e disseminação de iniciativas e vontades locais.

Quanto aos Pontos de Cultura Indígena, uma ação mais específica com esses povos $^{133}$, firmava-se uma parceria entre o MinC, o Programa Cultura Viva e a FUNAI, dentro daquilo que ficou denominado como "Agenda Social dos Povos Indígenas" (2008-2010), coordenada pela instituição indigenista. Lançada em 21 de setembro de $2007^{134}$, foi uma série de ações que envolveram os direitos, a proteção das terras e a promoção social dos povos indígenas, considerando suas especificidades culturais e territoriais. Além da realização dessas ações, a Agenda objetivava potencializar, articular e integrar as ações do Estado, visando melhorar a atuação da FUNAI junto aos outros órgãos do Estado na execução de projetos sociais já desenvolvidos pelo governo e voltados para o benefício das populações indígenas $^{135}$. Previu-se, também, uma reestruturação da política indigenista com a criação da Comissão Nacional de Política Indigenista - CNPI - e dos Comitês Regionais paritários, espaços políticos estratégicos com a participação de

${ }^{133}$ Além dos Pontos de Cultura Indígenas, o MinC criou o Prêmio Culturas Indígenas, valorizando a revitalização de práticas e expressões culturais dos povos indígenas.

134 Nesse mesmo ano é publicado o Decreto n. 6.040/2007, instituindo a Política Nacional de Desenvolvimento Sustentável dos Povos e Comunidades Tradicionais, passando o Governo Federal a reconhecer as especificidades dos povos indígenas e das comunidades ribeirinhas, quilombolas, definindo-os pelos seus aspectos culturais e territoriais de reprodução de suas tradições (BRASIL, Governo Federal, Decreto n. 6040/2007).

135 Dos projetos existentes do governo, foram aplicados e continuam em andamento a Bolsa Família e o registro civil de nascimento e documentação básica (Registro Geral, Cadastro Pessoa Física e Carteira de Trabalho e Previdência Social) (VERDUM, 2011). O programa de transferência de renda é particularmente polêmico porque associa os índios à vulnerabilidade econômica, fortalecendo o vínculo e a dependência do Estado. 
representantes indígenas e do governo para a concertação de políticas públicas voltadas para esses povos. Todas essas ações estavam integradas ao Programa de Promoção e Proteção dos Povos Indígenas do Programa Plurianual 2008-2011.

Como um mediador na relação entre Estado e sociedade, a implantação dos Pontos de Cultura conseguiu agregar e potencializar as ações da RPF nas comunidades indígenas envolvidas, suas produções audiovisuais e sua difusão e circulação. Cada comunidade selecionada recebeu um kit multimídia com três computadores com DVD embutido, uma câmera filmadora, uma câmera fotográfica digital, duas caixas de som e um microfone.

Se esse convênio representou a ação mais importante e ambiciosa da RPF pelo volume de comunidades beneficiadas e pela logística demandada para sua execução, ele trouxe também um grande divisor de águas na sua trajetória. A RPF conduzia, até aquele momento, ações envolvendo várias comunidades tradicionais, entre elas a dos seringueiros e quilombolas. Com a assinatura de convênio com o MinC e o Programa Cultura Viva, a Rede volta-se, sobretudo, para ações em comunidades indígenas. Paradoxalmente, o Centro Yorenka Ãtame, um dos beneficiários dessa parceria com o programa governamental, idealizado pelos Ashaninka, seria o único espaço contemplado pelo projeto que abarcaria o público indígena e não indígena.

Após a assinatura do convênio, em 2009, todas as ações da RPF passaram a se concentrar na implantação dos trinta Pontos de Culturas, em cinco estados do país: Acre, Amazonas, Mato Grosso, Rondônia e Roraima. Foram inclusas as comunidades e aldeias demarcadas que já tinham contato com a RPF. Inicialmente, foram realizadas Rodas de Conversa, no intuito de "mobilizar, apresentar e validar a iniciativa junto às lideranças indígenas" (RPF, 2009). Havia uma preocupação de respeitar a autodeterminação e as especificidades das comunidades, e as Rodas seriam esse espaço de conversa e expressão.

Devido à abrangência e às dificuldades de acesso a algumas regiões, as áreas contempladas foram subdividas em três polos de atuação:

Pólo 1: Pari-cachoeira, Taracuá, Balaio, lauaretê, Cucuí, Escola Kariamã, Associação das Comunidades Indígenas do Médio Rio Negro, Associação Indígena de Barcelos, Aldeia Watoriki-Theri e Associação Hutukara.

Pólo 2: Nova Esperança, Mutum, Três Fazendas, Novo Segredo, Kaxinawá do Rio Humaitá, Lapetanha , Apoena Meireles, Ricardo 
Franco, Comissão Pró-Índio do Acre e Centro de Memória - Rio Jordão.

Pólo 3: Centro Yorenka Ãtame, Buritizal, Sete Estrelas, Cruzeirinho, Jacobina, Katukina do Campinas, Poyanawa do Barão, República Nukini Igarapé, Vida Nova e Organização dos Povos Indígenas do Rio Juruá.

Nesses pontos vivem as etnias Tukano, Yanomami, Yawanawá, Kaxinawá, Suruí, Jaboti, Jaminawa, Kontanawa, Katukina, Poyanawa, Marubo e Nukini. (RPF, 2009) ${ }^{136}$

As etapas de implantação dos $\mathrm{PCl}$ envolveram: rodas de conversas com a comunidade envolvida; oficinas de práticas digitais; implantação dos equipamentos e oficinas de formação audiovisual e edição. As duas últimas foram assessoradas pela equipe do Vídeo nas Aldeias, organização fundada em 1987 por Vincent Carelli, dentro das atividades da ONG Centro de Trabalho Indigenista (CTI). Desde então, o Vídeo nas Aldeias tem um papel fundamental no trabalho colaborativo de registro audiovisual das narrativas e das percepções dos povos brasileiros. Em outra oportunidade pude descrever brevemente o trabalho deles (PEREIRA, 2010).

\subsection{6 "Galeria de fotos"}

Esta parte, como se espera, é o espaço das fotos da Rede Povos da Floresta no período de implantação dos Pontos de Cultura Indígena. É um rico arquivo fotográfico, dividido em dois grandes arquivos. O primeiro, intitulado "RPF em ação", com os álbuns "Formação em edição", "Formação em Audiovisual", "Implantação PCl's", "Comunidades", "Formação digital", "Rodas de conversa", "Centro Yorenka Ãtame", "Eventos" e "Festas tradicionais". Cada um desses álbuns possui subpastas associadas às localidades das atividades realizadas. As imagens mostram 0 andamento das atividades, as comunidades manuseando os equipamentos, trabalhando junto aos coordenadores e assessores das oficinas, fazendo campo, captando também imagens, recebendo os certificados ao final de cada oficina e assinando o termo de responsabilidade de cada Ponto de Cultura implantado.

\footnotetext{
136 Disponível em: http://www.redepovosdafloresta.org.br/exibePagina.aspx?pag=138\&pagTipo=n
} Acesso em: 15 nov. 2011. 
O segundo arquivo, "Making of Rio Jordão, Novo Segredo e Yorenka Ãtame", "Implantação PCl's", "Rodas de conversa", "Instalação de antenas em Marechal Thaumaturgo". Esse arquivo, também composto de subpastas, mostra a chegada dos equipamentos, o trabalho da equipe, o lugar, a descontração. A maioria das fotos é da fotógrafa Alice Fortes, filha de João Fortes. As imagens são primorosas, enchem os olhos e nos levam até o processo de implantação dos PCl's.

O que mais me chamou a atenção nesse momento soberbamente imagético das atividades da Rede Povos da Floresta foi por ele ter sido um trabalho feito principalmente por mulheres. Elas tiveram um papel fundamental, porque estavam envolvidas diretamente na implantação, na parte mais desafiadora, no transporte dos equipamentos, na montagem da estrutura, nos deslocamentos, etapas marcadas pelas adversidades mais óbvias que envolvem a logística de um empreendimento na Floresta. Era, além da fotógrafa, Alice Fortes, um grupo feminino composto por Vírginia Barbosa Gandres (coordenadora de campo), Dominique Aguiar, Deborah Castor e Mary Bastos (assessoras de campo). Além delas, compuseram esse time, nas etapas de formação audiovisual e edição, as assessoras da equipe do Vídeo nas Aldeias, Ana Carvalho, Carolina Canguçu, Julia Barreto e Camila Machado.

Desse extenso acervo, selecionei uma foto que me pareceu transpor o cruzamento de olhares diante do acontecimento técnico: a chegada de computadores na Aldeia Yanomami Demini, Amazonas (2009). A foto, captada por Alice Fortes, tem a única identificação: "Ponto de cultura Demini". Nela estão muitas jovens mulheres, crianças e rapazes Yanomami, que prestam à atenção ao que um gestor indígena diz. Ao mesmo tempo, olham para o monitor do computador que, por sua vez, tem imagens de pessoas na tela. Vírginia Gandres, de costa para o monitor e de frente para o grupo, sorri, vendo como eles olham e observam atentamente a tela do computador e o rapaz. Dominque Aguiar, ao lado de Vírginia, olha a câmera de Alice. Ela olha para nossos olhos, como quem pensa sorrindo: "Olha que encontro extraordinário!". 


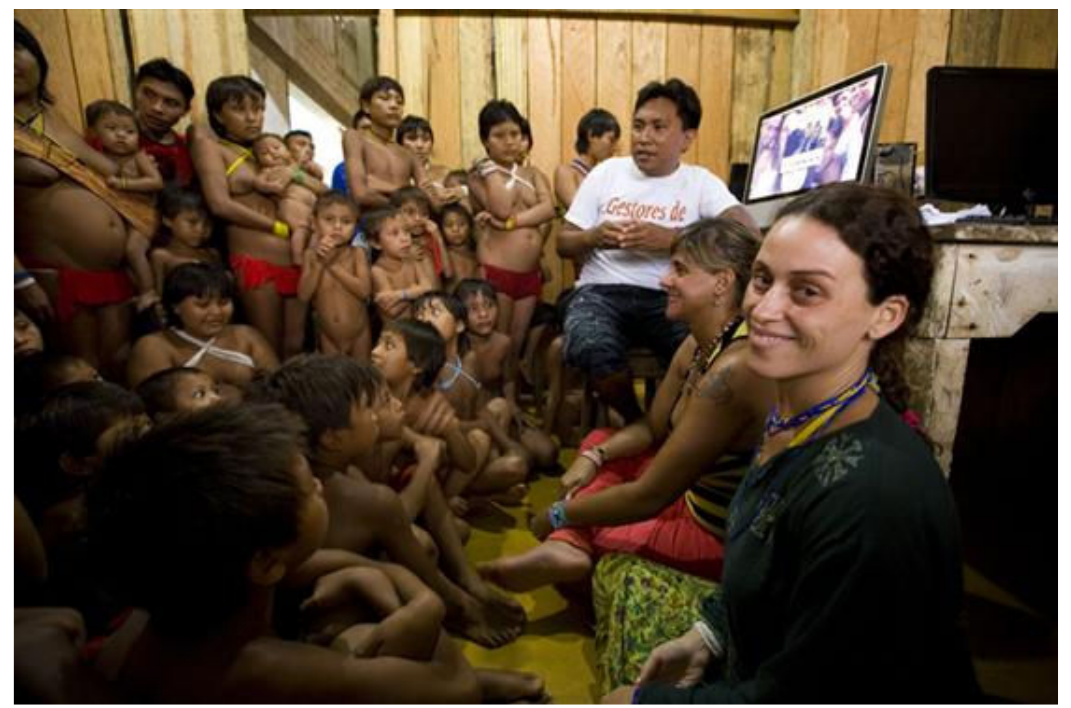

Figura 3 - Foto de Alice Fortes - Ponto de Cultura Demini

\subsection{7 "Galeria de vídeos"}

Oito vídeos compõem esta secção. O vídeo "A gente luta mas come fruta", produzido pelos Ashaninka do Rio Amônia, com o Vídeo nas Aldeias (2006, 39 min.), dividido em cinco partes, disponível no Youtube; bem como o vídeo de apresentação do Centro Yorenka Ãtame ${ }^{137}$ (2008) e do próprio coordenador da RPF, Ailton Krenak $^{138}$ (2010); e o registro audiovisual da Roda de Conversa ${ }^{139}$ (2009) entre os parceiros da Rede para implantação do PCls.

O conteúdo dos vídeos de Ailton Krenak, do Centro Yorenka Ãtame e da Roda de Conversa me auxiliaram a compor a cronologia de desenvolvimento da Rede, a ser apresentada no item 3.3 deste capítulo, quando discorro, a partir de uma linha do tempo, sobre as associações e os tecno-atores da Rede.

Detenho-me na análise do vídeo "A gente luta mas come fruta", resultado de uma das oficinas realizadas em 2004 em parceria com o Vídeo nas Aldeias. Nesse mesmo período, os Ashaninka produziram o vídeo "Caminho para a vida, aprendizes

${ }^{137}$ O vídeo de apresentação do Centro Yorenka Ãtame foi produzido pela jornalista e participante da Rede Povos da Floresta, Stefania Fernandes (2008). (duração: 6min e 45 seg).

${ }^{138}$ Entrevista gravada com Ailton Krenak em 2010, no estúdio Cine \& Vídeo, em São Paulo (duração: 5 min. e 54 seg).

139 Essa "Roda de Conversa" foi um encontro realizado no Rio de Janeiro em outubro de 2009 entre todos os parceiros da Rede em que se discutiram as formas e estratégias de implantação e montagem dos equipamentos nos futuros Pontos de Culturas. 
do futuro, Floresta Viva" (2004), dirigido por Benki ${ }^{140}$. Ambos são documentários sobre seu trabalho de manejo e reflorestamento na Aldeia Apiwtxa. Eles reflorestam com sementes de mogno, cedro e árvores frutíferas, comem as frutas que plantam e pela floresta lutam. Relação exemplar de um ecossistema também informativo, a cujo registro soma-se uma ação tecnossocial de reconhecimento. Um manifesto audiovisual a favor do ambiente que todos, humanos e não humanos, compõem o substrato. O terçado (facão) que corta as bananeiras para a compostagem, os plásticos dos saquinhos que 'guardam' as sementes até tornarem-se mudas, as crianças vestidas com as kusmas ${ }^{141}$ aprendem com Benki esse processo, com seus sorrisos caminham com as mudas crescidas; a câmera registra essas imagens em movimento e com elas forma um todo: uma espacialidade informativa de atoresredes envolvidos em suas interações e interdependências.

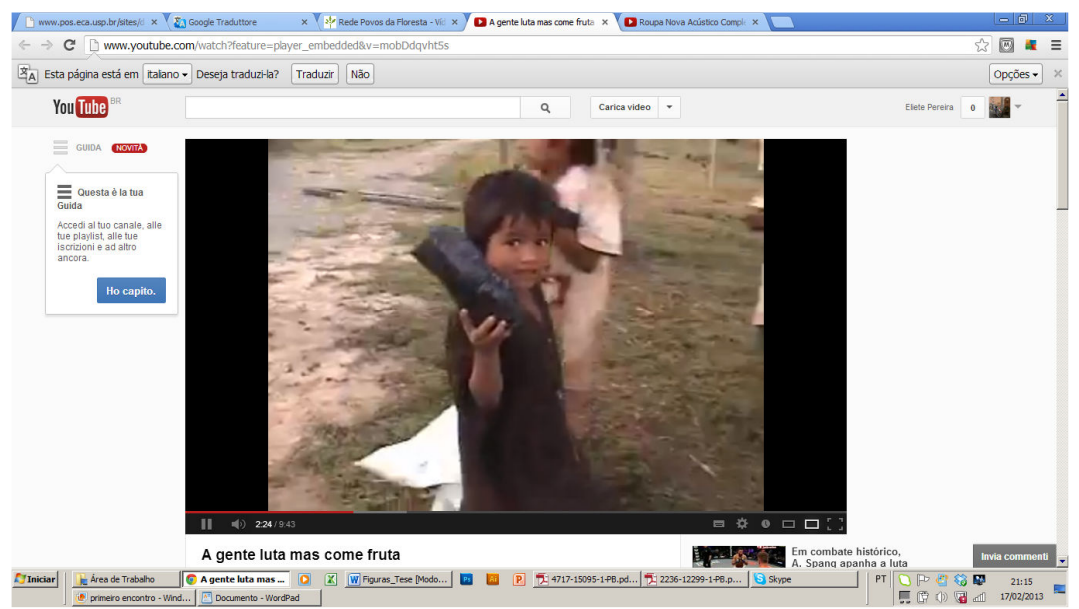

Figura 4 - Captura de trecho do Vídeo "A gente luta mas come fruta" (2006)

No "A gente luta mas come fruta" mostram, sobretudo, o envolvimento da comunidade nessas atividades, das crianças aos adultos, que trabalham também na construção de um açude para a criação de tracajás (também chamado de quelônio, espécie de tartaruga muito apreciada por eles e quase extinta nos anos 1990). Além disso, narra o conflito com os invasores madeireiros de suas terras: a descoberta da invasão, a denúncia via rádio contra eles e a chegada do então governador do Acre,

\footnotetext{
${ }^{140}$ Esses vídeos estão disponíveis no DVD Cineastas indígenas - Ashaninka, produzido pelo Vídeo nas Aldeias. No total estão disponíveis: "Shomõtsi" (2001, 42 min.), "A gente luta mas come fruta" (2006, $39 \mathrm{~min}$.), "No tempo da chuva (2000, $38 \mathrm{~min}$.), "Caminho para a vida, aprendizes do futuro, Floresta Viva" (2004, 36 min.).

${ }^{141}$ As kusmas (em quéchua) são os vestidos de algodão tradicionais Ashaninka feitos em tear pelas mulheres.
} 
Jorge Viana, com representantes do IBAMA, da FUNAI e do Exército para uma reunião com a comunidade Ashaninka do Amônia ${ }^{142}$. Na ocasião, Isaac Pianko afirma a necessidade de uma estratégia conjunta entre a comunidade e os governos brasileiro e peruano por se tratar de uma região transfronteiriça. $O$ governador se compromete a levar o problema para uma reunião com o governo peruano. Em seguida, o vídeo mostra a ação do exército brasileiro junto aos Ashaninka, e o comentário de um soldado ao contar sobre a prisão de peruanos envolvidos na derrubada de madeira.

Em todo o documentário vêm-se as preocupações desse povo para com a manutenção da Floresta, porque dela dependem por conta da caça, da pesca, da flora, e, ainda, de seus espíritos. Tal relação ecológica é imprescindível em suas cosmologias e será discutida no próximo capítulo.

\subsection{8 "Rede Digital"}

Constitui a primeira grande atividade de conexão dessas comunidades, em 2005, com a instalação de infraestrutura em oito pontos da Rede: Comunidade Kontanawa do Sete Estrela - Rio Tejo; Aldeia Kaxinawa do Breu - Comunidade Jacobina; Comunidade Belford - Rio Juruá; Vila Foz do Breu - Rio Juruá (distrito do município de Marechal Taumaturgo); Centro Yorenka Ãtame - Saberes da Floresta Centro de Intercâmbio de Conhecimento (município de Marechal Thaumaturgo); Aldeia Apiwtxa (Ashaninka) - Rio Amônia; Foz do Bagé - Rio Bagé; Vila Restauração - Rio Tejo. Não há informações de quantas pessoas se envolveram diretamente com as atividades de inclusão digital, mas certamente ali começou a ser plantada a semente da conexão.

Esses primeiros "fios" foram tecidos com a parceria da RPF (representada pela Associação de Cultura e Meio Ambiente) com o GESAC - Governo Eletrônico: Sistema de Apoio ao Cidadão - do Ministério das Comunicações e do Ministério do Meio Ambiente, governo federal, que instalaram os pontos de conexão via satélite.

\footnotetext{
${ }^{142}$ Nesse encontro registrado por eles é visível o prestígio da família Pianko com as autoridades. À direita do governador está o representante do Exército, e, à sua esquerda, Antonio Pianko e Dona Piti, ao redor os filhos e toda a comunidade Ashaninka.
} 


\subsection{9 "Reflorestamento"}

Nesta parte, destaca-se uma das principais atividades da Rede, que envolve o reflorestamento das áreas desmatadas, com o Projeto Nanapini (projeto no momento desativado) e com o trabalho de sistemas agroflorestais realizado pelo Centro Yorenka Ãtame.

O reflorestamento é a atividade de replantar florestas que já existiram, mas que, por alguma razão, foram extintas. A intenção ao reflorestar uma determinada área, é reconstituir o mais parecido possível com seu estado natural a fim de preservar os lençóis freáticos, o solo e até mesmo a qualidade do ar.

Há muito as florestas sofrem com a exploração predatória, seja pela retirada ilegal de madeira ou por causa das queimadas. $O$ desaparecimento de espécies animais, a escassez de água e o aquecimento global são algumas das consequências dessa exploração. (RPF, s/d) $)^{143}$

Os sistemas agroflorestais são formas de uso e manejo da terra priorizando o plantio de árvores frutíferas da região (de pupunha, de açaí, etc.) e de árvores de madeira de lei (cedro, mogno, etc.), priorizando um equilíbrio entre a fauna e o plantio de subsistência.

\subsubsection{0 "Buscas", "links" e "Fale conosco"}

É possível fazer uma busca temática pela arquitetura informativa do site. Nos "Links" há uma lista de instituições, entre elas a FUNAI, o Instituto Socioambiental, entre outras que estão envolvidos diretamente com os povos indígenas e com as comunidades tradicionais. Contudo, nem todas as instituições citadas são parceiras diretas da Rede. No "Fale conosco" pode-se preencher um formulário e enviá-lo diretamente aos coordenadores da Rede. Em 2009, realizei minha primeira tentativa de contactar o grupo. Interessava-me realizar uma entrevista com seu coordenador, Ailton Krenak. Preenchi o formulário e enviei. Não obtive resposta. Enviei um e-mail

${ }^{143}$ Disponível em: http://www.redepovosdafloresta.org.br/gerExi.aspx?kwd=8. Acesso em: 21 nov. 2011. 
para o correio eletrônico da Rede informado no site, igualmente sem resposta. Parti para a localização do perfil de Ailton Krenak no Facebook. Lá consegui realizar uma entrevista com ele e também com Gal Rocha, a jornalista que escreveu parte dos posts do site.

O contato com Benki Pianko ocorreu por meio do colega do Centro de Pesquisa Atopos, Fábio Munhoz ${ }^{144}$, após a participação dele no Encontro de Saberes, em Brasília, no ano de 2009. Em 2011, fiz o primeiro contato, objetivando uma visita ao Centro Yorenka Ãtame. Em 2012, mantive vários contatos telefônicos, inclusive realizei, em um desses telefonemas, uma entrevista de quarenta minutos com Benki. Em novembro, consegui finalmente visitar o Yorenka, tendo a oportunidade de com ele realizar uma entrevista gravada de uma hora e trinta minutos, além de contactar outras pessoas que participaram da Rede.

\subsection{CRONOLOGIA DAS ASSOCIAÇÕES E DOS ATORES-REDES}

Partindo dos diversos posts do site ${ }^{145}$ e da conversa realizada com Ailton Krenak, Benki Pianko e outros participantes da Rede ${ }^{146}$, pontuei os principais marcos da construção, elaboração e consolidação da RPF.

Em 2003, com o apoio do Comitê para a Democratização da Informática e da empresa StarOne, a Rede começa a realizar seu trabalho de articulação com as comunidades da Amazônia para a implantação de Internet. No mesmo ano, em matéria exibida pelo programa Fantástico, da Rede Globo, em 14 de setembro de 2003, presente na secção "Clipping" do site da RPF, são registradas as primeiras impressões da chegada da Internet nas aldeias:

\footnotetext{
${ }^{144}$ Fábio Munhoz havia conhecido Benki após participar da primeira etapa do "Encontro de Saberes", em 2009, em Brasília, um projeto da Universidade de Brasília e do Ministério da Cultura com o objetivo de trazer o conhecimento das populações tradicionais para a Universidade com o oferecimento de uma disciplina na graduação, ministrada pelos principais mestres dos saberes tradicionais do país.

${ }^{145}$ Foram publicados 222 posts entre 2003 a 24 de maio de 2011, data do último post registrado até a finalização deste capítulo. Nesse período, os anos de 2009 e 2010 tiveram atualizações mais frequentes (cerca de $70 \%$ dos posts publicados), momento que coincide com a instalação dos Pontos de Cultura Indígena, uma parceria entre a Associação de Cultura e Meio Ambiente, o Ministério da Cultura e a FUNAI.

${ }^{146}$ Entre eles, Gal Rocha e o assessor técnico da Associação Apiwtxa do Amônia, Gleyson Teixeira.
} 
"Isso daqui vai trazer o sinal que vem do satélite. Aí dali o senhor consegue falar com todas as aldeias", explica o técnico para o pajé.

"Para vocês, como técnicos, vejo uma coisa pequena ainda... Inauguramos um sistema numa comunidade. Mas nós temos um olhar muito maior. Você está dando um instrumento para o fortalecimento do povo indígena nesse país", observa Ixiúca, membro da liderança Yawanawa.

"A gente quer aprender toda essa tecnologia que está chegando à nossa aldeia para ter esse mundo de comunicação. Porque para nós é muito importante saber o que está acontecendo lá fora e transmitir o que estamos vivendo aqui também", diz o membro da liderança Ashaninka, Benki Pinhanta ${ }^{147}$.

Em 2004, os Ashaninka já tinham instalado a Internet na aldeia Apiwtxa, o que lhe possibilitou denunciar as invasões em suas terras por madeireiros peruanos. Tal denúncia foi enviada por Benki Pianko via e-mail, chegando ao governo federal e às redações dos principais jornais. Em poucos dias, o Exército, o governador Jorge Viana e a televisão estavam lá, tendo sido o encontro registrado por eles no documentário disponível no site da RPF "A gente luta mas come fruta" (2006), dirigido por Bebito e Isaac Pianko, com imagens realizadas por Bebito, Isaac, Benki, Tsirotsi, Hatã e Enisson, um trabalho resultado da parceria com o Vídeo nas Aldeias.

Até 2005 terão o apoio do GESAC - Governo Eletrônico: Sistema de Apoio ao Cidadão do Ministério - das Comunicações e do Ministério do Meio Ambiente, do governo federal, com a instalação dos pontos de conexão via satélite em aldeias e comunidades ribeirinhas, abrangendo a Rede Povos da Floresta (RPF) em oitos pontos, já citados ${ }^{148}$. Realiza-se, em junho, o $1^{\circ}$ Seminário Rede Povos da Floresta, no Rio de Janeiro, com a participação de todos os membros da Rede e, em seguida, no final do ano, acontece uma reunião para planos de expansão da Rede com a participação de Álvaro Tukano, Eliane Potiguara e José Paixão, do Conselho das Comunidades Afrodescendentes do Amapá, junto com o coordenador do projeto Áreas Protegidas da Amazônia (ARPA), Ronaldo Weigand, e o representante do Programa Nacional de Educação Ambiental (ProNEA), Francisco de Assis Morais, ambos do Ministério do Meio Ambiente, e João Fortes, da Associação de Cultura e

\footnotetext{
147 Disponível em: http://redepovosdafloresta.org.br/exibePagina.aspx?pag=54\&pagTipo=c. Acesso em: 11 nov. 2011.

148 Os pontos de conexão digital abrangeram as Comunidade Kontanawa do Sete Estrela - Rio Tejo; Aldeia Kaxinawa do Breu - Comunidade Jacobina; Comunidade Belford - Rio Juruá; Vila Foz do Breu - Rio Juruá (distrito do município de Marechal Taumaturgo); Centro Yorenka Ãtame Saberes da Floresta - Centro de Intercâmbio de Conhecimento (município de Marechal Thaumaturgo); Aldeia Apiwtxa (Ashaninka) - Rio Amônia; Foz do Bagé - Rio Bagé; Vila Restauração - Rio Tejo.
} 
Meio Ambiente (ACMA), responsáveis pela articulação do Ministério do Meio Ambiente, do Ministério das Comunicações e do Ministério do Planejamento com as diversas comunidades locais.

Naquele ano, após participar do Ano do Brasil na França, no show do cantor Leoni em Paris, Benki Pianko começa a articulação de apoiadores para a construção do Centro Yorenka Ãtame (Escola Saberes da Floresta) até o ano seguinte. Em menos de dois anos consegue arrecadar quase um milhão de reais, viabilizando a compra do terreno e a construção do espaço. Em 07 de abril de 2007 este é inaugurado, com a presença de mais de trezentas pessoas entre população local, convidados e parceiros nacionais e internacionais (PIMENTA, 2007). Em 24 de novembro de 2007, a Internet chega ao Centro com a RPF, via GESAC e Ministérios do Meio Ambiente e Comunicações. No mesmo ano, a RPF se expande para comunidades indígenas, quilombolas e caiçaras de Parati e Ilha Grande (RJ).

Uma série de encontros com representantes do Ministério da Cultura e entre membros da Rede serão realizados em 2008. A visita do secretário de Incentivo e Fomento à Cultura, Roberto Nascimento, de Políticas Culturais, Alfredo Manevy, do MinC, ao Yorenka e à aldeia Ashaninka começa a delinear uma futura parceria, potencializando o trabalho de valorização da diversidade cultural realizada pela RPF e pelos Ashaninka. No mesmo período, fevereiro, realiza-se a viagem de articulação para acompanhamento do cronograma de mobilização e implantação da Rede Digital de Monitoriamento, Vigilância e Educação Ambiental nos estados de Mato Grosso e Rondônia, com a participação de um grupo de suíços e ingleses. Posteriormente, a Associação Metareilá, do Povo Indígena Suruí, representada por Almir Suruí, elaborará o Projeto de Carbono Florestal Suruí (PCFS), com o apoio de várias organizações, mapeamento e monitoriamento de seu território por meio do Google Earth e de sua parceria com o Google Outreach, braço social do Google.

Em seguida, em Brasília, ocorre o encontro com Gilberto $\mathrm{Gil}^{149}{ }^{14}$ Roberto Nascimento, Secretário de Incentivo e Fomento à cultura do MinC, Ailton Krenak, João Fortes, José Paixão, Isaac e Benki Ashaninka, dando prosseguimento ao interesse do MinC em firmar um convênio com a Rede. Na continuidade de sua expansão, novas antenas do GESAC são instaladas no município de Marechal

\footnotetext{
149 Uma comitiva do Ministério da Cultura, com a participação do Ministro Gilberto Gil, visitará o Yorenka Ãtame e a aldeia Ashaninka em maio de 2008. É a primeira vez que uma autoridade do primeiro escalão do governo visita a região.
} 
Thaumaturgo e é inaugurada, em maio de 2008, a sede da RPF no Rio de Janeiro, no Espaço Tom Jobim. Em 09 de outubro, nesse mesmo espaço, se realiza o Encontro da Rede Povos da Floresta para a avaliação dos trabalhos. Estavam presentes Ailton Krenak, João Fortes, Benki e Moisés Pianko, Rodrigo Baggio (CDI), Victor Fasano, Cynthia Howlett, entre outros. Ali se começava a discutir a parceria com o Ministério da Cultura. Ainda nesse ano Ailton Krenak recebe o Prêmio Chico Mendes de Florestania, no Acre. A Rede Povos da Floresta também é homenageada no $10^{\circ}$ Encontro da Rede CDI - Comitê para a Democratização da Informática, realizado em Nova Friburgo (RJ).

O ano de 2009 constituiu o grande marco da trajetória RPF. A Rede assina o convênio, por meio da Associação de Cultura e Meio Ambiente (representando juridicamente a Rede), com o Ministério da Cultura e a FUNAI, para a instalação de trinta Pontos de Cultura Indígena ( $\mathrm{PCl}$ ). $\mathrm{O}$ objetivo foi fornecer equipamentos e formação de registro audiovisual e de conexão à internet para as comunidades envolvidas, visando a disseminação de suas memórias e culturas. Ainda, se buscava viabilizar, pelas interações com essas tecnologias comunicativas, novas formas audiovisuais de produção de narrativas locais, fortalecimento cultural dessas comunidades e de suas territorialidades.

Após a assinatura do convênio, em 2009, todas as ações da RPF concentraram-se na implantação dos trinta Pontos de Culturas, em cinco estados do país - Acre, Amazonas, Mato Grosso, Rondônia e Roraima. Foram incluídas as comunidades e aldeias demarcadas que já tinham contato com a RPF. Inicialmente, foram realizadas as Rodas de Conversa, no intuito de "mobilizar, apresentar e validar a iniciativa junto às lideranças indígenas" (RPF, 2009). Havia uma preocupação de respeitar a autodeterminação e as especificidades das comunidades, e as Rodas seriam esse espaço de conversa e expressão.

No post assinado por Gal Rocha no dia 09 de maio de 2009, durante a Primeira Roda de Conversa ${ }^{150}$ com todos os parceiros do projeto, no Espaço Tom Jobim (RJ), essa preocupação e cuidado eram evidentes:

A Roda vai reunir as comunidades que serão beneficiadas em diferentes locais para uma conversa com os responsáveis pela implantação, nela o projeto será apresentado em detalhes e as

\footnotetext{
${ }^{150}$ No site da RPF e no Youtube encontra-se disponível o vídeo com trechos da Primeira Roda de Conversa (2009): http://www.youtube.com/watch?feature=player_embedded\&v=9un2RiCcasw.
} 
comunidades terão a oportunidade de expressar seus pensamentos e anseios em relação a ele. Ailton afirmou que as rodas não são cartesianas e não têm fim, ao contrário, são circulares, platônicas, infinitas.

Ficou claro para todos os presentes que em cada Roda de Conversa que se realizará, será definido o que é o ponto de cultura para aquela determinada comunidade e que cada ponto tem sua própria identidade, sem precisar reproduzir ou seguir uma norma. Cada um desses pontos deve expressar a complexidade local e para isso, cada comunidade dirá o que quer e o que não quer socializar. $O$ projeto não pretende implantar réplicas, como numa linha de montagem. (Gal Rocha, RPF, 2009) ${ }^{151}$.

Essa Primeira Roda de Conversa, realizada de 05 a 08 de maio de 2009, foi um importante encontro entre os parceiros para acertar a logística de instalação dos equipamentos. Estavam presentes como membros da RPF, Benki e Moisés Pianko, João Fortes, Virginia Gandres, Ailton Krenak, além de Erivaldo Almeida Cruz, diretor da Federação das Organizações Indígenas do Rio Negro (FOIRN), Andreza Andrade, jornalista do Instituto Sócio Ambiental (ISA); Vera Olinda Sena, Comissão Pró-Índio do Acre, Gleyson de Araújo Teixeira, assessor da Associação Ashaninka Apiwtxa, André Abreu, Fundação France Liberté, Paulo Jobim, da Associação de Cultura e Meio Ambiente, e Rodrigo Baggio, do Comitê de Democratização da Informática (CDI) (RPF, 2009).

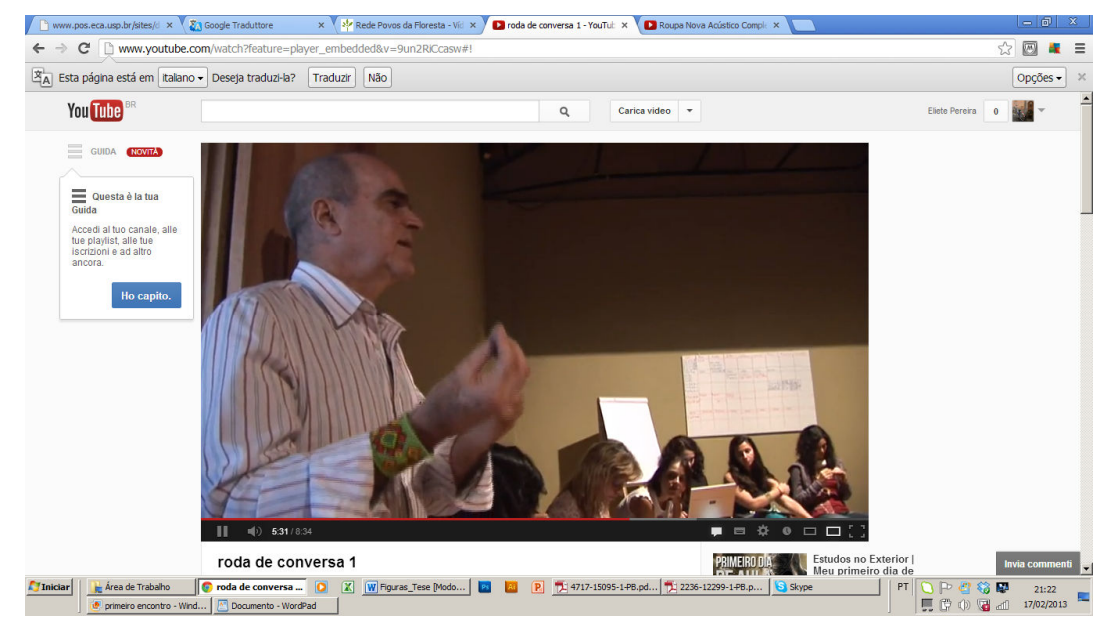

Figura 5 - Captura de trecho do vídeo da Primeira Roda de Conversa - João Fortes em primeiro plano ${ }^{152}$.

\footnotetext{
151 Disponível em: http://www.redepovosdafloresta.org.br/exibePagina.aspx?pag=138\&pagTipo=n Acesso em: 15 nov. 2011.

152 O vídeo da Primeira Roda de Conversa (2009) da RPF realizada no Espaço Tom Jobim (RJ) foi produzido por Thomas Schwierskott.
} 
Na ocasião dessa Roda, Ailton Krenak expõe o que significa atuar em rede: "[é] ser capaz de estabelecer uma dinâmica, interagir sem uma ordem de comando, mas respondendo aos estímulos e sinais que cada um consegue ler e responder [...] isso cria um texto, uma narrativa, que vem a ser a própria vida [...] uma cama de gato, rede de pesca, de balanço, de balaio." (RPF, 2009) ${ }^{153}$.

Essa analogia poética descrita por Ailton parece convergir para aquela percepção da Rede como morfologicamente descentralizada, sendo seus fluxos impulsos energéticos textualizados para uma ação corrente sem a linearidade de resposta a um comando centralizador. Embora a organização das equipes para a implantação dos Pontos tenha ocorrido no Rio de Janeiro, com o grupo articulado por João Fortes e Ailton Krenak, é visível, nesta Roda de Conversa e durante o trabalho de implantação, o constante diálogo com todos os envolvidos, principalmente as comunidades a serem beneficiadas com os equipamentos e as oficinas.

Um grande encontro de pessoas sensíveis e comprometidas com um projeto complexo, numa região de difícil acesso, onde a "Natureza", a "Floresta", é mais que significante de um território, é agente importante da Rede. Isto é, tal implantação dos Pontos não é uma ação unilateral: vem precedida de uma série de articulações, contatos, fluxos informativos que não se dão somente entre os "atores" humanos. Além de dispositivos técnicos móveis e conexões invisíveis, celulares, computadores, acesso à Internet e programas (softwares), a Floresta é uma agente essencial da Rede e, por sua vez, todos os seus organismos vivos estão arranjados em forma de rede. É um sistema vivo reticular por excelência; seu composto mais expressivo, como rios, clima, vegetação, animais, não são objetos passivos dessa ação, mas actantes, cuja existência compõe uma dinâmica relacional fundamental.

Considerando que os próprios povos habitantes dela fazem parte desse ecossistema reticular, são eles os principais "leitores" e "intérpretes", bem como seus "negociadores". O clima, as chuvas interferem nas "cheias", portanto, na subida e descida dos rios. Os equipamentos maiores, como antenas, chegavam através das embarcações. Sem os rios, seus cursos, afluentes, não haveria a mínima possibilidade de realização da conexão com regiões onde não há pista para pouso e decolagem de aviões de pequeno porte. A própria luz solar, matéria-prima para a

$\overline{153}$ http://www.redepovosdafloresta.org.br/exibePagina.aspx?pag=138\&pagTipo=n. Acesso em 15 de novembro de 2011. 
produção de energia, é um elemento fundamental (os equipamentos são operados por energia solar). A existência da vegetação, seu processo de fotossíntese e transpiração regula a condição climática que, por sua vez, provocam as chuvas e enchem os rios. Dito tudo isso, de forma bastante simplista, esse ecossistema, a Floresta, é pura agencialidade em rede, e o êxito dos trabalhos da RPF dependeu muito dela. Ninguém é soberbo o bastante para brincar com a natureza sem antes pedir licença, negociar e tentar observá-la (vendo o céu, as nuvens, as estrelas e a vegetação) ${ }^{154}$. Fora a existência das suas entidades supravisíveis, a jiboia (elemento recorrente da miração ${ }^{155}$ sob efeito da Ayahuasca ${ }^{156}$ ), Pawá (Deus criador para os Ashaninka), entre outros.

Dada a abrangência e as dificuldades de acesso a algumas regiões, as áreas contempladas foram subdividas em três polos de atuação, já mencionados anteriormente. O planejamento acordado entre o grupo abrangeu três etapas de implantação dos $\mathrm{PCl}$ : rodas de conversa em pontos estratégicos da rede; cursos de formação de práticas digitais; implantanção da infraestrutura (equipamentos); e, por último, a realização de oficinas de formação em audiovisual e edição com a participação da equipe do Vídeo nas Aldeias.

$\mathrm{Na}$ primeira etapa de implantação dos $\mathrm{PCl}$, outras rodas de conversas foram realizadas em 2009 em três pontos estratégicos da Rede: Comissão Pró Índio, em Rio Branco (AC); Centro Yorenka Ãtame, município de Marechal Thaumaturgo (AC), Federação das Organizações Indígenas do Rio Negro (FOIRN), em São Gabriel da Cachoeira (AM). O objetivo era reunir-se com as lideranças locais para 0 detalhamento do projeto.

Na segunda etapa, foram realizados cursos de formação de práticas digitais de 03 a 18 de agosto de 2009, em Rio Branco (AC) e São Gabriel da Cachoeira (AM). Participaram do curso em São Gabriel da Cachoeira (AM): a coordenadora da formação, Mary Bastos, e os técnicos Elizabete Morais, do ISA, e Marcos Albino, da

154 Os Ashaninka, por exemplo, como todos os povos associados aos ecossistemas 'naturais' baseiam seus calendários a partir da observação da vegetação e dos animais.

${ }^{155}$ A miração é uma visão reveladora de conteúdo psicossocial para quem está sob o efeito da bebida Ayahuasca, um chá preparado com o caule do cipó jagube (Banisteriopsis caapi) e das folhas da chacrona ou rainha (Psychotria spp.). O uso do chá é muito difundido entre os xamãs Ashaninka, que a chamam de Kamarãpi. No contato com os seringueiros e as populações regionais, o chá passou a ser utilizado nos rituais espirituais de diversas comunidades. Entre essas, destacam-se a União do Vegetal, a Barquinha e o Santo Daime.

156 De origem quechua, a etmologia da palavra é: Aya = pessoa, alma, espírito; e Wasca = corda, trapadeira (enredadera), parra, liana, cipó. Ou seja, cipó das almas ou corda dos espíritos (LESSIN, 2011, p. 110). 
Federação das Organizações Indígenas do Rio Negro (FOIRN). Em Rio Branco, compuseram a equipe a coordenadora de campo da RPF, Dominique Aguiar, e Marcos de Almeida Matos, da Comissão Pró-Índio. A responsável pelas atividades foi Alcinda Lima, professora do Núcleo de Tecnologia Educacional do Governo do Estado de do Acre (NTE), Secretaria do Estado de Educação.

Na etapa seguinte à implantação da infraestrutura, a parte mais complicada, foi a vez da instalação dos equipamentos: três computadores em cada ponto, além de para-raios e painel solar (com peso de meia tonelada). A instalação aconteceu durante todo o mês de outubro em cinco pontos, em aldeias indígenas situadas em Roraima, Rondônia e Mato Grosso. Virginia Barbosa Gandres (coordenadora de campo), Dominique Aguiar (assessora de campo) e Alice Fortes (fotógrafa) acompanharam essa fase de instalação ${ }^{157}$. Todas as etapas foram fotografadas e as imagens estão disponíveis na secção "Galeria de fotos" do site.

Em abril de 2010 foram realizadas as oficinas de Formação em Audiovisual, seguidas da de Formação em Edição. Em São Gabriel da Cachoeira, as oficinas ocorreram entre julho e setembro de 2010, o último curso e etapa final do projeto de implantação dos trinta Pontos de Cultura Indígenas (PCls), momento importante de aprendizagem sobre como transmitir o material filmado para o computador e utilizar programas de edição de vídeo, assimilando, conjuntamente, o conceito de edição.

Encontrei no site da Agência de Comunicação do Estado do Acre um registro da expectativa dos jovens participantes desses trabalhos:

"Lá na aldeia a gente vai trabalhar com a história dos nossos antepassados, que não sabemos hoje, e vamos desenvolver na comunidade. Todos os jovens vão contar histórias para os filhos, quando tiverem", conta Alderico Yawanawá, da aldeia Nova Esperança, em Tarauacá. José Nilson Kaxinawá, da aldeia São Vicente, diz que vai utilizar o ponto de cultura para dar continuidade ao que vinha fazendo, como "gravação de CDs com cantorias do cipó $^{158}$ para o fortalecimento da cultura, trabalho audiovisual, pesquisa e publicação de material didático para professores".

Sueli Jaboti Kanoe veio da aldeia Ricardo Franco, em Guajará-Mirim (RO), e também pretende resgatar os costumes tradicionais através de cartilhas, CDs, danças e língua materna. "Estou achando ótima essa oficina. Valeu o esforço para estar aqui desenvolvendo e aprendendo coisas novas para levar à minha comunidade", afirma. "É importante valorizar esse trabalho porque são as identidades do povo indígena que ele vai fortalecer. Mostraremos o que é o povo

\footnotetext{
${ }^{157} \mathrm{O}$ restante dos kits já havia sido distribuído nos outros pontos da Rede.

$158 \mathrm{O}$ cipó, aqui, se refere à ayahuasca.
} 
indígena Suruí para a sociedade local, nacional e internacional", conta Gasodé Suruí, da aldeia Lapetanha. (Estado do Acre, 2009) ${ }^{159}$

Em cada turma, os participantes foram divididos em duplas para que pudessem trabalhar com um único material, de dez minutos aproximadamente, filmado por eles. Realizado pela equipe do Vídeos nas Aldeias ${ }^{160}$, em parceria com a Rede Povos da Floresta ${ }^{161}$, as primeiras oficinas aconteceram nas aldeias Kaxinawá e Yawanawá do Rio Jordão (Acre). Em seguida, na aldeia do povo Katukina, no Centro Yorenka Ãtame, na aldeia Apoena Meireles, em Rondolândia (MT) e em São Gabriel da Cachoeira (AM), cidade com $90 \%$ da sua população composta por indígenas pertencentes a 23 etnias, sobretudo Baniwa, Baré, Tukano e Desana. Todo o material produzido pelas oficinas foi encaminhado para Olinda (PE), sede do Vídeo nas Aldeias, para a finalização dos vídeos produzidos, realizada por Vincent Carelli. Esse material ainda não foi divulgado. No total, participaram da implantação dos PCls as seguintes etnias: Ashaninka, Baniwa, Baré, Jaboti, Jaminawa, Kontanawa, Katukina, Kaxinawá, Marubo, Nukini, Poyanawa, Tukano, Suruí, Yawanawá e Yanomami.

Em setembro de 2010, o Ministério da Cultura, representado pelo Ministro Juca Ferreira, e a Associação de Cultura e Meio Ambiente, representada por João Fortes, assinam, em Rio Branco, o convênio para a construção de um Centro de Saberes da Floresta no espaço do Yorenka Ãtame. Tal acordo foi noticiado pelo próprio MinC:

A meta é construir um espaço multiuso com auditório, estúdio de
gravação musical e sonorização, camarim, depósito para materiais e
um Teatro Arena. "Por uma questão de preservação da tradição
todas essas instalações serão desenvolvidas dentro do formato da
arquitetura dos Ashaninkas", observa João Augusto Fortes,
coordenador executivo do projeto. A infraestrutura, orçada em $\mathrm{R} \$ 4,7$
milhões, será implementada ao longo de três anos e vai permitir a

${ }^{159}$ Disponível em: http://www.agencia.ac.gov.br/index.php?option=com_content\&task=view\&id=9942\& Itemid=40. Acesso em: 10 nov. 2012.

${ }^{160}$ No Projeto Vídeo nas Aldeias, participaram das oficinas, como formadores: Ana Carvalho, Carolina Canguçu, Daniel Castelo Branco, Marcelo Pedroso, Pedro Portella, Julia Barreto e Camila Machado.

161 A equipe da Rede Povos da Floresta era formada pelas assessoras de campo: Deborah Castor, Dominique Aguiar e Mary Bastos; a coordenadora de campo Virginia Gandres e a fotógrafa Alice Fortes. Todos os materiais utilizados pelos formadores das oficinas vieram do Rio de Janeiro. Obviamente houve toda uma operação logística da RPF do Rio de Janeiro, formada por João Fortes, coordenador técnico, Cristina Reis, responsável pela coordenação de operação e integração, e Rita Aguiar, da equipe de apoio ao planejamento e logística. 
fomentação de projetos artísticos, cursos de formação em gestão de projetos culturais e na área de políticas públicas em diferentes módulos, além do fortalecimento da comunicação local. (MinC, $2010)^{162}$

Em outubro de 2010, ocorre, em Brasília, o Encontro entre os Pontos de Cultura Indígenas Associação Apiwtxa do Alto Rio Juruá e o Centro Cultural Yorenka Ãtame, e o ministro interino Alfredo Manevy para a apresentação da proposta de um Centro de Ciência dos Conhecimentos Tradicionais dos Povos da Floresta no Yorenka. Posteriormente, a ideia foi transformá-lo num Pontão, mas isso não se concretizou. Na visita que realizei em novembro de 2012 ao Centro encontrei uma estrutura inacabada, que deveria ter sido um grande auditório. Segundo Benki Pianko, as mudanças ocorridas no $\mathrm{MinC}^{163}$ no início do governo da presidente Dilma Rousseff dificultaram a continuidade. Ao mesmo tempo, mencionou os problemas na prestação de contas do convênio anterior, assinado pela Associação de Cultura e Meio Ambiente (a representante jurídica da RPF).

De qualquer forma, esse 'problema' se torna visível na falta de atualização do site. Em 2011, o registro de atividades Rede começa a arrefecer. São publicados somente cinco posts com notícias não associadas às ações da Rede. A vigência do convênio com os parceiros das organizações governamentais (MinC e FUNAI) foi até 10 de abril de $2011^{164}$. Alguns projetos não resistiram ao tempo, como o Nanapini, relativo à neutralização de emissões de carbono e de ações ambientais realizadas pelas comunidades da região amazônica (RPF, 2000). Lançado em 2009, o projeto

${ }^{162}$ Disponível em: http://www.cultura.gov.br/site/2010/08/30/centro-de-cultura-da-floresta/. Acesso em: 10 out. 2011.

${ }^{163}$ Na gestão da presidente Dilma Roussef, o Ministério da Cultura foi assumido por Ana de Hollanda (2011-2012), que não deu prosseguimento ao Programa Cultura Viva. Os Pontos de Cultura sofreram com os problemas de repasse de verbas e a desarticulação do apoio do MinC. Várias organizações e pessoas manifestaram desacordo com a gestão da ministra, que não deu continuidade às políticas de Cultura Digital iniciadas por Gilberto Gil (2003-2008) e prosseguidas por seu sucessor Juca Ferreira (2008-2010). Após sofrer enorme pressão durante seu mandato, vindo de intelectuais, gestores e vários setores da Cultura Brasileira, Ana de Hollanda pede demissão, assumindo em seu lugar Marta Suplicy, a partir de 11 de setembro de 2011.

164 Consta no site do Portal da Transparência o n. 640052 do convênio registrado no Sistema Integrado da Administração Financeira (SIAFI), com o seguinte objeto: "Contratar uma OSCIP para atuar em parceria com a FUNAI nas atividades de implantação, apoio, acompanhamento e gestão administrativa e financeira do Programa Mais Cultura - PCl, do Acordo FUNAl e MinC, tendo como público alvo as comunidades indígenas, suas associações e entidades de apoio, dos Estados do Acre, Amazônia". Concedente: Associação de Cultura e Ambiente. Valor do convênio: $\mathrm{R} \$ 6.479 .876,00$, sendo o valor liberado de $\mathrm{R} \$ 5.705 .116,00$. Início da vigência do convênio: 29/12/2010; fim da vigência: 10/04/2011. Consta como adimplente e em processo de "Tomada de Contas Especial". No jargão da Administração Pública, o convênio está suspenso e sob processo de ressarcimento no caso de eventuais prejuízos. 
ajudaria o financiar o reflorestamento na região, mas, por razões que não consegui descobrir, o projeto foi desativado. Como mencionei anteriormente, no site da Rede há um ícone inicial que remete ao site do projeto, atualmente fora do ar.

Em conversa com Ailton Krenak pelo Facebook ${ }^{165}$, ele afirmou que, com o encerramento do ciclo 2009-2010, as comunidades e os agentes culturais dos Pontos de Cultura estão avaliando suas atividades para a continuação dos trabalhos, mas também estão desenvolvendo "ações locais... desdobramento de seus 'projetos'... que se articulam com outros níveis de governança local, regional... outros parceiros..." (Krenak, entrevista via Facebook, 16/11/2012). Isto é, a partir da estrutura montada e da formação realizada com seus participantes na fase de implantação dos $\mathrm{PCl}$, numa lógica autopoietica e rizomática, os Pontos disseminados foram se desenvolvendo segundo seus contornos locais. Tal processo é condizente com a autonomia dessas comunidades e suas diferentes formas de se relacionar com as tecnologias de informação e comunicação.

A última notícia sobre as atividades da Rede na mídia foi na Conferência Rio+20, de 20 a 21 de junho de 2012. Ailton Krenak e Benki Pianko participaram dos debates no Seminário Culturas Indígenas na Rio+20, no Galpão Cidadania, onde também estavam representantes do MinC e de entidades com projetos desenvolvidos e apoiados pelo governo federal.

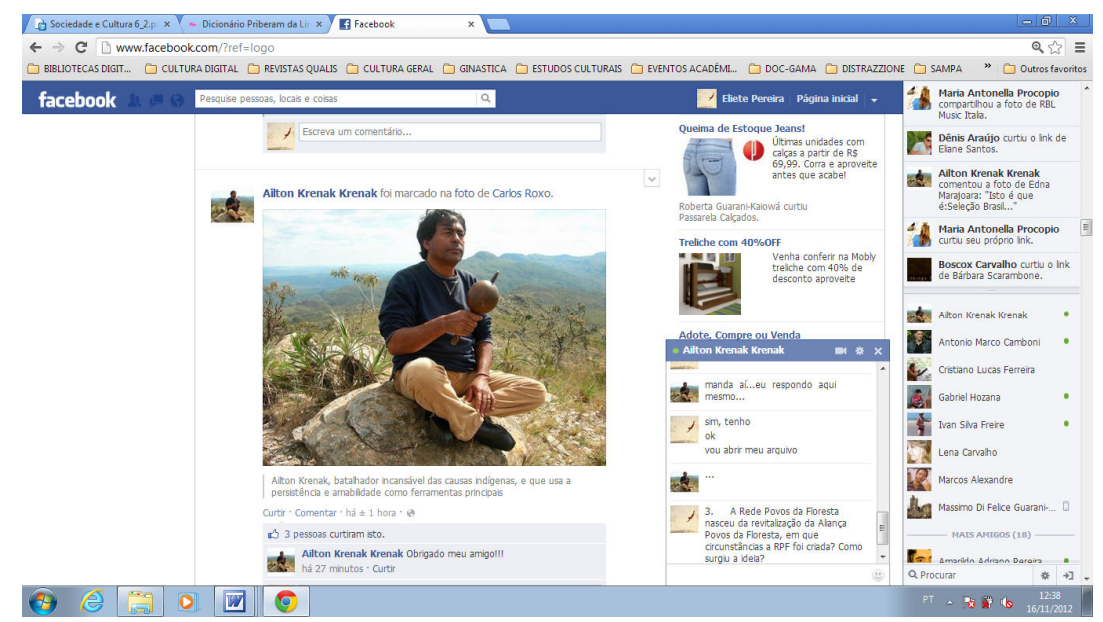

Figura 6 - Captura de tela conversa com Ailton Krenak (Facebook, 6/11/2012)

${ }^{165}$ A Rede Povos da Floresta não possui um grupo (oficial) no Facebook, mas um fã criou um em nome da Rede. Solicitei amizade a Ailton Krenak, que me aceitou em seguida. Nossa conversa se deu, sobretudo, nos dias 15 e 16 de novembro de 2012. Também tenho Benki Pianko e Gal Rocha como amigos no meu perfil. Infelizmente durante a pesquisa não consegui localizar João Fortes. Ele não tem perfil no Facebook, o que dificultou o contato. 
A capilaridade da RPF rendeu experiências locais muito próprias de interação com as tecnologias comunicativas em uma perspectiva reticular e ecossistêmica. Entre elas a dos Suruí (povo Paiter), da Terra Indígena Sete de Setembro, mencionado anteriormente e citado por Krenak durante nossa conversa, bem como a experiência realizada pelos Ashaninka do Amônia com o Centro Yorenka Ãtame. A Rede cumpre aquilo que é, sem comando, sem meio e sem fim. 
CAPÍTULO 4

\title{
O CENTRO YORENKA ÃTAME E A ECOLOGIA XAMÂNICA COMUNICATIVA ASHANINKA
}

\begin{abstract}
Eu: Por que essa ideia de fazer o Centro Yorenka Atame, um projeto mais amplo, não só voltado para o povo Ashaninka?

Benki Pianko: Cada empreendimento tem um fundamento, né, e cada fundamento tem uma abertura para aquilo que se pensa. Quando foi criado o Centro Yorenka Ãtame, ele veio no intuito de levar a mensagem do povo Ashaninka pra que não ficasse centralizado só naquilo que a gente vive na comunidade... porque temos vários projetos de manejo de floresta, de quelônio, fauna silvestre, temos o trabalho dos artesanatos, pesquisa de frutos e sementes na nossa comunidade, pesquisa de alimentos que o nosso povo come na floresta [...] tudo isso é uma riqueza muito imensa... E o entorno da nossa terra sendo invadido... pra nós era um problema... e pra esse problema se acabar, a gente tinha que entrar como um ponto de criar ali um impacto revertendo o que essas populações [de fora] estavam fazendo no nosso território... e o quê poderíamos fazer? Mostrar o que a gente sabe! Não tudo, mas pelo menos uma parte [...] Isso aqui [o Centro] pode dar uma visibilidade pra aquilo que a gente faz e ao mesmo tempo introduzir uma mensagem pro mundo [...] e a internet interligou tudo isso [...]. Então, o Centro foi pensado nesse nível, de poder trazer a nossa experiência e colocar pra sociedade de Marechal Thaumaturgo que tanto falava:

"pra quê índio com terra?" "pra quê índios com terra desse do tamanho? Que nem sabe trabalhar, nem sabe

fazer nada...." Então a gente está mostrando que a nossa diferença não é só a cultura... a nossa diferença é como viver consorciado com essa diversidade e ter ela como uma parte de nossa vida e que essa vida é parte de todo mundo... ${ }^{166}$
\end{abstract}

Neste capítulo apresento a análise do polo de irradiação da Rede Povos da Floresta, o Centro Yorenka Ãtame, resultado da política ecológica xamânica e comunicativa dos Ashaninka da aldeia Apiwtxa do Rio Amônia. Busquei, assim, descrever essa rede, composta de atores humanos e não humanos, mostrando

${ }^{166}$ Entrevista com Benki Pianko realizada no Centro Yorenka Ãtame (Marechal Thaumaturgo - Acre) em $1^{\circ}$ de dezembro de 2012. 
porque esse Centro e a atuação dos Ashaninka se destacam dentro dessa ação comunicativa reticular. Versando uma compreensão mais aprofundada, recorro às especificidades históricas e culturais do povo Ashaninka, mostrando, por meio dessa análise histórica, a forma como a reatualização dos seus sistemas de trocas tradicionais, dentro de um contexto de digitalização - de acesso à Internet e aos diversos dispositivos técnicos comunicativos (computadores, celulares, etc.) -, empreendem modos criativos e inovadores de interação deles com seus territórios, estendendo o ecossistema natural a uma dimensão tecnoinformativa. Em seguida, discorro sobre as arquiteturas informativas deles, principalmente o blog da aldeia Apiwtxa e o blog "Saberes da Floresta", do Centro Yorenka Ãtame. Na última parte, encerro com a interpretação do significado dessa digitalização, referindo-me à tríade simbiôntica, caracterizada, nesse caso, pela extensão da cultura e do território dos Ashaninka nas redes digitais.

Após analisar todos os posts do site da RPF, percebi que o conteúdo disponível no site foi produzido por uma equipe de comunicação, principalmente pela jornalista Gal Rocha. Nenhum post foi assinado pelos Ashaninka, embora eles fossem a referência constante e suas vozes estivessem presentes. Dos povos da floresta participantes da Rede, eles eram os que participaram direta e ativamente do desenvolvimento dela, seja nas rodas de conversa para o planejamento estratégico de implantação dos PCl's, seja no encontro com os representantes de organizações governamentais e não governamentais. Tal participação é condizente, como veremos neste capítulo, com sua cosmologia xamânica e sua política interétnica.

Os posts do site da Rede Povos da Floresta representam a polifonia de vozes desses fluxos informativos hipertextuais, mostrando-nos simultaneamente suas relações com seus contextos simbólicos, territoriais, políticos, humanos, não humanos, independentemente da autoria dos textos. Indica, portanto, a heteroglossia e a dialogia no sentido dado por Bakthin, definido como um processo intersubjetivo de comunicação em que esse espaço de enunciação é multivocal, em que múltiplas perspectivas, vozes sociais e históricas estão presentes. $\mathrm{Na}$ concepção da cultura Ashaninka e na arquitetura da biodiversidade da Floresta, a contaminação, a polifonia, e a heteroglossia são realidades constitutivas da complexidade do habitar ecossistêmico (cf. VIVEIROS DE CASTROS, 2006). No caso do site da Rede Povos da Floresta, a multiplicidade de vozes e contextos sociais estava presente nos hipertextos, nas imagens, nos vídeos com os quais eu 
mesma, silenciosamente, interagi por meio das interfaces e das linguagens midiáticas dos tecno-atores plurais da Rede. Estes, no decorrer da pesquisa, me possibilitaram habitar em suas espacialidades e temporalidades comunicativas.

Portanto, nos posts da RPF, embora não sejam de autoria dos Ashaninka, estão presentes as "reverberações dialógicas" de suas vozes e de suas perspectivas sobre o processo de digitalização em curso. Assim, as vozes dos participantes deixaram seu rastro, seja discursivo, imagético ou audiovisual, expressões da dimensão de um ecossistema informativo complexo.

Como vimos anteriormente, dos grupos articuladores e ativos da Rede, representados pelas figuras de Ailton Krenak, João Fortes e Benki Pianko, os Ashaninka, seja através do próprio Benki e/ou de seu irmão Moisés Pianko, se destacam pelo nível de engajamento, articulação e presença em sua própria comunidade e seu reconhecido prestígio dentro e fora dela. Essa "supremacia" Ashaninka na RPF deve-se, assim, às especificidades da comunidade Apiwtxa do Rio Amônia, e da família Pianko, de como eles conseguiram reverter para si o contato com os brancos, reinterpretando seus "recursos cosmológicos" (LESSIN, 2011), tornando-se os enunciadores do desenvolvimento sustentável local a partir da lógica de desenvolvimento de "projetos" (PIMENTA, 2002), em que se considera também os agentes não humanos desse ecossistema.

\subsection{COSMOLOGIA E HISTÓRIA DA POLÍTICA INTERÉTNICA ASHANINKA DO AMÔNIA}

Para explicar brevemente os meandros dessa cosmologia e da história da política interétnica Ashaninka do rio Amônia me apoiei, sobretudo, nos trabalhos dos antropólogos Pimenta (2002, 2007), Mendes (2002) e Lessin (2011), e também na obra de Eduardo Viveiros de Castro. Embora este antropólogo não tenha etnografado os Ashaninka, refiro-me ao seu trabalho sobre o perspectivo ameríndio partindo das cosmologias amazônicas, baseado no xamanismo, para tecer alguns comentários à repeito da cosmologia xamânica Ashaninka ${ }^{167}$.

${ }^{167} \mathrm{O}$ trabalho de Viveiros de Castro é uma referência importante sobre o assunto, no qual Lessin (2011) também se apoiou em seu trabalho, citado em alguns momentos desta tese. 
A tese de José Pimenta ${ }^{168}$ analisou a história da política interétnica Ashaninka no contexto regional, enfatizando justamente as adaptações, negociações e reelaborações da política de afirmação e resistência da cultura Ashaninka. Ao longo do contato com o branco, durante a demarcação de suas terras, em 1992, até os últimos anos que antecederam sua pesquisa, cuja tese foi publicada em 2002, Pimenta analisa as novas estratégias Ashaninka de organização social e política e sua resistência cultural diante do contato com o branco. Entre essas novas estratégias, a organização de associações e cooperativas e a elaboração de projetos voltados para o desenvolvimento sustentável apontam para a ampliação de novas alianças, segundo o arbítrio cultural do grupo.

Margarete Kitaka Mendes $(1991,2002)$ fez a primeira etnografia com os Ashaninka do Amônia, priorizando o estudo do ritual do piyaretsi ${ }^{169}$, atribuindo sua importância para a vida política da Aldeia. Sua pesquisa reuniu também dados mais gerais, os quais ela publicou no capítulo destinado aos Ashaninka na Enciclopédia da Floresta, organizada pelos antropólogos Manuela Carneiro da Cunha e Mauro Barbosa de Almeida (2002).

Leonardo Lessin (2011) focalizou, em sua tese, o êxito histórico político da Apiwtxa a partir da sua perspectiva cosmológica acerca do desenvolvimento e da sustentabilidade socioambiental. Sua tese lança luz ao "perspectivismo Ashaninka", a uma dimensão xamânica desse grupo.

Em um território [xamânico] surpreendente, em que a diversidade natural reflete uma multiplicidade de formas políticas de relação entre praticamente todos os seres, a sustentabilidade, o desenvolvimento e o equilíbrio ambiental são pensados e produzidos, pelos Ashaninka da Apiwtxa, através de uma estruturação xamânica própria. (LESSIN, 2011, p. 13)

${ }^{168} \mathrm{O}$ antropólogo pesquisou os Ashaninka do Rio Amônia, realizando trabalho de campo na aldeia Apiwtxa durante sete meses no ano de 2000. Produziu a tese sobre a história da política interétnica Ashaninka no contexto regional. Para a composição deste capítulo, analiso os seguintes trabalhos do antropólogo: Índio não é todo igual: a construção Ashaninka da história e da política interétnica (2002) e "Indigenismo e ambientalismo na Amazônia ocidental: a propósito dos Ashaninka do rio Amônia” (2007).

169 O nome piyaretsi denomina tanto a bebida fermentada de mandioca, feita pelas mulheres Ashaninka, como o ritual onde ela é consumida. Para os Ashaninka, esse é um momento de homenagear Pawa, o Deus criador de toda forma de vida, e de falar sobre os assuntos da aldeia, das famílias, da vida em geral. O consumo dessa bebida é comum entre vários povos indígenas da Amazônia peruana e do Acre, e entre os brancos da região do Alto Juruá, que a chamam de caiçuma. No Peru, ela é chamada de masato. Existe, ainda, em outras regiões da Amazônia brasileira com o nome de caxiri (PIMENTA, 2002, p. 6). 
Durante a análise das arquiteturas informativas e após as entrevistas realizadas com Benki Pianko, entre outros, ficou bastante evidente que os modos pelos quais eles interagem com as linguagens midiáticas digitais são indicativas de um processo particular de digitalização de uma comunidade indígena brasileira, dadas as especificidades de seus aspectos socioculturais e territoriais. Tal processo está largamente associado à sua política interétnica e à sua cosmologia xamânica, que reinterpreto como expressão de um tipo de ecologia política (LATOUR, 2004) por estar associada aos coletivos humanos e não humanos, portanto, a um modo diferenciado de pensar a relação Natureza e Sociedade. Igualmente, considero essa cosmologia xamânica como um tipo de cosmopolítica, no termo de Isabelle Stengers (2005), de 'cosmo' no sentido grego de mundo, política do cosmo. "Para Stengers, o cosmos é o desconhecido possível construído por entidades múltiplas e diversas. Cheio da promessa de articulações que seres diversos podem eventualmente fazer, o cosmos é o oposto de um lugar de paz transcendente" (HARAWAY, 2011, p. 46).

A cosmopolítica dos povos indígenas baseia-se em formas particulares de percepção e relação com a "Natureza", que imprime significados diferenciados entre as categorias de "Cultura" e "Sociedade" dos elaborados pelo pensamento Ocidental. O xamanismo ameríndio detém um tipo de habilidade transitiva graças ao modo de pensar a humanidade como característica ontológica estendida, onde é a Natureza a sofrer as variações, sendo chamado pelo antropólogo Eduardo Viveiros de Castro (2006, p. 358) de multinaturalismo: "Se o multiculturalismo' ocidental é o relativismo como política pública, o perspectivismo xamânico ameríndio é o multinaturalismo como política cósmica".

Viveiros de Castro procura significar o perspectivismo ameríndio, ou o ponto de vista indígena, como posição pronominal tomada diante da variedade corporal dos animais, das plantas e dos humanos, "várias" naturezas numa só "cultura" ${ }^{170}$. Isto é, o ponto de vista é uma posição do sujeito, seja humano e/ou animal, tomada por uma referência corporal. Essa compreensão de corpo evoca uma diferença de perspectiva entre humanos e animais que não é só fisiológica, mas fundamenta-se, sobretudo, nas maneiras e modos de ser.

Essa perspectiva do sujeito, marcada pela "descontinuidade" corporal presente nas cosmologias amazônicas, aponta também para um sentido de

\footnotetext{
${ }^{170}$ Ver Viveiros de Castro (1996).
} 
"continuidade" complementar ao considerar uma única "humanidade,171 entre humanos e animais. Consequentemente, essa concepção "humana" é diferente daquela historicamente elaborada pelo pensamento Ocidental porque não é uma caracterítica exclusivamente dos "humanos", é uma condição também dos "nãohumanos" (animais e plantas). A distinção corporal marcadora por diferentes perspectivas só é transcendida pelos xamãs e pelas narrativas míticas ${ }^{172}$, que remetem a um tempo em que havia uma permeabilidade entre mundos humanos e não humanos.

No caso especificamente dos Ashaninka do rio Amônia, sua cosmologia é baseada em uma forte contraposição entre o Bem e o Mal, estruturada em um universo reticular composto de camadas superpostas. O subterrâneo (isawiki) está associado à kamari, os espíritos do mal (geralmente os brancos são associados a eles ${ }^{173}$ ). Nos relatos realizados por Gerald Weiss (1969), o céu (henoki) detém várias camadas. Lá está presente, no topo (inkite), Pawa, Deus todo-poderoso, criador de todo o universo. Na camada inferior estão os Tasorentsi, entidades divinas: "eles são como um Deus, pegam qualquer coisa, sopram e transformam em outra coisa" (ISA, 2012). Abaixo deles, os bons espíritos, Tasorentsi, são os "verdadeiros filhos de Deus". Nessa camada Pawa seleciona, entre os Ashaninka, quem são seus filhos:

A criação do mundo feita por Pawa foi direta e indiretamente apoiada pelos seus filhos. Pawa criou a terra, a floresta, os rios, os animais, os homens, o céu, as estrelas o vento, a chuva... Na mitologia nativa, muitas dessas criações são, na realidade, transformações de pessoas ashaninka, filhos de Pawa, em outra coisa e foram

${ }^{171}$ Para Viveiros de Castro a humanidade, no sentido apresentado pelas cosmologias ameríndias, é uma condição comum entre humanos e não humanos. Dessa forma, "os animais são humanos porque são sujeitos (potenciais)" (2002, p. 374), e a humanidade é "o nome da forma geral do Sujeito" (2002, p. 374).

${ }^{172}$ Nas sociedades ameríndias, o mito é uma referencial temporal, um esquema lógico e conceitual, integrado na ordem simbólica e prática das sociedades que dele compartilha (LEVI-STRAUSS, 1970; VIVEIROS DE CASTRO, 2006).

173 Os Ashaninka chamam os brancos de "wirakotxa" que se relaciona ao personagem mítico Inka: "O Inka foi responsável não só pelo surgimento do homem branco no mundo terrestre [pescado por Inka no lago], [...], mas também ofereceu ao branco todo o poder que Pawa tinha deixado originamente para os Ashaninka. Os informantes explicam que o Deus-criador era todo-poderoso e detinha todos os conhecimentos. Seu filho Inka foi encarregado de transmitir toda essa força e sabedoria aos Ashaninka, mas, após provocar a chegada dos brancos, o Inka também os beneficiou com esse conhecimento. [...]. Alguns informantes explicam que os brancos capturam o herói e o mantém cativo até hoje em detrimento do povo Ashaninka. Outros relatos contam que o filho de Pawa não está preso, mas esqueceu-se do seu povo e prefere viver com os wirakotxa. [...] Forçado ou não, em ambos os casos, o Inka ensinou tudo aos brancos. Dessa forma, para os Ashaninka, a superioridade tecnológica e econômica do mundo ocidental é vista como um roubo de um conhecimento originalmente destinados aos índios." (PIMENTA, 2002, p. 359). 
realizadas através do sopro. Assim, nos tempos da criação do mundo, os animais, as plantas, os astros ou certos lugares ou fenômenos tinham uma aparência humana e eram, de uma maneira geral, filhos de Pawa. Em função do comportamento desses primeiros Ashaninka na Terra, o Deus e/ou os Tasorentsi transformaram-nos em outra coisa, ruim ou boa. (PIMENTA, 2005) ${ }^{174}$

Essa estruturação cosmológica dicotômica serve de modus operandi de classificação dos diferentes tipos de espíritos e da humanidade. O xamã guia as atividades espirituais pelo uso do kamãrapi (Ayahuasca), permitindo sua comunicação com os seres invisíveis que povoam o universo. Vale lembrar que para os Ashaninka o xamã está em contínua formação, está sempre aprendendo.

Para melhor compreensão dessa perspectiva xamânica Ashaninka, apresento alguns dados específicos sobre esse grupo indígena. Ashaninka é uma autodeterminação desse povo pré-andino de língua Arawak, cujo significado é "gente de verdade". As populações regionais também os chamam de "Kampa", termo presente, ademais, nos documentos coloniais. Totalizam mais de 90.000 pessoas presentes no Peru (INEI, 2007) e no Brasil, sendo que 1.200 estão em terras brasileiras (Siasi/Sesai, 2012), divididos em cinco Terras Indígenas distintas e descontínuas situadas na região do Alto Juruá. T. I. Jaminawá/Envira (município de Feijó); T. I. Kampa do Rio Envira (município de Feijó); T. I. Kampa do Igarapé Primavera (município de Tarauacá); T. I. Kaxinawá do Rio Breu (município de Marechal Thaumaturgo); T. I. Kampa do Rio Amônia ${ }^{175}$ (município de Marechal Thaumaturgo). Como vimos anteriormente, os membros dessa última comunidade participaram ativamente da construção da Rede Povos da Floresta.

Situados na fronteira do Brasil com o Peru, com a Reserva Extrativista do Alto Juruá $^{176}$, com o Parque Nacional da Serra do Divisor e de um assentamento do INCRA, todos situados no município de Marechal Thaumaturgo (AC), os Ashaninka do Amônia são aproximadamente 450 pessoas divididas em grupos familiares. "Em geral, uma a seis famílias ligadas por grupos de parentesco, formando os grupos locais. Cada núcleo familiar possui seus roçados e independente do ponto de vista e econômico, o que não exclui relações marcadas por intensa reciprocidade entre as unidades" (MENDES, 2002, p. 162).

\footnotetext{
174 Informação disponível no site do Instituto Socioambiental: http://pib.socioambiental.org/pt/povo/ ashaninka/147 Acesso em: 13 nov. 2012.

175 Terra Indígena Kampa do Rio Amônia foi homologada com 87.205 hectares.

176 Criada em 1990, foi a primeira Reserva Extrativista do Brasil decorrente da luta histórica dos seringueiros.
} 


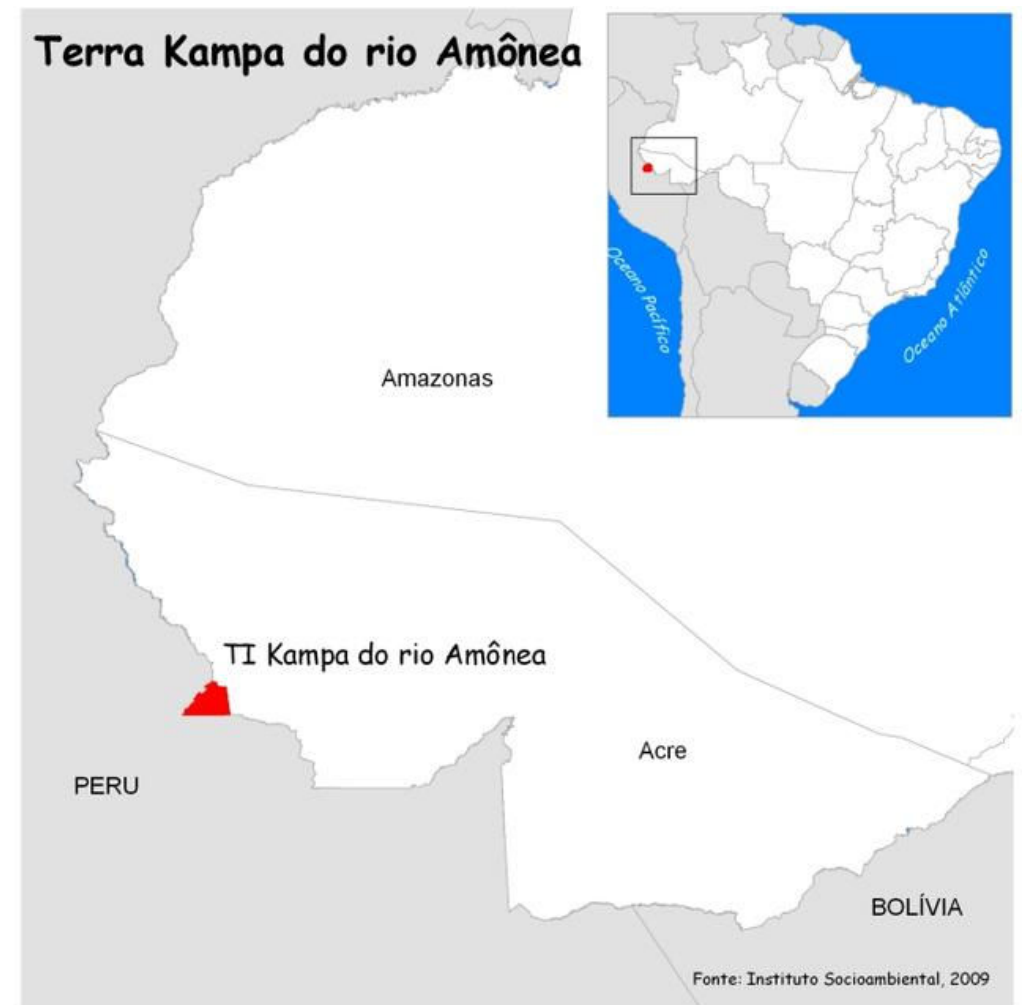

Figura 7 - Mapa da Terra Indígena do Kampa rio Amônea (ou Amônia) Ashaninka

Essas famílias vieram do Peru pressionadas pelos caucheiros ${ }^{177}$ peruanos, no final do século XIX. Ao contrário dos Ashaninka do Peru, os do Brasil nunca se "integraram completamente na economia extrativista da borracha, preferindo sempre outras atividades comerciais ao trabalho no seringal" (PIMENTA, 2002, p. 5). Eram vistos como "povos guerreiros", "determinados" e "violentos" desde os tempos dos Inkas, cujo conflito os conduziu cada vez mais para a floresta. Caracterizados, do ponto de vista ecológico, como "ribeirinhos" (da classificação de grupos "montanheses" e "ribeirinhos"), as famílias Ashaninka do Amônia se estabeleceram na região por volta de 1940, vindos do rio Tambo e de igarapés próximos ao rio

\footnotetext{
177 Aqueles que extraíam o látex do caucho. A diferença do caucho e da seringa ocorre nos modos diferenciados de extração do látex para a produção da borracha. No caso da árvore do caucho, ela é cortada em anéis para a extração do látex; a seringueira, ao contrário, tem produção contínua, sem a necessidade de sua derrubada.
} 
Ucayali. Vivem principalmente do cultivo da mandioca, da caça ${ }^{178}$ e da pesca e da venda do artesanato, sua principal fonte de renda ${ }^{179}$ (MENDES, 2002).

As diversas famílias, organizadas em grupos locais, vivem espalhadas pela floresta ao longo das margens dos rios. Cada grupo local forma uma unidade política definida e estável em torno do homem mais velho, de prestígio, capaz de arregimentar uma extensa parentela:

O prestígio de um homem ashaninka, que outrora estava relacionado com suas qualidades de guerreiro, hoje concentra-se em sua capacidade de trabalho, demonstrada basicamente por seu talento como caçador e pelo tamanho de seus roçados; é essencial também sua capacidade de tecer alianças com o exterior, a fim de garantir 0 acesso regular a produtos manufaturados. (MENDES, 2002, p. 162)

Antonio Pianko, pai de Benki, constitui hoje o que eles chamam de kuraka ${ }^{180}$ (palavra de origem quéchua) e reúne todos esses atributos. Filho do mítico Samuel Pianko, grande chefe (kuraka), e poderoso xamã (sherepiari) do primeiro agrupamento maior (namptsi ${ }^{181}$ ) do Amônia. Grande conhecedor da Ayahuasca (Kamarampi ou Kamarampe) e de outras ervas medicinais tradicionais, Samuel era uma importante liderança local reconhecida para além do território Ashaninka. Após sua morte, esse grande namptsi dispersou-se, vindo a se reunir posteriormente, mas em menor número, em torno de seu filho Antonio Pianko. O casamento interétnico de Antonio com "D. Piti", filha de seringueiros, o fortaleceu dentro da política Ashaninka de valorização de alianças, qualificando-o para assumir o papel de seu pai. De fato, além de ser um exímio caçador, conhecedor dos costumes dos animais

${ }^{178}$ A caça para os Ashaninka fundamenta-se na forma como esse grupo se relaciona com seu território e sua cultura. Um homem Ashaninka se distingue na Aldeia por ser um bom caçador e comunicador, ou seja, aquele que sabe andar na mata e que se relaciona com os espíritos que ali estão.

179 Os Ashaninka possuem seus roçados para subsistência, mas, com a venda de artesanato, conseguem comprar outros produtos dos quais não dispõem (sal, panelas, terçado, miçangas, etc.). O artesanato deles compreende: kusmas (vestido tradicional de algodão feito no tear pelas mulheres), bolsas, caixas de palha de murmuru, colares, chapéus, pulseiras de miçangas.

180 Embora os grupos locais se agrupem sob a influência de um homem mais velho, formando em torno dele o que os Ashaninka chamam de nampitsi ('território político', segundo Mendes, 2001), a instituição "chefia" não é uma instituição obrigatória entre eles. O termo "chefia", largamente utilizado pelos antropólogos, induz a um erro epistêmico ao buscar caracterizar essas organizações sociopolíticas indígenas sob a categoria do "chefe", nascida num contexto político ocidental.

181 Namptsi, na língua Ashaninka, foi interpretado por Mendes (1991) por "território político" Ashaninka. 
e da ciência das plantas, sua posição como kuraca se fortaleceu com o passar dos anos.

Embora tenham sempre vivido em unidades políticas relacionadas a um determinado local, por seus relatos orais e pelas referências dos brancos regionais se pode perceber que os Ashaninka são povos viajantes (povos de arribação, como a população local os define) motivados, sobretudo, por suas trocas tradicionais, 0 ayonpari ou ayonpare. É a partir desse sistema tradicional de troca que a comunicação entre territórios distantes "estabelece-se por meio de relações comerciais formalizadas que associam parceiros de troca, os ayopari" (MENDES, 2002, p. 162). Elos de parentesco em unidades politicas diferentes também motivam as viagens para as trocas.

A vinda para a região do rio Amônia foi motivada para se fazer ayonpari com o Brasil: "[o Brasil] concebido como uma pessoa coletiva que representa uma afinidade potencial e que deverá permitir a troca e a obtenção de produtos diferenciados. Por outro lado, está presente a ideia de que o Brasil foi até a eles como um sujeito" (LESSING, 2011, p. 52). Essa concepção territorial deslocativa na perspectiva Ashaninka, delineada pelo ayonpari diante da vinda dos brancos, do "Brasil", reinscreve esse sistema de troca como uma condição de manutenção de sua autonomia política e cultural.

Portanto, essa predisposição às deslocações e às trocas, uma configuração tradicional reticular "mercuriana" para a comunicação, lhes deu a capacidade de exercer uma diplomacia política voltada para a própria autonomia política e cultural. Nas palavras de Leonardo Lessin (2011, p. 53), a "estrutura tradicional reticular flexível" Ashaninka lhes proporcionou essa resistência cultural frente ao contato com o branco:

Tudo nos indica que a tradição guerreira e diplomática ancestral possibilitou à estrutura Ashaninka um agenciamento múltiplo de arranjos e permutações institucionais que astuciosamente produziu e sustentou sua autonomia política e cultural como nativos. Certamente, esta sustentabilidade teve origem na concepção de uma sociedade organizada para a reconquista da autonomia política. Em um complexo mitológico ritualístico voltado à produção de pessoas, é a inflexão da afinidade potencial que sustenta a força xamânica diplomática. No decorrer do processo de interação histórica com o ocidente, os Ashaninka se serviram de sua estrutura tradicional reticular flexível (que, a nosso ver, assegura, ainda hoje, uma 
capacidade incomum de rearranjo e resistência cultural, econômica e política do grupo) e, assim, garantiram sua autonomia.

Lessin refere-se a esse "complexo ritualístico voltado à produção de pessoas", ao ritual ${ }^{182}$ do piyaretsi - uso da bebida fermentada da madioca, pelo qual reforçam seus laços políticos e culturais entre os pares - e ao ritual do kamparampi (Ayahuasca), capaz de romper o tempo histórico para o ingresso ao tempo mítico de uma humanidade irrestrita ${ }^{183}$. Concebe ambos rituais como "produção de pessoas" (VIVEIROS DE CASTROS, 2006 apud LESSIN, 2011), afinidades potenciais de trocas.

Dentro do processo de história do contato ${ }^{184}$ com o branco, os Ashaninka não se transformaram em trabalhadores dos patrões seringalistas. Contudo, mesmo que não tenham se envolvido completamente na produção da borracha, muitas famílias Ashaninka trabalharam na extração da madeira para terem acesso aos produtos que não possuíam, principalmente terçado, sal, panelas, entre outros. Suas relações com o sistema madereiro eram complexas e em algumas situações trouxeram desagregação cultural e morte.

Esse período, caracterizado na memória dos velhos como o "tempo da madeira", entre os anos 1970 e 1980 caracterizou-se pelo contágio de doenças,

${ }^{182}$ Referimo-nos ao rito como ação que se repete segundo regras invariáveis, cujo ato não se esgota por sua eficácia, causa ou efeitos. Os rituais dizem respeito ao desenvolvimento do rito. No caso das populações ameríndias da Amazônia, os rituais presentificam o 'tempo mitíco' das suas cosmologias, como nos explica Lessin (2011, p. 20-21): "Serão as técnicas rituais que permitirão à humanidade terrestre se reencontrar periodicamente como humanidade mítica e reviver o instante cosmogônico da criação. Por meio de rituais, especialmente os rituais xamânicos, a comunidade pode vivenciar a passagem revitalizante do finito temporal ordinário e histórico para a duração infinita do Tempo sagrado. O Tempo sagrado, pela sua própria natureza mítica, é reversível, ou seja, é o Tempo mítico tornado presente pela experiência ritual".

${ }^{183}$ Vale reforçar o significado da Ayahuasca (kamparampi) para a cosmologia xamânica amazônica, bem como Ashaninka, neste excerto de Lessin (2011, p. 113): "Para se pensar a política e a economia externa Ashaninka é necessário levar em conta o mundo espiritual como parte integrante do Cosmos indígena. O complexo político econômico Ashaninka é uma trama de relações políticas xamânicas corporais e espirituais, físicas e metafísicas, internas e externas. [...] a ayahuasca é o pilar (Axis Mundi) do conhecimento xamânico amazônico; obviamente, a solidariedade mística entre a humanidade e o restante das formas naturais de vida na Amazônia indígena, passa pela amplitude da experiência extática obtida pela ingestão ritual da bebida. [...] 0 êxtase xamânico é, sobretudo, uma experiência de morte e ressurreição do xamã, e essa morte ritual é o signo do transbordamento da condição humana histórica à condição mítica transhistórica."

184 Como breve contextualização da "história" Ashaninka consideramos a história do contato com os brancos, narrada nos trabalhos de Pimenta $(2002,2007)$ e Mendes (2002), e o "tempo mítico" Ashaninka, citado por Lessin (2011). Obviamente, o tempo histórico é uma construção ocidental modulada por "fatos históricos" que, na história do contato, primou por inserir os Ashaninka em uma temporalidade do desenvolivmento amazônico nacional. No "tempo mítico" tem-se uma perspectiva Ashaninka intrinsecamente relacionada ao seu universo mítico, reatualizado em seus rituais e narrativas. 
exploração das mulheres pelos brancos e uso da cachaça, segundo eles trazida pelos brancos nos rituais do piyarentsi, além de ter sido um período escasso de caça por causa das derrubadas. A alteração do meio ambiente também mudou o modo de vida nativo (PIMENTA, 2007).

O mogno e o cedro são madeiras importantes na vida cotidiana dos Ashaninka. Eles coletam, por exemplo, vários tipos de sementes e de corantes vegetais destinados, principalmente, à fabricação de seu artesanato. Entre esses corantes, a casca do mogno é tradicionalmente usada no tingimento dos tecidos, em especial das kushma, sendo, portanto, um valioso recurso natural. De modo semelhante, o cedro, utilizado pelos Ashaninka na fabricação de canoas e de instrumentos musicais (tambores), tornou-se uma espécie rara. $O$ barulho causado pelas motosserras e outras máquinas usadas na atividade madeireira em grande escala, com equipes trabalhando, às vezes, dia e noite, afugentou muitos animais da área. $O$ óleo diesel derramado nos igarapés poluiu as águas causando a rarefação de peixes. (PIMENTA, 2007, p. 646)

Contudo, como não tinham um "patrão exclusivo" eles, de alguma forma, possuíam a liberdade de conduzir essas relações e souberam explorar as rivalidades entre os brancos, dentro da perspectiva nativa do ayonpari (PIMENTA, 2007).

Nessa conjuntura do "tempo da madeira", de grande crise, os Ashaninka souberam reconduzir suas ações e realizar importantes alianças, que culminaram com a demarcação de suas terras:

Se o "tempo da madeira" é hoje lembrado como um período de grandes dificuldades e de muitas inquietudes, os Ashaninka também ressaltam que foi em decorrência dessa conjuntura que eles começaram a se organizar para conquistar seus direitos. Foram as conseqüências da exploração madeireira em grande escala que levaram os índios a se mobilizar e lutar contra o domínio dos posseiros e dos patrões. Assim, a situação de crise social e cultural causada pela intensificação da exploração madeireira constitui o cenário do qual emerge uma nova tomada de consciência política por parte dos Ashaninka. Esse processo é caracterizado pela luta para a demarcação da terra indígena, momento decisivo em sua história recente. Nesse contexto de crise, os Ashaninka receberam o apoio de diversos setores do indigenismo e do ambientalismo. (PIMENTA, 2007, p. 647-648)

É nesse período que a categoria nativa de troca (ayonpari) será reconduzida para o desenvolvimento de projetos sustentáveis. Esse envolvimento dos Ashaninka 
do Amônia com os projetos sustentáveis começa na Aliança dos Povos da Floresta e, principalmente, na criação da cooperativa (1987) e da associação Ashaninka Apiwtxa ("Todos juntos" em Ashaninka) do rio Amônia, no início da década de 1990. Desde 1985 havia começado o processo de desocupação de posseiros na região para a demarcação de suas terras pela FUNAI, que culminou com a homologação, em 23 de novembro de 1992, iniciando-se, assim, o "tempo dos direitos" na memória deles. Embora homologadas, suas terras eram constantemente invadidas por caçadores e exploradores de madeira. Para resolver esse problema, os Ashaninka decidem ocupar a entrada da Terra Indígena do Kampa para, assim, controlar as invasões. As famílias passaram a se revezar no trabalho de fiscalização. Entretanto, isso não foi suficiente. No decorrer de 1995, Antonio Pianko, com outras famílias, decide ocupar a atual localização da aldeia Apiwtxa, local onde começa a jusante do rio Amônia. Tal mudança foi o primeiro grande desafio da associação Apiwtxa ao organizar o transporte de todos os objetos das famílias e ao reconstruir suas casas e roçados. Contudo, deixou saldos positivos, segundo Mendes (2002), pois facilitou os trabalhos da associação, a instalação de uma escola ashaninka e o controle do ingresso de pessoas estranhas passou a ser realizado de forma mais sistemática.

A reatualização do ayonpari estava nitidamente associada à capacidade deles de construir redes de apoio, um modo de capital social extendido para além de seus territórios. Essa forma reticular de agregar e manter apoios deu-se conjuntamente pela ampliação de suas "andanças", de suas viagens para fora de seu território e da "midiatização" de seus direitos, portanto, de suas existências. Tudo isso foi visível, sobretudo, antes e durante a demarcação de suas terras, visto que pessoas e instituições compuseram os 'nós' e as 'conexões' fundamentais: a antropóloga Margarete $\mathrm{H}$. Mendes ${ }^{185}$ os assessorou nos assuntos relacionados à demarcação de suas terras, à cooperativa, à associação e à escola (CUNHA e ALMEIDA, 2002, p.

${ }^{185}$ Margarete Mendes teve um papel importante em assessorá-los no redirecionamento dos trabalhos da cooperativa para a venda de artesanato. Até então, os Ashaninkas estavam buscando alternativas econômicas para a aquisição de produtos que não produziam. Chegaram a plantar milho, feijão e arroz, criando um excedente para a venda, mas esbarraram no boicote dos comerciantes de Marechal Thaumaturgo e Cruzeiro do Sul. Perderam quase toda a produção, aproximadamente nove toneladas. Além de terem derrubado parte de suas terras para a produção, viram que essa atividade era inviável. Mendes, no período em que fazia a sua pesquisa sobre o piyarentsi (1990), os ajudou no redirecionamento dessa atividade, incentivando-os a comercializarem o artesanato produzido por eles: as kusmas (roupas tradicionais de algodão feitas de tear), os chapéus, as bolsas e as caixas (de palha de murmuru), etc. Todos os produtos eram muito apreciados no comércio ecossustentável. Os primeiros produtos foram comercializados numa loja em São Paulo. Desde então o artesanato se tornou o principal recurso da cooperativa (PIMENTA, 2007) 
687); o antropólogo Terri Vale de Aquino e o indigenista Antonio Luis Batista de Macedos, os txais Terri e Macedo (ambos da Comissão Pró-Indio do Acre e da FUNAI), em diferentes proporções, ajudaram a ecoar as vozes dos Ashaninka do rio Amônia. Foi no jornal O Varadouro, de Cruzeiro do Sul (Acre), entre 1975 e 1980, que Terri sensibilizou e alertou a opinião pública sobre a situação dos índios e das populações seringueiras da região com a exploração da madeira pelos fazendeiros "paulistas". Não por acaso eles sofreram vários ataques contra suas vidas (PIMENTA, 2007).

Dentro dessa lógica de alianças e apoios, com a ajuda de Macedo, em 1986, os Ashaninka começaram a sair do Amônia para reivindicar seus direitos em Cruzeiro do Sul e em Rio Branco. Nesse momento, inauguram a cooperativa para buscar novas alternativas econômicas ao trabalho madeireiro. Nos anos seguintes, receberam o apoio da ONG britânica Gaia Foundation para a compra de um barco e para a entrada de um pequeno capital de giro, ao passo que seriam beneficiados no ano seguinte com a verba do BNDES, juntamente com outras quinze etnias da região. Tal verba foi utilizada em 1995 na transferência das famílias para a entrada do rio Amônia.

O apoio dessa rede de colaboradores foi decisivo para pressionar a demarcação de suas terras. Pela primeira vez, Antonio Pianko vai a Brasília, acompanhado de seu filho Moisés, de Margarete Mendes e de Ana Valeria A. Leitão (assessora jurídica do antigo Núcleo dos Direitos Indígenas). Lá, após mobilizarem a mídia, conseguem falar com os representantes da FUNAI, do IBAMA, entre outros órgãos. Essa viagem e a visibilidade que a Aliança dos Povos da Floresta tinha na época vão ser fundamentais para o processo de demarcação, possível com os recursos advindos do apoio do Núcleo de Direitos Indígenas (NDI), da Gaia Foundation, da Overseas Development Agency (ODA) e da World Wildlife Fund (WWF). Finalizada a demarcação, Moisés Pianko e seu irmão Benki, acompanhados de outras lideranças indígenas do vale do Juruá, participaram, em julho, da Eco-92, no Rio de Janeiro. Após essa participação, finalmente a homologação da Terra Indígena Kampa do Amônia sai, em 23 de novembro daquele ano (PIMENTA, 2007, p. 653). 


\subsection{A ERA DOS PROJETOS SUSTENTÁNVEIS E O CENTRO YORENKA ÃTAME}

Após a demarcação de suas terras, os Ashaninka iniciam uma parceria com o antigo Centro de Pesquisa Indígena (CPI), criando um projeto de pesquisa para análise da riqueza do seu território. Dessa maneira, procuraram outras alternativas de sustentabilidade econômica e ambiental. O projeto "Óleos e essências florestais nativas" ocorreu entre 1992 e 1995, financiado pela Chancela da Áustria. É nesse projeto, uma reatulização do ayounpari e das alianças, que os Ashaninka começam a sua história rumo ao "desenvolvimento sustentável" e ao "mercado de projetos" (ALBERT, 2000 apud PIMENTA, 2007). Sua realização envolveu um grupo de jovens Ashaninka treinados para a pesquisa de seus territórios:

Durante esse período, um grupo de jovens ashaninka foi treinado nos procedimentos básicos da pesquisa botânica: identificação de espécies, procedimentos de coleta, extração, processamento das essências etc. Mais de cinqüenta espécies nativas, entre óleos, folhas, polpas, castanhas e outros, foram pesquisadas e catalogadas durante os três anos de duração do projeto.

O potencial econômico de cada produto foi estudado levando-se em consideração a porcentagem de óleo produzida, sua qualidade e a possibilidade do uso das essências na comercialização.

[...] A essa iniciativa se sucederam vários outros projetos, entre os quais, podemos citar: produção e comercialização de sementes, apicultura, recuperação de áreas degradadas, criação de sistemas agroflorestais (SAFs), planos de manejo da caça e da pesca, criação de quelônios, ecoturismo etc. (PIMENTA, 2007, p. 655-656)

Essas experiências exitosas proporcionaram aos Ashaninka grande visibilidade regional, nacional e internacional, redimensionando-os diretamente à imagem de um tipo de "desenvolvimento sustentável amazônico", servindo de vitrine para sua política interétnica e a do governo estadual, à época de Jorge Viana e o Governo da Floresta (1999-2007). Essa visibilidade rendeu aos Ashaninka a oportunidade de ocupar cargos políticos na esfera municipal e estadual, ampliando suas relações com o Estado.

Sem dúvida, os Ashaninka do Amônia tornaram-se os herdeiros diretos da Aliança dos Povos da Floresta, com suas imagens associadas ao manejo e às práticas de desenvolvimento sustentável local. Tais práticas foram também difundidas por eles entre os moradores da região, principalmente como forma de 
evitar a invasão de suas terras e o esgotamento de seus recursos naturais, impedindo as derrubadas e mantendo a presença da caça e dos peixes. A preservação de seus territórios está diretamente relacionada com os modos de uilização dos recursos nele existentes, essenciais a sua sobrevivência física e cultural. Partindo dessa preocupação, elaboraram um plano de gestão territorial e ambiental $^{186}$ para a bacia do Alto Juruá, buscando conscientizar e envolver as comunidades vizinhas nesses projetos, mostrando a importância de alternativas econômicas à exploração predatória de madeira e à pecuária.

Com relação às áreas de pasto, difusas principalmente no assentamento do INCRA, propuseram um importante projeto, o “Ãtame Aniro" (2000). de recuperação de áreas de floresta degradadas com a exploração da madeira e da difusão de áreas de pasto na região. O objetivo do projeto era capacitar as comunidades locais não indígenas do assentamento e da Reserva extrativista do Alto Juruá, e indígenas da região e do lado peruano, na gestão sustentável dos recursos naturais de seus territórios. Embora muito elogiado, o projeto não conseguiu recursos para sua execução. Benki Pianko, em sua gestão como secretário do Meio Ambiente e Turismo do Município de Marechal Thaumaturgo, em 2007, tentou concretizar o projeto, mas, por falta de apoio político e financeiro, novamente os Ashaninka tiveram que postergar a execução do empreendimento.

Pimenta (2007) menciona que o projeto da Escola Yorenka Ãtame, depois transformado em Centro, teve origem no projeto "Ãtame Aniro". De 2005 até a inauguração do Centro os Ashaninka encontram os apoiadores necessários para realizar seu empreendimento, destinando um espaço específico para a materialização do sonho de Samuel Pianko de promover a união entre índios e brancos para a manutenção da floresta, fonte da vida de todos da região.

Como já vimos, a realização desse sonho começa indireta e diretamente por uma via midiática, com o contato com o mundo real dos profissionais construtores de narrativas ficcionais, de imagens e imaginários. Em 2006, Benki Pianko participou de uma oficina preparatória com os diretores, a produção e os atores da minissérie global "Amazônia - de Galvez a Chico Mendes", no Projac, Rio de Janeiro. A autora

\footnotetext{
${ }^{186}$ Tal plano foi posteriormente publicado pela Comissão Pró-Índio e encontra-se disponível para download. No Plano de Gestão Ashaninka estão os acordos e as intenções elaboradas pela comunidade Ashaninka do Rio Amônia. Esses acordos se referem a diversas temáticas, como o uso dos recursos naturais (caça, pesca e plantas), planejamento da aldeia, saúde, vigilância e fiscalização, relação com o entorno, entre outras (Comissão Pró Índio - Acre). Disponível em: http://www.cpiacre.org.br/pdfs/ashaninka_compl_2210.pdf.
} 
da minissérie, Glória Perez nascida no Acre, também participou. Na oficina, Benki contou a vida dos Ashaninka e sua relação com a Floresta, realizou um ritual espiritual e, na oportunidade, por intermédio de João Fortes, apresentou o projeto de construção do Centro Yorenka Ãtame. Prossegue, assim, à articulação de inúmeros apoiadores, entre os quais Luiz Paulo Montenegro, do IBOPE, atores como Marcos Palmeiras e Letícia Spiller, que já haviam visitado o Acre após a participação de Benki e Moisés no Ano do Brasil na França, em 2005.

Nessa mobilização eles conseguiram levantar a verba necessária para a compra do terreno de 86 hectares, uma antiga área de pasto, situado em frente ao município de Marechal Thaumaturgo ${ }^{187}$. Um exemplo bastante concreto de capital social, mobilização de recursos derivada de uma "rede de rede", estabelecida pelas relações dos Ashaninka e da Rede Povos da Floresta (com João Fortes e a ACMA), em que as pessoas e entidades envolvidas se identificam e compartilham valores comuns de preservação da floresta, de disseminação de práticas de desenvolvimento sustentável realizado por seus habitantes tradicionais.

A construção do espaço físico do Centro Yorenka Ãtame foi realizada pelos próprios Ashaninka e pelos moradores do município. Nesse trabalho coletivo foram edificadas: a casa de recepção (com a cozinha), um alojamento com dez quartos, a lavanderia, o escritório do Centro com computadores com acesso à internet, uma sala com computadores do programa GESAC (Ver Anexo1, Apêndice 1 a 6), duas casas tradicionais Ashaninkas, um auditório e uma sala. Tudo construído em madeira, assim como os móveis, feitos pelos mesmos. Na parte central do Yorenka há, no chão, uma estrela com um sol dentro dela e uma lua em formato crescente. As pontas da estrela irradiam os espaços citados. A simbologia ambiental (sol, lua, estrela) está explicitamente imbricada no espaço construído. $\mathrm{Na}$ cosmologia Ashaninka, o deus Pawa é o criador de todo o universo; nele se reinscrevem, em suas criações, a estrela, o sol, a lua ${ }^{188}$. As pontas das estrelas irradiam como se fossem a extensão das ideias e dos projetos de sustentabilidade desses povos. Essa irradiação simbólica só foi possível porque houve uma reelaboração do seu ayonpari, de forma informativa, ecossistêmica e complexa. A materialização do sonho de Samuel Pianko, desse espaço de fomento dos saberes da floresta,

\footnotetext{
187 O Centro está a três horas de barco da aldeia Apiwtxa, situada no município de Marechal Thaumaturgo.

${ }^{188} \mathrm{Na}$ cosmologia Ashaninka, o sol é feminino; a lua é masculina e deu a mandioca aos Ashaninka, sendo uma entidade canibal associada ao mundo dos mortos.
} 
realizou-se pelas conexões reticulares, pelo encontro intersubjetivo intercultural de imaginários.

Inaugurado em 07 de abril de 2007, o Centro iniciou seus trabalhos com a capacitação de jovens índios e não índios, ensinando-lhes principalmente as técnicas dos sistemas agroflorestais e de produção de mel com abelhas nativas, entre outras informações sustentáveis para a manutenção de suas comunidades e da floresta. Esses jovens recebiam alimentação, casa e uma bolsa para a participação nos cursos. Na primeira fase, o Yorenka Ãtame recebeu o apoio da empresa Neutralize, fomentadora de projetos de neutralização de carbono. Conseguiu, assim, iniciar um projeto de reflorestamento da própria área do Centro $^{189}$. Em 2008, continuaram com o Projeto de Implantação de Sistemas Agroflorestais (Safs), manejo da meliponicultura e criação de quelônios (tracajás), com o apoio do Programa Áreas Protegidas da Amazônia (Arpa), por intermédio do Fundo Brasileiro para a Biodiversidade (Funbio). Esses projetos foram coordenados por Benki e por Sheyla Sant'Anna, gestora técnica e parceira da comunidade.

Nos anos seguintes eles deram continuidade aos seus trabalhos, fazendo desse espaço um ponto de referência de ação para a sustentabilidade no município de Marechal Thaumaturgo. Quando estive a campo, Benki Pianko estava se preparando para ir a Brasília, visitar a Fundanção Banco do Brasil, com vistas a assinar a parceria, com essa instituição, um contrato para a criação de sistema de psicultura com peixes da região, no intuito de produzir para prover a subsistência do grupo de jovens que trabalha voluntariamente e para a venda de peixes para a população do município.

\footnotetext{
${ }^{189}$ Naquele ano começava também a execução do projeto Nanipini de neutralização de emissão de carbono com o reflorestamento na região de 150 espécies de viveiro no Yorenka. Na época conseguiram três clientes: a banda inglesa The Police, que neutralizou a emissão de carbono gerada na turnê pelo Brasil, em 2007, com a plantação de quatrocentas árvores; a Cantão, que neutralizou seus desfiles nas terras da aldeia, com cerca de trezentas árvores; e o chefe de cozinha Claude Troisgros, que ganhou de presente árvores para neutralizar o carbono emitido na festa do seu casamento, em março daquele ano (RPF, 2007).
} 


\subsection{NOS CIRCUITOS DA ECOLOGIA XAMÂNICA COMUNICATIVA ASHANINKA}

Ao imergir, interagir e dialogar nos circuitos da ecologia xamânica comunicativa indígena reconstruí o que Arjun Appadurai denomina mediascape. Essas paisagens midiáticas são ocasionadas pelo cruzamento do global com o local e pelos recursos eletrônicos de produção de imagens que modificam a nossa percepção de mundo. Como mencionamos anteriormente, o papel da mídia (e das interações com os sujeitos enunciadores de identidades étnicas) na construção dessas paisagens midiáticas aponta para a mobilização de repertórios imagéticos e para a importância da imaginação nos processos de construção da localidade e das identidades de grupo em condições diaspóricas (sincréticas e transculturais) e de afirmação de suas diferenças culturais. No caso dos Ashaninka, temos três mediascapes: paisagens midiáticas audiovisuais; paisagens midiáticas sonoras; e paisagens midiáticas digitais. As duas primeiras estão também presentes nas redes digitais e foram digitalizadas durante o processo de registro, de composição, de distribuição e de circulação.

\subsubsection{Mediascape I - paisagens midiáticas audiovisuais}

Além de todo esse trabalho de manejo e reflorestamento dentro de uma percepção ambiental sustentável, o registro da memória, da cultura, da língua, por meio de produções audiovisuais é uma das realizações do Centro. Os Ashaninka já tinham realizado alguns documentários em parceria com o Vídeo nas Aldeias. Com a transformação do Yorenka em um Ponto de Cultura Indígena (2009-2010) eles puderam realizar outros projetos audiovisuais, que ainda não foram editados. Assim, a digitalização impulsionada pelo convênio da RPF com os Pontos de Cultura Indígena proporcionou a potencialização de produções audiovisuais tanto Ashaninka quanto dos jovens do município de Marechal Thaumaturgo. 
No caso dos Ashaninka, sua forte cultura oral ${ }^{190}$ contribuiu para o sucesso do audiovisual entre eles, fazendo do vídeo uma poderosa mediação cultural capaz de englobar o fundamental da comunicação indígena: a oralidade e a corporalidade. Suas narrativas orais ganham visualidade e uma temporalidade desterritorializada, fora do tempo e do espaço da sua enunciação. Eles percebem, assim, que suas narrativas tornam-se discursos enunciadores de suas identidades étnicas. A escolha do que deve ser registrado incide diretamente naquilo que o grupo pensa sobre si e no que deseja que se pense sobre ele. Aqui cabe, novamente, a metáfora do espelho: o vídeo como espelho e reflexo de si, criador de múltiplas imagens reveladoras do processo tecno-imagético-intersubjetivo de reconhecimento da sua alteridade e singularidade.

Andréa França (2006, p. 198) sublinha justamente essa consciência indígena do processo de filmagem que expõe o jogo entre quem filma e quem é filmado, "um jogo em que a performance dos índios está ligada a fatores que são produzidos 'pelo' documentário, 'para' o documentário e que não existiriam sem ele”. Essa mesma performance, exercida no processo de filmagem, condicionada a essa tecnologia e a suas linguagens específicas, entrelaça-se à de se autorrepresentar no audiovisual.

Além disso, estamos diante de uma transformação de largo alcance não só no empoderamento desses sujeitos indígenas nos modos de se autorrepresentar e de se apropriar de suas próprias imagens, mas na nova inserção desses sujeitos "realizadores" indígenas ${ }^{191}$ que se apresentam como agentes produtores desses imaginários e são reconhecidos, interna e externamente, por seus trabalhos audiovisuais, cenário em que a arena do conflito interétnico não é mais a tradicional, mas a do campo da comunicação e da produção do imaginário. Narrar suas culturas

${ }^{190} \mathrm{Na}$ Apiwtxa há uma escola indígena frequentada principalmente pelas crianças. Não obtive dados sobre o percentual de alfabetizados. Na família Pianko, todos estudaram fora da aldeia. Todos da aldeia falam a língua Ashaninka, além de espanhol e um pouco de português (a língua Ashaninka é corrente entre eles). Alguns de seus mitos e narrativas foram, ao longo dos anos, registrados pelos antropólogos Mendes (1991), Pimenta (2002) e Lessing (2011).

191 "Realizador indígena" significa aquele que produz o vídeo, capta as imagens e participa do processo de edição, termo similiar à "cineasta". Cabe destacar que a produção audiovisual dos sujeitos realizadores Ashaninka se submete às regras locais, ao consentimento dos velhos ou das lideranças Ashaninka (Antonio Pianko, Aricemi, entre outros). Desde já é um processo colaborativo adequado à estrutura social indígena. Ao mesmo tempo, a realização do vídeo se submete aos interesses e às lutas políticas internas. Ver: CARELLI, V. Crônica de uma oficina de vídeo. São Paulo, agosto de 1998. Disponível no site do Vídeo nas Aldeias: http://www.videonasaldeias.org.br/2009/biblioteca.php?c=24. Acesso em: 21 fev. 2010. 
por meio do audiovisual ganha uma densidade poética e política muito mais sofisticada que - as também válidas - ações de ocupação de espaços públicos.

Por meio da temática adotada nos vídeos, suas identidades são performatizadas, suas memórias registradas e apresentadas para o público, seja ele indígena e/ou não indígena, possibilitando uma reflexão coletiva, baseada na visibilidade e na atualização dessas realidades. Com a interação com a comunidade, a produção audiovisual indígena ocasiona um processo de autoconsciência coletiva da sua diversidade e das mudanças ocorridas em suas culturas, ao mesmo tempo em que fornece os meios de fortalecê-las. É nesse sentido que Isaac Pianko (Isaac Pinhanta), irmão de Benki, professor e realizador, diz:

Aí eu comecei a perceber que o vídeo podia servir para discutir a
nossa cultura, organizar a escola, pensar em todo nosso sistema de
vida. Por mais que o povo fale sua própria língua, tenha a cultura
forte, tem algo de fora que também está entrando ali e a gente não
está nem percebendo. Então o vídeo serviu muito nas discussões
com a comunidade, por exemplo, para que usar o gravador, para que
serve a TV. Foram discussões grandes.
[...]
Por mais que a gente trabalhe a cultura, trabalhe a língua, a gente
vai mudar, algo vai mudar ali dentro, como já mudou. Só a escola já
é uma coisa diferente. O vídeo também é uma coisa diferente. Mas a
questão não é ser diferente, a questão é como utilizar a imagem. Se
a pessoa conta uma história, através do vídeo, você pode incentivar
várias crianças a querer aprender aquela história. Dentro da escola,
o vídeo pode ajudar muito a pessoa refletir sobre si mesma, porque o
contato trouxe muita desorganização para o nosso povo, e se você
não encontrar uma alternativa de reflexão, para você olhar seu valor,
isso acaba. (PINHANTA, 2004, p. 4)

Esse processo de transformação da cultura Ashaninka, compreendido por eles como um risco, é muito diferente daquela interpretação baseada na imagem estereotipada de índios produzida pela sociedade nacional. As imagens produzidas pelos não índios são descoladas e evasivas da realidade indígena. Como sublinha James Clifford (1993), não existem figuras puras que enlouquecem, mas figuras emergentes que desafiam as várias formas de representação baseadas em clichês de índios puros e autênticos. Assim, a produção audiovisual Ashaninka desencadeia, ao mesmo tempo, uma consciência e uma revitalização dessa cultura, provocando uma desconstrução do olhar não indígena sobre a cultura nativa.

Dessa forma, os Ashaninka puderam mostrar nos vídeos principalmente a atuação deles nos projetos de manejo e reflorestamento, comentados anteriormente 
no item 3.2.7, "Galeria de vídeos". Além disso, durante a vigência do convênio com os Pontos de Cultura Indígena e a Rede Povos da Floresta, eles produziram o documentário "Uma aldeia chamada Apiwtxa" (de Txirotsi Ashaninka, 2010) e outro sobre o ensino dos velhos às crianças Ashaninka (material ainda não finalizado) ${ }^{192}$. No Youtube encontram-se disponíveis alguns vídeos ${ }^{193}$ em que Benki Pianko fala do trabalho realizado no Centro Yorenka Ãtame com os jovens da região. Recentemente esse coletivo transformou-se em uma Associação, chamada "Jovens Guerreiros da Floresta" ${ }^{194}$. Esse tipo de produção midiática, indicador de um processo de digitalização (registro e disponibilização on-line), reforça a discursidade audiovisual dos empreendimentos e identificações da cultura Ashaninka. É um tipo de material que dá visibilidade a seus trabalhos, legitimando-os; contemporaneamente, dá acesso a suas realizações, potencializando novos contatos, novos inputs nas redes.

192 Informação obtida por meio da entrevista com Benki Pianko, realizada em $1^{\circ}$ de dezembro de 2012.

193 Entre eles, “Centro Yorenka Ãtame - Projeto 'Jovens Guerreiros da Floresta'”. Disponível em: http://www.youtube.com/watch?v=nb6i02s2l6E.

${ }^{194}$ Quando estive no Yorenka conheci alguns desses jovens. Como contrapartida de minha visita, me dispus a assessorá-los na elaboração de um projeto que possa financiar o trabalho por eles realizado no Centro. Vi de perto o trabalho duro desses jovens na manutenção do espaço, no plantio de mudas, entre outros. Todos, segundo Benki, estão envolvidos no Centro Yorenka porque acreditam no projeto, possuem aquilo que ele chama de "firmeza", sem receber nenhum tipo de remuneração. Embora tenham abundância de frutas, a alimentação é provida com alguma dificuldade. Aproximadamente dez jovens, entre 19 e 26 anos, que trabalham no Yorenka se alimentam lá durante os trabalhos e jantam na casa de Benki em Marechal Thaumaturgo. Essa casa, também conhecida como "Banho do Beija-Flor-Benki", localiza-se no assentamento do INCRA, com um igarapé e parte de sua área reflorestada por Benki com a ajuda dos jovens. Lá ele vive com sua mulher, Célia, filha de seringueiros, com a qual teve um filho, Piongare, de três anos, e seu filho "Heiken", de 14 anos, fruto de seu outro matrimônio com uma mulher Ashaninka. Além de Heiken, Benki teve mais seis filhos com ela, mas se separou e foi morar em Thaumaturgo com o aval de seu pai. Opção estratégica para cuidar do Yorenka Ãtame, que está a três horas de barco da Aldeia Apiwtxa (ver Apêndices 8, 9, 10). No espaço que mora atualmente há alguns anos Benki manteve um bar, um "club" na expressão local, que funcionou por dois anos, mas que, segundo ele, Ihe deu "muita dor de cabeça". Naquela época, "gostava muito de festa, eu tocava de tudo neste espaço", mas, embora tenha sido muito frequentado pelo povo da região, o consumo de bebidas alcoólicas acabava ocasionando momentos de tensão e brigas. Sua opção de desativar esse espaço, atualmente a casa onde abriga os jovens, convidados, pesquisadores como eu, coincide com seu maior envolvimento na espiritualidade Ashaninka. Nesse espaço, como xamã e líder desses jovens, realiza rituais de cura e encontros coletivos para o uso da Ayahuasca, acompanhados de muita música em português e em Ashaninka relativas à Floresta e ao próprio chá. Com esses jovens, além de manter o Yorenka Ãtame, estão construindo o "Raio de Sol", um grande centro espiritual, situado dentro do assentamento do INCRA, há quarenta minutos de moto. Lá eles construíram seis casas tradicionais em estilo Ashaninka, formando um círculo, em uma parte alta, muito sugestiva, o qual ele deseja que se torne um grande centro espiritual internacional de cura. Seu projeto é construir um grande barco em madeira que possa metaforicamente "conduzir" os passos da civilização. O terreno do Raio de Sol foi doado pelo pai de sua atual esposa. 


\title{
4.3.2 Mediascape II - paisagens midiáticas sonoras
}

Outro elemento muito forte entre os Ashaninka é a música, com seus cantos, ritmados por flautas e tambores, conseguiram digitalizar uma parte desse acervo imaterial do grupo. Uma pequena parte desse patrimônio foi registrado em um projeto coordenado por Francisco Pianko, com a participação de Benki, Isaac e Moisés, e transformou-se no CD "Homãpani Ashaninka" (ver Anexo 2), produzido em 2000 e reeditado em 2005. Isaac Pianko (Isaac Toto Pinhanta) assim apresenta esse trabalho:

\begin{abstract}
Hoje, lançamos a segunda edição deste CD com músicas que conseguimos guardar dos nossos antepassados até hoje. As músicas do Piyarentsi trazem momentos de tristeza, emoções e alegrias que pedem forças aos pássaros e plantas específicas para a gente superar todas as dificuldades. As músicas do Kamãrapi são para os momentos de concentração, para ouvir a natureza falar e passar seus conhecimentos para o âtawiyari, que é uma pessoa muito respeitada por todos os Ashaninka, que conhece todos os segredos que Pawa deixou na terra. A gravação deste CD quer mostrar para sociedade quem é o povo Ashaninka, o que diz nossa música e nossa cultura. Não apenas diversão, mas todo um conhecimento que garante a sobrevivência do nosso povo, fazendo a relação da música com os animais, com a floresta, as plantas, estrelas, lua, sol e água. Este CD assegura a preservação de nossas músicas e pode trazer outras músicas de volta, que estão com alguns, mas não são praticadas. (Isaac Toto Pinhanta, 2005) ${ }^{195}$
\end{abstract}

A faixa 13 deste CD, intitulada Kamrãpe, é particularmente envolvente. Nessa mesma faixa foram registrados vários cantos entoados por Arisemi (importante 'guardador' do acervo musical Ashaninka ${ }^{196}$ ), Iririta e Benki, em rituais do Kamrãpe, Kamarãpe ou Kamarampi (da Ayahuasca em Ashaninka). Nesses cantos, ora embalados com o som dos pássaros ao fundo, sem os arranjos dos instrumentos, ora entoados com seus ritmos e sopros, mergulha-se em um ritmo místico dessa paisagem sonora (soundscape).

Desse material acessa-se um pouco da cosmologia Ashaninka, marcada por uma forte dualidade, característica dos sistemas cosmológicos xamânicos das terras

\footnotetext{
${ }^{195}$ Texto retirado do encarte do CD "Homãpani Ashaninka", 2005.

${ }^{196}$ Quando visitei a aldeia Apiwtxa, em novembro de 2012, conheci o antropólogo Izomar Lacerda, que realizava sua pesquisa de doutorado sobre a música Ashaninka.
} 
baixas da Amazônia, como vimos anteriormente. Nesse universo xamânico guardase parte do mistério da cosmologia Ashaninka. Na mesma faixa 13 do CD "Homãpani Ashaninka”, Arisemi e Iririta repetem "Tsera Tsera Mai Piyawota Nanarie Hehe" - palavras mágicas ligadas ao pássaro Japinim ${ }^{197}$ e de tradução não permitida.

A música transmite energias de amor, espirituais e formas como Deus [Pawa] monta a natureza e manda ela para nós. Tem músicas que você canta para espantar o mal e trazer a energia do bem. Tem as que você canta louvando a Deus [Pawa] e pedindo vida longa. (Moisés Pianko, 21/09/2004) $)^{198}$

\section{A digitalização dos cantos e da cosmologia Ashaninka reproduzida}

tecnicamente fortalece a aura da cultura e do lugar ashaninka, em um nível comunicativo e estético ${ }^{199}$ bastante peculiar. Na discussão sobre a reprodução técnica das obras de arte tem-se que, para Benjamim (1996), a aura é um conceito chave que passa a interferir na transformação da percepção humana, associada à originalidade e ao conjunto de características que tornam única a obra de arte em questão. Com sua reprodução técnica, também sua aura sofrerá transformações radicais: "Se antes a aura de uma obra de arte - seu aparecimento único, seu aqui e agora - estava nela mesma, as novas artes, surgidas do processo técnico, fazem

197 Japinin ou Japiim (cacicus cela) é um pássaro muito respeitado e admirado por todos os habitantes da floresta por ser capaz de imitar o canto ou a fala de qualquer outro animal, pelos seus elaborados ninhos e por seu modo de vida (CUNHA e ALMEIDA, 2002, p. 523). É um tipo de japó (Psarocolius spp., família Icterinae): "Com efeito, os Ashaninka do alto Juruá têm uma consideração muito especial por toda a família dos japós. Em seu conjunto (que abarca a família Icteridae), os japós são chamados pelo nome genérico txowa, que designa também uma espécie particular, o Psarocolius sp. Todos os japós são humanos. Isto todo mundo percebe, já que eles vivem em sociedade, e tecem seus ninhos: são, em suma, tecelões como os Ashaninka. Os xamãs que, sob o efeito do ayahuasca, sabem ver de forma adequada, comprovam essa condição humana dos japós: vivem ao modo dos homens, cultivam mandioca, bebem kamarãpi (ayahuasca), bebem cerveja de mandioca (caissuma). São inclusive superiores aos homens, na medida em que observam a paz interna e vivem sem discórdia. São os filhos que Pawa, o sol, deixou na terra, são os filhos do ayahuasca" (CUNHA, 1998, p. 15 apud LESSIN, 2012, p. 33).

198 Disponível em: http://agenciabrasil.ebc.com.br/noticia/2004-09-21/ashaninka-e-povo-indigenamais-numeroso-da-america-do-sul. Acesso em: 19 nov. 2011.

199 Moisés e Benki Pianko, ambos xamãs, possuem pinturas que retratam o universo cósmico Ashaninka de modo bastante peculiar. Os motivos envolvem os seres da floresta, os próprios Ashaninka e suas conexões com o mundo xamânico. Na Aldeia Apiwtxa, na casa de Antonio Pianko e D. Piti, um quadro de Moisés reteve minha atenção: o corpo de um ashaninka mistura-se com a copa de uma árvore ramificada em suas extremidades. Exemplo notório de uma estética xamãnica e reticular, em que cultura e natureza hibridizam-se. Na tese de Leonardo Lessin (2011), disponível on-line, encontrei a reprodução de uma pintura de Benki que estava no salão de sua casa quando o visitei. É uma obra impressionante por sua capacidade de retratar esse rico universo xamânico, comunicante de uma espacialidade híbrida, simbiôntica, pós-humana (Ver Anexo 3). 
com que a força estética passe a derivar-se agora da própria técnica" (MARCONDES FILHO, 2009, p. 33).

Se, na história ocidental, as formas estéticas viram sua passagem de uma arte aurática para a arte reproduzida em série - sem aura, sem aquela originalidade e autenticidade - no caso da digitalização dessas formas estéticas Ashaninka (sobretudo cantos e pinturas) essa aura como emanação de suas cosmologias ganha uma extensão digital para além da sua reprodução ritual local. Baseando-se na etimologia da palavra aura em latim, significando "sopro", em conformidade com a capacidade expansiva e perceptível do invisível, a musicalidade Ashaninka digitalizada se expande como o vento, passando e deixando rastros, ainda que não esteja em seu lugar original e em sua temporalidade sincrônica. O registro desses cantos imortaliza, retira o aqui e o agora do ritual para uma (a)temporalidade e perpetuação digital, que, quando ouvimos, é presentificada em nossos contextos, reterritorializando-se. Forma-se assim, camadas sobrepostas de temporalidades (a dos tempos míticos ashaninka e a do local reproduzido) e espacialidades comunicativas ubíquas (ouço Tsera Tsera Mai Piyawota Nanarie Hehe e 'estou' na floresta, 'estando' em São Paulo, testemunho as palavras mágicas para japinim, estou no tempo e no espaço Ashaninka).

\subsubsection{Mediascape III - paisagens midiáticas digitais}

Como dito anteriormente, após perscrutar o site da RPF, rastreei a experiência do Yorenka e dos Ashaninka nos circuitos das redes socias digitais. 
Localizei o blog Saberes da Floresta ${ }^{200}$, bem como o blog da Apiwtxa ${ }^{201}$, e o grupo do Centro Yorenka Ãtame e o perfil de Benki Pianko no Facebook ${ }^{202}$.

Os dois blogs possuem o mesmo layout verde do Blogspot do Blogger do Google (publicação gratuita): fundo verde, ambos assinados pela Associação Apiwtxa, com hipertextos, fotos e vídeos. Com arquitetura simples e a possibilidade de inserção de comentários, os blogs, principalmente o da Apiwtxa, representa singularmente a presença Ashaninka do Rio Amônia na rede digital. O Centro Yorenka Ãtame, Saberes da Floresta, conta com poucos posts (23), publicados entre 2007 e 2009, nos quais mostra principalmente as atividades decorrentes da implantação da Escola Saberes da Floresta e das mensagens de Benki Pianko para os parceiros apoiadores do Centro. Por esse motivo me detetive na análise do blog da Apiwtxa.

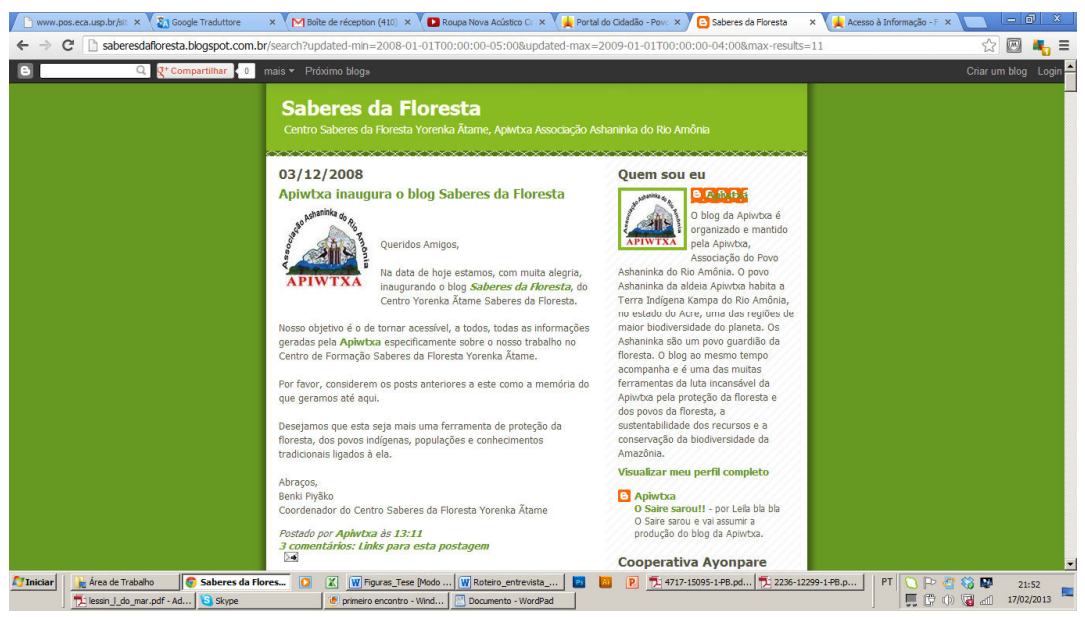

Figura 8 - Captura da tela do Blog Saberes da Floresta

200 O blog Saberes da Floresta (disponível em: http://saberesdafloresta.blogspot.com.br/) foi criado em 06 de junho de 2007, antes da inauguração do Centro. Desde a finalização deste capítulo registrei o último post com data de 07 de setembro de 2009, anunciando a criação do site do Centro Yorenka Ãtame (até o momento este não foi finalizado e tampouco publicado).

201 O blog da Associação Ashaninka do Rio Amônia (apiwtxa.blogspot.com) foi criado alguns dias antes do blog do Yorenka Ãtame, em $1^{\circ}$ de junho de 2007. Seu último post resgistrado é do dia 30 de setembro de 2011, anunciando a "Operação Copaíba" da Polícia Federal de apuração da extração ilegal de madeira em terras Ashaninka. Baseado em uma denúncia realizada pelos Ashaninka, a Polícia Federal, o Exército, o ICMBio e a FUNAI fizeram sobrevoos na região para investigação, mas não conseguiram prender os invasores.

202 Presente desde 2011 no Facebook, o perfil de Benki Pianko tem muitas fotos dele e dos encontros dos quais participou. Muitas fotos e comentários são das pessoas que acompanham o trabalho dele, boa parte amigos e admiradores. A reputação dos Ashaninkas como povos guerreiros e guardiões da floresta é seguidamente reforçada. O perfil do Centro Yorenka Ãtame, no ar desde maio de 2012, encontra-se pouco atualizado, com fotos das atividades de manutenção do espaço realizada pelos jovens. Ambos perfis, ainda que sem atualização frequente, servem para conectálos. Conversei algumas vezes com Benki nessa arquitetura informativa. 
Nele há a divulgação da Cooperativa Ayonpare, com a venda de artesanato Ashaninka. São mostradas fotos no Picasa (site de compartilhamento de imagens) dos diversos itens de artesanatos: tambores, kusmas, flautas, bolsas, colares, CD's e DVD's com a produção audiovisual deles. Através do e-mail de contato é possível adquirir esses produtos, vendidos também na sede da Cooperativa, na aldeia Apiwtxa e no escritório deles em Cruzeiro do Sul, mais uma prova da reatualização do sistema tradicional de troca (ayonpare) no caso do artesanato, com o digital. $\mathrm{O}$ ayonpare é agora também digital.

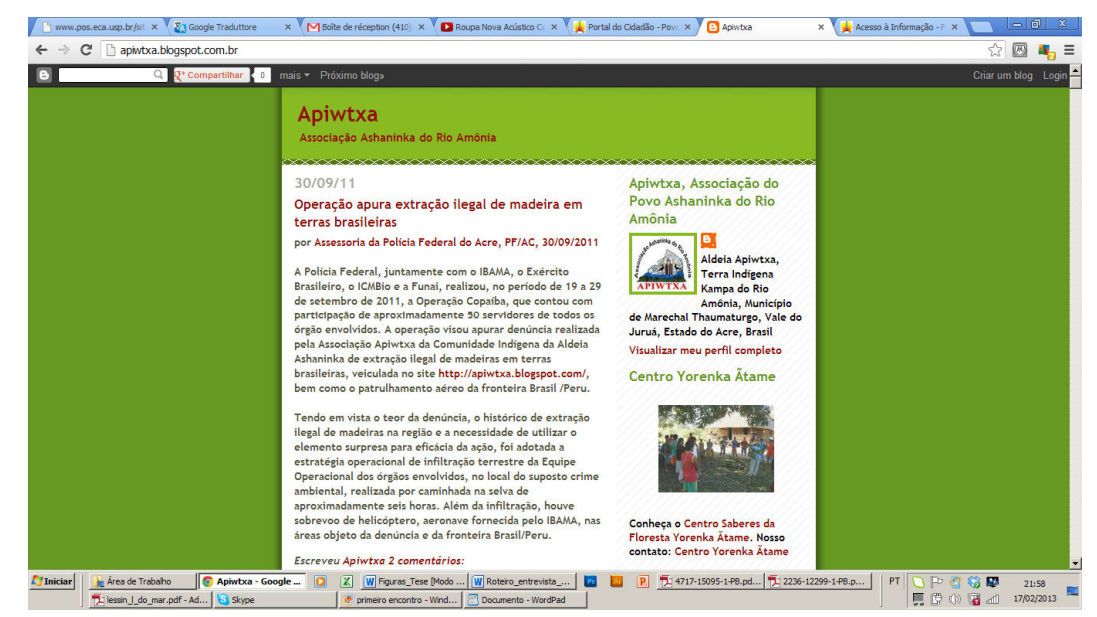

Figura 9 - Captura da tela blog da Associação Ashaninka Apiwtxa.

Nessa arquitetura informativa são divulgados todos os prêmios recebidos por eles. "Prêmio Culturas Indígenas", MinC, na categoria artesanato (2009); "Ordem do Mérito Cultural" (2008), categoria Associação; "Prêmio Chico Mendes", $1^{\circ}$ lugar, categoria Associação Comunitária (2007). Essa reputação do grupo é fortemente associada à preservação cultural, à tradição do conhecimento Ashaninka, e isso traz o reconhecimento desse trabalho tanto no âmbito nacional quanto internacional.

De um total de 304 posts publicados entre 2007 e 2010, parte deles foi escrito por Leila Soraya Menezes, da Rede de Cooperação Alternativa Brasil $(\operatorname{RCAB})^{203}$, e por Benki e Isaac Pianko. Também há a publicação de matérias de agências de notícias de oganizações governamentais e não governamentais correlacionadas ao trabalho da Apiwtxa. Os assuntos tratados mostram uma cartografia do conflito, em que o território Indígena do Kampa sofre recorrente invasões: dos madeireiros

${ }^{203}$ Com sede em São Paulo, a RCAB é uma rede de cooperação alternativa integrada pelas organizações indígenas e indigenistas: Comissão Pró-Índio/AC, Centro de Trabalho Indigenista, Instituto Socioambiental, entre outras. 
peruanos (principalmente da Empresa Foresta Vedeo), dos narcotraficantes, dos caçadores ilegais. Além disso, há problemas indiretamente associados aos seus territórios: a prospecção de petróleo e gás na região e a questão dos índios isolados ameaçados pelos madereiros e narcotraficantes.

Para combater a invasão em suas terras, quando constatadas, além de realizar as denúncias diretamente para os órgãos competentes (Polícia Federal, Exército, IBAMA e FUNAI) eles mesmos passaram a utilizar o georreferenciamento com GPS, anotando as coordenadas e repassando para os órgãos de fiscalização. Tais denúncias ocasionaram duas operações da Polícia Federal, IBAMA, FUNAI e Exército: "Operação Curare" (2008), deflagrada para coibir crimes ambientais, tráfico de drogas e de animais e retirada de madeira; e a "Operação Copaíba" (2011), com os mesmos objetivos e órgãos envolvidos.

Em 2007, a Apiwtxa e a Asociación de Comunidades Nativas de Ashaninkas de Masisea y Calleria (Aconamac) divulgaram uma carta assinada em conjunto denunciando as madeireiras peruanas Venoa, RuBem e Cabrera junto à Organização Internacional do Trabalho (OIT). Seu conteúdo referia-se às derrubadas promovidas ilegalmente em terras indígenas, além de indicar a presença de índios isolados na região e a disseminação de álcool entre eles feita por essas empresas ${ }^{204}$.

A Apiwtxa divulgou em seu blog o e-mail da SmartWood/Rainforest Alliance que certificou em 2007, com o padrão FSC, a empresa Forestal Venao, madeireira peruana, principal responsável pelos desmatamentos ilegais na fronteira Brasil-Peru, para que os internautas e apoiadores da rede enviassem e-mails para eles solicitando a urgente revisão da Certificação (Apiwtxa, 2008). Embora não tenha impedido a certificação, essa ação difundiu em diversas redes de apoio a péssima reputação que a empresa tem por causa da extração ilegal de madeira.

Uma série de ações "desenvolvimentistas" de integração física e energética vem sendo planejada pelos governos peruano e brasileiro, desde a pavimentação da Rodovia Interoceânica, em fase de planejamento, até a construção de uma estrada e de uma ferrovia ligando o município de Cruzeiro do Sul a Pucalpa (Peru). Já a

${ }^{204}$ A comunidade Ashaninka de Sawawo Hito 40 (Peru) se aliou à empresa madeireira Forestal Venao, de Pucalpa, para tentar superar as dificuldades causadas pelo isolamento e pelo descaso do governo. Primando pelo investimento em saúde na comunidade, eles firmaram um contrato de exploração do uso da madeira entre 2002 e 2007. Perceberam que, além de terem recebido muito pouco para a extração, causaram um enorme impacto ambiental em seus territórios. Desde então vem realizando o reflorestamento na região. 
parceria energética visa promover a produção e a exportação de energia hidrelétrica e a integração de empreendimentos de empresas estatais e privadas - brasileiras e peruanas - nas áreas de petróleo e gás. Sua prospecção já está acontecendo no lado peruano, realizada pela empresa brasileira Petrobras.

As associações indígenas e extrativistas da região vêm discutindo esses processos de integração para que sejam respeitadas por esses governos as recomendações da Convenção 169 da Organização Internacional do Trabalho (OIT) e da Declaração das Nações Unidas sobre os Direitos dos Povos Indígenas. Essas recomendações garantem o direito das comunidades e organizações à realização de consultas prévias consentidas a respeito das políticas oficiais de desenvolvimento e de "integração regional" que venham a afetar seus territórios e modos de vida (CHAVES, 2010). Vários encontros relacionados à gestão de seus territórios foram registrados no blog, apontando para um esforço de um diálogo em comum entre os Ashaninka, os outros povos indígenas envolvidos e os órgãos de apoio, principalmente a Comissão Pró-Índio do Acre e o governo do Estado ${ }^{205}$.

Por ter afetado diretamente o território Ashaninka, cabe destacar, aqui, duas ações civis acionadas pela FUNAI e pelo Ministério Público em nome dos Ashaninka do Rio Amônia. A primeira, o Instituto Nacional da Propriedade Industrial (INPI), acusa a indústria de cosméticos Natura, a Chemyunion Química Ltda. e o empresário Fábio Dias Fernandes, proprietário da empresa Tawaya, de Cruzeiro do Sul (AC), fabricante de sabonete de murmuru, de se apropriar indevidamente de conhecimentos tradicionais dos Ashaninka da aldeia Apiwtxa do Rio Amônia. Em outra ocasião, Pimenta (2002) relata o processo de pesquisa realizado em conjunto entre os Ashaninka e Fabio Dias Fernandes, do qual resultou o produto comercializado pela Tawaya. Ao todo, esse processo renderá a esse povo cerca de dois milhões de reais como indenização. A acusação de biopirataria refere-se ao uso do ativo de murmuru (Astrocaryum ulei Burret).

A segunda ação civil é contra Oleir Cameli e Abrahão Cândido da Silva, acusados por danos (materiais, morais e ao meio ambiente) resultantes de invasão da terra indígena Ashaninka do Rio Amônia, abertura irregular de estradas, derrubada de árvores e retirada de madeira na década de 1980, que causaram, à

205 Desde 2004, a Comissão Pró-Indio do Acre e a SOS Amazônia coordenam o Grupo de Trabalho para a Proteção Transfronteiriça da Serra do Divisor e Alto Juruá, grupo de instituições que debatem as questões da fronteira e os impactos sobre os povos da região (CHAVES, 2010). 
época, enorme impacto na comunidade Apiwtxa. Em 2008, a Justiça do Estado do Acre condenou Oleir Cameli e Abrahão Cândido da Silva a pagar indenização ao povo Ashaninka no valor aproximado de 15 milhões. Após o fim dos recursos, essa decisão final ainda aguarda decisão no Superior Tribunal Federal. Os Ashaninkas vêm fazendo uma coleta de assinatura via Avaaz.com ${ }^{206}$ para que o processo seja julgado rapidamente, evitando que prescreva.

Ao divulgar o conteúdo desse conflito, o blog promove tanto a defesa do território e da cultura Ashaninka por uma ação informativa mobilizadora de apoios capazes de pressionar os órgãos do governo competentes para a fiscalização da região, como divulgam as ações de sustentabilidade da comunidade.

Uma série de links de outras redes parceiras nos dá a dimensão da reticularidade da Apiwtxa: ActionAid; Aidesep; Asociación Interétnica de Desarrollo de la Selva Peruana; Associação do Movimento dos Agentes Agroflorestais Indígenas do Acre (AMAAIAC); Amazônia.Org; Associação Nacional de Ação Indigenista (ANAI); Autres Brésils; Biblioteca da Floresta Marina Silva; Brasil Sustentável; Centro de Mídia Independente (CMI Brasil); Coordenação das Organizações Indígenas da Amazônia Brasileira (COIAB); Coordenadora das Organizações Indígenas da Bacia Amazônica (COICA); Conselho Nacional dos Seringueiros; Documentary Educational Resources; France Libertés-Fondation Danielle Mitterrand; FSC-Watch; FUNAI; Fórum Amazônia Sustentável; Gesellschaft für bedrohte Völker (GfbV); Global Voices; Governo do Estado do Acre; IBAMA; ICRA International; Instituto Socioambiental (ISA); Ministérios da Defesa, do Meio Ambiente e da Cultura; Museu Emílio Goeldi; Natureparif; Organização Internacional do Trabalho (OIT); Organização dos Professores Indígenas do Acre (OPIAC); Organização do Tratado de Cooperação Amazônica (OTCA); Pastoral Fluvial; Polícia Federal; Página 20; Rainforest Foundation Norway; RCA Brasil; Universidade Federal do Acre (UFAC); Universidade da Floresta; Warã Instituto Indígena Brasileiro.

Além das já citada, há outras instituições com projetos em parceiras: Rede de Amigos da Escola Yorenka Ãtame (organizada por Luis Paulo Montenegro do IBOPE); Brasilien Magazin; Centro de Democratização da Informática (CDI); Clara

\footnotetext{
${ }^{206}$ Avaaz.com é uma "comunidade de mobilização online" e dá nome à fundação global matenedora. Nessa plataforma aberta é possível elaborar petições, enviá-las por e-mail, coletando assinaturas e novas adesões, articulando-se com outras redes sociais digitais. Sua forma aberta e de fácil disseminação colabora para mobilizações instantâneas.
} 
Projetos Especiais; Comissão Pró-Índio do Acre (CPI/AC); Funbio; Manitou Foundation; Vídeo nas Aldeias; e Rede Povos da Floresta.

\subsection{CONECTIVIDADE}

Ao perscrutar o nível de conectividade digital, busquei detalhar a qualidade e a frequência da conexão, tanto do Yorenka Ãtame como da Aldeia Apiwtxa. Como constatei na pesquisa de campo, os espaços possuem computadores com acesso à Internet (conexão lenta, de aproximadamente $100 \mathrm{~kb}$ ), sendo fundamental para o fortalecimento da conexão com suas redes de apoio. No entanto, me chamou a atenção que a conectividade entre essas redes seja igualmente reforçada com o uso de dispositivos móveis (celulares). Eles já fazem parte dos corpos dessas pessoas e encarnam essa mobilidade em seu sentido pleno. Pelas dificuldades geográficas, uma única operadora oferece esse serviço na região de Marechal Thaumaturgo, a OI, que, com seu sistema de bônus para ligações para celulares dessa operadora, torna bastante viável a comunicação entre eles e seus contatos e redes.

Particularmente, o modo como os Ashaninka se inserem nesse processo de digitalização merece algumas observações. Na visita de campo e em conversas com Benki Pianko soube que a internet é submetida às regras de uso local, aos "critérios de uso", segundo ele. O acesso não é indiscriminado entre todos os Ashaninka da comunidade Apiwtxa. São os professores indígenas da comunidade e as lideranças indígenas, pesquisadores, entre outros, de fora da comunidade, que utilizam esses equipamentos. No Yorenka Ãtame a "chave"207 da sala está disponível para todos os jovens que queiram acessar, mas na Apiwtxa a "chave" está com D. Piti, mãe de Benki. Um dos argumentos alegado por Benki deve-se ao fato da dificuldade de manutenção dos equipamentos na Aldeia. Não há técnicos em informática entre os Ashaninka e a Aldeia está a três horas de barco de Marechal Thaumaturgo, para

${ }^{207}$ A porta da sala de acesso aos computadores é fechada para segurança dos equipamentos e para evitar a entrada de animais peçonhetos (cobras e aranhas). Segundo Benki, o Centro foi assaltado uma vez e roubaram aproxidamente cinquenta mil reais em equipamentos, principalmente motores de barcos e cortadores de grama. Isso fez com que o Centro estabelecesse regras de segurança, como a presença permanente de pessoas no local. 
onde não há via de acesso por terra, só pelo Rio Alto Juruá ${ }^{208}$. Por isso, o uso desses equipamentos está condicionado ao trabalho dos professores indígenas e daqueles que são aptos a manuseá-los. Além desses, em geral os Ashaninka que os utilizam são aqueles que estão envolvidos em atividades da Asssociação e da Cooperativa. Parece-me bastante evidente que essa forma de interagir com 0 mundo digital está condicionada às especificidades da organização política Ashaninka e à preocupação deles de manter forte suas referências culturais tradicionais $^{209}$. Ou seja, eles elaboram a inserção deles nas redes digitais, bem como seu modo de interagir nos fluxos globais de informação.

\subsection{TRÍADE SIMBIÔNTICA ASHANINKA}

A face visível da rede nas arquiteturas digitais indica a digitalização como ecossistema informativo reticular transformador do lugar físico onde vivem e se reproduzem simbolicamente essas culturas, além de indicar também a digitalização informativa de suas memórias (ao registrarem suas histórias, músicas e narrativas) e de suas ações de sustentabilidade (como apresentado no vídeo "A gente luta mas come fruta"). Mais que um instrumento, as tecnologias de informação e comunicação em interação com esses povos tornam-se um vetor de enunciação e experimentação de linguagens e performatividades, isto é, um novo modo de habitar, associado a essas tecnologias.

Formado por um coletivo de tecno-atores, humanos e não humanos, as interações com essas tecnologias digitais ampliam os agenciamentos e as ações por eles realizados. Ao longo desta parte, composta por este subitem e pelo anterior, vimos a composição e as relações reticulares da Rede Povos da Floresta em torno

${ }^{208}$ Marechal Thaumaturgo é um dos municípios mais isolados do Acre. Sua população urbana e rural é de 14.200 habitantes (IBGE, 2010), distribuídos em $8.192 \mathrm{~km}^{2}$. Saindo de Cruzeiro do Sul (cidade mais próxima com um aeroporto) em um avião de pequeno porte são aproximadamente cinquenta minutos e de barco pequeno são dez horas de viagem. Com barcos maiores são dois dias de viagem, dependendo dos períodos de cheia do Juruá e de sua direção (descer ou subir).

209 Em conversa com Benki, ele disse que o acesso à rede, para os Ashaninka, tem um "propósito". Ao mencionar que tiveram energia elétrica na Aldeia em certo momento, contou que cada família passou a ter som e TV, mas eles perceberam que elas estavam deixando de ouvir as histórias dos mais velhos para ficarem diante dela. Houve um momento de grande inquietação entre eles e assim, por consenso, decidiram não ter mais energia elétrica. Essa preocupação veio, principalmente, em decorrência de uma possível interferência na língua Ashaninka. 
da implantanção, principalmente, dos trinta Pontos de Cultura. Vimos também as associações realizadas em torno dos projetos de sustentabilidade dos Ashaninka. Além deles e dos membros da RPF, as organizações governamentais e não governamentais compuseram essa rede descentralizada, essa rede de redes. De seus atores não humanos, além da própria Floresta como grande ecossistema, destacam-se os rios (Alto Juruá, Moa, Amônia, Tejo), toda a fauna e a flora (espécies nativas e frutíferas).

Exemplos triviais nos dão a dimensão da reticularidade e agencialidade da Floresta. De fato, como as redes, a Floresta é um ecossistema altamente complexo que extrapola a narração de suas partes, da sua fauna, flora e espíritos. É preciso senti-la. Diferente de toda a tradição do pensamento ocidental que construiu representações sobre a Natureza, externalizando-a para dominá-la, quando se está na Floresta, a sentimos de modo pleno. Com os dispositivos técnicos de conexão interligando essas comunidades cumpre-se seu destino de conexão com os diversos planos. Essa conectividade parece residir, de alguma forma, em um imaginário fantástico ecológico performatizado em várias produções audiovisuais, a mais recente Avatar, de James Cameron (2009) $)^{210}$, as aventuras dos Navis e seus híbridos, unidos pela salvação do seu planeta. Contudo, da Floresta, embora tenha sido "imaginada" ora como paraíso, Eldorado e inferno, emana um grande mistério, somos impelidos à diminuição de qualquer ímpeto de supremacia humana. Assim, nada mais pós-humano que a Floresta.

Obviamente não são todos que ultrapassam essas fronteiras corpóreas. Esse trânsito entre os diversos planos é realizado, sobretudo, pelos xamãs, mediadores natos desses ecossistemas. A agencialidade não é só do xamã, mas também das ervas para a ayahuasca. Essa ritualização Ashaninka esteve presente em todos os momentos de troca e de encontros com outras redes. Por exemplo, os encontros com os agentes da Rede, sejam eles autoridades políticas e/ou institucionais, realizados no Centro Yorenka Ãtame ou na Aldeia Apiwtxa, eram celebrados com piyarentsi (bebida fermentada da mandioca) e kamarampi (Ayahuasca) ${ }^{211}$.

${ }^{210}$ Narrativa pós-humana e pós-humanista, Avatar reuniu os elementos de vanguarda em 3D, transformando-se um filme paradigmático no gênero, com um forte apelo ecológico. Seu diretor, James Cameron, participou de manifestações no Brasil contra a construção da Hidrelétrica de Belo Monte.

${ }^{211}$ Em minha primeira noite em Marechal Thaumaturgo, após chegar ao Centro Yorenka Ãtame, participei, a convite de Benki, de um ritual da Ayahuasca realizado por ele com a participação de sua família e dos jovens do Yorenka Ãtame. Mesmo não sendo Ashaninka, muitos desses jovens 
Tais rituais, em pleno funcionamento na estrutura social da comunidade Apiwtxa, demonstram a força cultural desse povo (LESSIN, 2011) ${ }^{212}$, significando a força da sua ecologia política xamânica. Também o ayonpari, seu sistema de troca tradicional, foi ressignificado nos "tempos dos projetos" e das redes digitais. São índices de uma indigenização do próprio projeto moderno, como dito por Marshal Sahlins (2007, p. 545-546), em que essas populações se apropriam do termo "cultura", objetivando-o e remodelando-o de acordo com suas especificidades culturais para utilizá-las no campo da atuação interétnica:

O que a consciência da "cultura" significa de fato é a demanda desses povos por seu espaço próprio na ordem cultural mundial. Em lugar de uma recusa das mercadorias e das relações o sistema mundial, isso significa mais frequentemente aquilo que os encantaram: um desejo de indigenizá-las. O projeto é a indigenização da modernidade.

As práticas rituais formam agenciamentos e relações com outros planos, sejam eles míticos, xamânicos, uma disposição reticular presente na cosmologia Ashaninka e na história da sua política interétnica, criadoras de redes de alianças e de formas comunicativas de habitar corporificadas também nas paisagens midiáticas digitais (mediascapes), principalmente da música e do audiovisual. Forma-se um conjunto de imbricações culturais e territoriais e, sem as mídias digitais, não haveria a potencialização do seu movimento reticular, sua expansão para outras localidades e, por sua vez, o fortalecimento dos projetos desses coletivos.

Esse conjunto tem igualmente uma incidência estética, as roupas Ashaninka, a kusma; as pinturas corporais e as pinturas em quadros remetem ao imaginário xamânico da floresta, seus elementos, a jiboia (yakuruna ${ }^{213}$ ), os rios, a flora, os

estava vestidos, para aquela ocasião, com as kusmas e os colares Ashaninka, prova de uma indigenização ritualística. Após a ingestão do chá, todos sentados concentrados em um longo momento de silêncio pareciam estabelecer, cada um a seu modo, a conexão com a Força (nome dado ao efeito psíquico e cósmico do chá). Em seguida, Benki proferiu um ritual de cura a uma mulher Ashaninka. Depois, falou sobre o propósito dessa "conexão" com a natureza pela Ayahuasca e ressaltou o trabalho que vem realizando com a comunidade. Na ocasião, me apresentei a todos e comentei sobre a minha pesquisa, expressando a disposição em assessorálos em um projeto de apoio para as atividades realizadas com os sistemas agroflorestais. Em seguida, muita cantoria com voz e violão, com canções em reverência à Floresta e à Ayahuasca. Benki gravou várias dessas canções em que ele canta e toca violão.

212 Lessin (2011) descreve ambos rituais, seu preparo e beberagem, como formas de desenvolvimento das relações políticas internas (reciclagem da identidade primordial) e externas (reciclagem da sustentabilidade cosmológica).

213 Yakuruna é um termo Ashaninka para a jiboia mítica, representada na cosmologia Ashaninka como um espírito de poder (Depoimento de Benki Pianko à LESSIN, 2011, p. 9). 
próprios Ashaninka, todos pertencentes a uma paisagem viva em movimento, em seus diversos planos de virtualização e atualização (xamânica e digital).

Interpreto, portanto, essa ecologia xamânica comunicativa Ashaninka, essa forma de atuação de um perspectivismo Ashaninka, como uma rede de redes, em que o mito e o xamanismo são referenciais edificantes de um plano simbólico e político, em que a simetria entre humanos e não humanos, nos termos de Latour, constitui esse coletivo, sem a contraposição ontológica entre Natureza e Sociedade. Tais categorias produzidas pelas sociedades ameríndias da Amazônia, como vimos anteriormente, são significadas diferentemente. No xamanismo, alguns indivíduos tem a habilidade de transitar nos diversos planos corpóreos, respondendo a um tipo de multinaturalismo, entrando no mundo das diversas naturezas e perspectivas dessa humanidade compartilhada.

O próprio sistema de troca tradicional, reatualizado na atuação deles em projetos sustentáveis, compõe essa ecologia Ashaninka. Suas redes, suas trocas, bem como seus territórios, foram ampliados pela digitalização, mas não só eles. Esse saber tradicional profundamente consorciado com a Natureza, sua territorialidade, possui um valor global a ser compartilhado entre todos, capaz de transformar a visão sobre essa mesma Natureza, conforme essas significativas palavras de Benki Pianko sobre o papel do Centro Yorenka Ãtame:

O que a gente vive ou cria pra sociedade, de uma forma geral, é uma transformação da visão de pensamento sobre a natureza. Então, o Centro Yoreñka Atãme foi uma criação pensada de: "e se a gente puder criar novos mecanismos para desenvolver as nossas tecnologias, que essa sabedoria possa vir agregada ao valor tradicional e esse valor venha a dar um suporte ou dar um valor maior ao que a natureza tem? Nós podemos estar criando pra sociedade um novo pacto em que a nossa maior riqueza, nossa maior contribuição, que hoje a gente tem pra dar está dentro da visão do que a gente tem do valor de tudo da floresta aqui, ou, em outros níveis, até global, né?

Como é que nós não vamos viver sem a água, como nós não vamos viver sem o ar? Nós não vamos viver sem as florestas, nós não vamos viver sem a terra. (BENKI apud LESSIN, 2011, p. 143)

Essa consciência da contribuição deles para a sociedade, pautada por um novo pacto ecológico reticular com seu território e seus saberes, se reforça e se amplia com a digitalização, com as interações e com as novas tecnologias de informação e comunicação. 
As tecnologias de comunicação nos fornecem uma percepção particular do ambiente, criando práticas interativas em consequência de seu papel ativo, constituindo uma experiência habitativa característica. É possível, portanto, após o advento das redes digitais, pensarmos em uma nova ecologia capaz de criar um dinamismo interativo entre esses elementos digitalizados, típica de uma forma comunicativa do habitar distinta daquela expressa pelos meios de comunicação analógicos (Di Felice, 2009). (DI FELICE, TORRES, YANAZE, 2012, p. 208)

Em outro momento, chamei essa atuação não só dos Ashaninka, como dos da Rede Povos da Floresta, como net-ativismo ecossistêmico:

\begin{abstract}
Essas conexões inauguradas pelas dinâmicas da Rede Povos da Floresta parecem, assim, apontar para uma ação colaborativa em rede - entre as comunidades tradicionais - e na rede digital - com interação desses povos com as arquiteturas digitais de informação -, para aquilo que chamamos de "net-ativismo ecossistêmico", onde a ação na rede pressupõe as suas partes interagentes: as comunidades tradicionais (com os seus saberes locais), o ambiente e os fluxos comunicativos. É uma ação integrada, aberta às relações entre as suas partes pelas quais também formam esse ecossistema informativo. (PEREIRA, 2010, 12)
\end{abstract}

Certamente, a interação da cultura Ashaninka com as redes digitais está intrinsecamente associada a sua territorialidade, fortemente geográfica e simbólica (xamanica), como mencionado por Ailton Krenak na epígrafe do capítulo anterior, novamente aqui reproduzida:

A territorialidade é o que sustenta suas redes de relações apoiadas na reciprocidade e ajuda mútua. Quando se rompe essas condições e essa rede de relação social, cultural e simbólica tem-se a erosão cultural. Indicadores dessa erosão são os altos índices de carência (carência de relações, carência de identidade, carência de símbolos, carência de afeto entre as pessoas) levando alguns à loucura, inclusive ao suicídio e à morte por fome.

Essa rede de relações existe naturalmente em algumas de nossas comunidades. E é assim que estas comunidades tem se mantido por décadas de geração a geração.

Nas últimas décadas, têm surgido redes de indivíduos e grupos de pessoas ativas na defesa dessa territorialidade. São pessoas ligadas a demandas destas comunidades tradicionais, apoiadores e parceiros de diferentes iniciativas locais.

Para estes parceiros a proteção do meio ambiente e dos valores que mantêm estas comunidades seguras de sua identidade e autonomia são a garantia de qualidade de vida e futuro melhor para todos. 
Todos estes símbolos criativos e afirmativos da identidade local e regional, que encontram eco nesses grupos de apoio, refletem como aquele ambiente ou lugar.

Uma função da Rede Povos da Floresta é alimentar o fluxo entre estas comunidades de informação e grupos de apoio e solidariedade a ponto de não deixar nenhum furo nessa rede. Canal franco, aberto, para intercâmbio. Via de trânsito rápido e de mão dupla.

A Rede Povos da Floresta é uma iniciativa voltada para o fortalecimento institucional das ações de todas essas comunidades diante da pressão enorme que sofrem para saírem de seus territórios de origem. (Krenak, RPF, 2003) $)^{214}$

Essa concepção territorial reticular fortemente ligada ao lugar, ao ecossistema da Floresta, é uma especificidade desse local digital das culturas. Nesse sentido, a conexão dessas comunidades, por meio da digitalização, somada à valorização de suas culturas e de seus territórios (físicos e simbólicos), fortalece esses repertórios socioculturais. Esse ecossistema relacional, interagente e informativo transcende a determinação de um único fator emergente:

Uma vez reproduzido digitalmente o espaço, transformado o mesmo em informação, configura-se a formação de um habitar informativo, pós-arquitetônico e pós-geográfico que, multiplicando os significados e as práticas de interações com o ambiente, nos conduz a habitar naturezas diferentes e mundos no interior dos quais nos deslocamos informaticamente. (DI FELICE, 2009, p. 22)

Essa metaterritorialidade reticular, acionada por essas espacialidades comunicativas, feita de trocas informativas, não só alteram seus territórios físicos e simbólicos como apontam para a emergência habitativa atópica, capaz de proporcionar uma forma reticular de interação entre o território, a biodiversidade e as culturais locais. No caso dos Ashaninkas e dos Povos da Floresta, isso pode significar também, além da disseminação de seus saberes tradicionais baseados em sua relação sustentável com a natureza, a visibilidade de sua diferença e a promoção de ações em rede entre essas comunidades e na rede pelos circuitos digitais. Deslocam a Floresta e seus povos para o mundo, possibilitando a transmissão de sua atmosfera ambiental e o diálogo intercultural com outras redes de apoio além das historicamente existentes. Essa tríade simbiôntica (culturas, mídias digitais, territórios) interpendente retroalimenta-se, formando um tipo de

${ }^{214}$ Único post do site da Rede Povos da Floresta assinado por Ailton Krenak, disponível em: http://redepovosdafloresta.org.br/exibePagina.aspx?pag=45\&pagTipo=h. Acesso em: $12 \mathrm{dez}$. 2003. 
complexidade recursiva, dialógica, hologramática (MORIN, 2001) e atópica (DI FELICE, 2009), como mostrado no mapa a seguir: 


\section{PARTE III}

O Portal Kabyle.com e a e-diáspora cabila 
[...] mobilité et connectivité forment désormais un ensemble de base dans la définition du migrant du XXI siècle. Ensemble ils agissent comme un vecteur qui assure et conduit les lignes de continuité dans la vie de migrants et dans les rapports que ceux-ci entretient avec leur environnement d'origine, d'accueil ou parcouru. Hier : immigrer et couper les racines ; aujourd'hui : circuler et garder le contact. Cette évolution semble marquer un nouvel âge dans l'histoire des migrations.

Dana Diminescu (2010, p. 53)

Une fois sur Kabyle.com nous sommes dans le village global kabyle.

Stephane Arrami (2012) ${ }^{215}$.

Nesta terceira parte chegamos à outra expressão do local digital das culturas decorrente dos processos e-diaspóricos da rede dos cabilas, originários dos povos Imazighen (berberes) do norte da Argélia. Apresento, portanto, as especificidades da diáspora cabila que, ao contrário da Rede Povos da Floresta e dos Ashaninka, não habitam um território geográfico originário, nem uma única localidade específica, mas as redes digitais que os conectam com suas memórias, suas bases referenciais de identidades culturais, engendrando, assim, uma "rede de redes" que reúne identidades, informações, tecnologias.

Veremos, aqui, como os deslocamentos e os processos diaspóricos pertencentes aos processos globais e transnacionais atuais disseminam as diferenças culturais intrinsecamente coadunadas com as tecnologias de informação e comunicação. Se o próprio processo de identificação e de produção de subjetividade depende das tecnologias comunicativas (LEVY, 2002) e de seus agenciamentos maquínicos (DELEUZE e GUATTARI, 1995), os laços familiares, comunitários e afetivos nas diásporas se tornam um grande expoente da equação: comunidades transnacionais = diásporas+tecnologias digitais (DIMINESCU, 2010). Isto é, o local digital das culturas diaspóricas tem no oximoro: "local digital" a sua máxima expressão, em que o processo de digitalização, por meio de suas interações, 'conecta' suas origens inventando uma metaterritorialidade meta-tecnocultural que delineia as espacialidades comunicativas reticulares de grupos em situação de diáspora.

${ }^{215}$ Stephane Arrami é desenvolvedor e editor do portal Kabyle.com, a arquitetura informativa digital mais importante da diáspora cabila. Tal trecho decorre da entrevista realizada por e-mail (data de envio das perguntas: 27 de julho de 2012). 
Seguindo a perspectiva reticular de análise para refletirmos sobre as nuances dessa nova condição dos grupos migratórios sob a chave teórica da tríade simbiôntica e das formas comunicativas do habitar, selecionei o caso da diáspora cabila, focalizando principalmente sua migração na França, dada a situação colonial e pós-colonial vivida por esse grupo nesse país. Ao analisar os meandros dessa experiência, dividi esta parte em dois capítulos, o quinto e o sexto capítulos, seguindo a numeração precedente.

No quinto capítulo, apresento ao leitor brasileiro quem são os povos cabilas, quantos são e onde estão localizados, explicando as especificidades "apolita"216 desse povo de origem berbere, pertencentes as povos do Magrebe, do norte da África. Na oportunidade, comento algumas das características da sua identidade cultural, do seu aspecto religioso sincrético, seu "islamismo laico" e sua tradição oral. Em seguida, analiso os principais dados históricos, a colonização francesa, a guerra pela independência e a pós-colonização como fatores condicionantes da diáspora cabila.

No sexto capítulo, percorro a "e-diáspora", a fase digital e 'conectada' da diáspora cabila, partindo para a interação, observação e descrição do principal, senão o mais importante, portal da diáspora cabila no mundo, o Kabyle.com. Na última parte, encerro novamente com a interpretação do significado dessa digitalização, referindo-me à tríade simbiôntica, caracterizada, nesta experiência, pela primazia das arquiteturas informativas digitais na perfomatização da identidade cabila e na constituição de um espaço comunicativo digital e transnacional onde a cultura não se encontra em seu território de origem, nem numa geografia específica, mas se reúne e se reproduz nos fluxos comunicativos.

$\overline{{ }^{216} \text { Do grego "a-polis", sem cidade. }}$ 


\section{IMAZIGHEN E CABILAS}

\begin{tabular}{|c|c|}
\hline Vava Inouva & Pai Inouva \\
\hline Txilek elli yi n taburt a Vava Inouva & Eu oro para que meu pai Inouva abra a porta para \\
\hline Ccencen tizebgatin-im a yelli Ghriba & mim \\
\hline Ugadegh Iwahc elghaba a Vava Inouva & A filha Ghriba tilinta suas pulseiras \\
\hline Ugadegh ula d nekkini a yelli Ghriba & $\begin{array}{l}\text { Eu temo pelo ogro da floresta, pai Inouba } \\
\text { A filha Ghriba teme também. }\end{array}$ \\
\hline Amghar yedel deg wbernus & \\
\hline Di tesga la yezzizin & $\begin{array}{r}\text { O velho envolto com seu albornoz } \\
\text { Fora se aquece }\end{array}$ \\
\hline Tislit zdeffir uzetta & {$[\ldots]$} \\
\hline Tessallay tijebbadin & A filha atrás do tear \\
\hline Arrac ezzin $d i$ tamghart & Sem cessar com os tensores \\
\hline A sen teghar tiqdimin & $\begin{array}{l}\text { Crianças em torno do velho } \\
\text { Educando-os com as coisas de antigamente }\end{array}$ \\
\hline $\begin{array}{r}{[\ldots]} \\
\text { Adfel vessed tibbura }\end{array}$ & \\
\hline$[\ldots]$ & A neve se amontoava contra a porta \\
\hline Tajmaât tettsargu tafsut & \\
\hline$[\ldots]$ & O tajmaât [assembléia] já sonha a primavera \\
\hline $\begin{array}{l}\text { Idegger akken idenyen } \\
\text { Mlalen d aït waxxam }\end{array}$ & O tronco de carvalho substitui as prateleiras \\
\hline I tmacahut ad slen ${ }^{217}$ & A família reunida \\
\hline Idir, 1996 & Ouve o conto \\
\hline
\end{tabular}

Dos circuitos da Rede Povos da Floresta aos Ashnainka da Amazônia acreana, as redes digitais me levaram até a França. Atravessei o Atlântico e o Mediterrâneo no rastro da e-diáspora cabila. Em virtude das especificidades desse povo, apresento, neste capítulo, um preâmbulo sobre a cultura cabila, alguns dados sobre sua origem, sua vinculação com a cultura Amazigh (berbere), a religiosidade, a organização política tradicional e sua rica tradição oral. Analiso, também, a história da colonização francesa na região, a luta pela independência, a pós-colonização e a

${ }^{217}$ Este poema em tamazigh (língua berbere) é a letra da famosa canção "Vava Inouva", composta por Idir, músico franco-cabila, baseada em um conto popular berbere, cabila, sobre a história de "Vava Inouva", um velho, morador da floresta, que reconhece sua filha pelo barulho de suas pulseiras. Existem inúmeras interpretações sobre esse conto. O poema mostra, ainda, a importância dos contos e dos mitos narrados pelos mais velhos, formando os elos entre gerações, a base da cultura cabila. Minha tradução para o português baseou-se na versão francesa anexa (ver Anexo 4). 
diáspora cabila na França, um quadro histórico pulsante transcorrido por rupturas e decontinuidades.

\subsection{IMAZIGHEN E CABILAS ${ }^{218}$}

A Cabília, situada na região montanhosa ao norte da Argélia, constitui a referência geográfica de proveniência dos povos cabilas, originários dos Imazighen (povos "berberes" no plural, Amazigh, no singular), que significa, nessa língua, "homens livres". Localiza-se entre a capital argelina, Argel, e a cidade de Constantina; ao norte, limita-se com o mediterrâneo; ao sul, com as altas planícies argelinas. É uma região densamente povoada, onde seus habitantes falam a língua berbere (tamazight) com sua variação dialetal (taqbaylit), além do árabe e do francês. Atualmente, sua população total é de 5.500 .000 habitantes, vivendo 3.500.000 deles na Argélia, um milhão na França e o restante em outras partes do mundo, principalmente no Canadá.

${ }^{218}$ Para a composição desta parte histórica e etnológica dos povos Amazigh (berbere) e cabilas me apoio, sobretudo, nos trabalhos da etnóloga Camille Lacoste-Dujardin, pesquisadora do Centre national de la recherche scientifique - CNRS (França). Lacoste-Dujardin é a mais destacada pesquisadora de cultura cabila na França. Seus trabalhos principais referidos nesta tese são: Dictionnaire de la culture berbere em Kabylie. Paris: La Decouverte, 2005; e «Un effet Du "postcolonial": Le renouveau de la culture kabyle. De la mise à profit de contradictions coloniales». In: Hérodote, Paris, v. 1, n. 120, p. 96-117, 2006. Igualmente, consultei dois trabalhos da historiadora argelina radicada na França, Karima Direche-Slimani: Histoire de l'immigration kabyle en France au XXe siècle. Paris: L'Harmattan, 1997 [sua tese de doutorado]; e «Le mouvement des âarch en Algérie: pour une alternative démocratique autonome?», Revue des mondes musulmans et de la Méditerranée [En ligne], 111-112 |mars 2006. Trabalhos de outros pesquisadores, inclusive cabilas, foram considerados na composição deste capítulo, entre eles, do sociólogo Abdelmalek Sayad, entre outros. Sayad colaborou frequentemente com Pierre Bourdieu, ajudando-o em sua pesquisa de campo na Cabília (1959-1960). Bourdieu estudou a cultura cabila construindo seus principais conceitos, dentre eles o de campo e habitus, entre outros; presente em suas principais obras: Les sens pratique (1980) e La domination masculine (1998). 


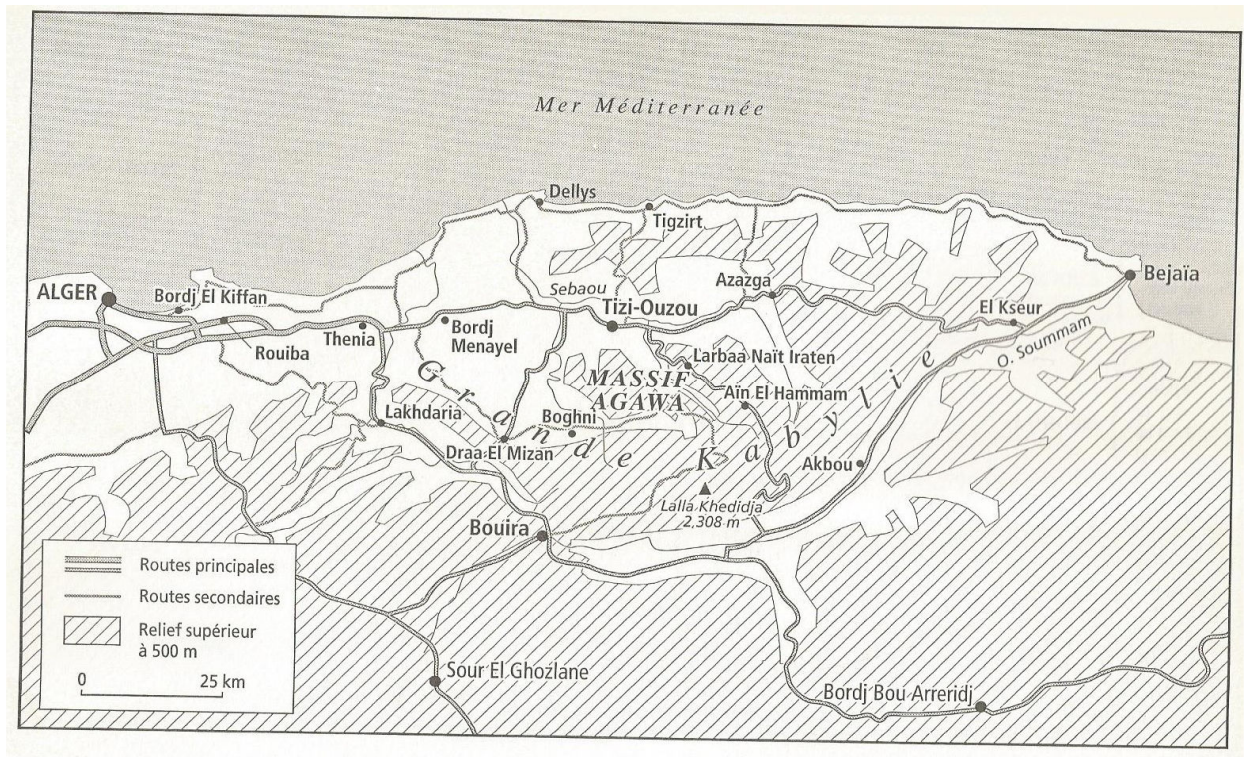

Figura 10 - Mapa da Grande Cabília (Argélia). Fonte: Lacoste-Dujardin, 2005, p.8.

De fato, mais que 'a' Cabília, deve-se considerar 'as' Cabílias, no plural, já que os geógrafos reconhecem uma Cabília de Djudjura (ou Grande Cabília), a maior, a mais alta e mais populosa; também a Cabília de Bibans, no sul do rio Soummam; e outra Cabília, a dos Babors, a leste e ao longo da costa, que devem ser adicionadas ao massivo de montanhas de Guergour sobre o lado direito do rio Soummam; e, por fim, a Cabília de Collo (LACOSTE-DUJARDIN, 2005).

Essa diversidade geográfica é também refletida na língua tamazight (berbere) falada nas Cabílias. Na Cabília de Djudjura é nitidamente menos arabizada que as outras Cabílias, onde se constata frequentemente uma forma de bilinguismo árabecabila (LACOSTE-DUJARDIN, 2005, p. 202).

Essa divisão "Grande Cabília" (Cabília de Djudjura) e "Pequenas Cabílias" (Cabília de Bibans, Babors, Collo) é uma distinção oriunda da antiga divisão administrativa herdeira dos departamentos da Argélia Colonial. De fato, a Cabília de Djudjura é uma montanha melhor individualizada por suas características também populacionais, em termos de densidade e povoamento, com forte personalidade cultural e política. Foi dessa região que emigrou a maior população Cabila, sobretudo para a França.

A denominação "Cabila" foi designada pelos árabes mulçumanos para referirse às inúmeras tribos da região, pertencentes ao grande grupo linguístico Amazigh (berbere). De fato, para se compreender as especificidades culturais dos povos Cabilas e seu processo migratório, devemos situá-los dentro desse grande grupo 
linguístico, um dos mais antigos da região do Magrebe, que compreende o noreste da África, incluindo Marrocos, Sahara Ocidental, Argélia, Tunísia, Mauritânia e Líbia.

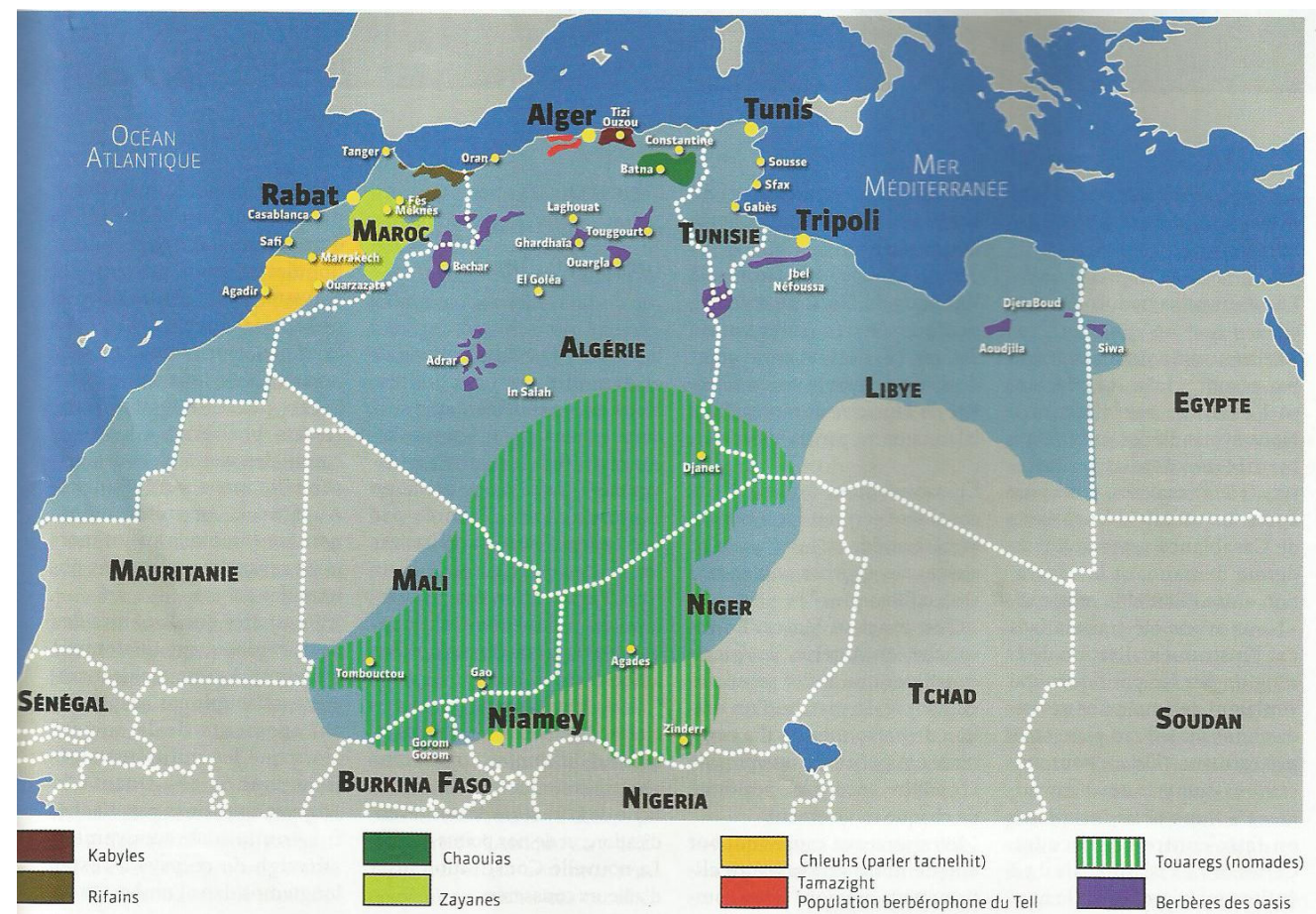

Figura 11 - Mapa das populações berberes na região do Magrebe. Fonte: Le courrier L'Atlas, 2012, p. 62

Embora os números sejam controversos, estima-se que sejam aproxidamente 45 milhões de falantes da língua berbere com suas variantes dialetais. Destes, 35 a $40 \%$ são marroquinos, sendo, desse universo, quinze a dezesseis milhões são falantes chleuhs, rifains. Na Argélia, eles seriam aproxidamente dez a doze milhões entre cabilas (os mais numerosos), chaouias, mozabites, chenouis e touaregs. Além disso, há dez mil siwis no Egito, os guanches das llhas Canárias, os amazighs da Líbia, Tunísia, os touaregs que povoam o Níger, Mali, Burkina Faso e Nigéria, incluindo os dez mil Zenagas da Mauritânea (SOFIANE, 2012). Mesmo dispersa em muitos dialetos, distinta da língua árabe, a língua berbere apresenta uma real unidade gramatical (possui fonética, estrutura e sintaxe próprias), reivindicada por vários movimentos associados a esses grupos. Na Argélia, como resultado do movimento berberista (berberisme) na região das Cabília, o governo oficializou, em 2003, a língua tamazight (berbere), ao lado da língua árabe, como línguas nacionais.

Cette langue, quoique sans doute attesté dans d'antiques inscriptions gravées, dites libyques, est restée depuis alors orale, et le berbère ne s'écrit guère aujourd'hui. Seuls les Touaregs ont conservé une 
écriture, le tifinagh, qu'ils n'emploient qu'à des jeux éphémères ou des graffitis, sur le sable ou les rochers, et qui, écrit selon différents alphabets, n'a été d'usage ni commercial, ni de pouvoir. Cependant, quelques publications l'emploient aujourd'hui. Alors que les Berbères marocains ont parfois écrit en caractères arabes, on écrit plus souvent taqbaylit (le kabyle) en caractères latins. Ainsi peut-on désormais conserver et transmettre a la très riche littérature orale kabyle, et plus généralement berbère, en prose - contes, légendes, mythes, histoires plaisantes - comme vers - poèmes amourex, chantés et, aujord'hui, théâtre ou films. (LACOSTE-DUJARDIN, 2005, p. 66)

De fato, ao lado desse núcleo linguístico, e de suas variações, transmitido oralmente entre gerações pelos contos populares, lendas, mitos, músicas, etc., há a arte e o artesanato material, ricamente decorado, a tecelagem, artes em couro, cerâmica, joias, sem contar a arquitetura (a casa cabila ${ }^{219}$ ). Na Cabília, da cultura material berbere se destacam o albornoz (abernus) e a colher de madeira

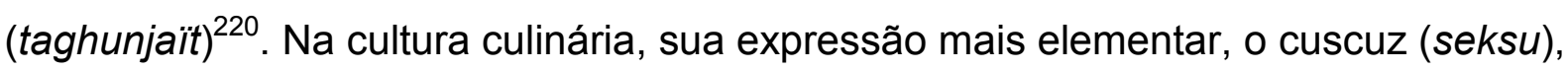
tornou-se um prato culinário internacionalmente conhecido (LACOSTE-DUJARDIN, 2005). Todos esses elementos característicos dão certa sustancialidade a uma identidade berbere dos cabilas.

Quanto às origens desses povos, elas são tão remotas e imprecisas quanto as religiões ali existentes. Os vestígios de sua presença remontam entre 10.000 a 5.000 a.C. A participação desses povos berberes nos principais impérios, ora como atores dinâmicos, ora resistindo a eles, marcou a história desses grupos. A região da Cabília foi ocupada pelos gregos, fenícios e romanos. A origem da palabra "berbere" tem relação com "bárbaro", palavra latina que os antigos romanos utilizavam para nomear as populações que não habitavam o Império, do latim barbarus, derivado do grego antigo (não grego ou estrangeiro).

Em uma perspectiva de longa duração, compuseram um rico e complexo quadro de misturas, assimilações e resistências.

\footnotetext{
${ }^{219}$ Pierre Bourdieu produziu um famoso ensaio sobre a casa cabila, publicado no Brasil sob o título: "A casa ou o mundo às avessas". In: CORREA, M.; Silva, M. (Orgs). Ensaios sobre a África do Norte. Campinas, SP: Unicamp, 2002. Baseado em sua pesquisa etnográfica na região da Cabília, Bourdieu refere-se à organização simbólica do espaço, às relações de parentesco e às práticas da comensalidade. Lacoste-Dujardin comenta que, embora a obra apresente um modelo bastante sedutor da 'casa cabila' das relações que ali se desenvolvem, a etnóloga critica o fato de esse modelo "contradizer a própria realidade". Sua crítica contesta a descrição e as referências a um arcaísmo cabila descrito e reforçado por Bourdieu.

${ }^{220}$ Antes da sua ocupação (VII d.C.), esse objeto era desconhecido pelos árabes, que comiam com as mãos.
} 
Les Berberes ont été dês acteurs dynamiques de l'histoire du Maghreb, illustrée par leurs grans empires de "l'âge d'or»: celui des Almoravides sahariens a contrôlé les routes de l'or et, au Xle siècle, s'est étendu du Maroc jusqu'à Bejaïa, puis celui des Almohades, aux XIle et XIIle siècles, a unifié tout le Maghreb, du Maroc jusqu'en Tripolitaine. Les Berbères sont aussi distingués par leur contante et âpre résistance aux dominations étrangères qui se sont succédé au Maghreb: Carthaginois, Romains, Vandales, Byzantins, Arabes, Turcs, Français. Ils eurent leurs héros: entre autres, Tacfarinas, Firmus et son frère Gildon, qui s'opposèrent aux Romains ou à leurs alliés. Ils eurent aussi, toujours contemporains des Romains, leurs grands rois: Massinissa (203-148 av. J.-C.), roi dês Massyles, Jugurtha (160-104 av. J.-C), Juba I (50-46 av. J.-C.) et Juba II (25 av. J. -C.-24 ap. J.-C.), puis la célèbre Kahina de l'Aurès qui, avant d'être vaincue, resista aux Árabes; ils eurent aussi de grands penseurs comme Saint Augustin, dont la mère Monique aurait été berbère. L'esprit d'independence a toujours été si fort parmi eux que, lorsqu'ils adoptèrent des versions héretiques à tendance égalitariste, comme le donatisme du christianisme byzantin, le kharidjisme ou ibadisme (au Mzab et à Djerba), voire le chiisme fatimide, pour l'islam. (LACOSTE-DUJARDIN, 2005, p. 67)

Dessa incursão de povos, o saldo para a cultura cabila são expressões muito próprias da religião, da sua organização política social e de toda a sua tradição oral e literária.

\subsubsection{Islã, laicidade e organização política local}

Os cabilas foram 'islamizados'221 pelos marabutos ${ }^{222}$, eremitas e santos locais, que não participavam ativamente da organização política local. Por essa

${ }^{221} \mathrm{O}$ islã é a religião dominante entre os cabilas, mas existe um pequeno percentual da população cristã e judia. Os judeus argelinos, notavelmente conhecidos, receberam a nacionalidade francesa em 1870. Após a independência, se juntaram aos outros colonos franceses, deixando o país. Cerca de 150.000 foram repatriados na França.

222 Esses eremitas marabutos eram personalidades reverenciadas por sua sabedoria, por seus poderes ocultos e por fabricarem amuletos. As pessoas buscam sua assistência nos momentos mais importantes de suas vidas: casamento, morte ou qualquer ocasião solene (LACOSTEDUJARDIN, 2005). Além dos marabutos, na Cabília existia o amusaw/imusnawen, sábio local detentor das tradições orais. Numa conversa com Pierre Bourdieu, o antropólogo franco-argelinocabila Mouloud Mammeri comenta a diferença entre o marabuto e o amusaw: "O amusnaw é um perito no caráter cabila em todos os aspectos: social, moral, psicológico. Já o marabuto é, antes de mais nada, o intérprete do Corão e dos comentários do Corão, do direito corânico. O marabuto é marabuto de nascença; o amusnaw é amusnaw por seleção, é obrigado a assumir uma série de valores, de técnicas, para se tornar amusnaw. O marabuto não tem escolha, é filho de seu pai, deve simplesmente representar o direito. Ele pode acumular as duas funções: existem muitos marabutos que são imusnawen. É raro que o amusnaw tenha feito os estudos em árabe. E os 
característica, os cabilas conseguiram manter a separação entre sua organização social e a religião islâmica. Suas organizações sociais eram descentralizadas, cada vilarejo possuia um âarch (conselho tribal), formado pelos homens mais destacados de cada família (clã), que se reuniam na tajmaat ${ }^{223}$ (sala de reuniões).

Tal estrutura política tinha em seus princípios aspectos democráticos de participação direta dos seus pares nas decisões locais, aspecto sublinhado em toda bibliografia lida específica sobre o assunto (LACOSTE-DUJARDIN, 2005, 2006; DIRECHE-SLIMANI, 2006; PLANTADE, 2007) e reforçado nos conteúdos divulgados nos sites cabilas e nas entrevistas realizadas. Lacoste Dujardin (2005) classifica a sociedade antiga cabila formada por uma forma "original de democracia" com viés "igualitarista", que manifesta um islã popular mais tolerante:

Ce peuple vit em une société organisée autrefois selon une forme originale de démocratie, une société segmentaire dont demeurent les représentations. Ses membres ont en commum des institutions, des coutumes, des usages particuliers et ils partagent un même idéal égalitariste. Ils expriment leur attachement à un même islam populaire, tolérant le culte des saints, et dans une fidélité à certains rituels, croyances ou mythes plus anciens. (LACOSTE-DUJARDIN, 2005, p. 10)

As instituições políticas tradicionais cabilas geriam a vida cotidiana da comunidade diante de situações práticas, separando suas decisões das leis estabelecidas pelo Alcorão, como comenta o cientista político Yidir Plantade (2007, p. 86):

Le rôle de l'assemblée du village est une autre illustration de la protolaïcité endogène de la société kabyle. Cette institution, la tajmaat, rassemble les hommes adultes du village afin de gérer en commun les affaires publiques. Dirigée en pratique par les doyens des grandes familles--les jeunes n'ont quasiment pas voix au chapitre--la tajmaat constitue un remarquable espace de débat laïc sur les affaires de la Cité. Certes, le président de séance ouvre et ferme celle-ci par un bref verset du Coran, mais ceci n'est guère différent du serment sur la Bible que prêtent les présidents américains. Les discussions de la tajmaat concernent la gestion réelle et concrète des affaires du village et ne dévient pratiquement jamais dans le domaine théologique. Cette séparation souple mais effective du temporel et du

estudos não eram feitos em árabe porque não é a mesma lógica." (SAYAD e BOURDIEU, 2006, p. $57)$.

${ }^{223}$ Tomo essa referência dos estudos de Camille Lacoste-Dujardin (2005), embora alguns autores, como o cientista político Yidir Plantade, refiram-se a esse conselho ou assembleia de tajmaat, que Lacoste-Dujardin chama de âarch (seguida pela historiadora Direche-Slimani). 
spirituel est symbolisée par l'interdiction faite aux marabouts locaux d'assister à la tajmaat (sauf dans les villages exclusivement ou majoritairement composés de familles maraboutiques). La tajmaat, institution kabyle au sens large qui se trouve aussi dans certaines zones arabisées anciennement kabyles du Nord constantinois, n'hésite pas à ériger des lois (qanun) parfois même en contradiction avec le droit musulman. Par exemple, le règlement des cas de vol ou de meurtre ainsi que le droit relatif aux successions obéissent en Kabylie à des logiques différentes de celles du droit coranique. Ce droit coutumier kabyle autonome fit grande impression sur les auteurs coloniaux, au premier rang desquels les généraux Hanoteau et Letourneux qui en firent même un recueil. (PLANTADE, 2007, p. 86)

Essa "laicidade", ao mesmo tempo em que impressionou a Administração Colonial Francesa, sendo por ela utilizada para disseminar uma rivalidade entre cabilas e árabes, foi reivindicada pelos próprios cabilas emigrados, inseridos nos movimentos políticos sindicais europeus do início do século $X X$, e por esses movimentos influenciados pelo seu forte viés anticlerical. Singularmente, o comunitarismo "arcaico"224 cabila tornou-se uma referência concreta dentro dos movimentos operários europeus socialistas e anarquistas. Essa consideração foi amplamente divulgada e reforçada por Mohamed Saïl (1894-1953), anarquista argelino de origem cabila, pioneiro na luta anticolonial argelina e provavelmente o primeiro a declarar publicamente seu ateísmo:

Cette revendication égalitaire poussa également les Kabyles émigrés depuis la Première guerre mondiale en France métropolitaine--où ils constituaient, de très loin, la communauté immigrée extraeuropéenne la plus large--à intégrer les mouvements sociaux structurant le monde ouvrier. Pour la plupart, peu éduqués et donc guère sensibilisés à la laïcité scolaire, ces émigrés étaient exposés aux idées sécularistes pour la première fois au sein des syndicats et partis ouvriers anarchistes, communistes et socialistes, tous porteurs d'un anticléricalisme radical. Marx lui-même, suite à son voyage en Algérie en 1882, avait décrit l'organisation villageoise kabyle comme un exemple concret du socialisme de ses rêves. Ce militantisme kabyle en métropole aboutit à la politisation et à la laïcisation de plusieurs milliers d'individus, lesquels transmirent leurs idées révolutionnaires nouvellement acquises lors de leurs retours ponctuels ou définitifs en Kabylie. Le cas de Mohamed Saïl, aussi exceptionnel qu'il soit, n'en est pas moins éclairant. Dans les années 1920, ce Kabyle rejoignit définitivement la mouvance anarchiste, qu'il fréquenta tant en Algérie qu'en Europe. Saïl fut probablement le premier Kabyle à affirmer publiquement son athéisme : "Allah est en

\footnotetext{
${ }^{224}$ A etimologia da palavra "arcaico" tem origem no grego archaïkós, significando antigo, primitivo. Associado à raiz "arché", seu significado remonta ao "princípio", "original", "começo". Nesse sentido, a palavra é aqui empregada para designar essa organização "original", contrariando qualquer acepção etnocêntrica difundida pela leitura europeia e moderna sobre essas instituições.
} 
déroute " écrivait-il en 1951 dans Le Libertaire. II en vint même à proposer à ses camarades anarchistes européens le concept de village kabyle comme modèle de commune autogérée. (PLANTADE, 2007, p. 90)

Inspirada pela singularidade da separação religiosa da política local e, portanto, à luz da reelaboração dessas antigas instituições políticas ${ }^{225}$, com suas adaptações e transformações ao longo da história desses povos, essa "laicidade" e esse "ateísmo" tornaram-se emblemas recorrentes associados aos povos cabilas, reivindicados principalmente por uma parte de sua juventude na década de 1980.

5.1.2 Sincretimos: o islã cabila, rituais e festas

Para Lacoste-Dujardin (2005), as antigas mitologias subsistem ainda nas crenças e nos ditados populares, dando ao islã cabila matizes bastante sincréticas $^{226}$. O islã cabila conhece formas de culto de lugares sagrados (grutas, rochas, árvores, fontes, etc.), que existem desde a pré-história, nos quais reverbera o culto aos 'guardiões' (aâssas), tipo de entidades mágicas habitantes desses lugares. Nas vilas ${ }^{227}$, cada construção, cada casa tem um aâssas, como em cada sala de reunião dos homens da vila (tajmaât), cada bairro (adrum) e cidade têm o seu guardião. Na natureza, esses guardiões habitam as velhas e grandes árvores, fontes, rochas, grutas e, às vezes, habitam também as tumbas dos santos locais (LACOSTE-DUJARDIN, 2005). Não importa onde se esteja, não se pode deixar de cumprimentá-los ou dar-lhes oferendas.

${ }^{225}$ Essa rejeição da religião também se expressa na poesia cantada por artistas populares da Cabília, Menguellet Lounis Aït tal, ou Lounes Ferhat Matoub Mehenni. Matoub, em sua canção «Allahu Akbar», faz um ataque frontal ao Islã, criticando seus valores. Allahu Akbar é uma expressão em árabe que significa "Deus é amor", "Deus é bom".

${ }^{226}$ Compreende-se 'sincretismo' como uma mistura de elementos míticos e ritualísticos oriundos da influência islâmica e da cultura amazigh (berbere). Tais elementos, amalgados e reinventados durante o processo histórico de formação da cultura cabila, geraram aquilo que se chama de 'islã cabila', sendo a expressão máxima desse hibridismo, pelo qual o islã professado pelos marabutos, reincorporado na cultura berbere dos mitos e rituais desses povos, somada à influência mediterrânea, fomentaram as especificidades culturais e religiosas desses povos.

227 Tomamos a acepção de vila como uma povoação de categoria inferior à cidade e superior a uma aldeia (DICIONÁRIO AURÉLIO, 2010). Algumas vilas cabilas eram densamente povoadas e chegaram a possuir cerca de quinze mil habitantes em 1857. 
Nos vários santuários, as mulheres realizam diferentes ritos para solicitar-lhes favores: acendem velas, fazem promessas, ofertam biscoitos e figos, se banham em suas fontes, amarram fitas nas árvores, depositam miniaturas de cerâmicas, cantam e dançam em reverência a esses guardiões. Às vezes, esses santuários recebem encontros festivos com seksou (cuscuz) de carne, na ocasião de festas muçulmanas como a Achoura ${ }^{228}$ ou a Mouloud ${ }^{229}$. Atualmente, os cultos aos guadiões, como os cultos aos santos, não são praticados com a mesma frequência de antigamente.

O islã é também muito presente na vida cotidiana, encontrando-se impregnado nas promessas proferidas, nas invocações repetidas e nas práticas religiosas. $\mathrm{O}$ jejum do ramadã ${ }^{230}$, as orações e a caridade são hábitos incorporados entre os cabilas. Outro aspecto relevante são as peregrinações, sendo as peregrinações à Meca feitas pelos membros da família vistas como um ato piedoso realizado principalmente por homens. Os que as realizam são vistos com grande admiração, mas tal ato é visto com ambiguidade na cultura cabila. Se a ida à Meca consiste em uma forma de respeitabilidade e distinção, ao mesmo tempo, em vários contos tradicionais, a ausência do pai privava a família da defesa masculina, considerando-se, então, um ato de abandono. Assim, na sabedoria cabila a ida à Meca não é uma obrigação, pois, em certo sentido, poderia representar um ato desnecessário, vide o ditado cabila que considera a caridade uma ação compensatória a ela: "Mieux vaut un galette chaude [fazer caridade] que la Kaâba [que o santuário em Meca] das ses murailles" (LACOSTE-DUJARDIN, 2005, p. 281). Entretanto, as peregrinações locais aos numerosos santos ${ }^{231}$ da Cabília são mais

${ }^{228}$ Grande festa muçulmana celebrada no $10^{\circ}$ dia do mês do ano lunar após a "grande festa" de sacrifício abraâmico, em alguns países islâmicos é a ocasião para a realização de atos públicos de flagelação. Na Cabília, é o momento das mulheres visitarem os santos locais e reverenciarem os guardiões. Também na Cabília é realizado um carnaval onde o cortejo é conduzido por pessoas mascaradas ou por uma pessoa sentada num asno. Segundo Lacoste-Dujardin (2005), este carnaval é uma herança de uma forte tradição berbere de ritual de fecundação. Muitas vezes essas festas duram sete dias, nos quais as pessoas trabalham pouco e oferecem esmolas àqueles que precisam.

${ }^{229}$ Festa de nascimento do profeta Mahomé, celebrada no terceiro mês do ano lunar. É comemorado com luzes em casa e com elementos importantes na casa: jarras de azeite, água, etc. Consomese carne, bouillie (uma espécie de patê de semolina, cozido e com manteiga), crepes.

${ }^{230}$ No nono mês de 30 dias do calendário islâmico é realizado o jejum entre os mulçumanos, do levantar ao pôr do sol. O jejum, o ramadã, entre os mulçumanos é também acompanhado da abstenção sexual, conferindo a esse período um momento de meditação e autocontrole entre os seus devotos.

${ }^{231}$ Os santos mais populares da Cabília são os quatro fundadores dos principais centros religiosos da região, que habitavam o alto de Djurdjura: a colina de Tizi Berth, a leste de Tirourda. Esses santos foram: Sidi Mansour, Sidi Ahmad u Dris, Sidi Ahmad u Malek e Sidi Abd El Rahman AL Yalouli. Outros santos, também chamados de marabutos, com reputação local, possuem tumbas ou lugares sagrados por onde eles passaram. Nesses espaços, principalmente de rochas, grutas e 
frequentente e realizadas, sobretudo por mulheres. É certo que nos últimos tempos houve uma diminuição na frequência, mas ainda persiste como uma ocasião para se festejar e para se fazer pedidos aos santos, como solicitar o retorno dos emigrados, etc.

Também entre os cabilas os sacrifícios rituais são bastante praticados. A oferenda ritual se caracteriza pela imolação de animais como forma de benção. Eles podem ser públicos ou privados. Os sacrifícios públicos são executados em diferentes ocasiões: um mês depois do fim do ramadã, à lâid tamoqrant (sacrifício abraâmico, "a grande festa", com o degolamento de carneiros), ou no primeiro dia do ano, ou em ocasiões decididas pela assembleia da vila (jemâa), como os "sacrifícios compartilhados" (na língua berbere, timecrett ou ouziâ, em francês sacrificiespartages) (LACOSTE-DUJARDIN, 2005).

Vale à pena detalhar o "sacrifício compartilhado" porque este se tornou, ao longo dos tempos, um indicador valorizado pela identidade cabila ao associar esse costume a sua raiz igualitarista de participação coletiva. Ao contrário da lâĩd tamoqrant (da "grande festa"), uma comemoração muçulmana anual, familiar e única, o timecrett ou ouziâ pode ser realizado várias vezes ao ano e envolve toda a comunidade da vila. As ocasiões para sua realização vão desde a inauguração do ano agrícola (em outono) à celebração do retorno de um emigrado; ou para afastar uma ameaça à comunidade (doenças, epidemias, etc.). Esses sacrifícios podem ser realizados por iniciativa privada ou comunitária (jemâa), com a participação de toda a comunidade masculina na sua organização, preparação e realização. Isto é, é uma obrigação exclusivamente masculina (as mulheres não participam em nenhum momento do sacrifício), que abrange a contribuição financeira coletiva para a compra dos animais (gado) e sua participação durante o ritual:

Ce sacrifice collectif réunit tous les hommes em um lieu proche de la tajmaât (maison des hommes) ou d'un point d'eau. Les bêtes sont souvent des bovins. Les chefs des lignages, les imgharen (grands) $d u$ village, assistent et surveillent le déroulement très codifié de la cérémonie. Les prières préables, celles de l'immolation comme de remerciement aux donateurs, sont dites en kabyle. (LACOSTEDUJARDIN, 2005, p. 311)

fontes, costuma-se realizar rituais tradicionais anteriores à islamização. Cada tribo (clã) também possui seus santos. No caminho desses lugares dos santos objetos de peregrinação localizam-se também os "guardiões" (aâssas). Ao contrário dos santos, que tiveram uma história, uma "vida", os guardiões sempre foram entidades espitiruais localizadas e que continuam a habitar esses espaços. 
Assim, a compra, a preparação e a divisão da carne dos animais sacrificados é um ato coletivo que reúne todos os homens da vila (ricos e pobres). O consumo da carne é feito pelas famílias, uma ocasião de união em que as mulheres podem participar na preparação dos pratos com a carne sacrificada, uma vez que elas também as salgam e as secam para a conservação. Inscrito em novas estruturas, esse sacrifício ritual masculino, atualmente menos frequente, sofreu uma verdadeira mudança funcional, sendo valorizado como uma referência identitária cabila mais pelo reconhecimento de sua diferença do que pela realização do ritual em si.

Existem outros momentos para se fazer sacrifícios: nas fundações da casa em construção (mata-se carneiro e bode), nos casamentos, no ritual da henna ${ }^{232}$, bem como nos ritos de passagens (nascimento, circuncisão e morte).

\subsubsection{Tradição oral: mitos e contos}

Se a religiosidade cabila se expressa pela mistura dos rituais islâmicos com as antigas mitologias berberes, como os aâssas, os "guardiões", a cultura mediterrânea é outro elemento presente nesse cadinho cultural. Com o mundo mediterrâneo, a cultura cabila tem em comum valores e representações, sendo um deles o patriarcado, alinhado ao valor essencial da fecundidade das mulheres e dos homens. Segundo Lacoste-Dujardin (2005), essa representação é compartilhada de Homero e Santo Agostinho ao Alcorão: grãos plenos e ventres plenos como uma garantia de vida em torno de uma mesma metáfora do homem que trabalha a terra, obtém também sua fertilidade, como a fecundidade de sua mulher. Essa representação justificaria a dominação masculina e o papel das mulheres ligado à vocação da fecundidade, seu confinamento no universo doméstico e a segregação entre os sexos, elementos constitutivos do patriarcado.

Ao lado dessa estrutura patriarcal comum, algumas narrativas, como os contos "Mqidech" 233 , "Ali e sua mãe"234 e "Aladin" guardam estruturas muito símiles e

\footnotetext{
${ }^{232}$ A tintura da henna utilizada entre as mulheres nos cabelos possui propriedades profiláticas, poder de proteção, mágica e medicinal, garantindo fecundidade e baraka (graça divina). São aplicadas principalmente em cerimônias e festas: circuncisão, festa do sacrifício abrâamico e, sobretudo, em casamentos (onde a henna dá nome ao ritual que antecede o casamento).
} 
vívidas nas culturas mediterrâneas, nas quais a memória oral desse povo é a grande depositária de seus contos e mitos.

Dessa tradição oral sincrética, inúmeros mitos circundam o imaginário cabila. Lacoste Dujardin (2005, p. 255) sublinha que «Certains kabyles se souviennent toujours de ces mythes que imprègnant la tradition orale et qui ont pu être collectés avant d'être oubliés». A qualidade dos contos cabilas de tradição oral é, segundo Lacoste-Dujardin (2005), um verdadeiro tesouro, digna de figurar no primeiro ranking do patrimônio internacional. Para a etnóloga, essa qualidade advém da consubstanciação de uma antiga tradição oral de mitos presente no mundo mediterrâneo, com o aporte pertencente ao fundo universal dos temas, mas somente retransmitido pela escrita, como é o caso dos contos de "Mil e uma noites", difundido em língua árabe, frequentemente retomada pela transmissão oral.

Os contos mediterrâneos são obras locais, rurais, pertencentes ao repertório feminino, como no conto Mil e uma Noites, trazidos por homens que frequentavam à Cabília. Os primeiros contos narrados pelas mulheres são mais antigos e estão presentes na memória dos camponeses, retratam seus heróis defensores da comunidade contra as forças maléficas da natureza: ogressas, hidras de sete cabeças, dragões e outras forças sobrenaturais do mundo selvagem. Ao contrário, os contos narrados pelos homens são sobre os cidadãos do mundo maravilhoso dos reis e sultões com seus palácios urbanos, seus heróis são dotados de um poder pessoal e frequentemente casam com a filha do rei ("Aladin" e outros).

Ainda na tradição oral cabila prefigura uma rica cosmologia formada por um mundo subterrâneo, invisível, mas, no entanto, povoado de seres. É o mundo das trevas, estéril, sendo todo o contrário de um mundo humano na terra, fértil e organizado. Esse mundo orgânico inverso à terra prefigura entidades fantásticas,

${ }^{233}$ Mqidech é um heróis mais conhecidos e populares da literatura oral cabila. A origem do seu nome vem da raiz "servir, ajudar em casa", sublinha sua vocação doméstica que o predispõe ao papel mediador entre o mundo feminino e masculino. Ele é um jovem garoto de uma família de sete irmãos. Após comer a metade de uma maçã, sua mãe o concebe. Por isso, ele nasce ambivalente, metade homem, incompleto, entre o normal e o sobrenatural. Metade homem, às vezes caseiro e caçador, Mqidech pode agir às vezes em casa e no exterior. Sua clarividência e malícia lhe permitiram escapar da 'ogressa', mulher destrutiva e devoradora que queria devorar a ele e aos seus irmãos. Após escapar, Mqidech evitou os ciúmes dos irmãos que não acreditavam em seu feito, matando a ogressa. Conseguiu, assim, restabelecer o equilíbrio interno de sua família.

234 "Ali e sua mãe" é um dos muitos contos cabilas. É uma tragédia que envolve uma mãe terrível e seu filho, Ali. Ao poupar a mãe de matá-la sob as ordens do pai, a mãe, ao contrário, junta-se a um ogro e tenta matar Ali, porque não queria viver isolada. Ao escapar várias vezes de ser assassinado pela própria mãe, ele a mata, casando-se em seguida. 
gigantes, anões, gênios, ogros e ogressas. Só os mediadores ${ }^{235}$ podem se comunicar e atravessar esse universo através dos poços, das grutas, de portas de ferro. Lá estão os gênios, as serpentes, os mortos que à noite podem ir à terra, cabendo aos homens mais valorosos e piedosos enfrentarem essas forças.

Nos tempos míticos da origem, segundos os cabilas mais velhos, apareceram sobre a terra os primeiros quarenta jovens e as primeiras quarenta jovens mulheres provenientes do mundo subterrâneo. Como vieram separados, se desconheciam. Até que as jovens mulheres, curiosas, se aproximam dos homens e nasce dali uma forte atração entre eles, marcada principalmente por suas diferenças. As mulheres (como sempre...) seduzem os homens, tendo as primeiras relações sexuais do mundo, e gerando, por sua vez, os primeiros ascendentes humanos na terra. A civilização se constitui quando os homens começam a construir suas casas, reunindo nelas as mulheres e seus filhos.

Existiria ainda, anterior à chegada dos jovens à terra, a "primeira mãe do mundo" (yemma $n$ dunnit). Mulher benevolente quando jovem, desenvolveu, na maturidade, uma maldade que a fez tornar-se uma bruxa. Criadora das nuvens, das estrelas, das ovelhas, semeou a discórdia ao lançar a incompreensão entre os homens, sendo a responsável pela variedade de línguas no mundo. Ela teria criado os macacos, que seriam os homens que caíram em seus maus conselhos; por isso, ela instituiu a morte entre eles.

Os ditos e provérbios contados pelas mulheres nas peregrinações aos locais santos, os poemas das músicas de festas e do ritual da henna compõem esse rico universo oral a ser ainda difundido (LACOSTE-DUJARDIN, 2005).

\footnotetext{
${ }^{235}$ Nos contos cabilas, os mediadores são os heróis que exercem esse papel mediador entre a terra e a natureza selvagem. Eles são experts em atravessar as dicotomias: dia-noite, interior-exterior, como eles mesmos estão nos limites do natural e sobrenatural. Alguns objetos possuem esse status mediador entre natureza e cultura, como o ferro do arado que fecunda a terra.
} 
5.1.4 Literatura oral ${ }^{236}$ e produção audiovisual

A entrada da língua oral para a escrita ocorrerá a partir de 1970, com a tradução do seu rico patrimônio cultural por parte de intelectuais cabilas que estudaram em escolas francesas. A língua berbere, transcrita com base no alfabeto latino, também serviu para a tradução e adaptação de obras literárias universais (Molière, Brecht, etc.) e magrebinas (Kateb, Feraoun, etc.).

Contudo, a referência sobre essa tradição oral cabila será reportada àquilo que a etnóloga Camille Lacoste-Dujardin designou como "literatura escrita de expressão francesa", os primeiros romances escritos por alguns militares franceses que descrevem a natureza fantástica do universo mítico cabila. Em seguida, esse universo se reporta aos escritos dos próprios cabilas, por meio das obras de Mouloud Feraoun, Mouloud Mammeri ${ }^{237}$ e os membros da família Amrouchem ${ }^{238}$, além de autores como Tahar Djaout e Malek Ouary, para citar alguns.

Essa "literatura escrita de expressão francesa" deu origem à literatura escrita cabila, em parte prosa (romances) e em parte poesia, originada da tradição popular da poesia e da música cabila. Entretanto, essa literatura cabila, segundo LacosteDujardin, é bem mais antiga e remonta aos séculos anteriores à islamização, no qual a tradição oral dos contos e das aventuras dos personagens era transmitida de geração em geração, marcada pela interação entre o narrador e os ouvintes:

Aussi peut-on dire de la littérature orale kabyle qu'elle peut être définie comme un "ensemble d'expressions no écrites, produites par un individu (c'est le cas des poésies), mais plus souvent par le groupe social (c'est le cas des contes et des mythes), et que toutes

${ }^{236}$ A literatura oral designa a antiga arte de exprimir eventos reais ou fictícios. Resulta do trabalho de recriação oral de um patrimônio cultural comum, de uma memória coletiva, transmitida entre gerações em forma de contos, lendas, mitos, parábolas, poemas (SCHOLES e KELLOG, 1987).

${ }^{237}$ Mouloud Mammeri (1917-1989) foi escritor, antropólogo e especialista da cultura cabila. Nasceu em Taourit Mimoun, pertencente a uma tradicional família de intelectuais cabila. Seu primeiro romance publicado em francês La colline oubliée (1952), transformou-se em filme e em grande referência para a comunidade cabila. Publicou diversas obras e artigos. Foi professor de berbere na Universidade de Argel, onde impulsinou a pesquisa em pré-história e em antropologia. Foi diretor do CRAPE (Centre de Recherches en Anthropologie, Préhistoire et Ethnologies) de Argel, além de outros cargos notáveis. Em 1980, após uma conferência sua sobre a poesia antiga cabila ter sido impedida pelo governo argelino, é o desencadeador da chamada Primavera Berbere, uma série manifestações e enfrentamentos da população cabila contra as forças do governo argelino.

${ }^{238}$ Família de escritos cabilas de língua francesa que produziu inúmeras obras com referências à cultura tradicional cabila. Eles eram uma elite cabila de formação cristã (convertida no final do século XIX), educada pelos jesuítas dos Souers Blanches e Pères Blancs na Cabília. 
ces productions, très élaborées dans leur forme et leur contenu, sont faites pour être répétées et transmises au sein de la société kabyle». Ainsi, en tant que "discours que la société se tient à elle-même», la littérature orale kabyle est une partie très important de la culture kabyle proprement dite. (LACOSTE-DUJARDIN, 2005, p. 216-217)

Muitas produções audiovisuais registram essa tradição oral, baseada nos contos e mitos cabilas. Alguns se destacam, como os filmes baseados nos contos mais tradicionais cabila, "La legende de Vava Inouva" e de "Dans la nuit", adaptação das aventuras de Mqidèch, do diretor Rabie Benmokhtar, ambos lançados em 2007, e em tamazight (língua berbere). O primeiro filme em tamazight, baseado no romance de estreia de Mouloud Mammeri, "La colline oubliée" (1997), dirigido por Abderrahmane Bouguermouh, foi um marco no gênero. A história se passa durante a Segunda Guerra Mundial, onde um pequeno povoado cabila, cravado nas colinas do Djurdjura, tem seu cotidiano modificado com a guerra e com o domínio colonial francês. Para o diretor, esse filme comprometeu-se com uma memória ainda presente no imaginário dos cabilas, da sua geografia ao seu passado colonial, são marcas para toda a vida:

Il y a aussi ce contrat passé avec la Kabylie: œuvrer pour la renaissance de sa culture. La Colline oubliée est aussi un beau roman qui décrit les années terribles de la deuxième guerre mondiale. Le malheur était partout et quelques éclats ont brûlé ma toute jeune mémoire. Il est tout à fait normal qu'un premier film remonte à ces premiers souvenirs, ceux qui vous laissent des stigmates pour la vie. (BOUGUERMOUH, 1997) $)^{239}$

Apesar do enfraquecimento de estruturas tradicionais como as encarnadas pelo tamusni, a filosofia "prática" de excelência berbere, qualidade dos amusnaw (sábios formados por esse conhecimento prático, mas altamento erudito, aprendido com o requinte da observação, da sensibilidade e da aquisição de técnicas da oratória), a passagem escrita desse conhecimento, sua inscrição midiática pôde lançar-Ihes novas possibilidades de reelaboração. O antropólogo e escritor cabila Mouloud Mammeri, autor da obra La Colline oubliée, filho do último amusnaw de seu clã (Aït Yenni), conseguiu transcrever uma parte desse conhecimento, em sua

\footnotetext{
${ }^{239}$ Artigo escrito por Abderrahmane Bouguermouh no site: Algérie Littérature Action, n. 7-8, disponível em: http://marsa-algerielitterature.info/cinema/63-la-colline-oubliee-un-film-de-abderrahmane-bou guermouh-dapres-le-roman-de-mouloud-mammeri-sortie-en-salle-mars-97.html. Acesso em: 11 jul. 2012.
} 
pesquisa sobre a poesia antiga cabila ${ }^{240}$. Em conversa com o Pierre Bourdieu, ele explica essa filosofia oriunda de um saber prático encarnado na sabedoria:

O aprendizado era pela prática. Não era um aprendizado abstrato. Era preciso agir também segundo certo número de preceitos, de valores, sem os quais a tamusni não é nada. Uma tamusni que não se adota, que não se vive, não passa de um código. A tamusni é uma arte, é uma arte de viver, ou seja, é uma prática que se aprende pela prática e que tem funções práticas. As criações que ela propicia - poemas, máximas - não são arte pela arte, mesmo que sua forma, eventualmente muito rebuscada, muito refinada, possa sugeri-lo... (Entrevista de Bourdieu à Mouloud Mammeri, publicada no Brasil em 2006)

Essa passagem dessa tradição da oralidade para a escritura e para o audiovisual mostra uma rica passagem mediológica ${ }^{241}$ de um patrimônio cultural, referência base da reivindicação da especificidade da identidade cabila. Mais uma vez, a técnica ultrapassa o significado instrumental e passa a agir no modo de ser do grupo. Sem a vinculação e a capacidade de transmissão oferecida pelas relações com os objetos técnicos (sejam eles livros, vídeos ou qualquer suporte para a informação desse patrimônio cultural), esgotam-se as possibilidades de perpetuação de uma memória. Obviamente não é apenas o registro que se basta para a existência dessa memória coletiva, mas certamente o registro e o tipo de linguagem associados a ele (escrita, audiovisual, sonora) possibilitam que se torne uma "perpetuação" e que "vença" o esquecimento. Tal processo está intrinsecamente ligado à plena dinâmica das culturas, de suas transformações, reelaborações e circunstâncias. Desse processo, os objetos técnicos tanto quantos as relações entre os membros de seus grupos são os agentes dessa jornada, da memória e da autopercepção do grupo.

A importância das mídias, sobretudo das digitais, pelas particularidades já citadas no primeiro capítulo da tese, será de tal amplitude para os que já não estão na Cabília, pois suas relações com as tecnologias de informação e comunicação

${ }^{240}$ Além do amusnaw havia os ameddah, os poetas ambulantes com seus temas recorrentes ao Alcorão. Ambos tinham nos deslocamentos, fosse por outros clãs, vilas e feiras, suas bases para observar, aprender e criar. Mouloud Mammeri foi um amusnaw por excelência, mediador e tradutor da rica tradição oral de seu clã para a forma escrita.

241 Os estudos mediológicos foram inaugurados por Regis Debray, que analisou o signo como meio de transmissão cultural. O sociólogo italiano Alberto Abruzzese entende a mediologia como um novo campo transdisciplinar, direcionado ao estudo sociológico, comunicativo e histórico (genealógico) dos processos socioculturais e midiáticos. 
selam, de fato, seu vínculo com essa "comunidade imaginada" cabila. Mais uma vez, só é possível imaginar-se em comunidade pelos aparatos técnicos comunicativos (APPADURAI, 2001). Tal argumento nos conduz diretamente aos processos diaspóricos dos cabilas, como expressão de um local digital das culturas no contexto atual dos processos globais. Veremos, no próximo subitem, a relevância das mídias digitais para essa comunidade cabila na França.

\subsubsection{Tradição musical}

Se os contos e mitos formam esse quadro vasto e rico do patrimônio cultural cabila, instituindo-lhes uma singular identidade cultural, a música é um dos elementos mais significativos desse patrimônio, presente no cotidiano e nas festas. Todas as comemorações cabilas são acompanhadas de muita música. Os cantos são entoados por mulheres ${ }^{242}$, acompanhadas pelo som dos tambores. Também algumas reuniões religiosas são acompanhadas de cantos místicos religiosos, sendo cada atividade no campo associada a determinadas canções tradicionais.

Os grupos profissionais geralmente eram formados por um cantor, acompanhado de músicos que tocavam tambores e oboés. Nos anos 1940 a 1960, período de intensa migração de cabilas para a França, o tema das canções sofreu a influência da luta anticolonial e, ao mesmo tempo, da música magrebina, graças aos músicos de origem árabe, judia e das músicas do Oriente Médio. Após a independência, a música cabila se desenvolverá consideravelmente, incorporando o violão, o banjo e o mandolim e o acordeón (influência francesa). Cantores como Idir, Slimane Azem e Lounés Matoub vão difundir as canções cabilas para além das fronteiras argelinas e francesas.

Atualmente, a música é um dos mais fortes elementos da cultura cabila difundida em suas comunidades diaspóricas. Os shows, os concertos e as festas são eventos fundamentais para a performatização da identidade cabila por meio das canções em amazight. A circulação e a difusão dessa tradição musical adquirem

${ }^{242}$ Além dos cantos, as mulheres cabilas, como as árabes, costumam emitir, nas festas, um grito estridente e repetitivo, chamado de Youyous (ou tighratin ou aslilew, dependendo da região). Esses gritos eram reverberados, nos tempos de guerra, para encorajar os homens. 
grande reverberação nos circuitos digitais da rede (CD's, Youtube, entre outros). Os vínculos com a territorialidade e com a cultura cabila são restabelecidos nesses circuitos e são fortalecidos nos momentos de reterritorialização. Muitas das associações berberes-cabilas na França são de cunho cultural, promovem festas, encontros, debates literários, tudo acompanhado de muita música amazigh.

\subsection{COLONIZAÇÃO FRANCESA, INDEPENDÊNCIA E PÓS-INDEPENDÊNCIA ARGELINA}

A história contemporânea da Cabília durante o período da colonização francesa (1830-1962) é marcada por dois grandes eventos: a conquista e a colonização francesa propriamente dita (1830-1954) e a Guerra da Independência (1954-1962).

A conquista pelo exército francês começa em 1830, impondo seu domínio nas regiões da costa argelina. A pesada artilharia, a difusão de doenças, a devastação da agricultura e a imposição de tributos aos territórios conquistados delinearam a condução da estratégia colonial. Entretanto, as resistências foram inúmeras, entre elas a mais conhecida, a insurreição de 1871, uma revolta de aproximadamente 120.000 combatentes cabilas contra as forças francesas, que levou a Administração Francesa a restabelecer instrumentos de assimilação, adotando a escolarização na região como método de manutenção da conquista.

Dentro dessa estratégia, a conquista e a colonização francesa realizarão aquilo que Lacoste-Dujardin (2005) chamou de "etnopolítica de divisão", operada pela administração colonial francesa com base na alimentação de uma rivalidade, "aversão recíproca" Árabe e Cabila com bases raciais. Essa tese será fortemente difundida e disseminada pelo general francês Daumas (1839-1856) por meio de seus livros e textos sobre a Cabília:

S'est développée ainsi une dichotomie manichéenne arabe-kabyle, dans tout les domaines: aspect physique, activités, morale, tradicions, religion, situation des femmes, etc., créant ainsi une imagerie qui opposait, sans nuances, au mauvais Arabe un Kabyle vertueux. La Kabylie a, certes, bénéficié de cette considérations particulière, mais elle lui a aussi fai grand tort, en donnant de la 
culture kabyle une fausse représentation, archaïsant, figée, conservatrice, monolithique, sans nuances ni mouvement. (LACOSTE-DUJARDIN, 2005, p. 67).

De fato, essa estratégia colonial obteve um êxito parcial impresso nas relações entre esses povos (cabilas e árabes do restante da Argélia), já marcados por suas diferenças culturais e religiosas. Os franceses identificarão essa característica como um 'islã laico'. A laicidade cabila (ou berbere) foi um aspecto contrastivo amplamente explorado pela administração colonial francesa e largamente sublinhado pelo movimento berberista (berberisme), nascido entre esses grupos cabilas durante a Segunda Guerra Mundial. Tal movimento proporcionou à língua e a seu aspecto religioso "laico" o contorno cada vez mais forte e inspirador de uma autonomia política local.

O islamismo argelino é, sobretudo, de origem sunita e salafita ${ }^{243}$, o que determinará a presença desses grupos religiosos na política local após a independência, tensionado com os grupos cabilas. Ao explorar essas diferenças, a etnopolítica colonial investiu em escolas laicas na região da Cabília, produzindo, ao mesmo tempo, os paradoxos da política colonial. Tal processo de escolarização e de formação de uma elite intelectual cabila fortificará a ligação cabila com a França, com os valores laicos e se tensionará pela valorização de uma identidade berbere, em contraste à árabe e francesa. No entanto, é entre a comunidade cabila "esclarecida" que nasce a consciência de uma política nacionalista argelina.

Ainda durante o período da colonização francesa, os jovens cabilas incitaram um movimento chamado de berberismo (berbérisme) durante a Segunda Guerra Mundial (1941-1945), ampliado no período da independência argelina e ainda forte na região e nas comunidades diaspóricas cabilas. Não se tem precisão da origem desse movimento ideológico, político e cultural associado à identidade berbere. Lacoste-Dujardin indica alguns nomes, como de Mohamed Saïl, cabila militante pela independência da Argélia pertencente a um grupo anarquista. A etnóloga comenta sobre o grupo do liceu Ben-Aknoun (Argel) e outros militantes, entre eles os cabilas Hocine Aït-Ahmed, Ouali Bennaï, Said Chabane, Ali Laïmèche, Amar Ould Hamouda, Amar Oussedik (esse grupo constituiria as bases do Partido do Povo Argelino (Parti Du Peuple Algérien), além da participação dos escritores Kateb

${ }^{243} \mathrm{O}$ salafismo é originário de uma corrente do movimento sunista que reivindica o retorno às origens do Islã. Corrente fundamentalista e tradicionalista, contrária a qualquer tipo de modernização ou ocidentalização dos costumes socioculturais islâmicos. 
Yacine e Mouloud Mammeri. Deve-se a esse grupo o que se tornaria o hino de reivindicação berbere: Ekker emmis-s amazigh (De pé, filhos berberes), criado por Mohand u Idir Aït-Amrane, em janeiro de 1945 (LACOSTE-DUJARDIN, 2005). Muitos desses intelectuais, escritores, poetas e músicos reinscreveram a tradição oral popular cabila para os gêneros da literatura e da música. Essa passagem midiática dessa identidade é uma das suas características mais marcantes, por onde a língua cabila, a musicalidade e a poesia desses povos serão disseminadas no mundo, principalmente na França. Na ocorrência da diáspora cabila/berbere, essa terá forte vínculo artístico como fonte e base da identificação desses povos para além da Cabília.

Com a crescente discussão pela independência argelina e em direção de uma aliança entre os diversos grupos políticos existentes, o Partido do Povo Argelino é dissolvido e torna-se um movimento mais amplo, denominado Mouvement pour le triomphe des libertés démocratiques (MTLD). Contudo, em 1949, tem-se o primeiro embate público entre as forças nela existentes, conhecido como a "crise berberista" (crise berbériste). O grupo berbere, liderado por Rachid Ali Yahia, reinvindicava uma "Argélia argelina" em contraposição a uma "Argélia muçulmana e árabe". Em 1948, o MTLD envia um documento à ONU, que começava da seguinte forma: "A nação argelina, árabe e muçulmana, existe desde o século VII século". Tal texto causa efeitos imediatos e Rachid Ali Yahia organiza uma votação dentro do MTLD, em março de 1949, a favor de uma moção defendendo a 'Argélia argelina', contestando não só a colonização francesa, mas a tese da nação árabe-muçulmana. A direção do MTLD toma a frente dessa controvérsia interna, evitando a divisão do grupo, mas isso expôs a fragilidade de um discurso nacionalista frente às identidades existentes, fortemente marcadas pelo aspecto religioso árabe e mulçumano. Naquele momento, os grupos berberes propunham um projeto de nação laica destituído de uma marca étnica religiosa, primando pela unidade argelina, baseado na sua antiguidade cultural anterior à dominação árabe.

Durante a Guerra da Independência (1954-1962), a administração colonial francesa rearticulou os chamados "reassentamentos" e as famílias camponesas foram forçadas à migrarem para uma região pré-estipulada pelo governo. Pierre Bourdieu e Abdelmalek Sayad, no ensaio intitulado "A dominação colonial e o saber cultural" (publicado no Brasil em 2006), analisam as consequências dessa estratégia colonial para a sociedade argelina: 
De todas as transformações que a sociedade rural argelina sofreu entre 1955 e 1962, aquelas que foram provocadas pelos reassentamentos de populações são, sem dúvida, as mais profundas e as que tiveram maiores conseqüências a longo prazo. [...] De acordo com uma diretriz oficial, o principal objetivo das zonas proibidas era o de "esvaziar uma região não controlada e afastar a população da influência rebelde". O reassentamento em massa das populações em centros situados próximos de instalações militares tinha como objetivo permitir ao Exército um controle direto sobre elas, de maneira a impedir que transmitissem informações, fornecessem orientações, mantimentos ou alojamento aos soldados do Exército de Libertação Nacional (ALN); era também uma forma de facilitar a repressão, ao autorizar que fossem considerados "rebeldes" todos aqueles que permanecessem nas zonas proibidas. $\mathrm{Na}$ quase totalidade dos casos, a exclusão foi feita à força. No início, o Exército parece ter aplicado sistematicamente, pelo menos na região de Collo, uma tática de terra arrasada: incêndio das florestas, destruição de reservas e de gado - todos os meios foram utilizados para obrigar os camponeses a abandonar sua terra e suas casas. (BOURDIEU e SAYAD, 2006, p. 41-42)

A expulsão dos camponeses provocou um grande êxodo para as cidades e os duros combates travados na região da Cabília eliminariam parte da militância berbere que acreditava numa 'Argélia dos argelinos'. Liderados pelo Front de libération nationale - a Frente de Liberação Nacional (FLN) -, os opositores à administração colonial francesa deflagrariam uma luta sagrenta, na qual a França utilizaria de todos os meios, a tortura, a censura, a contraespionagem. Em uma operação intitulada "Oiseau Bleu" (1956), a França apostaria em uma contraespionagem cabila, fornecendo-lhes armas e dinheiro para que desmantelassem as forças FLN, ao acreditarem no apoio cabila aos franceses devido às diferenças étnico-culturais entre os grupos árabes e bereberes. Tal ação fracassou, os cabilas envolvidos utilizaram o armamento para a luta pela independência, fazendo com que a FLN conquistasse mais força beligerante. As forças argelinas computaram um milhão e meio de mortos argelinos, e, do lado francês, foram cerca de trinta mil. Os anos de luta pela independência argelina marcaram não só a população diretamente envolvida, deixando nela profundas marcas, mas também toda uma geração de intelectuais ${ }^{244}$, como o antilhano Franz

\footnotetext{
${ }^{244}$ Muitos intelectuais franceses, como Jean Paul Sartre, Simone de Beauvoir e Albert Camus (franco-argelino), apoiaram as forças argelinas contra o domínio colonial francês.
} 
Fanon $^{245}$, médico psiquiátra que viu de perto, nos hospitais argelinos, as vítimas das torturas do exército francês.

Após a independência, mais de um milhão de colonos franceses, chamados de pieds-noirs (pés negros), deixam a Argélia, constituindo um dos maiores êxodos da história recente. Ainda em 1962, o Governo Provisório da República da Argélia é derrotado pelo Exército de Libertação Nacional (ELN), braço armado da FNL. Ahmed Ben Bella passa a chefiar o novo governo, sob o comando da FLN, partido único socialista e populista, e proclama a Argélina como nação exclusivamente árabe, constituindo um duro golpe contra os grupos cabilas defensores de uma Argélia laica e democrática. Parte desses militantes berberes cai na clandestinidade e entra nas fileiras do partido Front des forces socialistes (FFS), pegando em armas contra o governo de Ben Bella. Outra parte do grupo berberista emigra para França, organizando lá a Academia Berbere (1967), reagrupando em território francês os militantes berberes. Essa Academia seria a primeira instituição berbere de cunho global, proporia um alfabeto standard tifinagh (de origem líbia-berbere) e criaria a famosa bandeira amazigh, com as cores: azul, representando o mar mediterrâneo; verde, as montanhas; e amarelo, o deserto do zaara; com a letra "Z" ao centro do alfabeto tifinagh que designa "homem livre" em amazigh.

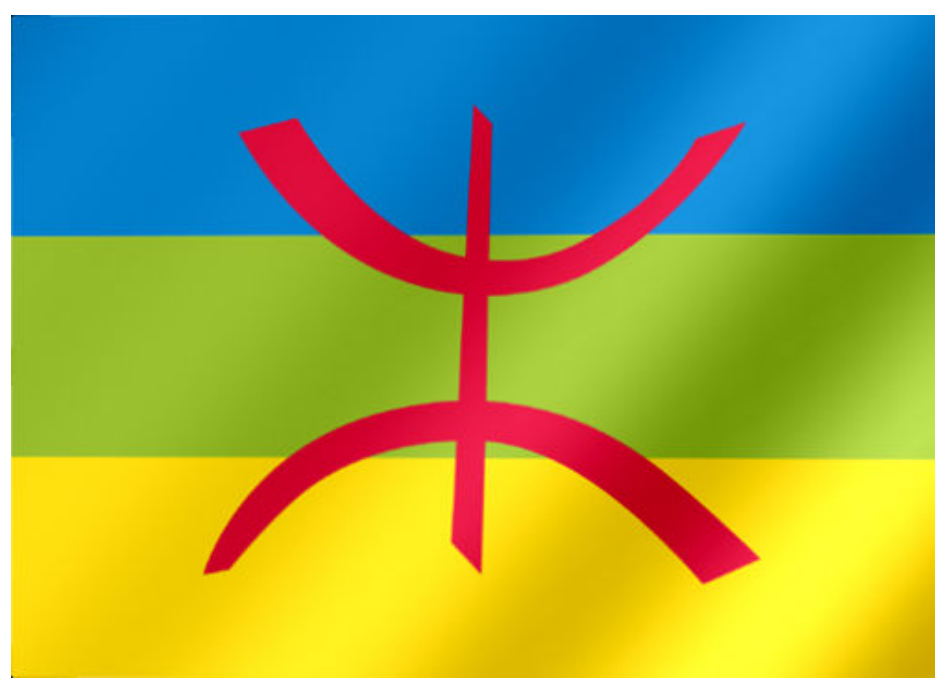

Figura 12 - Bandeira Amazigh

245 Sua obra Os condenados da Terra, de 1961, menciona diretamente as mazelas da guerra argelina impetradas pelo exército francês, tornando-se um manifesto contra o colonialismo europeu. Ao lado de seu livro anterior, Peles negras, máscaras brancas (1952), essa obra trouxe novas reflexões sobre o racismo como sistema complexo, propulsor da expansão europeia e do colonialismo. Ambas as publicações constituem as obras seminais para os estudos pós-coloniais, a crítica sobre a construção histórica, social e política do "Outro" (do não europeu) nos regimes coloniais e pós-coloniais. 
$\mathrm{Na}$ Cabília, em vários momentos o movimento berbere reivindicará a identidade linguística e cultural. Em 1973, uma grande repressão a uma greve estudantil na Universidade de Argel pelo direito ao ensino da língua berbere culminará em uma nova emigração em direção à França para a Universidade de Paris VIII - Vincennes, formando, assim, o Grupo de Estudos Berberes voltado ao ensino da língua e da cultura, com a publicação da revista Tisuraf. Nesse período, outras associações berberes (cabilas) foram organizadas em solo francês. Esse mesmo ano foi marcado pelo movimento dos cantores bereberes, clandestinos e militantes. Surgem, assim, os mais importantes e emblemáticos músicos ligados à militância berbere na Cabília. São eles: Idir (compositor da famosa música Vava inu va), Ferhat M'henni, Djamal Allam, Lounès Matoub, o grupo Djurdjura (LACOSTEDUJARDIN, 2005). A repressão violenta do governo argelino, com assassinatos, bombas, prisões, contra qualquer expressão berbere mostra a 'arabização' imposta em toda a Argélia contra qualquer expressão de diversidade linguística e cultural não árabe.

Na década de 1970, na Cabília, além dos grupos universitários, o clube de futebol JSK (Jeunesse Sportive de Kabylie), por imposição do governo nomeado JET (Jeunesse Électronique de Tizi-Ouzou), se tornou o principal núcleo vivo da identidade política cultural berbere na região. Em 1977, a reivindicação cultural berbere seria reconhecida por um partido político argelino: o Partido da Revolução Socialista (PRS), clandestino, de Mohamed Boudiaf. Sob a influência dos jovens berberistas Hocine Aït Ahmed, o PRS passa a defender a língua berbere como língua nacional.

A Argélia será governada por um partido único até 1988. Enquanto partido único, a FNL estruturou a economia do país de forma planificada, dependente da produção do petróleo, sob o comando de uma grande burocracia corrupta. Promoveu o que chamou de "arabização" do ensino, impondo o árabe como língua oficial do Estado. Com a crise dos preços do petróleo, em 1988, e o aumento da dívida do Estado e a explosão demográfica, esse modelo "argelino de desenvolvimento" entrará em crise, ocasionado uma forte pressão por reformas democráticas e pelo pluripartidarismo. 


\subsection{PRIMAVERA BERBERE E MOVIMENTO CULTURAL}

Em abril de 1980, após a proibição, por parte do governo argelino, de uma conferência do escritor Mouloud Mammeri sobre a poesia cabila antiga na Universidade de Tizi-Ouzou, houve o maior levante popular cabila de todos os tempos, reivindicando o reconhecimento da língua berbere (tamazight) como língua nacional. A manifestação se desenvolveu primeiro em torno da universidade, entre os universitários e os estudantes do Liceu Amirouche, depois seguiu-se uma grande manifestação fortemente reprimida pelo governo.

O governo argelino de bandeira árabe-islâmica taxou esse movimento como uma criação colonialista, embora as manifestações tenham tomado também a Universidade de Argel, ganhando a adesão dos trabalhadores das usinas Sonelec (de cidade de Draa Bem Khedda), a ponto de ocorrer a primeira greve geral desde a independência. Muitas pessoas foram presas e 24 foram condenadas pelas manifestações. Desde então, o dia 21 de abril de 1980 tornou-se uma data marcante e anualmente comemorada entre a comunidade cabila da Cabília e do mundo, que a chamou de Primavera Berbere (Printemps Berbere). Em agosto desse mesmo ano, no primeiro seminário sobre o Movimento Cultural Berbere e da Democracia, realizado na cidade de Yakouren, o grupo chega à conclusão da necessidade de promover o uso e o ensino da língua berbere e do árabe argelino, associando, assim, a língua árabe falada na Argélia (LACOSTE-DUJARDIN, 2005).

O movimento continuou no ano seguinte, outras associações culturais berberes foram criadas, levando a novas prisões em várias cidades cabilas e em Argel. Diante disso, o governo decide abrir quatro departamentos de cultura e dialetos populares nas universidades de Argel, Oran, Constantine e Annaba. Nos anos seguintes, novas manifestações, e, em 1985, se cria a Liga Argelina dos Direitos do Homem (Ligue Algérienne dês Droits de l'Homme - LADH), sendo alguns membros do quadro do Movimento Cultural Berbere (MCB). Durante a repressão, militantes e berberistas da LADH continuaram as manifestações na Cabília após a prisão dos cantores Ferhat M'henni e Lounis Aït-Menguellet. Nesse período, várias associações são criadas fora da Argélia (Tala, Afus deg Ufus, Abrida, ACB).

Em 1989, no segundo seminário do Movimento Cultural Berbere na cidade de Tizi-Ouzou, o grupo reafirma a defesa de um movimento democrático mais amplo 
para todo o povo argelino. A partir desse seminário uma parte de seus militantes funda um novo partido político: Rassemblement pour la culture et la démocratie (RCD), sob a direção de Saïd Sadi ${ }^{246}$. Nesse contexto, várias associações berberes nascem na Argélia, cabilas, chenoua, entre outras, bem como são fundados jornais em língua berbere. Enquanto o restante dos membros do MCB se recusa a se tornar um partido político, seus militantes se dividem em dois partidos cabilas existentes: RCD, de Saïde Sadi, e FFS, de Hocine Aït-Ahame ${ }^{247}$. Como resposta, o governo cria um departamento autônomo de língua e cultura tamazight na Universidade de TiziOuzou, em 1990, e depois, no ano seguinte, em Bejaïa. Novos espaços de ensino de tamazight se espalham em Alger, Tizi-Ouzou e Bejaïam, enquanto muitas associações de cultura berbere se expandem e animam as cidades falantes da língua tamazight.

No período entre 1991 a 1998, a Argélia mergulha numa intensa guerra civil, causando o óbito de aproximadamente cinquenta mil pessoas. Em decorrência das eleições multipartidárias de 1991, a Frente Islâmica da Salvação (FIS) consegue sair vitoriosa, defendendo a criação de um estado islâmico e questionando a opção democrática. Impedida de assumir o poder pelas forças políticas que defendiam a abertura da Argélia, a FIS pega em armas e torna-se o Grupo Islâmico Armado $(\mathrm{GIA})$, disseminando o terrorismo armado contra civis, principalmente mulheres, intelectuais, estrangeiros (sobretudo franceses) e vilarejos isolados.

Em 1995, é assinado um tratado de paz entre os principais partidos argelinos (FLN, FFS, FIS, entre outros) no intuito de diminuir a violência generalizada. Nesse mesmo ano, o governo argelino cria o Haut-Commissariat à L'Amazighitè (HCA), tornando a cultura berbere uma estratégia política indelével para a manutenção da estabilidade política na região. Tudo isso não impediu o aumento de grupos islâmicos extremistas contra essa efervescência berbere.

Em 1998 é assassinado Lounes Matoub, o importante músico, compositor e cantor cabila, morto em uma emboscada feita por um grupo extremista islâmico, até hoje ainda sem identificação dos culpados. Sua morte aconteceu em 25 de junho,

${ }^{246}$ Said Saadi (1947-), médico psiquiatra, fundou o Rassemblement pour la culture et la démocratie $(R C D)$. Considerado de centro-esquerda, defende a cultura cabila na Cabília, à favor do estado laico e contra as correntes islâmicas na região.

${ }^{247}$ Nascido em 1926, Hocine Aït Ahmed foi um dos chefes da Frente de Liberação Nacional (FLN), participando ativamente da luta pela independência argelina. Após a independência funda a Frente das Forças Socialistas (FFS). É exilado e retorna à Argélia 23 anos depois, em 1989. Desde, então, continua à frente do FFS. 
outra data lembrada e comemorada com homenagens à sua obra e sua militância ${ }^{248}$. Matoub era cabila, defendia a laicidade berbere e a identidade argelina. Considerava-se ateu e muitos apontam o próprio governo como mandante do crime, que, por sua vez, acusa os grupos islâmicos por considerá-lo um blasfemo, principalmente por causa da canção Allahu Akbar. De fato, ele é um dos maiores mártires cabila e berbere do mundo. Seu nome foi dado às ruas da cidade de Grenoble e Lyon (França). Várias de suas canções são verdadeiros hinos da identidade Cabila, amplamente difundida no Youtube e no DailyMotion ${ }^{249}$.

\subsection{PRIMAVERA NEGRA E GRUPOS POLÍTICOS CABILAS}

$\mathrm{Na}$ virada do século $\mathrm{XXI}$, vários conflitos violentos tomaram as ruas da Argélia, principalmente na Cabília, após o assassinato em 18 de abril de 2001 do estudante secundarista Massinissa Guermah por policiais. Os enfrentamentos deixaram um saldo de centenas de mortos e mais de duas mil pessoas feridas, sendo lembrados como a "Primavera Negra". Após essa data, a reivindicação berbere foi sendo abraçada ativamente pela juventude, no movimento dos aârch ${ }^{250}$, buscando, dessa forma, reativar algumas instâncias tradicionais fora dos partidos políticos, já bastante desgastados.

Segundo a historiadora Karina Direche-Slimani, a reascenção de valores identitários, apoiados nas formas "arcaicas" de organização política social cabila, estava somada não só a esse desgate dos partidos políticos, mas, principalmente, ao desemprego, à crise econômica, à falta de expectativas para os jovens cabilas na Argélia. Para ela, esse protesto popular ambicioso e original dos aârch mostrou «En court-circuitant les relais politiques traditionnels et en adoptant des pratiques de représentation politique puisées dans l'organisation sociale passée $d u$ monde

${ }^{248}$ Quando eu estive na França, durante o estágio do doutorado no exterior, tive a oportunidade de ir a duas manifestações culturais em homenagem à Lounes Matoub. Sua pessoa resplandece na expressão associativa ligada à identidade cabila e berbere na França. A data de seu falecimento tornou-se um evento de expressão de uma "berberidade" cabila, crítica, militante e profundamente multidentitária: berbere, cabila, argelina, laica.

${ }^{249}$ Site de busca de vídeos, similiar ao Youtube, muito popular na França.

250 Como vimos, aârch é uma unidade social tradional (tribu) composta por mais vilas vizinhas, com interesses políticos e administrativos em comuns. Depois da família, aârch é uma unidade social menor que a confederação (qabila ou taqbilt) (LACOSTE-DUJARDIN, 2005, p. 15). 
berbère, le mouvement des âarch propose une mobilisation et une dynamique de la contestation uniques dans l'histoire du Maghreb contemporain» (DIRECHESLIMANI, 2006, p. 111).

Essa forma original de assunção de uma identidade cabila tem em seu bojo as reivindicações políticas e as reformas profundas no sistema política argelino:

Le mouvement des âarch dépasse donc la stricte revendication identitaire. Si le déni identitaire pratiqué par l'État algérien depuis 1962, date de l'indépendance, renvoie au déni démocratique, il souligne également des dysfonctionnements politiques graves. $\grave{A}$ l'échelle de la Kabylie, la revendication kabyle renvoie au déficit de la représentation politique alimenté par des partis politiques plus sou-cieux de reconnaissance institutionnelle que de la prise en charge des problèmes matériels et humains de la région. À l'échelle de l'État algérien, c'est l'étroitesse de la marge de manœuvre de l'aile civile des dirigeants politiques qui apparaît une fois encore. Celle-ci, traversée par ailleurs par des rivalités complexes, ne semble pas disposer du pouvoir nécessaire pour imposer une autre gestion de la crise. Et surtout, elle est confrontée et/ou liée à une oligarchie militaro-financière qui contrôle les principaux rouages politiques et économiques. (DIRECHE-SLIMANI, 2006, p. 111)

Por conseguinte, é um movimento que problematiza a identidade nacional argelina, reinserindo nela, em um nível político, as especificidades culturais cabila:

Finalement, le mouvement des âarch est particulièrement significatif des enjeux de mémoire qui se nouent autour du passé dans l'Algérie d'aujourd'hui. Désillusions et réactivité d'une rare intensité, manipulations et nostalgies instrumentalisées d'une histoire idéelle, discours et pratiques politiques englués, aussi bien de la part des Berbères de Kabylie, que de l'appareil d'État, dans une conception de la communauté nationale qui renvoie à celle que E. Gellner, dans une définition anthropologique de la nation appelait "une communauté politique imaginaire et imaginée comme intrinsèquement limitée et souveraine». Enjeux symboliques mais aussi politiques autour d'un passé réaménagé pour récuser une doxa nationale qui ne profite qu'à ses représentants mais aussi pour affirmer un autre projet de société qui s'enracine dans une histoire jusque là dévalorisée sinon, oubliée. (DIRECHE-SLIMANI, 2006, p. 112)

Diante desse grande movimento, os agrupamentos sociais e políticos cabilas decidiram redigir uma plataforma comum de reivindicações. O governo argelino, de sua parte, buscou ganhar tempo para enfraquecer o movimento. Uma parte desses 
grupos cabilas se reuniu em torno de Belaïd Abrika ${ }^{251}$, no Mouvement pour l'Autonomie de la Kabylie (MAK), e, em 2003, conseguiu que o governo argelino declarasse a língua berbere (tamazight) como língua nacional. Entretanto, dois pontos se tornaram controversos: a exigência de um departamento de polícia Cabila e a supremacia civil sobre os militares. Tais pontos ainda hoje não são unânimes entre os próprios cabilas, que se dividem entre aqueles que buscam um diálogo com o governo e os dissidentes contrários a qualquer negociação.

Atualmente os grupos políticos que buscam o controle da Cabília são os Partidos Front des Forces Socialistes (FFS), de Hocine Aït Ahmed, e o Rassamblement pour la culture et la démocratie (RCD), fundado por Saïd Saadi e atualmente dirigido por Mohcine Belabbas ${ }^{252}$, além do Mouvement d'Autonomie de la Kabylie (MAK), de Ferhat Mehenni ${ }^{253}$, organizado principalmente por cabilas que vivem na França.

\subsection{A DIÁSPORA CABILA NA FRANÇA}

O termo "diáspora" tem origem no grego antigo (סıабторá - "dispersão") e refere-se ao deslocamento forçado ou voluntário de um povo ou grupo étnico no mundo, utilizado durante o helenismo para descrever a diáspora dos gregos no mundo, tendo sido utilizado para designar a diáspora negra e a diáspora judaica. Durante o século $X X$, a palavra foi utilizada para nomear a dispersão de outros povos, vindo a tornar-se um campo de estudo dos processos migratórios globais e

\footnotetext{
251 Nascido em 1969, na Argélia, atualmente é professor de economia da Universidade Mouloud Mammeri de Tizi-Ouzou. Fez parte do movimento estudantil e foi presidente dos conselhos do aârchs. É um militante político bastante atuante em defesa da autonomia da Cabília.

${ }^{252}$ Político argelino, atual presidente do RCD.

${ }^{253}$ Ferhat Mehenni (1951-) é cantor e ativista político. Estudou Ciências Políticas na Universidade de Argel na década de 1970. Lá teve contato com vários movimentos estudantis. Participou de festivais com sua banda "Imazighen" com referência à identidade berbere. Fez parte do MCB e do RCD. Fundador do Mouvement d'Autonomie de la Kabylie (MAK), é o atual presidente do Gouvernement provisoire Kabyle (2010). O grupo formado por cabilas na França não possui respaldo popular na Cabília para suas pretensões autonomistas.
} 
transnacionais ${ }^{254}$ e dos estudos culturais e pós-coloniais repercutidos nas obras de Arjun Appadurai, Homi Bhabha, Gayatri Spivak, Paul Giroy e Stuart Hall.

Para os estudos de fenômenos diaspóricos, o geógrafo francês Michel Bruneau considera que o «Espace et territoire de diaspora doivent être appréhendés d'abord dans les pays d'accuiel, où le lien communautaire joue le rôle essentiel, puis dans le pays ou territoire d'origine, pôle d'atrraction, à travers une mémoire, enfin à travers le système de relations dans l'espace-réseau qui relie ces différents pôles» (BRUNEAU, 2004, p. 24). Ou seja, o estudo da diáspora presume a análise dos laços comunitários (no país atual) e da memória (do país de origem), por meio do "espaço-rede" que conecta esses polos. Partindo desse pressuposto, busquei analisar a diáspora cabila na França e a digital por meio da incursão nesse "entrelugar" (BHABHA, 1998) entre os laços comunitários e a memória conectada pelas redes digitais, aquilo que Diminescu (2010) chama de migração conectada, "ediáspora".

Os primeiros fluxos migratórios argelinos e cabilas para a França são registrados desde 1905. O sociólogo argelino Abdelmalek Sayad (1999) ressaltou que a emigração cabila evidenciou o subdesenvolvimento econômico e os desequilíbrios das estruturas tradicionais e rurais. Esses fluxos foram impulsionados para suprir a mão de obra nas indústrias automobilística, siderúrgica e de sabão, principalmente em Marselha, em minas de carvão e no Exército Francês. No final da Primeira Guerra Mundial, em 1918, havia, na França, cerca de quarenta mil trabalhadores e dez mil soldados cabilas, recrutados e voluntários.

Em 1950, nas comunidades cabilas, um a cada três homens havia imigrado para a França, sendo $50 \%$ dos imigrantes argelinos eram cabilas (Lacoste-Dujardin, 2005, 2006). Foi uma migração, sobretudo, masculina, de homens solteiros que buscavam trabalho para juntar dinheiro com o objetivo de ajudar suas famílias na Cabília. Em princípio, as famílias cabilas organizavam as viagens desses jovens à França para uma curta temporada. Em seguida, essa migração se tornou a dos homens que trabalhavam durante um período maior. Durante a guerra pela independência argelina, algumas mulheres cabilas, "pioneiras", passaram a fazer parte desse contingente migratório (LACOSTE-DUJARDIN, 2005).

\footnotetext{
${ }^{254}$ Os processos migratórios transnacionais decorrem dos processos globais que, ultrapassando as fronteiras nacionais, delineam espaços transfronteiriços, tanto situados entre os espaços de origem quanto os de acolhida.
} 
Em 1975, sob a pressão de aumento do desemprego, a "migração de trabalhadores", de homens solteiros, foi proibida ${ }^{255}$, enquanto o reagrupamento familliar foi somente autorizado aos parentes de famílias trabalhadoras, de trabalhadores e comerciantes, que tiveram filhos na França ${ }^{256}$, ajudando a estabilizar esse agrupamento.

De fato, essa imigração cabila não se restringiu ao suprimento de mão de obra trabalhadora na França, seu contingente era formado também por uma elite de comerciantes, de empreendedores, de profissionais liberais e intelectuais.

Na década de 1970, a imigração cabila já se encontrava estabilizada e com fortes vínculos com a Cabília. «[...] les Kabyles de France ont toujours maintenu la solidarité villageoise et le contact avec le pays, souvent regroupés chez de mêmes employeurs comme dans de mêmes quartiers, correspondant avec la famille demeurée en Kabylie et retournant en vacances au village» (LACOSTE-DUJARDIN, 2006 , p. 108). De alguma forma, todos os acontecimentos relacionados ao movimento berbere na Argélia, na região da Cabília, tiveram alguma relação com os grupos imigrantes na França, principalmente pelo fato de eles se organizarem em

255 Embora a diáspora cabila na França seja a mais importante e destacada por causa da sua expressão numérica e pelo seu comprometimento com as questões políticas e culturais em sua terra natal, ela também ocorreu em outras partes do mundo em menor número: Europa, Reino Unido, Bélgica, Países Baixos, Alemanha e Itália; e em outros países: Nova Caledônia, Síria, Austrália, Estados Unidos e, sobretudo, com um contigente mais numeroso, na região do Quebec, no Canadá.

${ }^{256}$ Até então (1945-1965), a imigração de trabalhadores das ex-colônias era encorajada pelo governo francês para suprir a mão de obra nos setores mais estratégicos da economia. Depois, se tornou um problema mais que econômico, com custos sociais, mas ameaçador para uma identidade francesa. A imagem do trabalhador imigrado, potencial ocupante de um posto de trabalho de um cidadão francês, passa a ser "substituída por uma visão dos imigrados como grupos portadores de um projeto coletivo ameaçador" (POUTIGNAT e STREIFF-FERNAT, 1998, p. 15), principalmente associado aos grupos islâmicos. Essa mudança de representação presencia o deslocamento das questões urbanas ligadas à imigração. Se o conflito nas periferias representava uma luta e uma divisão entre franceses e imigrados, esses espaços urbanos tornavam-se cada vez mais palco de segregação socioétnica, surgindo novos atores urbanos definidos e visíveis, sobretudo, pelas revoltas violentas e incontroladas contra o Estado e a sociedade francesa (POUTIGNAT e STREIFF-FERNAT, 1998). O endurecimento dessas representações e tensões sociais coincide com os debates em torno do modelo francês de integração, baseado, até então, em um suposto laço "indissolúvel entre os aspectos jurídicos e culturais da 'naturalização' do estrangeiro" (POUTIGNAT e STREIFF-FERNAT, 1998, p. 16), garantida na Constituição francesa, que proíbe qualquer tipo de diferenciação entre seus cidadãos seja por sua origem, 'raça' ou religião. Tal modelo contrasta com o estadunidense de reconhecimento oficial à diferença étnica. Contudo, assiste-se a uma crescente diferenciação das categorias jurídicas entre "franceses" e "estrangeiros" e as categorias operantes nas relações sociais. Na França, tal tema é um debate sensível, recorrente e controverso em suas diversas esferas: jurídica, política e social. Vide a proibição do uso do véu por mulheres muçulmanas em espaços públicos, controvérsia que ocasionou muitas discussões em torno de um multiculturalismo na sociedade francesa. 
associações culturais berberes muito ativas em solo francês e com fortes vínculos identitários e políticos com sua terra natal.

Atualmente, a comunidade alcança aproximadamente um milhão de imigrados de origem Cabila, compreendendo os próprios imigrantes, seus familiares e seus descentes. Segundo Lacoste-Dujardin (2005, p. 187), «L'immigration kabyle constitue une elite, kabyle et française, qui, tout em militant activement pour la sauvegarde de la culture kabyle dans toutes sés expressions et sous toutes ses formes (langue, littérature, arts plastiques, graphiques et musicaux, etc), participe pleinement à la vie citayenne.» (LACOSTE-DUJARDIN, 2005, p. 187). Estima-se que metade dos cafés parisienses pertence a proprietários de origem cabila.

Para Lacoste-Dujardin, a colonização francesa produziu vários efeitos complexos, contraditórios e imprevistos, e, no caso da Cabília, ela contribuiu diretamente para a renovação cultural berbere tanto na Argélia quanto na França. Existe uma efervescência da expressão cabila entre sua juventude, presente nas asssociações e atividades políticas, culturais, pedagógicas (cursos de dança, língua, conferências seminários) e festivas; também nas mídias, nos jornais, publicações, rádio, TV (Berèbe Television) e, no digital, nos sites e em várias redes sociais digitais.

Para a pesquisadora Karina Direche-Slimani (1997), as novas gerações de imigrantes cabilas realizam um novo fenômeno de reapropriação da cultura e da identidade berbere. Ao mesmo tempo, tal fenômeno não se contrapõe ao processo de integração à sociedade francesa: «tient un discours très valorisant sur sa culture d'origine, tout en prônant une totale adéquation aux valeurs de la Ille République. Comme si, en se réappropriant son origine, on se donnait les moyens de mieux réussir son intégration». Dessa forma, a imigração cabila na França, para a autora, constituiu: «un terrain privilégié d'expression identitaire, un lieu de travail culturel intense et de combat politique très actif» (DIRECHE-SLIMANI, 1997, p. 198 apud LACOSTE-DUJARDIN, 2006, p. 97).

Assim, o 'caso cabila' contradiz o efeito clássico do processo pós-colonial ${ }^{257}$, no qual os fluxos imigratórios poderiam representar algum tipo de 'fratura colonial' no seio da sociedade francesa ou modalidades de relações subalternas ou a adoção de

${ }^{257}$ O processo pós-colonial diz respeito tanto ao fim do colonialismo quanto à leitura crítica e histórica associada a uma geração de pensadores dispostos a refletir sobre seus efeitos. Alguns autores dos estudos culturais fazem parte desse grupo, como Stuart Hall (2003) e Homi Bhabha (1998). 
um discurso de vitimização presente nas reivindicações de reparação. Ao contrário, a renovação da identidade cultural cabila por essa juventude expressa um "múltiplo pertenciamento étnico" (no geral, eles se autoidentificam simultaneamente cabilas, berberes e franceses e, em alguns casos, cabilas, berberes, argelinos e franceses).

En effet, loin de s'en tenir à cultiver des rancœurs, la plupart de ces
fils et filles d'anciens colonisés venus de Kabylie se projettent dans
une démarche doublement positive: non seulement ils s'activent
dans l'urgence à la sauvegarde de leur riche patrimoine culturel,
exprimé dans cette langue distincte de l'arabe, le berbère
(ou tamazight), dans sa variante kabyle(taqbaylit), mais encore ils
contribuent à son enrichissement et à son développement dans de
nouvelles formes artistiques, exprimant ainsi leur "multi-
appartenance, ethnique, sociale et culturelle... comme une source de
richesse individuelle et collective " dans une "identité métisse "
[Belaidi, 2003]. (LACOSTE-DUJARDIN, 2006, p. 97)

Este multipertencimento representa uma situação muito própria das diásporas (HALL, 2003), que reinscrevem suas referências identitárias decorrentes de processos tradutórios desses espaços-redes. Certamente, essa especificidade cabila insere-se nos desdobramentos da colonização francesa na Argélia, onde a dominação e a violência imposta a esse povo deixaram marcas fortes e profundas nas relações entre os dois países e na própria imagem da imigração argelina na França ${ }^{258}$.

Após essa breve exposição histórica do fluxo migratório cabila para a França, é possível resumir as feições dessa diáspora. Em primeiro, o começo desse fluxo deu-se pelo incentivo dado à administração colonial para suprir uma demanda de mão de obra, ocorrendo, assim, a emigração de homens solteiros. Em 1975, as barreiras migratórias são instituídas e o governo francês permite somente o reagrupamento familiar, instituindo uma nova configuração na comunidade cabila na França. Houve também os casos de exílio de políticos e intelectuais. De lá para cá, essa população cabila e seus descendentes construíram laços comunitários associativos, com uma forte consciência identitária ligada não só à memória do seu território de origem, mas à sua presença física esporádica nessa sociedade.

\footnotetext{
${ }^{258}$ No geral, os argelinos são vistos pela sociedade francesa como "árabes", os próprios cabilas são invisibilizados por esse termo. Tal imagem estigmatizante não está desvencilhada de um rancor oriundo do conflito pela independência. Na literatura sobre a diáspora cabila na França, costuma-se referir-se à percepção francesa sobre eles como distinta da sobre os argelinos. Essa "diferença" decorre da identificação dessa comunidade com os valores laicos e republicanos franceses.
} 
Nesse tipo de diáspora ${ }^{259}$ (BRUNEAU, 2004), a rica vida comunitária no país atual reinventa uma memória compartilhada, criando uma comunidade imaginada (ANDERSON, 2006), ao mesmo tempo muito atuante em seu país de origem. Essa "conexão", a manutenção e a reinvenção dos laços associativos só são possíveis pelo fator tecnológico associado às novas tecnologias da comunicação e informação. Por ser uma diáspora sobretudo comunitária (CHIVALLON, 2004 apud BRUNEAU, 2004), as associações imazighen e cabilas na França, aproximadamente cinquenta, segundo dados não oficiais ${ }^{260}$, objetivam principalmente o intercâmbio cultural nas suas mais diversas expressões: musicais, festivas, literárias. Essa característica será muito marcante na configuração da ediáspora cabila, isto é, na sua transformação digital nas redes interativas que analisaremos no capítulo seguinte.

\footnotetext{
${ }^{259}$ A partir de uma vasta revisão bibliográfica, Bruneau difere quatro elementos fundamentais das diásporas: 1) a dispersão motivada por catástrofe; 2) a escolha do país dá-se pela existência de um fluxo migratório e o motivo é trabalho; 3 ) a população migrante, sem se integrar, conserva uma consciência identitária mais ou menos forte ligada à memória do seu território de origem ou de sua sociedade. Neste tipo, explica-se uma vida comunitária rica no país atual, reinventando, a partir de uma memória compartilhada, uma comunidade imaginada (ANDERSON, 2006); 4) por último, os grupos imigrantes dispersos na sociedade atual desenvolvem entre eles e a sua sociedade original relações em escalas múltiplas, em forma de redes, com relações mais horizontais que verticais. Ainda recorrendo ao número quatro, ele classifica quatro tipos de diásporas: 1) a econômica, que envolve a busca de oportunidades, de trabalho (diáspora chinesa, indiana, libanesa); 2) a religiosa, associando à língua um elemento estruturante (diáspora judaica, grega, armena); 3) a diáspora política, motivada pela disputa territorial (palestinos, tibetanos, etc.); 4) a diáspora em torno do polo racial e cultural (diáspora negra).

260 Tive acesso a uma lista de 45 associações ou grupos imazighen na França por meio da pesquisadora Ângela Collado, pesquisadora da cultura amazigh no Marrocos. (ver Anexo 7) Durante a pesquisa, encontei outras cinco associações por meio das redes digitais, entretanto, não consegui localizar dados oficiais sobre essas organizações (quantos e quem são).
} 


\title{
CAPÍTULO 6
}

\section{KABYLE.COM: A E-DIÁSPORA}

\begin{abstract}
Ces technologies nous servent à améliorer nos supports éducatifs (cartable interactif pour l'écolier berbère ghiles Ikni par exemple) mais elles vont surtout rapprocher les peuples sur des problématiques communes et recréer des alliances identitaires ( « tectonique des espaces antiques imaginaires, rêvés ou idéalisés») bassin libyco-basque tel que perçu Joseph Henriet. Une e-diplomatie parallèle des peuples peut voir le jour où la nation kabyle sera correctement représentée.

L'enjeu actuel c'est d'être présent et pris en compte par ces logiciels open source (traductions), les webservices, les evn numériques (démultiplier l'offre en vidéos à la demande), être représentés dans les banques d'images notamment celles liées

à l'actualité, créer nos propres agences de communication et d'imagerie, intensifier l'usage du mobile en tamazight premier support de communication direct.
\end{abstract}

Stéphane Arrami, entrevista de 27 de julho de 2012.

A dimensão transnacional da transformação cultural migração, diáspora, deslocamento, recolocação - torna o processo de tradução cultural uma forma complexa de significação. O discurso natural(izado), unificador, da "nação", dos "povos" ou da tradição "popular" autêntica, esses mitos incrustados da particularidade da cultura, não pode ter referências imediatas. A grande, embora desestabilizadora, vantagem dessa posição é que ela nos torna progressivamente conscientes da construção da cultura e da invenção da tradição.

Homi Bhabha (1998, p. 241)

Neste capítulo, seguindo a proposta desta tese, percorro as associações e as disseminações do deslocamento nas redes digitais dos cabilas/berberes. Ingressamos de vez, aqui, nas dobras dessa diáspora pela porta de ingresso de sua incidência reticular e digital, nas tramas da complexa arquitetura informativa do Kabyle.com. Para isso, este capítulo está dividido em cinco partes interagentes: a primeira, relativa à explicação conceitual da "e-diáspora", fruto de um debate produzido no interior dos estudos migratórios intrísecos às análises dos processos comunicativos digitais, que engendram qualitativas transformações na 'natureza' da própria imigração contemporânea. 
Na segunda parte, passo a comentar os acontecimentos que me levaram a escolher esta experiência, mostrando, assim, os fatores contingentes inerentes, e, muitas vezes, determinantes na pesquisa e em qualquer campo do conhecimento. Essas teias invisíveis são alinhavadas nos encontros acadêmicos, capazes de efetivar o início de uma pesquisa no espaço de enunciação de seus resultados científicos. Meu deslocamento a Tunis para a participação em evento científico permitiu-me - reticularmente e por meio dos fluxos informativos, pelos encontros e pelas redes - localizar a experiência cabila na e-diáspora.

$\mathrm{Na}$ terceira parte deste capítulo, discorro sobre minha incursão nos circuitos da e-diáspora cabila, a pesquisa preliminar de associações e sites da diáspora e meu encontro com atores-redes que me ajudaram a transitar nos espaços diaspóricos cabilas em Paris. Na quarta parte, chego até o portal Kabyle.com. A partir de uma descrição das partes de composição do site e dos comentários de Stéphane Arrami, seu desenvolvedor, idealizador e redator, teço uma reflexão pontual sobre essa experiência, perscrutando os fluxos informativos dessa arquitetura informativa digital.

Finalmente, na quinta e última parte, reflito sobre seus significados, primando pela semântica da tríade simbiôntica, da forma comunicativa do habitar da ediáspora cabila.

\subsection{E-DIÁSPORA}

Como vimos no capítulo anterior, a diáspora tem por conotação primordial o deslocamento ou a dispersão de um grupo para o mundo. Essa condição repercute em uma permanente reconstrução de um território simbólico comunitário e identitário, por meio do qual os laços sociais entre seus membros se redefinem no país atual. Com a emergência das redes digitais - suas linguagens multimidiáticas e suas espacialidades interativas, a diáspora ganha uma nova conotação em seus aspectos identitários, sociais e espaciais. No caso dos cabilas, a língua tamazigh e o patrimônio de seus repertórios culturais são constantemente reivindicados, fundamentando o discurso político de uma parcela dessa população herdeira dos movimentos de reconhecimento da cultura berbere (amazigh). 
Ao contrário dos sintomas de uma "fratura social", essa população diaspórica é marcada por um multipertencimento (eles se sentem berberes, cabilas, franceses, argelinos). A especificidade cabila nos mostrou que o próprio colonialismo produziu as circunstâncias para o fortalecimento e a renovação da identidade berbere na Cabília, com a difusão da escolarização (e a apropriação da escrita na transcrição da tradição oral por parte de seus intelectuais) e com a emigração (LACOSTEDUJARDIN, 2006). Esse campo diaspórico cabila assumiu uma nova significação com o advento das redes sociais digitais e com as arquiteturas informativas (sites, blogs, microblogs, redes sociais, etc.). É por essa feição "digital" intrísenca às diásporas atuais que a combinação dos elementos interagentes culturais, territoriais, tecnológicos e comunicativos transformam-se em propulsores da efervescência cultural e da conexão com seus territórios, fazendo também das redes digitais novas espacialidades comunicativas, semânticas, associativas e culturais.

A relação entre mídia e processos diásporicos vêm sendo analisada nos últimos anos por inúmeros estudiosos (APPADURAI, 2001; HALL, 2003; DIMINESCU, 2010). Os estudos específicos sobre as culturas berberes (ALMASUDE, 1999; BOUZIDA, 1994; EL MOUNTASSIR, 2001) já sinalizam o impacto qualitativo dos dispositivos comunicativos anteriores à Internet, no desempenho do importante papel de comunicação e manutenção dos laços entre aqueles que partiram e os familiares que ficavam. As famílias, impossibilitadas de escrever cartas aos seus parentes por serem analfabetas, registravam suas mensagens com o uso de gravadores de voz, criando uma nova forma de comunicação e vínculo entre as comunidades diaspóricas. Esse foi um fenômeno comum e significativo entre as comunidades imazighen do Marrrocos e da Argélia.

When cheap portable audiocassette recorders came on the market, they began to replace the reel to reel tape decks and the record players. Cassette recorders provided Moroccans not only with the option to record and play their favorite music, but also to utilize them as a form of communication on a mass scale. The illiterate emigrants in Europe found the audiocassette recorders useful in corresponding with their family members. Instead of paying a stranger to write for them a letter to their families in Morocco, emigrants could now simply push a button and talk to the audiocassette recorder. When finished, they sent the tape back home, and the family gathered around to listen and respond individually or as a group. The family members in Morocco could share with the emigrant in Europe their activities, including religious ceremonies and family celebrations. (ALMASUDE, 1999, p. 120) 
Se os estudos sobre os processos migratórios apontavam os traumas, as perdas, as oposições e as rupturas com seus laços originários, representando o designado pelo sociólogo Abdelmalek Sayad como "dupla ausência", classificando o fenômeno da imigração como uma relação de dominação - um sujeito ausente de seu país de origem e não reconhecido, não integrado e estigmatizado no seu país atual. Com o surgimento e a proliferaração de tecnologias de informação e comunicação, tal interpretação perdeu sentido argumentativo. Diante da web 2.0, das redes digitais, de uma ecologia cognitiva (LEVY, 1993), aparece com intenso vigor o que a socióloga fraco-romena Dana Diminescu chamou de "migração conectada" ou "e-diáspora" «ce migrant connecté s'inscrit ainsi plutôt dans une logique de continuité (et non pas de rupture) qui permet de se trouver ici et là-bas, seul(e) et ensemble en même temps, etc.» (DIMINESCU, 2010, p. 11).

Tal abordagem realizada pela socióloga advoga por uma "presença conectada", associada a essas novas tecnologias de comunicação, que problematizam as categorias produzidas pela sociologia das migrações nesse novo contexto da ecologia digital ${ }^{261}$ :

L'évolution des pratiques de communication a certainement introduit le plus important des changements dans la vie des migrants, depuis les simples modalités "conversationnelles» où la communication supplée à l'absence, jusqu'aux modalités "connectées» où les services entretiennent une forme de "présence» continue, malgré la distance.

Mais la connectivité dont est sujet le migrant n'est pas seulement liée à la communication à distance. Elle se diversifie au fur et à mesure que son environnement de vie et de mobilité se numérise. Par conséquent, les questions classiques de la sociologie des migrations telles que le passage des frontières, les flux, l'intégration, les regroupements familiaux, le développement et le transfert d'argent,

261 "E-diáspora" nomeia também o projeto coletivo coordenado pela socióloga Diminescu, integrado à Maison Sciences de L'Homme, no Grupo TIC/Migrations, objetivando construir arquivos Web sobre imigração e inovar as ferramentas metodológicas de pesquisa - as conceituais, como a transição da mobilidade, a conectividade e tracibilidade; e as metodológicas propriamente ditas, como o uso de softwares, serviços móveis e de mobilidade espacial, além do estudo etnográfico do comportamento de mobilidade e comunicação. Procura, assim, uma solução híbrida de investigação (pesquisa qualitativa e uso de dispositivos para traçar o rastro dessa mobilidade). Tive a oportunidade de participar do seminário de apresentação dos resultados da pesquisa "Homeland Connections: E-diaspora Atlas / A Century of Transnationalism" (Paris, 23 a 25 de maio de 2012). No evento foi lançado o "e-Diaspora Atlas", oito mil sites observados em suas interações e arquivos, com seus resultados combinados em diversos suportes (mapas impressos, aplicações para smartphones e sites). Para mais informações ver: http://www.e-diaspora.fr. 
etc., se voient revisitées dans le nouveau contexte de l'écologie digitale. (DIMINESCU, 2010, p. 15)

Este "migrante conectado" está aqui e lá, inserido em uma hipermobilidade tecnológica, comunicativa e digital. Se a mobilidade acarreta uma continuidade espacial, compartilhamento simbólico em sua percepção de "estar com", na diáspora "conectada" cabila há simultaneamente uma renovação do laço comunitário e da identidade cultural cabila. Além da "presença conectada", a conexão entre o território de origem e o atual, com a potencialização de sua mobilização nos metaterritórios, permite a essas populações migrantes conectadas a desterrritorialização e a reterritorialização em espaços "outros", incidindo na pluralização de suas localidades. Essa e-diáspora constitui-se também pelas novas possibilidades de registro e proliferação do rico patrimônio cultural desses povos, reintroduzindo dinâmicas ligadas às tecnologias de comunicação e às informações imprevisíveis, que pouco se ajustam ao sentimento de perda "cultural", como enunciado por Pierre Bourdieu ao tratar das transformações das estruturas tradicionais da organização política e imaterial (principalmente da poesia) cabila.

Essas novas dinâmicas estabelecidas pelas interações tecnológicas frustram as percepções de cultura cabila/berbere estática, relegada à ideia do 'tradicional' como depósito nostálgico de um passado puro, autêntico e incontaminado. Ao contrário, os atores-redes cabilas diaspóricos e conectados estão associados na contingência das interações com os dispositivos técnicos. Lançam, assim, novas possibilidades de retraduções e reelaboração de seus repertórios culturais, efetivando novas significações sobre o devir da cultura amazigh e cabila.

Through Amazigh-net, the different groups of Imazighen began to perceive themselves as one community and the question of Thmazight is no longer that of debating the existence of an identity separate from that of the Arabs, as Shafiq argued. Members of different groups log on daily to discuss not only the urgent situation of Thmazight and Imazighen, but also the plans for the implementation of Thmazight in education, technology, and science. (ALMASUDE, 1999, p. 124)

Isso nos remete diretamente ao conceito de cultura anteriormente discutido por Marchesini (2010) como processo comunicativo e hibridizante com as alteridades não humanas. Ainda, nos reporta a um tipo de ecologia imbricada nos 
agenciamentos técnicos, nas interfaces digitais e nas operações técnicas para a memória.

\begin{abstract}
A digitalização permite a passagem da cópia à modulação. Não haveria mais dispositivos de "recepção", mas sim interfaces para a seleção, a recomposição e a interação. Os agenciamentos técnicos passariam a assemelhar-se com os módulos sensoriais humanos que, da mesma forma, também não "recebem", mas filtram, selecionam, interpretam e recompõem.

[...] Uma infinidade de circuitos informativos, pessoais, pertencendo à oralidade arcaica, continuará a irrigar as profundezas da coletividade. Ainda que processada por novos métodos, uma grande parte da herança cultural continuará. [...]

Mas os dispositivos materiais em si, separados da reserva local de subjetividade que os secreta e os reinterpreta permanentemente, não indicam absolutamente nenhuma direção para a aventura coletiva. Para isto são necessários os grandes conflitos e os projetos que aos atores sociais animam. Nada de bom será feito sem o envolvimento apaixonado de indivíduos.

[...] As técnicas agem, portanto, diretamente sobre a ecologia cognitiva, na medida em que transforma a configuração da rede metassocial em que cimentam novos agenciamentos entre humanos e multiplicidades naturais [...]. (LÉVY, 1993, p. 130-131)
\end{abstract}

Essa combinação heterogênea dos agenciamentos técnicos, dos circuitos informativos digitais e de suas modulações, das paixões desses atores-redes cabilas, da ecologia cognitiva dessa coletividade humana e não humana, estão no âmago da e-diáspora cabila-berbere.

De um lado, por sua interação com as tecnologias digitais, a e-diáspora conseguiu promover a internacionalização da questão da cultura Imazighen e o reconhecimento dessas identidades por parte de alguns dos estados nacionais (no caso do Marrocos e da Argélia). Como vimos no processo histórico vivenciado pelos cabilas, a questão da cultura Amazigh vem sendo reivindicada dentro dos espaços políticos na Argélia ${ }^{262}$, mas, sobretudo, naquela espacialidade comunicativa digital sem a qual a cultura, a língua e todo seu patrimônio seriam ainda invisíveis e estariam destituídos da possibilidade de novas interações interculturais por meio das redes digitais.

\footnotetext{
${ }^{262}$ Somente em 2003 essa questão identitária passou a ser um movimento de autonomia regional, com o MAK e o GAK, mas ainda é uma questão bastante controversa entre os cabilas. Não há consenso sobre essa reivindicação territorial. Até então havia uma reivindicação de uma berberidade dentro do universo nacional argelino e, com o crescimento da repressão do governo argelino-árabe, foi-se constituindo uma tensão em direção ao fim do diálogo e à busca de uma autonomia regional sob a regionalização da identidade amazigh naquela cabila.
} 
Portanto, buscamos aqui repensar, a partir de uma perspectiva da complexidade, reticular, parcial e situacional (MORIN, 2001; DI FELICE, 2009, 20112012), uma nova condição habitativa e simbiôntica dessa experiência diaspórica, baseando-nos em suas associações (LATOUR, 2012) enquanto "e-diáspora" conectada (DIMINESCU, 2010), reticular e ecológica.

\subsection{ANTECEDENTES DA PESQUISA}

Como mencionado no segundo capítulo, minha conexão com a experiência cabila nas redes digitais aconteceu após meu encontro com Ângela Collado, doutoranda em ciências políticas da Universidade Autônoma de Madrid e pesquisadora da atuação dos povos Amazigh do Marrocos nas redes digitais. Conheci Collado no evento 3ème Rencontre du Programe de Recherche de I'IRMC ${ }^{263}$, em Tunis, na Tunísia, em abril de $2012^{264}$. A proposta do encontro foi discutir os movimentos sociais on-line, o ciberativismo e essas novas formas de expressão no Mediterrâneo. Participei desse evento como ouvinte por causa do meu envolvimento com a pesquisa "Net-ativismo - ações colaborativas e novas formas de participação em redes digitais", desenvolvida no Centro de Pesquisa Atopos, no qual eu havia produzido um artigo com os resultados parciais da pesquisa sobre a Rede Povos da Floresta, analisando-a como um tipo de "netativismo ecossistêmico" ${ }^{\prime 25}$. Na época desse encontro com Collado, me encontrava em um dilema. A "Rede Sardinia People", a rede social da Sardenha que eu havia selecionado inicialmente para comparação, estava fora do ar, impossibilitando a

\footnotetext{
${ }^{263}$ Institut de Recherche sur le Maghreb Contemporain (IRMC).

${ }^{264} \mathrm{Na}$ época, o que mais me motivou a participar desse evento foi a possibilidade de conhecer Tunis, a capital da Tunísia, palco do primeiro levante contra um governo autoritário, iniciando o que ficou conhecida como "Primavera Árabe", uma série de manifestações populares em países árabes contra seus regimes autoritários. Na Tunísia, em dezembro de 2010, um jovem vendedor de frutas ateou fogou ao próprio corpo como forma de protesto contra a corrupção e o desemprego no país. Depois desse ato deseperado que levou à sua morte, todo o país foi às ruas manifestar-se contra o governo. Tais manfestações causaram a derrubada do governo de Zine El-Abdine Ben Ali, no poder desde 1987, e depois se espalharam pelos países árabes.

265 Título do artigo: "Mídias nativas digitais e net-ativismo ecossistêmico - o caso da Rede Povos da Floresta", publicado nos anais do IV Simpósio Nacional de Pesquisadores em Cibercultura. Rio de Janeiro, 18 a 21 de novembro de 2010.
} 
continuidade da pesquisa. Após trocarmos e-mails, Angel Collado me repassou algumas referências bibliográficas e o endereço do site do Kabyle.com.

De lá, de abril a julho de 2012, imergi nos circuitos da rede cabila, especificamente no portal ${ }^{266}$ Kabyle.com. Paralelamente, consultei a bibliografia relativa à história e à cultura desse povo, apresentada no capítulo anterior, como fonte de apoio para a compreensão desse circuito informativo. O objetivo, como já mencionado na parte II desta tese, era argumentar sobre a Rede Povos da Floresta, e não o estudo da cultura cabila, mas o de suas intersecções/interações entre seus elementos culturais, midiáticos digitais e territoriais. Assim, mergulhei nas associações de seus atores-redes, buscando, por meio da tríade simbiôntica, refletir a semântica do local digital das culturas em sua forma "diaspórica". Antes de qualquer coisa, essas interações simbiônticas envolvem minhas interações com esses circuitos, transcendendo qualquer tipo de análise distanciada sobre essas experiências. Meu contato com as redes diaspóricas e com o portal Kabyle.com, bem como o contato com seus militantes e suas culturas, ocorreu primeiramente nas redes digitais. Habitei nesses circuitos, fui aos seus eventos reterritorializados, conheci os militantes berberes-cabilas em Paris e tive a oportunidade de conhecer pessoalmente o desenvolvedor e editor do Portal Kabyle.com, Stephane Arrami. Dito isso, reescrevo, nas páginas seguintes, os rastros dessa experiência.

\subsection{NOS CIRCUITOS DA E-DIÁSPORA CABILA - PESQUISA PRELIMINAR}

A busca preliminar no Google, utilizando a palavra "kabyle" (em francês), nos oferece 1.720 .000 resultados $^{267}$ (04 de maio de 2012). Um número impressionante, mesmo que dentro desse universo nem tudo se refira às arquiteturas informativas digitais produzidas pelos mesmos. Um dado importante: a primeira referência no resultado dessa busca é o site "Kabyle.com", sobre o qual decidi me debruçar para rastrear os significados da digitalização da diáspora cabila. Os motivos já citados anteriormente devem-se ao fato de o Kabyle.com ser o portal informativo cabila-

\footnotetext{
266 O portal, dentro da conceituação da arquitetura da informação, tem foco nos seus públicos, criando espaços de interação (chats, fóruns, sistema de busca no próprio site, etc.) com seu público. Obviamente, aqui o termo "público" é pouco adequado, pois sua arquitetura informativa permite a interação direta por meio do espaço para comentários em cada um dos posts publicados. Seria, assim, um "público ativo", pois emite opinião sobre os conteúdos postados.

267 Também busquei utilizando o nome cabila "taqbaylit", com 3.060 resultados (04 de maio de 2012).
} 
berbere mais conhecido e importante, produzido por uma equipe formada de colaboradores e militantes presentes na França, no Canadá, na Tunísia e na Cabília (Argélia).

Antes de nos adentrarmos na descrição propriamente dita do Portal, apresento o mapeamento preliminar ${ }^{268}$, o qual nos permite vislumbrar a diversidade da atuação da diáspora cabila nas redes digitais:

http://tameddurt.com/

Site em língua tamazight com a biografia de personalidades berberes que marcam seu tempo. Disponível somente na língua tamazight.

http://www.tinmel.net/kabylefacile/

Site de ensino da língua berbere. Disponível em francês.

http://idlisen.com/

Uma espécie de vitrine de livros e revistas berberes prestes a ser integrada a um serviço de venda on-line. Disponível somente na língua tamazight.

http://imedyazen.com/

Site oficial da Associação cultural Imedyazen na Argélia. Disponível somente na língua tamazight.

http://apulee.com/

Site da Associação Apulee que divulga seus trabalhos de salvaguarda da memória oral cabila-berbere.

http://www.taqbaylit.com/

Site dedicado ao ensino da língua berbere em Glèbe Collegiate Institute, Ottawa. Disponível somente na língua tamazight.

http://studiodoublevoice.com

Site de importante estúdio de dublagem cabila. Disponível em francês.

http://ayamun.com/

Revista literária berbere. Disponível somente na língua francesa.

http://imyura.net/

Site de literatura berbere. Disponível somente na língua tamazight.

http://aghucaf.wordpress.com

Blog do escritor Malek Houd, poeta cabila. Disponível somente na língua tamazight.

http://tamazgha.fr/

${ }^{268}$ Parte dessa lista me foi fornecida por Brahim Slimani, presidente da Associação Berbere-Cabila Apulee. 
Site da Associação Tamazgha (Paris). Este site, ao lado do Kabyle.com, é um dos mais importantes dos povos berberes. Atualidades, história e notícias sobre esses povos.

http://www.bylka.fr/dossier.php?bylka=ajkf

Site da Association des Jeunes Kabyles de France (Associação dos Jovens Cabilas na França). Site com várias informações sobre shows, concertos, atividades do grupo associativo.

Não existem dados específicos e oficiais sobre o nível de conexão dessas populações (seja na Cabília, na Argélia ou na França), do tipo que possamos inferir como e onde eles obtêm o acesso à internet (domicílio, trabalho, locais públicos, etc.). Observei o uso muito difundido, entre essa comunidade na França, de dispositivos móveis (celulares) com acesso à rede. São oferecidos pacotes com telefone (com direito a chamadas internacionais gratuitas para telefones fixos), internet e canais de TV por assinatura relativamente baratos se comparados com os preços praticados no Brasil. Há uma ampla difusão de "Internet Point", locais com acesso à Web, a preços módicos. Além disso, em Paris existe uma rede wi-fi pública e gratuita.

A descrição da arquitetura informativa da Kabyle.com diferiu-se daquela que realizei com a Rede Povos da Floresta pelo fato de a primeira apresentar uma dinamicidade e complexidade informativa, com frequentes atualizações, que me impediu de "narrar" todos seus conteúdos interativos.

$\mathrm{Na}$ imersão preliminar em outras arquiteturas informativas digitais cabilas tive a ajuda de Brahim Slimani (ver Anexo 5), berbere, cabila, argelino que atualmente mora em Paris. Nascido em 1968, em Boudjellil, Argélia, engenheiro mecânico de formação, Slimani é presidente da Association Apulee ${ }^{269}$, comprometida na divulgação da cultura berbere-cabila, na qual ele e um amigo cabila que está no Canadá fazem um trabalho de salvaguarda da memória e das narrativas orais cabilas, por meio de entrevistas gravadas com os detentores desses saberes. A

\footnotetext{
${ }^{269}$ Apulee refere-se à Lucius Apuleius (Apuleio), nascido em Madura, Argélia, C. 125, de origem berbere, estudou gramática, retórica, poesia e filosofia. Sua obra mais famosa é Metamorfose (Metamorpheseon), ou o Asno de Ouro, as aventuras de Lucius, transformado em um asno por acidente.
} 
associação possui um site em tamazigh, com informações relativas ao patrimônio cultural berbere e à política local na Argélia ${ }^{270}$.

Conheci Brahim Slimani no evento em solidariedade à M. Haddadene, músico cabila em tratamento com hemodiálise, em Paris. Realizado no dia 23 de junho de 2012, no restaurante Au Café de Paris (158 rue d'Oberkamp, Paris) ${ }^{271}$, organizado pela Associação cabila Tacemlit, esse evento contou com a participação dos músicos, cantores e cantoras: Tenna, Myriam, Houria, Yelas, Yiwn Sin, Tighri Usar, além do próprio homenageado. Foi minha primeira interação com o mundo berberecabila fora do circuito digital ${ }^{272}$, tendo chegado a esse evento por meio das redes digitais. Vi o anúncio no portal Kabyle.com e no perfil de Kahina Slimani ${ }^{273}$, uma das duas mulheres participantes da equipe editorial do portal à época.

No evento, chamou-me a atenção, além da explosão de cores e sonoridades, a forte participação de mulheres, além de homens, de todas as faixas etárias. Nesse café tipicamente francês, de propriedade cabila, há uma antiga sala de espetáculos ao fundo. No palco, diversas mesas e cadeiras ocupadas por famílias berberescabilas rendiam uma interessante reterritorialização híbrida de corpos, sonoridades, línguas. A cada apresentação de canto as mulheres entoavam o youyous, o grito típico das mulheres cabilas-berbere, reverbendo uma transgressiva e múltipla composição performativa de suas identificações e temporalidades.

Em uma canção que lembrou os mortos da Primavera Negra na Cabília evento importante na memória desse povo, mencionado no capítulo anterior algumas pessoas foram tomadas pela emoção. Abriu-se um silêncio comovente e Houria, a cantora, sob o tablado com os olhos levemente fechados e com uma das mãos sobre o estômago, conectava-se à memória coletiva, como todos que ali estavam.

${ }^{270}$ Como eu não conheço a língua tamazigh, analisar essas arquiteturas era um empreendimento inviável.

${ }^{271}$ Como mencionado anteriormente, $40 \%$ dos cafés parisienses são de proprietários de origem cabila. É também o espaço principal de socialização dessa comunidade na França, lugar primordial onde se realizam encontros, festivais e shows.

272 Também pude fazer meus primeiros registros audiovisuais, disponíveis no blog http://localdigitaldasculturas.wordpress.com/.

${ }^{273}$ Minha primeira tentativa de aproximação com a equipe do portal foi com Kahina Slimani. Deixei uma mensagem em seu perfil no Facebook, apresentei a pesquisa e a mim, convidando-a para uma entrevista no próprio Facebook. Não obtive nenhuma resposta. À época eu pensava que se me aproximasse de uma mulher seria mais fácil. Na prática foi o contrário, os homens demonstraram mais disponibilidade para conversar sobre o assunto. Nesse sentido, ajudou-me a condição de brasileira, ocasionando uma empatia imediata. O fato de eu ser "estrangeira" e estar pesquisando a experiência cabila também era visto com simpatia por eles. 
Esse instante infinito e irruptível, profundamente estranho para mim, estava muito próximo daquilo que Walter Benjamim (1994, p. 224) chama de rememoração (Eingedenken), que reintegra épocas, superando a distância temporal e espacial aos juntar as ruínas da história num tempo absoluto, contrangendo presente e passado a uma nova conexão: "A verdadeira imagem do passado perpassa veloz. O passado só se deixa fixar, como imagem que relampeja irreversivelmente, no momento em que é reconhecido". Uma abertura para o novo, uma nova confrontação com o mundo histórico, procedimento oposto a uma história construída pela consecutividade de causas e efeitos.

Naquele momento, compreendi que a força associativa cabila na diáspora emana dessa forma de rememorar não só a violência impetrada contra eles durante vários momentos da sua história, mas a capacidade de reelaborar de forma vibrante um rico patrimônio cultural, com grande carga de significação e emoção para aqueles que o compartilham.

Do grupo, Brahim Slimani era o único que estava com a bandeira Amazigh, acompanhado de sua irmã e uma amiga. Sentadas próxima a mim, comecei a conversar com elas, e, ao comentar que era brasileira (meu sotaque era evidente) e estava fazendo uma pesquisa sobre a diáspora cabila nas redes digitais, imediatamente fui apresentada a ele. A partir desse encontro por acaso, Brahim Slimani se transformou em meu principal interlocutor, meu "informante", embora tal termo me incomode por recorrer a uma assimetria disjuntiva. Posso dizer que Brahim Slimani me inseriu no mundo cabila em Paris e também em suas redes digitais, já que me passou outras indicações de arquiteturas informativas digitais em tamazigh, já citadas, feitas por aqueles em situação de diáspora. Após aceitá-lo em meu perfil do Facebook ${ }^{274}$, passei a observar ${ }^{275}$ também "seus amigos", boa parte militantes da causa berbere/cabilas. Com comentários e vídeos em tamazigh e francês, os temas mais debatidos entre eles são assuntos relacionados à política e à afirmação da identidade berbere e cabila em vários contextos do Magrebe.

\footnotetext{
${ }^{274}$ Brahim Slimani tem o número impressionante de 4.974 amigos (02 de julho de 2012) e centenas de fotos, muitas com a bandeira Amazigh.

${ }^{275}$ Interagi nesse circuito com frequência semanal durante o mês de julho de 2012.
} 


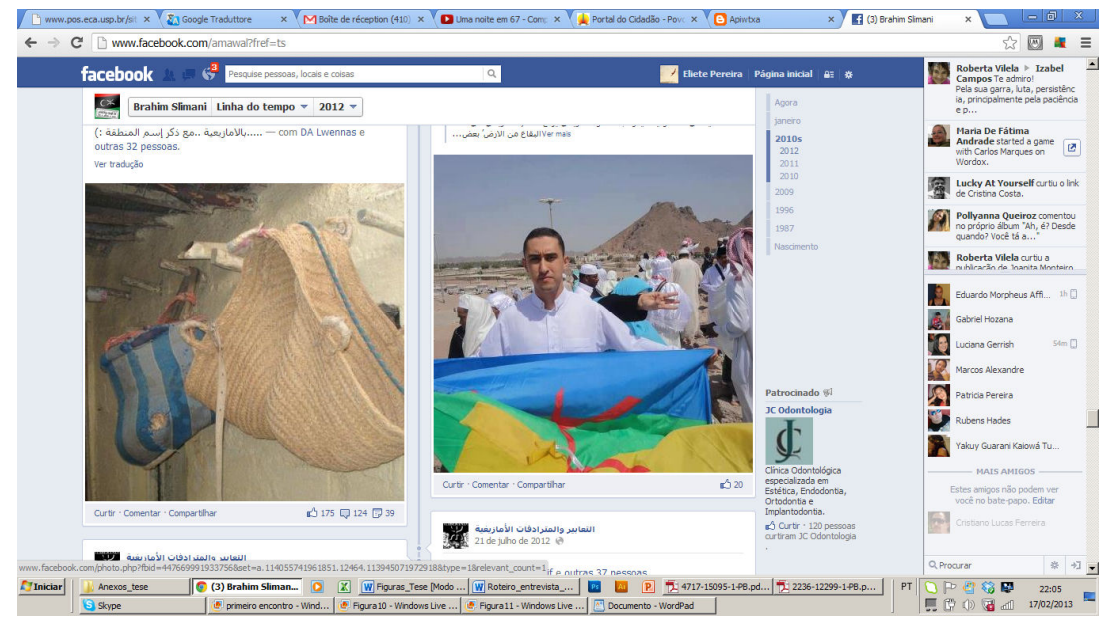

Figura 13 - Perfil de Brahim Slimani no Facebook

$\mathrm{Na}$ oportunidade de dialogar sobre essa experiência com Brahim Slimani, ele considera que, além de reforçar os laços comunitários e associativos, divulgar os eventos promovidos por suas associações e por outros grupos, as redes digitais permitem estabelecer uma rede de solidariedade entre a comunidade. Mobilização de capital social essencial àquelas pessoas ou famílias em situações vulneráveis, como o caso do cantor M. Haddadene, para o qual se organizou a atividade com a finalidade de ajudá-lo em seu tratamento médico.

Além desse evento, também participei das seguintes atividades em Paris, promovidas e divulgadas pela comunidade cabila/berbere nas redes digitais:

24/06/2012 - Homenagem à Lounes Matoub, na Praça Trocadero (dia 25 de junho é aniversário da morte do famoso cantor). Foi um evento com apresentação de cantores e grupos musicais, organizado pela Associação dos Jovens Cabilas da França (Association des Jeunes Kabyles de France);

30/06/2012 - A convite de Brahim Slimani participei de mais um evento em homenagem a Lounes Matoub, na periferia de Paris (Montmorency), promovido por uma associação cabila local. Estavam presentes aproximadamente duzentas pessoas, famílias, homens, crianças, idosos, sobretudo mulheres de todas as idades. Foram realizados shows, bingo, esquetes e muitos discursos. Nesse evento, por intermédio de Brahim conheci várias pessoas, entre elas uma senhora de aproximadamente setenta anos que teve dois filhos mortos na Argélia durante a Primavera Negra.

04/07/2012 - Conferência do escritor tunsino-canadense Hédi Bouraoui, de passagem pela França, onde falou sobre seu livro Paris Berbère. (ver Apêndices 13 
e 14). O evento ocorreu na sede da Associação Taferka (Montreuil, Paris). Lá conheci pessoalmente Stéphane Arrami, do portal Kabyle.com, que estava de passagem por Paris e, com isso, consegui realizar a entrevista via e-mail (ver Anexos 6 e 8$)$.

07/07/2012 - Manifestação em protesto à invasão de grupos extremistas islâmicos na região de Azawad, em Mali, onde habitam os Touaregs, povos imazihen (berberes). Lá conversei com outros colaboradores do portal Kabyle.com. Nesse evento havia vários representante do Mouvement pour l'autonomie de la Kabylie (MAK) e do Gouvernement provisoire Kabyle (GPK), entre eles seu presidente, o político e cantor Ferhat Mehenni. (ver Anexos 11 e 12)Nesse evento, fui fotografada por Stephane Arrami, tornando-me também tecno-imagem nos circuitos informativos digitais.

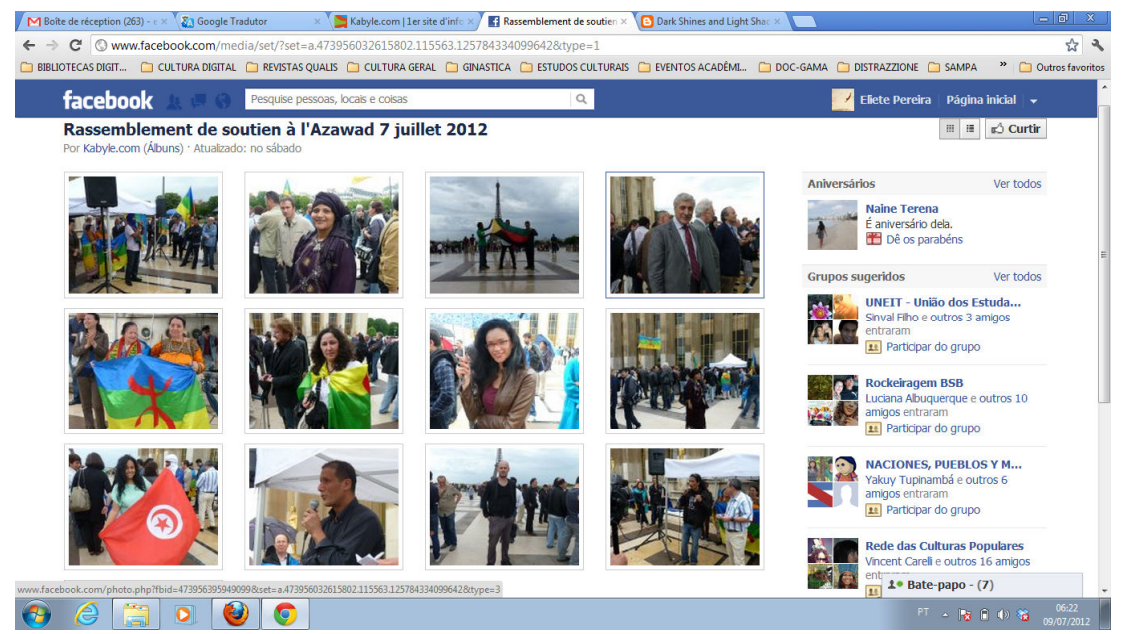

Figura 14 - Captura das fotos da página do Kabyle.com no Facebook - manifestação em defesa do território Azawad (Mali) em Paris, 07/07/2012 (Estou na segunda linha, terceira coluna) 


\subsection{NOS CIRCUITOS DA E-DIÁSPORA - KABYLE.COM}

Criado em 1997 por uma equipe de profissionais da comunicação cabila na França, depois editado pela Association Kabyle-France-Internacional (AKFI) ${ }^{276}$, tornou-se o principal portal de informação cabila e berbere em tempo real. Representa também a principal arquitetura de informação da diáspora cabila no mundo, conectando suas comunidades dentro e fora da Cabília. Por conta da sua complexa arquitetura informativa, com frequência diária de atualização, optei por uma estratégia de descrição diferente da realizada com o site da Rede Povos da Floresta. Ao invés de relatar a arquitetura reticular do conteúdo de cada parte (dos menus, links, ícones, etc.), decidi comentar suas atribuições gerais. Por ser um portal informativo atualizado e interativo, o conteúdo segue essa mesma dinâmica, correspondente aos acontecimentos mais evidentes ${ }^{277} \mathrm{e}$ à participação dos internautas.

Também aqui não realizei uma cronologia das suas associações, como fiz com a Rede Povos da Floresta. Por não ser um "projeto de conexão", mas uma arquitetura informativa digital que divulga as notícias mais atuais sobre a cultura berbere-cabila no mundo e promove o debate entre essa comunidade, existe, portanto, uma centralidade na rede informativa digital. A RPF divulgava suas ações no site; no kabyle.com, a digitalização responde à conectividade realizada pelas pessoas que queiram participar desse debate, os temas publicados obviamente são aqueles que interessam e repercutem na comunidade cabila no mundo e na própria Cabília.

${ }^{276}$ A associação inscreve sua atuação no campo intercultural, socioeducativo e cidadã, com o objetivo de favorecer, na França e no exterior, o reconhecimento da cultura e da língua cabila/berbere nas novas tecnologias de informação na mídia cabila e no site Kabyle.com. $O$ interessante é que essa Associação nasce depois do portal, assumindo, assim, a divulgação da cultura cabila nas novas tecnologias comunicativas como uma estratégia principal.

277 No período da pesquisa, dois eventos importantes ocasionaram um grande debate no portal: o primeiro foi a polêmica em torno da posição do famoso cantor Takfarina que, conhecido em todo o mundo cabila, declarou apoio à participação da população cabila nas eleições argelinas municipais em maio de 2012. O segundo evento, menos polêmico, envolveu as atividades relacionadas às comemorações ao cantor Lounés Matoub. 


\subsubsection{Origens e equipe editorial}

Editado pela Association Kabyle-France-Internacional (AKFI) desde 1998, o portal foi criado por Stéphane Arrami como Trabalho de Conclusão do Curso de Comunicação no Institut de la Communication - Université Lumière Lyon 2, em 1997, nos primeiros anos da Internet. Stéphane Arrami é um importante ator-rede da e-diáspora cabila na França. Idealizador do portal, reúne em sua atuação dois elementos marcantes, uma formação em desenvolvimento de sites e um perfil empreendedor na área de comunicação.

Seu interesse em divulgar a cultura berbere veio da pesquisa de suas raízes familiares cabila aos 14 anos, quando morava em Tunis (Tunísia) ${ }^{278}$. Enquanto morou lá, dos seis aos dezenove anos, produziu um jornal junto com um amigo tunisino-russo ligado ao club Jeunes la Presse. Segundo ele, para além de uma ligação sentimental com a Cabília, sempre sonhou em montar uma empresa de comunicação associada a um empreendimento cultural. A ideia do portal surgiu no intuito de transferir e continuar, nessa arquitetura informativa digital, o boletim cultural associativo berbere impresso em que trabalhava com seu amigo tunisinorusso antes do serviço militar ${ }^{279}$.

A passagem para o digital vem por meio, portanto, de uma mídia precedente, a impressa, ao passo que ele se aprofundou no desenvolvimento de sites, associando-se não só às organizações culturais e políticas da diáspora cabilaberbere, mas também discutindo a questão do "código" do open source, voltado ao desenvolvimento de plataformas interativas na Web. Arrami é um membro atualmente do Drupal ${ }^{280}$, um framework de gerenciamento de conteúdo, uma plataforma de site dinâmica open source (código aberto, livre, grátis), que permite a usuários individuais ou comunidades publicar, gerenciar e organizar uma grande variedade de conteúdo. O Drupal integra muito recursos populares de sistemas gerenciadores de conteúdo, blogs, ferramentas colaborativas e software de comunidades baseada em discussões em um único pacote. É um projeto de código

\footnotetext{
${ }^{278}$ Após a "Insurreição de 1871", na Cabília, contra a colonização francesa na Argélia, as terras de muitas famílias foram confiscadas pelo exército francês, levando a um grande êxodo de tribos cabilas para a Tunísia.

${ }^{279}$ O serviço militar na França era obrigatório até 2011.

${ }^{280} \mathrm{http}: / /$ drupal.org/
} 
aberto mantido e desenvolvido por uma comunidade em rede, uma espécie de inteligência coletiva e conectiva envolvida no desenvolvimento de soluções para o gerenciamento de conteúdos de arquiteturas informativas digitais. Recentemente, Arrami passou a ser o gerente da empresa Citywizz Communication ${ }^{281}$, criada para encontrar soluções em arquiteturas informativas digitais para empresas, e o portal Kabyle.com está no portfólio de experiências bem-sucedidas. Temos aqui uma curiosa combinação de atuação cultural, comunicativa e empreendedorismo digital $^{282}$.

No início, o Portal foi hospedado no Webcity. $\mathrm{fr}^{283}$. Segundo Stephane Arrami, essa hospedagem lhe permitiu "fundá-lo sob bases" sólidas. Apoiando-se em sua pequena rede constituída por uma rádio local cabila em Lyon e pelo Congrès Mondial Amazigh ${ }^{284}$, eles puderam construir uma arquitetura informativa base: um chat (bate-papo) ${ }^{285}$, páginas onde se poderia encontrar pela primeira vez um calendário berbere com fotos exclusivas de personalidades, informações, músicas cabilas traduzidas e entrevistas. À época, havia pouca informação da Cabília (ARRAMI, 2012) 266 $^{286}$. Depois do assassinato do cantor Lounes Matoub (25 de junho de 1998), as entrevistas realizadas com o partido Rassemblement pour la culture et la démocratie (RCD) e com outros grupos políticos da Cabília e personalidades (como o jogador Zidane, de origem berbere), e as reportagens sobre os grupos de solidariedade com a Cabília, o portal foi reconhecido pela primeira vez como site da diáspora cabila.

${ }^{281}$ Ver: http://www.citywizz.com/

${ }^{282}$ Em conversa com Brahim Slimani, ele mencionou a difusão de compra de "domínios" de nomes de cidades na Cabília. Tornou-se um bom negócio comprá-los com um valor muito pequeno e depois revendê-los para quem estivesse interessado. Uma espécie de ocupação e especulação do "território" digital. Por exemplo, Stephane Arrami me disse que antes de criar o portal já havia comprado o domínio "kabyle.com", ou seja, o endereço. É importante ater-se à estrutura dos sites, considerando que todos seguem a seguinte formação: "Protocolo://rede.domínio. tipo de domínio.país". Por exemplo: http://www.kabyle.com, "kabyle" é o domínio, ".com" é o tipo de domínio. Quando não há o país (por exemplo, os sites do Brasil são identificados pelo ponto br) é porque o domínio foi registrado nos Estados Unidos, que, sem a referência direta a um país, Ihe confere um caráter global.

${ }^{283}$ Webcity.fr, na época, era um provedor de hospedagem, onde Stephane Arrami trabalhou na sua fase embrionária.

284 O Congrès mondial amazigh (CMA), criado em 1995, é uma organização internacional não governamental independente de governos ou partidos políticos, que reagrupa associações socioculturais e de desenvolvimento imazighen, bem como da Tamazgha (África do Norte) que da diáspora berebe. Com o objetivo de defender e promover os direitos, os interesses políticos, econômicos, sociais, culturais e linguísticos da nação amazigh internacionalmente. Ver site: http://www.congres-mondial-amazigh.org/-/index.php.

${ }^{285}$ Logo em seus primeiros anos, o bate-papo foi desativado por inatividade. As pessoas preferiam participar dos fóruns, segundo Arrami.

${ }^{286}$ Entrevista realizada por e-mail com Stéphane Arrami. 
Para Arrami, o portal tem essa premissa de manter a ligação com o mundo fracofônico, cabila, berbere, laico, aberto aos debates e à reflexão sobre a cultura e política cabila-berbere. A meta, desde o início, que ainda não se cumpriu, segundo ele, é de o Portal se tornar um grande centro de informações com seus escritórios, antenas, em muitas cidades da África do Norte, cobrindo todos os países do Magrebe.

Nos últimos anos, ele e sua equipe vêm trabalhando persistentemente para isso. Desde 2003 o Portal é uma Société à responsabilité limitée (SARL), ou seja, uma empresa registrada. Sem apoios institucionais (públicos ou privados) ${ }^{287}$, conseguem manter o portal com a venda de espaço publicitário e de CD's, livros e outros produtos, presentes na loja virtual (que gera um lucro aproximado de mil euros anual). Segundo Arrami, as despesas com taxas de hospedagem e de manutenção do portal são de aproximadamente 3.500 euros por ano. Não há lucros, mas ele acredita que no futuro possam adquirir uma autonomia que cubra as despesas dos correspondentes nas regiões do Magrebe, multiplicando o espaço publicitário e inaugurando uma WebTV, sendo uma plataforma mista, com lógicas comerciais e open source ${ }^{288}$.

$\mathrm{Na}$ época em que pesquisei o site (abril a julho de 2012$)^{289}$, a rede de redatores estava organizada nas seguintes localidades e atribuições: Stéphane Arrami (Lyon), administrador e comité de redação e webmaster (desenvolvedor do site); Benamghar Rabah (Tigzirt), comitê de redação, correspondente local,

${ }^{287}$ Algumas associações berbere-cabilas apoiam "moralmente". Na Cabília, uma empresa aparecer no Portal pode constituir um risco econômico (por causa do conflito com os árabes-argelinos), paradoxalmente, a Cabília Ihes oferece mais possibilidade de se diferenciarem de outros sites. A divulgação de notícias da região faz com que eles tenham novos internautas e usuários do portal, aumentando a atração de investidores para pagar pela publicidade no portal. Não existe a modalidade "notícia paga" no Portal, eles buscam manter uma independência que lhes dê uma credibilidade entre a comunidade berbere-cabila.

288 O Kabyle.com se tornou um membro efetivo do Drupal, sendo o patrocinador do Drupal Camp em Lyon (cidade sede oficial do Portal). A ideia é que o trabalho realizado por eles no Portal se direcione para o oferecimento de serviços web como forma de diversificar o empreendimento e manter a autossustentabilidade do portal. A criação do Citywizz Communication é justamente para isso, diversificar o negócio, oferecendo a criação de sites para empresas ou quem quer que seja utilizando plataformas open source, com código aberto.

${ }^{289} \mathrm{Na}$ última pesquisa ao Portal, em 10 de janeiro de 2012, a equipe estava assim organizada e apresentada: Equipe de redação: Stéphane Arrami, editor chefe (Lyon); Rabah Bem Amaghar, Redator chefe da Região Tigzirt (Cabilía); Mourad Hammami, jornalista Tigzirt (Cabilía); Samia Ait Tahar, journalista, militante associativo Tizi-Ouzou (Cabilía); Tassadit Ould Hamouda, da Associação Tafsut (Montréal); Merzouk Ouchene, Redator chefe Tamazight; Dalil Makhloufi, responsável pelas informações de solidariedade Cabília. Recursos de informação: Rachid Diril (Lyon) - Dalil Makhloufi (Lyon). Equipe técnica: Stéphane Arrami, desenvolvedor e administrador do sistema, Jp Koziol, administrador do sistema. Responsável pela SARL, publicidade e vendas na loja berbere: Stéphane Arrami. 
moderador do fórum; Tassadit Ould Hamouda ${ }^{290}$, da Associação Tafsut (Montréal), comitê de redação, correspondente local e colaborador; Youba Amazigh (Bgayet), comité de redação, correspondente local; Mohandh (Paris), comitê de redação, correspondente local e colaborador; Dalil Makhloufi (Lyon), administrador, comité de redação e responsável pelas informações de solidariedade Cabília; Kahina Slimani (Courbevoie), correspondente local e colaboradora; HamidS (Tizi-Ouzou), correspondente local; Samia Ait Tahar (Tizi-Ouzou), comitê de redação, correspondente local; Tariq Amnay (Tizi-Ouzou), comitê de redação, correspondente local.

A equipe é recrutada também via Portal, por isso, as mudanças constantes em seus colaboradores. Qualquer um pode publicar matérias, desde que estas sejam aprovada pelo comitê de redação (há uma revisão entre pares). São remunerados somente os correspondentes na Cabília, em média paga-se quinze a vinte euros por matéria, e dez euros por uma nota breve, o restante do grupo é voluntário. Em média, cada membro da rede de redatores publica duas matérias por mês.

As informações obtidas localmente são a diferença do Portal, que divulga fatos ocorridos na região da Cabília por meio de correspondentes diretos, uma maneira de atrair novos usuários e internautas da diáspora que busquem informações específicas sobre a região, sem o filtro feito pelos jornais argelinos. $80 \%$ dos conteúdos publicados são produzidos pelo que ele chama de "jornalistas acionários" do portal: Arrami (responsável pela parte internacional e África do Norte), Arezki Baki (responsável pela cobertura da diáspora cabila) e Mourad Rabah (supervisor da equipe de redação da Cabília e diretor da futura webtv). Outras arquiteturas informativas foram agregadas ao Portal, como o feed RSS ${ }^{291}$, o Twitter e o Facebook ${ }^{292}$, tendo este último se tornado um campo de prospecção de matérias a serem publicadas, com base na rede cabila/berbere existente nessa rede social. $\mathrm{A}$ página do Kabyle.com no Facebook serve também para divulgar as novas matérias postadas. Assim, a interface do portal com o Facebook e o Twitter ajuda a irradiar as matérias e notícias atualizadas. O fluxo da informação é contínuo entre esses

\footnotetext{
${ }^{290}$ Segundo Arrami, Tassadit Ould Hamouda é um dos mais antigos e fiéis colaboradores do Portal. Contribui espontaneamente com entrevistas e matérias desde 2004.

${ }^{291}$ Feed RSS é um serviço que informa ao usuário inscrito as novas atualizações do site.

292 A página do Kabyle.com no Facebook tem 7.930 "curtidas", com fotos da Cabília e vídeos de músicas. Última verificação: 14 de janeiro de 2012.
} 
circuitos, e a conta do Kabyle.com no Twitter ${ }^{293}$ foi considerada, em 2012, uma das trinta mais influentes na Argélia.

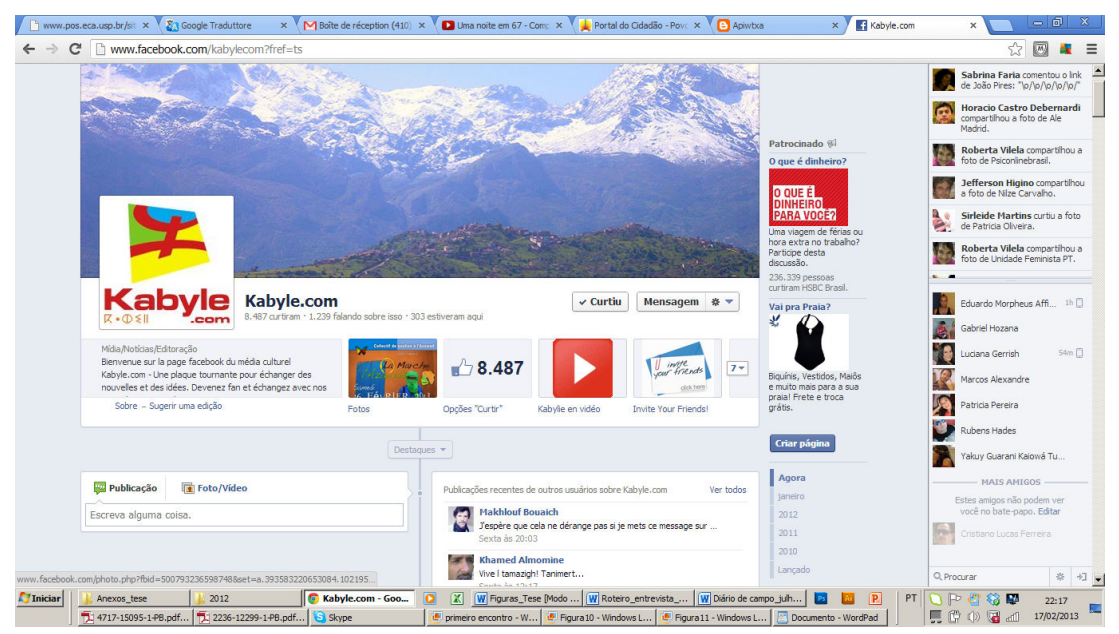

Figura 15 - Página do Kabyle.com no Facebook

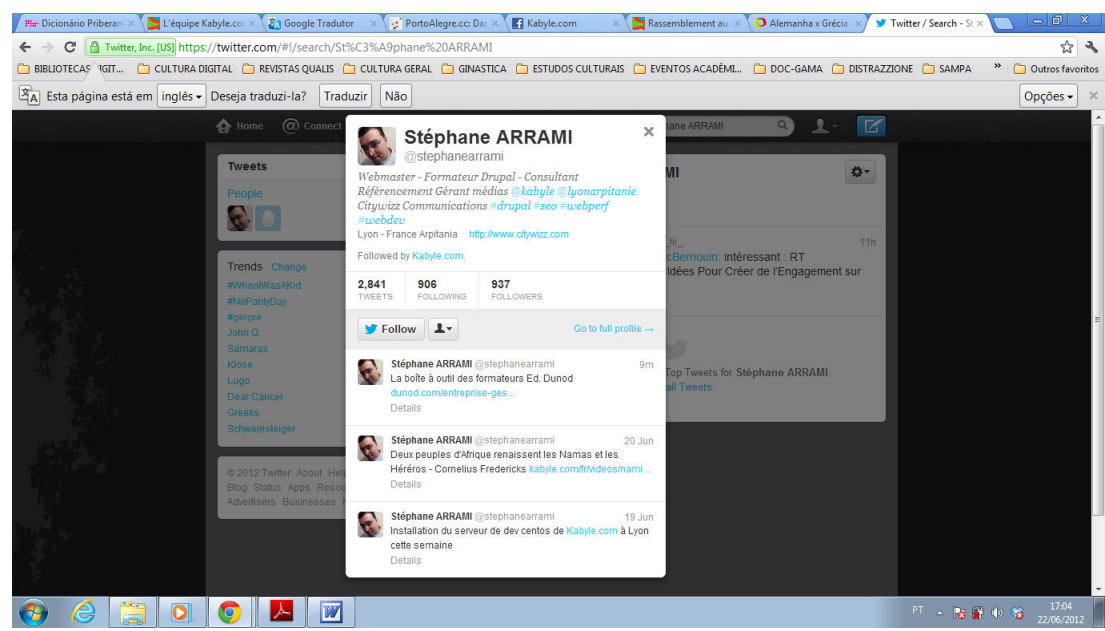

Figura 16 - Conta do Kabyle.com no Twitter

Se essa equipe editorial descentralizada e colaborativa pareceu-me uma forma ideal de se trabalhar em e na rede e, sendo possível assim fazê-lo pelos inúmeros aparatos comunicativos digitais (e-mail, skype ${ }^{294}$, Facebook, etc. ${ }^{295}$, o

293 A conta no microblog Twitter do Kabyle.com possui 2.285 seguidores, que acompanham suas atualizações, segue 223 perfis, totalizando 5.623 tweets (mensagens enviadas por eles). Data da verificação: 10 de janeiro de 2012.

294 Skype: software de comunicação pela internet por meio de conexões de voz e vídeo sobre IP (VoIP). Desde 2011 pertence à Microsoftware.

295 Por causa dos problemas com a conexão na Cabília, os correspondentes de lá enviam as matérias por e-mail, em seguida postadas no Portal. O restante da equipe de redação publica diretamente, valendo-se de suas plataformas de atualização do Drupal. 
processo de publicação no site ocorre também de forma a se buscar um consenso entre a equipe. Em relação ao processo de elaboração das matérias, há um padrão em toda notícia divulgada - apuração das fontes e cobertura de eventos in loco - e uma busca de realização de "furos" (publicação de matérias inéditas antes de outros veículos).

nous cherchons à diversifier les contenus, passer du sport à la politique, de la musique à l'économie toujours avec cette volonté de remplir des silos de contenus par thématiques. Pour intéresser les lecteurs nous devons les surprendre et les faire rêver. Les critères de surprise, scoop et désir sont donc prioritaires. (Stephane Arrami, entrevista em 27/07/2012)

Toda a semana eles fazem um ponto da situação, a partir dos temas já publicados e mais relevantes, estalecendo uma pauta mínima, mas nem sempre seguida, fazendo com que eles noticiem os acontecimentos em voga. Segue um padrão editorial, que Arrami traduz por uma "linha humanista e militante", voltada à "libertação espiritual e territorial" da Tamazgha (um neologismo criado pelos militantes berberes que descreve os países onde se falam a língua tamazigh berbere) e da Cabília:

La ligne de Kabyle.com est humaniste mais l'idée d'une libération spirituelle et territoriale de la Tamazgha et de la Kabylie par sa diaspora et son peuple principalement en Kabylie est prépondérante. Nous n'hésitons pas à parler de colonisation arabe en Kabylie, à souligner l'importance du devoir de mémoire aussi bien vis-à-vis de la Kabylie (1857-1871 déportations) que de la terre ancestrale berbère (palais de Koceyla)...Notre vision est bien détachée de celle des identitaires qui prônent le rejet de l'autre et promulguent un rejet de l'islam. (Stephane Arrami, entrevista em 27/07/2012)

Certamente, as questões mais controversas enfrentadas pela equipe editorial são aquelas que remetem ao conflito com os grupos islâmicos radicais e à criação de um estado autonômo berbere na Cabília. A visão deles, segundo Arrami, não é de estimular esse tipo de conflito recíproco (entre os islamistas radicais e os laicos), mas de optar por uma visão mais humanista, claramente favorável à laicidade cabila e multicultural. Durante a pesquisa observei, nessa arquitetura informativa, que a defesa de uma posição laica é compartilhada pela maioria dos internautas, mas a autonomia política da região é uma temática polêmica que se manifesta nos 
inúmeros comentários dos internautas. Obviamente, essa posição advém de uma histórica simpatia por esses valores na comunidade diaspórica cabila, mesmo que a autonomia seja um tema mais delicado que a laicidade. Contudo, ambas ocasionam momentos de tensão e violência na Cabília entre os árabes muçulmanos argelinos. Certamente, a reivindicação de uma especificidade cultural berbere e a invenção de símbolos para demarcar essa tradição comum aos povos do Magrebe, como a bandeira Amazigh, vetor de uma recriação e reestruturação de imagens do passado comum (HOBSBAWM, 1984), elementos culturais presentes entre estes povos, como a língua, provoca a atenção dos estados nacionais nos quais esses povos berberes se situam ${ }^{296}$. Suas diferenças culturais geram conflitos políticos, principalmente se essa reivindicação cultural e linguística vier acompanhada da territorial $^{297}$, a exemplo do território Azawad em Mali e da própria Cabília.

Nesse sentido, em uma entrevista ao jornalista Capucine Gabin, do site Afrik.com (em 26/06/2011), Stephane Arrami disparou: "La berberité est un sujet três sensible, qui divise les Kabyles, nous devons rester objectifs", ou seja, as questões políticas estruturam o que ele chama de "luta cultural", mas eles devem, na medida do possível, serem objetivos nessa discussão. Diferente de uma geração combatente que lutou por um nacionalismo, argelino e berbere, a própria palavra "cabila" é nova e para esse grupo pode parecer suspeita, por render à autonomia o desdobramento direto dessa reivindicação identitária. Para ele, a posição deles é humanista, militante e por um "consenso federalista na Cabília" (autonomia regional) que não entra em conflito com os cabilas, nem a parte institucional (os partidos políticos na Argélia que apoiam a identidade cultural berbere (RCD e FFS) e nem os autonomistas, nem os berberistas (partidários de um estado federal transnacional), nem os federalistas argelinos.

296 Alguns estados nacionais, como o Marrocos, veem, nos últimos anos, reconhecendo as especificidades culturais do povo Amazigh na região, para além de uma relação folclórica utilizada como atração turística pelo Estado. Em 2001 foi criado, pelo rei Mohammed VI, o Institut royal de la culture amazighe ou IRCAM, um instituto acadêmico com o objetivo de promover a cultura e a lingua amazigh nos sistemas educacionais e midiáticos do país. Obviamente, tal posição ocorreu pela enorme pressão realizada por grupos berberes da região.

297 Na Cabília, essa questão é tão controversa que não chega adquirir uma adesão maior da população envolvida. Contudo, na região de Azawad (Mali), declarada em março de 2012 território autônomo pelo movimento separatista (Mouvement National pour la Liberatión de l'Azawad MNLA), a população Touareg está completamente envolvida com a criação de um Estado Independente, que gerou conflitos não só com o governo do Mali, apoiado pela França, mas com os grupos islâmicos extremistas na região. 
6.4.2 Arquitetura informativa digital

A arquitetura informativa do site é dotada de uma grande dinamicidade. Com layout leve e predomínio do fundo branco, com frames (quadros) em azul claro, o primeiro impacto visual ao navegador-internauta é a logomarca "Kabyle.com", com o ícone da bandeira Amazigh à esquerda e "cabila" escrito abaixo, em tifinagh, o alfabeto líbio-berbere. Sua hipertextual e reticular profusão de imagens, vídeos e as notícias em tempo real atraem imediatamente aqueles que buscam se informar sobre esse universo amazigh/cabila, acessível em língua francesa, tamazigh, inglesa e espanhola. As informações publicadas possuem um espaço para comentários aberto a qualquer pessoa inscrita gratuitamente no portal. Sua arquitetura permite esse nível de interação: há comunidades de discussão, cada post tem espaço para comentários, com uma inovação: no espaço destinado aos comentários há o ícone "curtir", como o do Facebook, e aquele contrário, com o polegar para baixo, indicando "não curtir". 


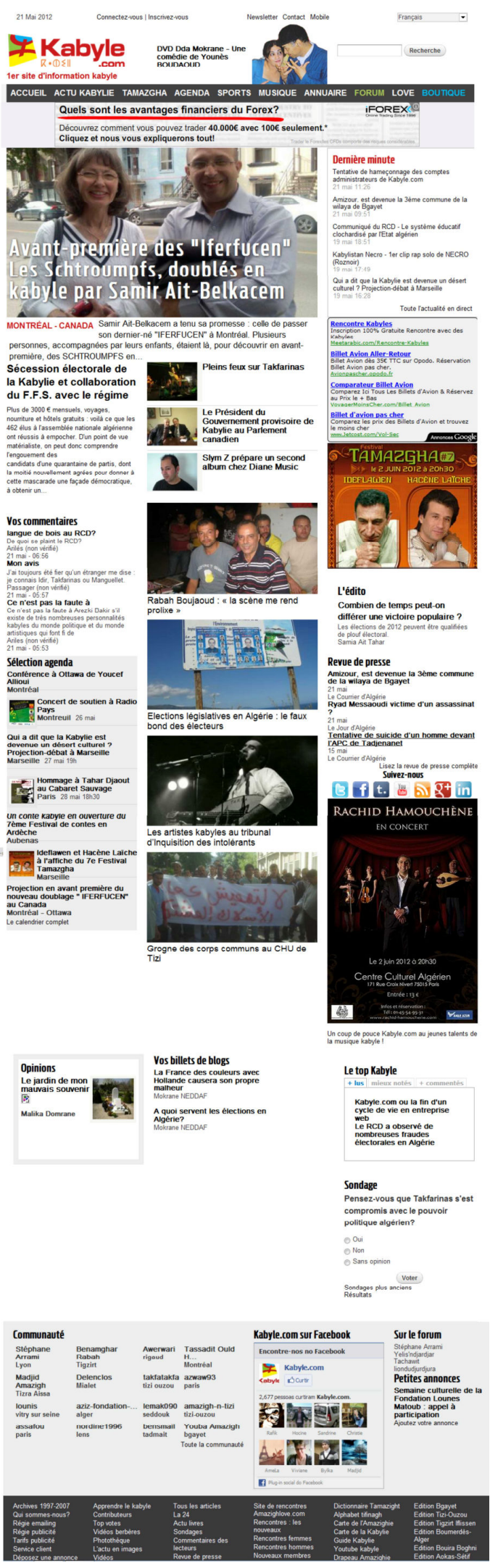

Figura 17 - Captura de tela do Portal Kabyle.com 
Na barra do menu horizontal, da esquerda para a direita, a primeira fila de links remete ao universo da cultura cabila:

"Accuiel" - página principal do Portal, com as últimas matérias publicadas. As notícias divulgadas em primeira página, como matéria principal, estão sempre acompanhadas de fotos;

"Actu Kabylie" - notícias específicas da Cabília;

"Tamazgha" - um neologismo criado pelos militantes berberes que descreve os países onde se fala a língua tamazigh (berbere). Por isso, essa secção se destina às informações sobre esses povos nesses países do Magrebe;

"Agenda" - eventos, shows, debates, manifestações, encontros a serem realizados em qualquer parte do mundo ou na Cabília. É a parte da reterritorilização cabila por excelência;

"Sports" - divulgam-se notícias esportativas, principalmente de futebol, envolvendo o club cabila Jeunesse Sportive de Kabylie, símbolo da identidade cabila, atualmente, segundo Arrami, nas mãos de dirigentes argelinos árabes;

"Musique" - matérias sobre cantores, músicas, últimas novidades e cobertura dos shows e festivais. Todos os cantores cantam em tamazigh e/ou français/árabe;

"Annuaire" - é uma espécie de diretório ou catálogo de contatos de serviços e informações úteis. Há endereço e telefone desde a proteção civil da Cabília aos serviços antiterroristas da Cabília. Uma verdadeira rede de prestação de serviços públicos e privados;

"Fórum" - É a parte mais interessante, complexa e reticular do portal, que caberia em outra tese. Boa parte das discussões está escrita em francês. Dividido nas temáticas com os "subfóruns" relacionadas entre eles:

1. Fórum Kabyle: dividido em dez fóruns com seus temas respectivos: "Salon discussions générales" (a virtualização da grande praça da vila cabila); "Parlons Kabylie" (A vida na Cabília, questões gerais sobre a vida cotidiana); "Wi-k (kem)? Nouveaux, présentez-vous" (apresentação do novos membros do Fórum)", "Soirées et manifestations kabyles" ('baladas', exposições, shows, atividades associativas, manifestações cabilas); "Fórum musique kabyle" (arquivos em mp3, traduções, partituras); "Humour" (contos e histórias divertidas presentes no imaginário cabila); "Nouveautés de la Boutique Kabyle.com" (produtos made in Cabília e mande in Tamazgha); e, finalmente, 
"Fonctionnement du Fórum e des Sites Kabyle.com" (atualização do fórum e do funcionamento das páginas do Portal).

2. Fórum Afrique do Nord: sete fóruns o compõem - "Histoire, origines e fêtes" (a história e cultura Amazigh); "Identité amazigh" (debate sobre a autonomia cabila, o racismo, a discriminação anti-amazighe, observatório da "cabilafonia"); "Contes Amazighs" (histórias narradas pelas avós e Cabília de "antigamente"); "Prénoms amazighs, généalogie" (etimologia dos nomes mais comuns adotados na tradição berbere); "Culture amazighe" (livros, filmes, rádios em amazigh); "Carnets de Voyage, photos de vacance" (conselhos de viagens, turismo solidário etc); "Fórum informatique" (discussão sobre aplicações de plataformas em tamazight).

3. Langue tamazigh: fórum da língua berbere falado pelos cabilas, chleuhs, rifains, touaregs, chenouis, chaouis, mozabites, siwis, chelhas, zayanes, zenagas, siwis. Composto por três subfóruns: "Libre expression en parlers tamazight" (voltado para as variações da língua berbere); "Linguistique, traductions, cours" (questões específicas linguísticas da língua tamazigh); "Vocabulaire et proverbes" (expressões, ditados, provérbios).

4. Kabyle.com, Le site: fórum específico para sugestões concernente ao site.

5. Os outros: "Fórum North África - Amazigh board" e "Foro Amazigh español" são voltados aos públicos falantes das respectivas línguas, inglês e espanhol. Ainda nesta parte ${ }^{298}$ são apresentados alguns dados estatísticos interessantes: o número de usuários on-line, o recorde de usuários conectados (3.614 em 21 de julho de 2011, às 13h58). No total são 21.534 assuntos com 224.214 mensagens, 2.191 membros, sendo que destes 174 são ativos ${ }^{299}$. Tal número levou Stephane Arrami, moderador e animador do Fórum, a considerar que, mesmo assim, essa forma de discussão está fadada "ao passado". As pessoas preferem participar, segundo ele, comentando as matérias postadas ${ }^{300}$.

298 Inscrevi-me no portal e pude interagir nos fóruns, nos quais eu observei silenciosamente as discussões mais atuais, como a participação das mulheres na política, a "Primavera Árabe", etc.

299 Dados de 10 de janeiro de 2013.

300 Arrami comentou que os insultos são frequentes no espaço dos comentários. Também observei as agressões verbais nos temas polêmicos. 
"Love" - bate-papo para encontros virtuais. O espaço da paquera cabila-amazigh. $\mathrm{Na}$ verdade, é um link de outra arquitetura informativa existente (site www.amazighlove.com);

"Boutique" ou "Boutique berbere" - loja on-line onde se encontram à venda CD's, livros, ingressos de shows, com espaço destinado à venda de livro ao público infantil.

No centro do portal destacam-se as informações mais atuais. No dia em que a Figura 17 foi capturada, 21 de maio de 2012, houve a divulgação, no Canadá, do filme "Os Smurfs" (Iferfucen, em berbere), dublado em tamazigh por Chatel e AitBelkacem (ambos na foto da esquerda para direita) ${ }^{301}$. Exibido para o público infantil da comunidade cabila em Montréal, o filme exemplifica como a reapropriação de narrativas globais podem significar o fortalecimento de línguas locais por meio da dublagem, mais ainda, em contextos diaspóricos.

Nesse mesmo período, houve uma grande polêmica em torno do cantor cabila mais popular da atualidade, Takfarinas ${ }^{302}$. Nas eleições municipais argelinas ele convocou seus fãs a votar. Muitos se revoltaram com sua posição e se expressaram deliberadamente no fórum do portal e nos comentários. Foi criada até uma sondagem para verificar a opinião dos internautas/usuários sobre a postura dele. A maioria da comunidade da diáspora cabila desaprova qualquer participação no sistema eleitoral argelino por reconhecê-lo como corrupto e pouco democrático. Tal reação obrigou a Takfarinas a se retratar em um vídeo reproduzido no portal.

Nesse mesmo dia, a equipe do Kabyle.com anunciou que eles sofreram um ataque hacker. As contas dos administradores do portal foram invadidas, sendo identificadas a tempo, mas não se soube a origem dessa invasão. No nível da ediáspora, a arquitetura informativa se torna o local da expressão da identidade e da

301 O Studio Double Voice é o mais importante estúdio de dublagem da língua berbere situado na Cabília. Seus trabalhos de dublagens de filmes de aventura são conhecidos em toda a diáspora cabila-berbere: "As aventuras de Narnia" [Tamagahut, 2009]; "Shrek" [Crek, 2009]; "A Era do gelo" [Pucci, 2009], entre outros, são alguns dos filmes dublados mais conhecidos. Mais informações, consultar: http://www.studiodoublevoice.com/.

302 Takfarinas, nascido em 1958 em Tixaraine, periferia de Argel. Atualmente vive em Paris e com um estilo de música cabila identificada de "Yal", uma mistura de música tradicional sob base pop. Conseguiu popularizar a música cabila na Europa. Suas letras falam tanto da opressão feminina quanto da argelina contra os cabilas. Suas músicas são a expessão máxima desse hibridismo cultural polifônico: cantadas em tamazigh, francês, árabe, com uma base ritmica glocal. 
territorialidade amazigh e cabila, amalgamada pelos seus fluxos globais, suas trocas, suas reelaborações e seus conflitos ${ }^{303}$.

$\mathrm{Na}$ barra de menu inferior estão os arquivos do site de 1997 a 2007 que estavam hospedados no site anterior ao formato atual. A apresentação da equipe e a divulgação das tarifas de publicidade são anunciadas nesse espaço. Os vídeos ${ }^{304}$, as fotos, um dicionário tamazight e mapas da Cabilía e da região que fala Amazigh no norte da África compõem esse universo tecno-imagético-linguístico berbere. As espacialidades comunicativas digitais estão rizomaticamente presentes no portal e em suas diversas interfaces (Youtube, Facebook, Google $+{ }^{305}$, Twitter), fazendo do circuito informativo digital uma "rede de redes" não somente formada pelas associações culturais, que também são polos de irradiação da diáspora cabila.

Essa diversidade de linguagens midiáticas e interfaces e a possibilidade de interação por meio do espaço para os comentários das matérias, atualizadas diariamente sobre esse mundo berbere/cabila, fazem com que o portal tenha em média 55.000 acessos por mês (sendo, deste número, 35.000 inscritos) ${ }^{306}$. Esse percentual é bastante relevante para um portal informativo independente, com uma boa reputação entre a comunidade da diáspora cabila.

Segundo Arrami, o portal vem mudando a percepção da cultura cabila no seio da sua própria comunidade ao dar visibilidade a seus acontecimentos, embora nem sempre, nessa comunidade, ocorra a unanimidade de opiniões na abordagem dos assuntos (tanto o é que os assuntos polêmicos reverberam nos comentários realizados pelos internautas). Arrami acredita que a geração de jovens cabilas, mesmo que compartilhando multipertenciamentos, precisa desconstruir os códigos de uma cultura marginal, distorcida pelos estereótipos do "beur" (nome dado aos filhos de argelinos na França) presentes e atuantes na sociedade francesa. A

${ }^{303}$ Esses conflitos inerentes às controvérsias políticas refletem também a posição do portal ao dar ampla cobertura às atividades do Governo Provisório da Cabilia, Ferhat Mehenni. Na última matéria registrada, ele, como presidente do GPK, havia realizado uma vista ao Parlamento do Canadá, estratégia diplomática para conseguir apoio nos países com comunidade cabila relevante.

${ }^{304}$ As paisagens sonoras digitais Amazigh e cabila são infinitas. Por sua amplitude e diversidade optei por não descrever um vídeo em particular. As músicas que mais me chamaram à atenção foram a "Vavá Inouva", com trechos na epígrafe do capítulo anterior, e a canção de Lounés Matoub em crítica ao Alcorão, "Allahu Akbar".

${ }^{305}$ Google+ é uma arquitera informativa digital que compartilha com sua rede de amigos todas as informações do usuário com conta Google (Youtube, Picasa, Gmail, etc.). É um exemplo de "rede de redes".

306 Através do aplicativo Google Analytics eles visualizam a localização dos acessos do site, sobretudo de fora da Cabília, confirmando sua importância para a diáspora cabila. 
mudança de perspectiva passa pelas interações com as novas tecnologias, a apropriação do "código", a difusão de vídeos, imagens, e a adoção de agências de comunicação próprias para que se faça esse tipo de ação nas redes digitais de forma profissional, autossustentável e duradoura. Para ele, tal ação comunicativa reticular é cotidiana, capaz de pluralizar cada vez mais as linguagens midiáticas a partir dos seus próprios códigos culturais (a língua tamazigh).

\subsection{TRÍADE SIMBIÔNTICA DA E-DIÁSPORA CABILA}

A e-diáspora cabila reticular e digital resplandece na emergência da ressignificação do patrimônio cultural cabila-berbere e em sua nova espacialidade "conectada" e móvel. A combinação entre cultura (perfomatização de suas identidades e memória), mídias digitais e territórios promove uma vívida reelaboração do local digital, ampliando e reinventando formas culturais relacionadas a suas comunidades. O local digital cabila da e-diáspora possui a densidade da sua trajetória histórica, traz em suas vicissitudes sua forte tradição oral (das músicas à poesia), sua conflitualidade política (principalmente com os árabes na Argélia) e sua identificação e solidariedade com os povos transnacionais Imazighen.

Numa perspectiva reticular, a "rede de redes" do Kabyle.com, como expressão da e-diáspora cabila, constitui-se pelos seus diversos planos: a rede de redatores, os circuitos das outras arquiteturas informativas digitais (Twitter, Facebook, e-mails, etc.), as redes de internautas que participam do Portal, além do território em que atravessam esses circuitos: as montanhas de Djurdjura, o mar mediterrâneo, o oceano Atlântico, entre outros ecossistemas vivos integrantes e interagentes dessa ecologia.

A presença da diáspora cabila nas redes digitais promoveu novos vínculos e novas potencialidades para suas culturas. Por exemplo, seu maior patrimônio, a sua língua, encontra reverberação em programas de ensino e difusão, dicionários, livros, contos e filmes, todos difundidos on-line nos circuitos dessa e-diáspora. Uma combinação de elementos humanos (ativistas) e não humanos (softwares e 
hardwares) que pluralizam a capacidade desses atores-redes, associativos e diaspóricos, emanando novos ecossistemas informativos.

Dito de outra forma, fazer parte dessa rede global estabelecida pelas interações com as redes digitais, que os lança para o mundo, é agregar digitalmente essas comunidades, estabelecendo novas esferas públicas discursivas diaspóricas e transnacionais (APPADURAI, 2001). Portanto, emerge um novo local das interações desses grupos com as tecnologias comunicativas, novos campos imaginativos. Um fenômeno já mencionado por Appadurai (2001) nas cinco dimensões dos fluxos disjuntivos culturais globais, nos quais as trocas dinâmicas de bens simbólicos e culturais são capazes de construir "paisagens" midiáticas (mediascape), financeiras (finanscapes), fluxos de ideias, (ideoscapes) técnicas (tecnoscape) étnicas e diaspóricas (ethnoscape) enquanto configuração global da tecnologia e das pluralidades híbridas e fluidas das identidades contemporâneas.

Tais expressões do local, igualmente paradoxais, atravessadas pelos fluxos globais comunicativos, pelos quais suas identidades e interações com as tecnologias, essenciais para a reprodução de suas especificidades culturais, estão em permanente transformação habitativa. Construído por essa ecologia comunicativa, digital e reticular, esse local digital diaspórico forma o tecido complexo (MORIN, 2001), híbrido e tradutório dessa tríade simbiôntica. Há nessas modulações digitais a emergência de novos tipos de localismos, advindos também de novas estratégias de différance:

As estratégias de différance não são capazes de inaugurar formas totalmente distintas de vida (não funcionam segundo a noção de uma "superação" dialética totalizante). Não podem conservar intactas as formas antigas e tradicionais de vida. Operam melhor dentro daquilo que Homi Bhabha denomina "tempo liminar" das minorias (Bhabha, 1997). Contudo, a différance impede que qualquer sistema se estabilize em uma totalidade inteiramente suturada. Essas estratégias surgem nos vazios e aporias, que constituem sítios potenciais de resistência, intervenção e tradução. Nesses interstícios, existe a possibilidade de um conjunto disseminado de modernidades vernáculas [...] um novo tipo de "localismo" que não é auto-suficientemente particular, mas que surge de dentro do global, sem ser simplesmente um simulacro deste (Hall, 1997). Esse "localismo" não é um mero resíduo do passado. É algo novo - a sombra que acompanha a globalização: o que é deixado de lado pelo fluxo panorâmico da globalização, mas retorna para perturbar e transtornar seus estabelecimentos culturais. É o "exterior constitutivo" da globalização (Laclau e Mouffe, 1985; Butler,1993). Encontra-se aqui o "retorno" do particular e do 
específico - do especificamente diferente - no centro da aspiração universalista panóptica da globalização ao fechamento.

O "local" não possui um caráter estável ou trans-histórico. Ele resiste ao fluxo homogeneizante do universalismo com temporalidades distintas e conjunturais. Não possui inscrição política fixa. Pode ser progressista, retrograda ou fundamentalista - aberto ou fechado - em diferentes contextos (Hall,1993). Seu impulso político não é determinado por um conteúdo essencial (geralmente caricaturado como "resistência da Tradição à modernidade"), mas por uma articulação com outras forças. Ele emerge em muitos locais, entre os quais o mais significante é a migração planejada ou não, forçosa ou denominada "livre", que trouxe as margens para o centro, o "particular" multicultural disseminado para o centro da metrópole ocidental. Somente nesse contexto se pode compreender por que aquilo que ameaça se tornar o momento de fechamento global do Ocidente - a apoteose de sua missão universalizante global - constitui ao mesmo tempo o momento do descentramento incerto, lento e prolongado do Ocidente. (HALL, 2003, p. 61-62).

As reelaborações dos vínculos sociais e das identidades culturais nas redes digitais não só as ressignificam nos contextos globais como problematizam as próprias imagens de Ocidente, perpetuadas no processo colonial. São transformações profundas, imbricadas nas interações digitais pelas quais essas experiências hibridizantes e reticulares a exemplo da cultura cabila se retraduzem nas suas interações com os dispositivos técnicos, suas "redes de redes" e suas conexões. 


\section{OS SIGNIFICADOS DO LOCAL DIGITAL DAS CULTURAS}

O processo de digitalização interessa, ao mesmo tempo, tanto às culturas locais, que passam a se reproduzir e a se transformar pelo desenvolvimento de conteúdos e de relações nas redes digitais, quanto aos seus territórios. Estes últimos, assim como as especificidades das culturas locais, não podem mais serem compreendidos de forma isolada, nem apenas na sua dimensão físico-geográfica, uma vez que, por meio dos circuitos informativos e das interfaces com os dispositivos de comunicação digital (computadores, celulares, smartphones, videocâmeras, etc.) adquirem novas dimensões.

Emerge, assim, uma localidade resultante da combinação simbiôntica entre culturas, mídias digitais e territórios que busquei analisar ao longo desta tese como expressão de um local digital das culturas, interpretada como uma forma atópica do habitar (DI FELICE, 2009), modulada pelos aparatos técnicos/digitais e pelas interfaces de um genius loci tecnológico. Na época dos antigos romanos, o genius loci representava uma espécie de "espírito do lugar" que conferia a um território sua especificidade, ressignificado na teoria da arquitetura por Christian Norberg-Schulz (1980) para designar o aspecto fenomenológico do ambiente e da sua identidade, foi restituído por Massimo Di Felice para repensar essa característica do habitar atópico e suas interfaces digitais entre os sujeitos e seus territórios.

O conceito de genius loci difundido na época romana indicava a divindade presente em um determinado lugar que protegia, custodiava e santificava o espaço, exercitando uma ação especial e ativa sobre aqueles que ali chegavam ou, mesmo temporiamente, passavam a habitá-lo [...]. As interfaces, que constituem uma nova interação entre sujeito e território, alternando continuamente o tipo e a forma de diálogo com o ambiente informativo, podem ser pensadas como um novo genius loci, tecnológico vivo. (DI FELICE, 2009, p. 247)

Esse local digital das culturas pode ser expresso como um novo genius loci tecnológico, suas interfaces digitais correspondem às novas feições das localidades 
dinâmicas e a um "fazer espaço" consorciado com os aparatos comunicativos digitais, isto é, as especificidades do local das culturas estão intrinsicamente vinculadas aos processos comunicativos reticulares e digitais, pelos quais as culturas se transformam e se reproduzem. As culturais locais em contato com as interações digitais e conectadas às redes passam a se transformar e a se reproduzir. Essa interação habitativa se desenvolve por meio da específica apropriação que cada cultura realiza com as tecnologias comunicativas e com os dinamismos resultantes da sua própria forma de interação com seu território. A fertilidade da metáfora do genis loci tecnológico nos permite, contemporanemente, pensar a especificidade e o dinamismo de cada condição habitativa.

A nossa jornada foi a de investigar o processo de digitalização de culturas locais por meio de duas experiências diferentes: uma situada no Brasil e nas redes digitais com a Rede Povos da Floresta, e a outra na e-diáspora cabila/berbere que se reúne no portal Kabyle.com. Observamos, assim, nessas experiências, expressões muito singulares do local digital das culturas presente nas redes digitais, indicadoras do advento de novas relações entre essas culturas e suas territorialidades. Vimos, a partir delas, à luz de uma perspectiva complexa e reticular situada nos meandros históricos e midiáticos digitais, a atuação de coletivos, ou atores-redes, associados a um conjunto de redes, de elementos humanos e não humanos, que transformam as formas de expressão de suas identidades e de seu modo de habitar. Ou seja, essas relações interagentes e recíprocas entre culturas locais, mídias digitais e territórios ressaltam que um processo de digitalização desses coletivos implica também no advento de transformações das formas de expressão das performances identitárias e das condições habitativas.

Apontamos, a seguir, as reflexões que podemos entrever desse estudo comparativo com relação as hipóteses propostas. 
Modelo comunicativo das redes digitais - novas interações reticulares entre culturas e territórios

O modelo comunicativo digital, conectivo e reticular, favorece novas interações comunicativas interculturais entre coletivos com referências étnicas e seus territórios. No caso da Rede Povos da Floresta, a conexão das comunidades tradicionais, após a implantação dos Pontos de Cultura Indígena, possibilitou o acesso aos equipamentos de conexão com a Internet e, assim, o registro de suas narrativas e memórias, voltadas não só para a preservação dos seus patrimônios culturais, mas também de seus territórios. Os Ashaninka do Rio Amônia, com a produção de seus vídeos e suas denúncias em seus blogs, reelaborando seu sistema de trocas tradicionais (ayonpari) de acordo com sua cosmologia comunicativa xamânica, mostraram como suas ações reticulares ajudam a defender seus territórios, apontando para um ecossistema informativo reticular interagente que reúne de forma singular o ecossistema da Floresta com o informativo-digital. Agrupa simultaneamente seus imaginários, seus pontos de vista e suas percepções ambientais com a rede xamânica (cosmológica) e as redes informativas em uma arquitetura dinâmica de "rede de redes".

De todos os modos, essa nova atuação, não dos Ashaninkas, mas também dos povos da floresta envolvidos na RPF - a partir da relação desses moradores tradicionais e do território, reelaborada com os sistemas comunicativos digitais potencializa não só as conexões entre essas comunidades, seus laços sociais, mas fomenta também a autonomia, a vigilância e o monitoriamento desses territórios. Conectadas à internet essas comunidades podem se organizar e mobilizar projetos voltados para a localidade, além de incentivar entre elas o desenvolvimento sustentável, com a promoção de iniciativas tradicionais de reflorestamento. Além disso, para eles a "conexão via satélite torna-se uma ponte e democratiza a participação das lideranças e agentes comunitários na sociedade da informação" (RPF, 2009). Isto é, permite a essas populações o acesso às informações em um contexto mais global. Vimos que essa experiência se dá, sobretudo, pela comunicação assincrônica (por e-mails) e sincrônica (por dispositíveis móveis), ao lado do registro digital de suas memórias e narrativas. As arquiteturas informativas 
digitais (site e blogs), a face observável dessa comunicação é utilizada pontualmente.

Da mesma maneira, a qualidade das interações reticulares da e-diáspora cabila analisada pela interação com o portal kabyle.com revelou-se significativa, embora mais intensa. Nessa arquitetura informativa, os conteúdos "observáveis" trocados são frequentes entre seus membros. Os fluxos informativos trocados indicam que, em situação de diáspora, as arquiteturas informativas digitais são fundamentais para a manutenção dos laços comunicativos e identitários entre os grupos. Seus territórios transcendem os atuais e originais e são, sobretudo, conectivos, móveis e digitais. Vimos que esses atores-redes estão imersos em um contexto formado de circuitos informativos, softwares, hardwares, humanos, não humanos, inseridos em espacialidades comunicativas móveis.

Ambas as ações e os agenciamentos reticulares da Rede Povos da Floresta, incluindo os Ashaninka, e da "e-diáspora" vislumbrada pelo Kabyle.com, denotam a associação de atores-redes, nos termos de Bruno Latour, sendo as primeiras em direção a uma ecologia política de coletivos (humanos e não humanos), sem a separação entre natureza e sociedade. A segunda, a e-diáspora cabila, ao estar fora do seu território original e nele encontrar-se em um conflito com as forças árabesargelinas, faz das suas arquiteturas informativas o espaço fundamental de luta de afirmação de seus valores e códigos culturais.

Este processo de digitalização condiz com aquilo que o sociólogo Manuel Castells (2003, p. 102) considerou como a sociabilidade na rede, a extensão "da vida como ela é, em todas as suas dimensões e sob todas as suas modalidades", que, sob as novas formas de interação social com a Internet, toma por base uma nova noção de comunidade na (e com a) rede ${ }^{307}$, em uma perpectiva elaborada em Barry Wellman (apud CASTELLS, 2003, p. 106), "redes de laços interpessoais que proporcionam sociabilidade, apoio, informação, um senso de integração e identidade social”. A transformação da sociabilidade, principalmente para aqueles grupos em situação de diáspora, substituiu a centralidade das comunidades espaciais pelas redes, fundamentando novas formas de sociabilidade. As redes comportam um

\footnotetext{
${ }^{307}$ Para Castells, as redes, como nós interconectados, são estruturas abertas capazes de expandir-se de forma ilimitada, integrando novos nós desde que estes consigam se comunicar dentro da rede, ou seja, compartilhem os mesmos códigos de comunicação.
} 
significado novo na sociabilidade, que passa pela influência recíproca dos atoresredes e das interfaces de comunicação.

No entanto, Castells considera que a sociedade em rede "está fundamentada na disjunção sistêmica entre o local e o global para a maioria dos indivíduos e grupos sociais" e na separação em diferentes estruturas de tempo/espaço, entre poder e experiência. As sociedades civis estariam sendo desarticuladas, pois "não há mais continuidade entre a lógica da criação de poder na rede global e a lógica de associação e representação em sociedades e culturas específicas", e, assim sendo, a "busca pelo significado ocorre no âmbito da reconstrução de identidades defensivas em torno de princípios comunais".

Derivada dessa contraposição entre o local e o global, Castells afirma que Rede e Ser (as afirmações identitárias dos sujeitos ou coletividades) se opõem. Para ele (2002a, p. 22), a sociedade em rede "está estruturada na oposição bipolar entre Rede e Ser", manifesto no poder da identidade ${ }^{308}$, ocasionando uma esquizofrenia, dado que os sistemas políticos mergulham em uma crise estrutural e os movimentos sociais passam a ser fragmentados e locais; as pessoas passam a se reunir em identidades primárias: religiosas, étnicas, territoriais, nacionais (CASTELLS, 2002b). O grande poder da identidade se expressa na tentativa de alternativas ao sistema por via de movimentos sociais articulados em torno de identidades específicas e na formação de grupos centrados em si mesmo e na autoafirmação de valores definidos como forma de proteção diante de um sistema que os exclui.

Contudo, vimos que os casos analisados, a Rede Povos da Floresta, a ecologia xamânica comunicativa Ashaninka e a e-diáspora cabila não se contrapõem

\footnotetext{
${ }^{308}$ Para Castells (2002b, p. 23-24), a identidade é "a fonte de significados e experiência de um povo", onde "significado" reporta-se à identificação simbólica, organizado em torno de uma identidade primária, que estrutura as demais. A construção social da identidade implica na principal questão, a partir de quê, por quem e para quê isso acontece, é marcada por relações de poder e distingue três formas e origens de construção de identidades: identidade legitimadora, identidade de resistência, identidade de projeto. A identidade legitimadora: derivada das instituições dominantes da sociedade com o objetivo de expandir e racionalizar sua dominação em relação aos atores sociais, se aplica às diversas teorias do nacionalismo. A identidade de resistência: criada por atores que se encontram em posições e condições desvalorizadas e/ou estigmatizadas pela lógica da dominação, construindo trincheiras de resistência e sobrevivência com base em princípios diferentes dos que permeiam as instituições da sociedade, ou mesmo opostos a estes últimos. Para Castells, essa identidade é a mais importante, já que origina formas de resistências coletivas diante da opressão e permite a formação de comunas e comunidades. Por fim, a identidade de projeto, quando os atores sociais, utilizando-se de qualquer tipo de material cultural a seu alcance, constróem uma nova identidade, capaz de redefinir sua posição na sociedade e, ao fazê-lo, de buscar a transformação de toda a estrutura social. Esse tipo de identidade produz sujeitos, aqueles que têm desejo de ser um indivíduo, de criar uma história pessoal, de atribuir significado a todo o conjunto de experiências da vida individual (CASTELLS, 2002b, p. 23-24).
} 
à rede, ao contrário, esses fluxos globais, aliados às suas especificidades culturais, fazem com que esses atores-redes retraduzam e reelaborem seus sistemas e códigos culturais em uma lógica reticular e ecossistêmica. A rede, para as experiências observadas, configura-se pela dinâmica dos processos de criação de significados:

\begin{abstract}
A rede configura-se como um conjunto de diferentes nós que interagem livre e autonomamente entre si. A partir de tais conexões espontâneas se produz muito mais que um simples repasse de informações: torna-se possível a realização de eventos inteligentes e de processos criativos de criação colaborativa de significados. Estes últimos são o resultado, não mais de um processo comunicativo planejado, e sim de um percurso autopoético que se desenvolve de maneira imprevisível, tomando forma à medida que se espalha na rede, através das conexões. (DI FELICE, 2009, p. 269)
\end{abstract}

Reforça-se, assim, por meio desse formato reticular da experiência comunitiva desses grupos, a plasticidade de suas culturas, enquanto processos de diferenciação e hibridização com as alteridades, sejam elas humanas e não humanas (MARCHESINI, 2010; LATOUR, 2012), de forma a constituir-se em uma ecologia digital conectiva (DIMINESCU, 2010; LÉVY, 1993).

Por conseguinte, (2003, p. 44) descreve como "processos que vagarosamente e sutilmente estão descentrando os modelos ocidentais, levando a uma disseminação da diferença cultural, jogo da semelhança e da diferença, processos que estão transformando a cultura no mundo inteiro". Ou seja, a digitalização que envolve as culturas e seus territórios, no interior desses processos globais, produz a proliferação da sua diferença, de seus significados posicionais, contextuais, relacionais e de seus localismos. A partir da tríade simbiôntica, as relações entre as culturais locais, as mídias digitais e seus territórios geram combinações inequívocas, glocais e dinâmicas, que repercutem na expressão proposta do local digital das culturas. 
A dimensão não instrumental das tecnologias digitais

As interações entre culturas, mídias digitais e territórios à luz dos casos analisados mostraram a fecundidade da dimensão ecologia comunicativa digital, que parte desses entrelaçamentos e combinações, aspecto este último que inviabiliza a análise limitada ao significado do uso instrumental das mídias digitais realizado por esses grupos. Certamente, nosso foco nas produções midiáticas nativas (sites, blogs, etc.) pressupõe a compreensão das apropriações dessas mídias originalmente alheias aos sistemas culturais tradicionais desses grupos (tanto dos Povos da Floresta, dos Ashaninkas e dos cabilas), mas essas interações por elas realizadas implicaram em novas formas de ação e interação no mundo social, de novos tipos de relações e vínculos entre os outros e entre eles mesmos. Este último é determinante no caso das e-diásporas, em que os vínculos comunitários são mediatizados reticular e digitalmente, ocasionando a chamada "migração conectada" ubíqua "duplamente presente" aqui e lá, ou melhor, lá e acolá (DIMINESCU, 2010), situada, portanto, no interior de uma nova ecologia digital.

Se optei por uma perspectiva reticular e pela associação dos seus elementos foi para buscar situar as tramas dessas interações em sua complexidade. Obviamente, o modo como descrevi e narrei essas interações designam um "momento", ou um acontecimento, circunstanciado por seus contextos, por seus atores-redes e pelas interfaces de suas arquiteturas informativas digitais. Na RPF vimos as associações dos seus tecno-atores por uma cronologia, em que se sobressaíram as várias conexões dessa rede heterogênea, em que os equipamentos a serem implantados não eram simplesmente objetos técnicos, mas a possibilidade de uma nova relação que proporcionaria o surgimento de um novo ecossistema somado ao da Floresta.

Assim, os dispositivos técnicos foram considerados, nesta tese, como um dos elementos da rede, constituída não apenas de humanos, mas também de não humanos (LATOUR, 2012); de entidades interagentes e tradutórias (SERRES, $\left.1993^{309}\right)$.

309 A filosofia das ciências de M. Serres, particularmente o conceito de tradução, influencia consideravelmente o trabalho de Bruno Latour, embora Serres tenha também produzido, a partir de uma filosofia da ciência - considerada como filosofia mestiça -, uma reflexão ontológica sobre 
Processo de digitalização - novas formas de expressão das identificações étnicas

A experiência midiática dessas coletividades ocasionadas pela digitalização possibilita novas formas de expressão de suas identificações étnicas e, por sua vez, reflete a transformação cultural de seus contextos locais e de suas estratégias de representação de suas diferenças. Isso indica, como já vimos, a relação não instrumental das tecnologias digitais de comunicação, dos suportes de informação e das interfaces comunicativas. Dessa forma, as interações e apropriações realizadas por esses grupos apontam para transformações significativas nos mecanismos tradicionais de performatização de suas identificações: traduzindo-se, por exemplo, no registro escrito e audiovisual (digital) de suas narrativas e memórias.

O "local digital" favorece, assim, novos protagonismos e novas dinâmicas culturais com as interações midiáticas. Situa-se no "entre-lugar" digital, um novo contexto intersticial formado por campos de performatização identitários, deslizantes, oriundos das relações e dos processos interculturais (BHABHA, 1998). Tanto as conexões quanto as produções midiáticas digitais desses grupos locais tornaram possiveis novas estratégias de diferenciação, de transformação, de subjetivação e de signos de identificações partindo de suas interações midiáticas.

É, de fato, nas arquiteturas digitais que acontece o diálogo, a reprodução e a transformação dessas culturas.

Especificamente, os Ashaninka e os cabilas, além de seus referenciais culturais, religiosos e históricos próprios, possuem línguas próprias. As interações com os dispositivos digitais, como câmeras fotográficas e audiovisuais, e a circulação e difusão nas redes digitais, viabilizam novas formas de registro de grupos originalmente orais que vivenciam a passagem não só da escritura, mas do audiovisual multiplicado pelo caráter multimidiático das redes digitais. Cada uma dessas modalidades cria novas espacialidades comunicativas que permitem a difusão do idioma e da visão de mundo desses grupos na rede. Acontecem, assim, por meio das interações com os dispositivos digitais, novas possibilidades de visibilidade, transmissão e ressignificação cultural de seus patrimônios simbólicos.

"redes". Serres considera a rede como um campo heterogêneo de tensões, formada por uma pluralidade de pontos interligados em que nenhum ponto é privilegiado em relação a outro, o que faz com que uma rede tenha múltiplas entradas, contradizendo o conceito de rede social produzido pela Sociologia. 
Os vídeos ou filmes produzidos e disseminados nas redes digitais feitos por esses grupos pluralizam as formas como também eles se veem e como os vemos ("A gente luta mas come fruta", 2006; "La colline oubliée", 1997, etc.).

Finalmente, novos e criativos processos de identificação e performatização das identidades culturais passam a existir por meio das redes digitais, apontando para modos cada vez mais híbridos, tradutórios e relacionais de suas tradições (de seus repertórios de significados). As transformações (e também as permanências) de seus códigos reintegram novas modalidades de estar no mundo, novos devires, permeado pelas ressignificações advindas de uma combinação triádica e simbiôntica entre culturas, mídias digitais e territórios, delineadas nas espacialidades comunicativas atópicas, um novo genius loci tecnológico, digital e conectivo. 


\section{REFERÊNCIAS}

ABRUZZESE, A. O Esplendor da TV: origem e destino da linguagem audiovisual. São Paulo: Studio Nobel, 2006.

ADORNO, T.W. e HORKHEIMER, M. Dialética do esclarecimento: fragmentos filosóficos. Rio de Janeiro: Jorge Zahar. 1985.

AGUIAR, S. Redes sociais e tecnologias digitais de informação e comunicação no Brasil (1996-2006). Relatório final de pesquisa. NUPEF Rits - Núcleo de Pesquisas, Estudos e Formação da Rede de Informações para o Terceiro Setor, 2006, 37 p.

ALMASUDE, A. "The New Mass Media and the Shaping of Amazigh Identity." In Reyhner, J., Cantoni, G., St. Clair, R.N. and Yazzie, E.P. (Eds.) Revitalizing Indigenous Languages. Flagstaff, Arizona: Northern Arizona University. pp. 117128. http://jan.ucc.nau.edu/ jar/RIL_10.html. Acesso: 23 de outubro de 2012.

ALMEIDA, M. B. "As colocações como forma social: sistema tecnológico e unidade de recursos naturais". Terra Indígena, ano 7, 54: 29-39, 1990.

. "Direitos à floresta e ambientalismo: seringueiros e suas lutas". In: Revista Brasileira de Ciências Sociais, vol. 19. n. 55. São Paulo, 2004, p. 3353.

ANDERSON, B. Comunidades Imaginadas. Buenos Aires: Fondo de Cultura Económica, 1993.

AQUINO, M. A., OLIVEIRA, H. P. C. Contribuições da arquitetura da informação para o website "A cor da cultura". Inf. \& Soc.: Est., João Pessoa, v.22, n.1, p. 129-143, jan./abr. 2012, p. 129-143.

AMARAL, A. "Autonetnografia e inserção online: o papel do pesquisador insider nas práticas comunicacionais das subculturas". In: Revista Fronteiras-Estudos Midiáticos, vol. 11, São Leopoldo, RS, p. 14-24, 2009.

"Etnografia e pesquisa em cibercultura: limites e insuficiências metodológicas”. In: Rev. USP [online]. 2010, n.86, pp. 122-135. Disponível em: $<$ http://www.revistasusp.sibi.usp.br/scielo.php?script=sci_arttext\&pid=S010399892010000300011\&lng=pt\&nrm=iso> Acesso: 10 de outubro de 2012.

APPADURAI, A. Modernità in polvere. Roma: Meltemi Editore, 2001.

ASSIS, M. de. O espelho. In: M. de Assis, Contos. São Paulo: Moderna, 1995, pp. 71-81.

BAIRON, Sérgio. A comunicação nas esferas, a experiência estética e a hipermídia. Rev. USP [online]. 2010, n.86 [citado 2012-12-11], pp. 16-27. Disponível em: <http://www.revistasusp.sibi.usp.br/scielo.php?script=sci_arttext\&pid=S010399892010000300003\&lng=pt\&nrm=iso>. ISSN 0103-9989. 
BARAN, P. On distributed communications: I. Introduction to distributed communications network. California: The RAND Corporation, 1964.

BARTH, F. "Grupos étnicos e suas fronteiras". In: POUTIGNAT, P. e STREIFFFENART, J. Teorias da etnicidade. São Paulo: Unesp, 1998, pp. 185-227.

BAUDRILLARD, J. Simulacros e Simulação. Lisboa: ed. Relógio D"água, 1991.

BHABHA, H. K. O local da cultura. Belo Horizonte, Editora UFMG; Brasília: Representação da UNESCO no Brasil, 1998.

BENJAMIN, W. "A obra de arte na era de sua reprodutibilidade técnica". In: Magia e Técnica, Arte e Política. São Paulo: Editora Brasiliense, 1996.

BOURDIEU, P. "O capital social: notas provisórias". In: CATANI, A. \& NOGUEIRA, M. A. (Orgs.) Escritos de Educação. Petrópolis: Vozes, 1998.

BOURDIEU, P., SAYAD, A. "A dominação colonial e o saber cultural." Revista de Sociologia e Política. 2006, n.26, Curitiba, pp. 41-60.

BOURDIEU, Pierre. "Diálogo sobre a poesia oral na Cabília: entrevista de Mouloud Mammeri a Pierre Bourdieu" In: Revista de Sociologia e Política. 2006, n.26, pp. 61-81.

BOUZIDA, D. "Worldwide Amazigh electronic forums." Amazigh Voice, vol. 3(2). Bedminster, NJ: Amazigh Cultural Association in America, 1994.

BRAGANÇA DE MIRANDA, J. A. Corpo e imagem. Lisboa: Vega, Passagens, 2008.

BRASIL. Governo Federal. Decreto n. 6.040/2007.

BRUNEAU, M. Diasporas et espaces transnationaux. Paris: Anthropos, E. Economica, 2004.

CALDAS, W. Cultura. São Paulo, Global editora. 2008.

1995.

. Luz a neon. Canção e cultura na cidade. São Paulo: Studio Nobel,

CANCLINI, Néstor García. Culturas Híbridas - estratégias para entrar e sair da modernidade. São Paulo: EDUSP, 1997.

CARDOSO DE OLIVEIRA, R. O Trabalho do Antropólogo. Brasília: Paralelo 15 Editora, 1998.

CARNEIRO DA CUNHA, M. C. e Almeida, M. B. Enciclopédia da Floresta - o Alto Juruá: práticas e conhecimentos das populações. São Paulo: Companhia das Letras, 2002.

CASTELLS, Manuel. A sociedade em rede. (A era da informação: economia, sociedade e cultura). v. 1. São Paulo: Paz e Terra, 2001a. 
O poder da identidade. (A era da informação: economia, sociedade e cultura). v. 1. São Paulo: Paz e Terra, 2001b.

. A Galáxia da internet: reflexões sobre a internet, os negócios e a sociedade. Rio de Janeiro: Jorge Zahar, 2003.

COLEMAN, J. S. "Social Capital in the creation of human Capital". American Journal of sociology. vol 94 (special supplement; S)1988, p. 95-120.

COSTA, E. Jangada digital. Rio de Janeiro: Azougueeditorial, 2011.

DE KERCKHOVE, D. A pele da cultura. São Paulo: Annablume, 2009

DE BIASI, R. Gregory Bateson: Antropologia, comunicazione, ecologia. Milão: Raffaello Cortina Editore, 2007.

DELEUZE, G. e GUATTARI, F. Mil Platôs: Capitalismo e esquizofrenia. Vol. 01, Rio de Janeiro: Ed. 34, 1995.

DEPARIS, S. R. União das Nações Indígenas (UNI): contribuição ao movimento indígena no Brasil (1980-1988). 2007. 140f. Dissertação (Mestrado em História) Departamento de História, Universidade Federal da Grande Dourados, Dourados (MT), 2007.

DI DEUS, E. Antropologia e ambiente: entre transgressões e síntese. 2007. 112f. Dissertação (Mestrado em Antropologia) - Departamento de Antropologia, Universidade de Brasília, Brasília, 2007.

DI FELICE, M. (org.). Do público para as redes - a comunicação digital e as novas formas de participação social. São Caetano do Sul: Editora Difusão, 2008a.

. Paisagens pós-urbanas: o fim da experiência urbana e as formas comunicativas do habitar. São Paulo: Annablume, 2009.

Mídias Nativas. 2008b. Disponível em:

www.grupoatopos.blogspot.com. Acesso em 30 de maio de 2010.

DI FELICE, M.; TORRES, J. C.; YANAZE, L. K. H. Redes digitais e sustentabilidade - as interações com o meio ambiente na era da informação. São Paulo: Annablume, 2012.

DI FELICE, Massimo. Redes digitais, epistemologias reticulares e a crise do antropomorfismo social. In: Revista USP, São Paulo, n. 92, p.9-19, Dezembro/Fevereiro 2011-2012.

DIMINESCU, D ; PASQUIER, D. (orgs.) Les migrants connectés, T.I.C., mobilités et migrations. In.: Réseaux, vol. 28 (159), 2010. - 273 p.

DIRECHE-SLIMANI, K. « Le mouvement des âarch en Algérie : pour une alternative démocratique autonome? ", Revue des mondes musulmans et de la Méditerranée [En ligne], 111-112 | mars 2006, mis en ligne le 08 décembre 2011, consulté le 01 février 2013. URL : http://remmm.revues.org/2873.

DURAND, G. Estruturas antropológicas do imaginário: introdução à arquetipologia geral. São Paulo: Martin Fontes, 2002. 
FAIRCLOUGH, N. Discurso e mudança social. Brasília: Editora UnB, 1992.

FERRARA, L. D. Comunicação, Espaço, Cultura. São Paulo: Annablume, 2008.

FLUSSER, V. "Do inobjeto". ARS (São Paulo) [online]. 2006, vol.4, n.8 [cited 201211-11], pp. 30-35 Available from: <http://www.scielo.br/scielo.php?script=sci_arttext\&pid=S167853202006000200003\&lng=en\&nrm=iso>. _ http://dx.doi.org/10.1590/S167853202006000200003. Acesso em 23 de outubro de 2012.

FRAGOSO, S., RECUERO, R., AMARAL, A. Métodos de pesquisa para a internet. Porto Alegre: Editora Sulina, 2011.

FRANÇA, A. "Índios somos nós". In: POVOS INDÍGENAS NO BRASIL: 2001-2005. [Editores gerais Beto Ricardo e Fany Ricardo]. São Paulo: Instituto Socioambiental, 2006, pp. 197-199.

FREIRE, L. Seguindo Latour: notas para uma antropologia simétrica. Rio de Janeiro: Vol. 11, n² 26, jan/jun. de 2006, p. 46-65.

GARCIA, J. L. "Tecnoimagem, iconografia e cultura visual - no rasto da metáfora do fogo nos media". In: García, J. L. (Eds.). Estudos sobre os Jornalistas Portugueses. Metamorfoses e Encruzilhadas no Limiar do Século XXI. Lisboa: Imprensa de Ciências Sociais, 2009, pp. 257-272.

GEERTZ, C. A interpretação das culturas. Rio de Janeiro: Zahar Editores, 1978.

GRANOVETTER, M. "The strength of weak ties". American Journal of Sociology; _vol. 78, $N^{\circ} 6$, p. 1360-1380, 1973.

GUATARRI, F. "Da produção da subjetividade" In: PARENTE, A. Imagem-máquina: A Era das Tecnologias do Virtual. São Paulo: Editora 34, 1993.

HABERMAS, J. Teoria do agir comunicativo. São Paulo: Editora WMF Martins Fontes, 2012.

HALL, S. A identidade cultural na pós-modernidade. Rio de Janeiro: Guanabara Koogan, 1998.

Da diáspora: identidades e mediações culturais, Belo Horizonte: Ed. UFMG; Brasília: Representação da Unesco no Brasil, 2003.

HARAWAY, D. A partilha do sofrimento: relações instrumentais entre animais de laboratório e sua gente. Horizonte antropológico. [online]. 2011, vol.17, n.35 [cited 2013-02-17], pp. 27-64. Available from: <http://www.scielo.br/scielo.php?script=sci_arttext\&pid=S0104$71832011000100002 \&$ Ing=en\&nrm=iso>. $\quad$ ISSN 0104-7183. http://dx.doi.org/10.1590/S0104-71832011000100002. Acesso em 21 de janeiro de 2013. 
HEIDEGGER, M. Ensaios e conferências. Petrópoles-RJ: Vozes, 2006.

. Ensaios e Conferências. $7^{a}$ edição. Petrópolis: Vozes; Bragança

Paulista: Editora Universitária São Francisco, 2006.

HINE, C. Virtual Ethnography. London, Sage, 2000.

HODKINSON, P. "Insider research" in the study of youth cultures. Journal of Youth Studies, 18: pp. 121-149, p. 2005.

LACOSTE-DUJARDIN, C. Dictionaire de la culture berbère em Kabylie. Paris: La Découverte, 2005.

LATOUR, B. Ciência em ação: como seguir cientistas e engenheiros sociedade afora. São Paulo: Editora Unesp, 2000.

$\overline{\text { Edusc, } 2004 .}$

Políticas da Natureza: como fazer ciência na democracia. Bauru,

Reagregando o social: uma introdução à teoria do Ator-Rede. Salvador: Edufba, 2012; Bauru-SP: Edusc, 2012.

LASSWEL, H. "The structure and function of communication in society" In: BRYSON, $L$ (org.). The communication of ideas. New York: Haper, 1948.

LEMOS, A. Cibercultura. Tecnologia e vida social na cultura contemporânea. Porto Alegre, Ed. Sulina, 4ª Ed, 2002.

LESSIN, L. Nos rastros de yakuruna: a partida de Pawa e a pós- sustentabilidade Ashaninka. 2011. 204f. Tese (Doutorado em Antropologia) - Departamento em Antropologia, Universidade Estadual de São Paulo, Marília, 2011.

Disponível em: http://www.marilia.unesp.br/Home/PosGraduacao/CienciasSociais/Dissertacoes/lessin_I_do_mar.pdf

LÉVY, Pierre. As tecnologias da inteligência. O futuro do pensamento na Era da Informática. São Paulo: Editora 34, 1993. . O que é o virtual. São Paulo: Editora 34, 1996. . Cibercultura. São Paulo: Editora 34, 1999.

LÉVÊQUE, C. Ecologia - Do ecossistema à biosfera. Lisboa: Instituto Piaget, p. 2001.

LIMA-MARQUES, M.; MACEDO, F. L. O. Arquitetura da informação: base para a gestão do conhecimento. In: TARAPANOFF, K. O. (Ed.). Inteligência, informação e conhecimento. Brasília: IBICT, 2006. p. 241-255.

LIN, N. "Building a Theory of Social Capital", Connections, 22(1), 1999. 28-51. Disponível em: http://www.insna.org/Connections-Web/Volume22-1/V22(1)-2851.pdf. Acesso em: jul. 2011.

KOZINETS, R. V. Netnography: Doing Ethnographic Research Online. London, Sage, 2010. 
KIM, J. H. Cibernética, ciborgues e ciberespaço: notas sobre as origens da cibernética e sua reinvenção cultura. In: Horizontes Antropológicos. Porto Alegre, ano 10, n. 21, pp. 199-219, jan/jun. 2004.

MACHADO, I. "Sensus communis: para entender o espaço acústico em seu ambiente sensorial". E-Compós (Brasília), v. 14, p. 1-17, 2011

MAFFESOLI, M. No fundo das aparências. Petrópolis-RJ: Vozes, 1996. Sobre o nomadismo. Rio de Janeiro: Record, 2001.

MAIGRET, Éric. Sociologia da comunicação e das mídias. São Paulo: Senac, 2010.

MARCHESI, M. T. A roda em rede: a capoeira em ambientes digitais. 2012. 260f. Dissertação (Mestrado em Ciências da Comunicação) - Escola de Comunicações e Artes, Universidade de São, São Paulo, 2012.

MARCHESINI. R. "Capítulo 5 - Contra a pureza essencialista, rumo a novos modelos de existência". In: DI FELICE, M; PIREDDU, M. Pós-Humanismo: as relações entre o humano e a técnica na época das redes. São Caetano do Sul: Difusão Editora, 2010, pp. 163-183.

MARCONDES FILHO, C. (org.) Dicionário da comunicação. São Paulo: Paulus, 2009.

MARTIN-BARBERO, J. Dos meios às mediações: comunicação, cultura e hegemonia, Rio de Janeiro: Editora UFRJ, 2001.

MARTINS, H. "Aceleração, progresso e experimentum humanum". In: Martins, H. \& García, J. L. (Ed.). Dilemas da civilização tecnológica. Lisboa: Imprensa de Ciências Sociais, 2003, pp. 19-77.

MASCHERONI, G. PASQUALI, F. Breve dizionario dei nuovi media. Torino: Carocci Editore, 2006.

MATTELART, A. e M. História das teorias da comunicação. São Paulo: Edições Loyola, 2003.

MATURANA, H. e VARELA, F. De máquinas e seres vivos. Autopoiese, a Organização do Vivo. Porto Alegre: Artes Médicas, 1997.

McCORMICK, J. Rumo ao paraíso. A história do movimento ambientalista, Rio de Janeiro : Relumé-Dumara, 1992.

MCLUHAN, M. Os meios de comunicação como extensões do homem. Rio de janeiro, Cultrix, 1969. 
MENDES, M. K. Etnografia preliminar dos Ashaninka da Amazônia brasileira. 1991. 160f. Dissertação. (Mestrado em Antropologia) - Departamento de Antropologia, Universidade de Campinas, Campinas, 1991.

In: "Habitantes: os Ashaninka". In: CARNEIRO DA CUNHA, M. C. e

Almeida, M. B. Enciclopédia da Floresta - o Alto Juruá: práticas e conhecimentos das populações. São Paulo: Companhia das Letras, 2002.

MEYROWITZ, J. Oltre il senso del luogo: como i media elettronici influenzano il comportamento sociale. Bologna: Baskerville, 1995.

MONTERO, P. "Cultura e comunicação: a tradução cultural e a re-invenção da etnicidade". In: DOWBOR, L.; IANNI, O; RESENDE, P-E; SILVA, H. Desafios da comunicação. Petrópolis: Editora Vozes, 2003, pp. 146-154.

MORIN, E. Introdução ao pensamento complexo. Porto Alegre: Editora Sulina, 2011.

. Il método - la natura della natura. Milão: Raffaello Cortina Editore, 2001.

EL MOUNTASSIR, A. "Les Médias et la Déformation du Nom Propre Berbère." In MOSELEY, C., OSTLER, N., OUZZATE, H. (Eds.) Endangered Languages and the Media, Proceedings of the Fifth FEL Conference, 20-23 September 2001, Agadir, MOROCCO. B. Foundation for Endangered Languages. pp. 120-123.

NEVES, M. de S. "História, memória e memorialística". In: Esboços (UFSC), Florianópolis, v. 5, n.11, p. 11-24, 2004.

NORA, P. "Entre memória e história: a problemática dos lugares". In: Projeto História. São Paulo, nº 10, p. 7-28, dez. 1993.

OLASAGASTI, M. "Esencia de la Tecnica". In: Introducción a Heidegger. Madrid: Ediciones de la Revista de Occidente, 1967, pp. 118-139.

OLIVEIRA, H. P. C.; AQUINO, M. de A. "Contribuições da Arquitetura da Informação para o website "a cor da cultura"'. Informação e Sociedade: Estudos, João Pessoa, v.22, n.1, p. 129-143, jan./abr. 2012.

PAPIANI, A. Programa de Índio: criando uma ponte sonora entre as culturas. Revista Novos Olhares. São Paulo, Vol.1 N.1., 107-118, 2012.

PARRA, H. Z. M. "Conhecimento e tecnologias visuais: dimensão sócio-técnica, linguagem e limites do humano". Intexto, Porto Alegre, UFRGS, n.26, p. 64-80, jul. 2012.

PEREIRA, E.S. Ciborgues indígen@s.br: a presença nativa no ciberespaço. 2007. 167f. Dissertação (Mestrado em Ciências Sociais - Estudos Comparados) - Centro de Pesquisa e Pós-Graduação sobre as Américas, Universidade de Brasília, 2007.

"Nos meandros da presença étnica indígena na rede digital", In: DI FELICE, M. (org) Do público para as redes - a comunicação digital e a novas formas de participação social. São Caetano do Sul: Editora Difusão, 2008, pp. 287333. 
"Mídias nativas digitais e netativismo ecossistêmico - o caso da Rede Povos da Floresta". IV Simpósio Nacional de Pesquisadores em Cibercultura. Rio de Janeiro, 18 a 21 de novembro de 2010, [comunicação] na mesa do eixo temático: "4. Biopolítica, Vigilância e Ciberativismo". Texto disponível no site do evento: moodle.stoa.usp.br/mod/resource/view.php?id=31227

Mídias Nativas: a comunicação audiovisual indígena - o caso do projeto Vídeo nas Aldeias. Ciberlegenda. Niterói: PPGCOM-Universidade Federal Fluminense, Vol. 1, No 23, pp. 61-72, 2010.

Ciborgues indígen@s.br: a presença nativa no ciberespaço. São

Paulo: Annablume, 2012.

PIMENTA, José. Índio não é todo igual: a construção Ashaninka da história e da política interétnica. 2002. 320f. Tese (Doutoramento em Antropologia) Departamento de Antropologia, Universidade de Brasília, Brasília, 2002.

Desenvolvimento sustentável e povos indígenas: os paradoxos de um exemplo amazônico. In: Anuário Antropológico, 2002-2003: p. 115-150, 2004. Indigenismo e ambientalismo na Amazônia ocidental: a propósito dos Ashaninka do rio Amônia. In: Revista de Antropologia. v.50 n.2 São Paulo dez. 2007.

POUTIGNAT, P. e STREIFF-FENART, J. Teorias da etnicidade. São Paulo: Unesp, 1998.

PLANTADE, Y. « Laïcité et athéisme en kabylie: mythes et ambigüités ». Journal d'étude des relations internationales au Moyen-Orient, Vol. 2, No.1 (janvier 2007), pp. 81-94

PUTNAN, R. Comunidade e democracia a experiência da Itália moderna. Rio de Janeiro: FGV, 1996.

RECUERO, R. Redes sociais na Internet. Porto Alegre: Sulina, 2009.

REIS, C. e LOPES, A. C. M. Dicionário de teoria da narrativa. São Paulo: Editora Ática, 1988.

RICOUER, P. A memória, a história, o esquecimento. Ed. Unicamp, 2008.

RIFIOTIS, T. "Antropologia do ciberespaço: questões teórico-metodológicas sobre a pesquisa de campo e modelos de sociabilidade". In: RIFIOTIS, T, MAXIMO, M. E., LACERDA, J. S., SEGATA, J. Antropologia do ciberespaço. Florianópolis: Editora da UFSC, 2010, p. 15-27.

RYAN Jenny (2008) The virtual campfire: an ethnography of online social networking. [online]. Last accessed [date] at: http://www.thevirtualcampfire.org/thevirtualcampfire.pdf. Acesso em 23 de julho de 2011.

ROBERTSON, R. Globalization: Social Theory and Global Culture. Sage Publications, London, 1992. 
ROCHA, L. M; MONTARDO, S. P. "Netnografia: incursões metodológicas na cibercultura". In: E-Compós. Revista da Associação Nacional dos Programas de Pós-Graduação em Comunicação. Disponível em: http://www.compos.org.br/seer/index.php/e-compos/article/viewFile/55/55. Acesso em: 16 de novembro de 2012.

ROSENFELD, L.; MORVILLE, P. Information Architecture for the Word Wide Web. 3. ed. Sebastopol, CA: O'Reilly, 2006.

SA, S. "Netnografias nas Redes Digitais", in J. L. Prado. Crítica das Práticas Midiáticas. São Paulo, Hacker, 2002.

SAHLINS, M. La découverte du vrai sauvage, et autres essais. NRF Gallimard, 2007.

SANTAELLA, L. Culturas e artes do pós-humano: da cultura das mídias à cibercultura. São Paulo: Paulus, 2003.

Paulo: Paulus, 2004.

Navegar no ciberespaço: o perfil cognitivo do leitor imersivo. São

"Pós-humano, pós-humanismo e anti-humanismo: discriminações".

In: DI FELICE, M; PIREDDU, M. Pós-Humanismo: as relações entre o humano e a técnica na época das redes. São Caetano do Sul: Difusão Editora, 2010, pp. 99-144.

SANTOS, M. Metamorfoses do espaço habitado. São Paulo: Hucitec, 1988.

SANTOS, L. G. "Tecnologia, natureza e a redescoberta do Brasil". In: Tecnociência e Cultura. São Paulo: Estação Liberdade, 1998, pp.38-43.

SARTORI, G. Comparación y método comparativo. In: Satori, G e Morlino, L. La comparación en las ciencias sociales. Madrid: Alianza Editorial, 1994.

SAVAZONI, Rodrigo e COHN, Sergio. Cultura digital.br. Rio de Janeiro: Azougueeditorial, 2009.

SCHOLES, Robert e KELLOG, Robert. O legado oral na narrativa escrita. A natureza da narrativa. Recife: Macgraw- Hill do Brasil, 1977.

SCOTT, J. Social network analysis. UK: Sage Publications, 2000.

SEGATO, R; L.. "Em busca de um léxico para teorizar a experiência territorial contemporânea". História Revista (UFG), Brasília - DF, v. 10, n.2, 2005, p. 195-226.

SERRES, M. Filosofia mestiça.Rio de Janeiro:Nova Fronteira,1993.

Unimarco, 1999.

Luzes: cinco entrevistas com Bruno Latour. São Paulo: Editora

SIMONDON. G. L'individuation psychique et collective. Paris: Aubier, 1989.

SLOTERDIKJ, P. Esferas III. Espumas. Madrid: Ediciones Siruela, 2009. 
SOARES, R. L. Margens da comunicação: discurso e mídias. 2001. 210f. Tese (Doutorado em Ciências da Comunicação) - Escola de Comunicações e Artes da Universidade de São Paulo, São Paulo. 2001.

SODRÉ, Muniz. Antropológica do espelho. Uma teoria da comunicação linear e em rede. Petrópolis-RJ: Vozes, 2008.

SOFIANE, Y. e JAABOUK, M. "Dossier. Si tamazgha m'était contée”. In: Le courrier de I'Atlas. L'actualité du Maghreb em Europe. n. 61, juillet/août 2012, Paris, pp. 5579.

STANGL, A. e-tno: a etnicidade digital. 2004. 130f. Dissertação (Mestrado em Comunicação) - Faculdade de Comunicação, Universidade de Federal da Bahia, Salvador, 2004.

STENGERS, I. The cosmopolitical proposal. In: LATOUR, B.; WEIBEL, P. (Org.). Making things public: atmospheres of democracy. Cambridge: MIT Press, 2005. p. 994-1003.

THIRY- CHERQUES, H. R. "Pierre Bourdieu: a teoria na prática". Revista de Administração Pública, n. 40, p. 27-56, 2006.

VATTIMO, G. A sociedade transparente. Lisboa: Edições 70, 1989.

VENTURINI, T. "Piccola introduzione alla cartografia delle controversie". In: Etnografia e ricerca qualitativa, vol. 3, 2008. Acesso em 23 de julho de 2011. Disponível:

<http://www.tommasoventurini.it/web/uploads/tommaso_venturini/Introduzione_Carto grafia_Controversie.pdf>

VETTORAZZO FILHO, H. "O espelho", no mito de Narciso, em Machado de Assis e em Guimarães Rosa: the narcissism thought as condition of ego's structuring. Ide (São Paulo) [online]. 2007, vol.30, n.45 [citado 2012-11-10], pp. 130-137. Disponível em: $\quad<$ http://pepsic.bvsalud.org/scielo.php?script=sci_arttext\&pid=S0101$31062007000200017 \&$ lng=pt\&nrm=iso $>$.

VERDUM, R. Consideração sobre o orçamento indigenista federal. 07 de julho de 2011. Site do INESC. Disponível in:

http://www.inesc.org.br/biblioteca/publicacoes/artigos/consideracao-sobre-oorcamento-indigenista-federal. Acesso em 12 de janeiro de 2013.

VIVEIROS DE CASTRO, E. Os pronomes cosmológicos e o perspectivismo ameríndio. In: Mana vol.2 no.2 Rio de Janeiro Oct. 1996.

THIRY-CHERQUES, H. R. RAP. Rio de Janeiro 40(1):27-55, Jan./Fev. 2006

WELLMAN, B. The three ages of internet studies: tem, five and zero years ago. London, Vol. 6 Issue I, p. 123-129, 2004. 


\section{Documentos Sonoros}

PIANKO, Francisco, Benki etc. Homãpari Ashaninka. Acre, 2005, 1CD (55 min.).

Disponível online: http://cliquemusic.uol.com.br/discos/ver/homapani

\section{DVD}

VÍDEO NAS ALDEIAS. Cineastas Ashaninka, 2007.

\section{Websites}

Blog do Centro Yorenka Ãtame, Saberes da Floresta:

http://saberesdafloresta.blogspot.com.br/

Blog da pesquisa:

http://localdigitaldasculturas.wordpress.com

Floresta Digital:

http://www.florestadigital.acre.gov.br

Rede Kabyle:

www.kabyle.com

Redes Povos da Floresta:

http://www.redepovosdafloresta.org.br/

Portal Kabyle

http://www.Kabyle.com

e-Diaspora Atlas:

www.e-diasporas.fr/

Site de biografia e personalidades Berberes

http://tameddurt.com/

Ensino de língua berbere

http://www.tinmel.net/kabylefacile/

Livros e revistas Berberes

http://idlisen.com/

Associação cultural Imedyazen na Argélia

http://imedyazen.com/

Associação Apulee

http://apulee.com/

Ensino da língua berbere em Glèbe Collegiate Institute, Ottawa http://www.taqbaylit.com/ 
Studio Double Voice

http://studiodoublevoice.com

Revista literária berbere

http://ayamun.com/

Literatura berbere

http://imyura.net/

Blog do escritor Malek Houd

http://aghucaf.wordpress.com

Asssociação Tamazgha (Paris)

http://tamazgha.fr/

\section{Vídeos - Youtube}

A gente luta mas come fruta (Bebito Piãko e Isaac Piãko, Vídeo nas Aldeias, 2006)

Parte 1

http://www.youtube.com/watch?feature=player_embedded\&v=mobDdqvht5s

Parte 2

http://www.youtube.com/watch?feature=player_embedded\&v=fL18mVzRfHQ

Parte 3

http://www.youtube.com/watch?feature=player_embedded\&v=RmeFpj1e_b0

Parte 4

http://www.youtube.com/watch?feature=player_embedded\&v=3mPPdbzg9B0

Parte 5

http://www.redepovosdafloresta.org.br/exibeVideosOEscolhido01.aspx?video=17

Centro Yorenka Atame (Stefania Fernandes, 2008)

http://www.youtube.com/watch?feature=player_embedded\&v=HOaA2-SFxYY

Primeira Roda de Conversa (RPF, 2009)

http://www.youtube.com/watch?feature=player_embedded\&v=9un2RiCcasw

Canção de Idir - A Vavá Inouva (1992)

http://www.youtube.com/watch?v=DHaFzkgk_Bs

Canção de Lounes Matoub - Allah Akbar

http://www.youtube.com/watch?v=Y64MFvEbGkg

Vídeos - Dailymotion 
La colline oubliée (Abderrahmane Bouguermouh, 1997)

Parte1

http://www.dailymotion.com/video/x6e19v_1-la-colline-oubliee_shortfilms

Parte 2

http://www.dailymotion.com/video/x6en66_2-la-colline-oubliee_shortfilms

Parte 3

http://www.dailymotion.com/video/x6fdo2_3-colline-oubliee_shortfilms

Parte 4

http://www.dailymotion.com/video/x6fdue_4-colline-oubliee_shortfilms\#.USE3Tvluf74

Parte 5

http://www.dailymotion.com/video/x6gpof_5-la-colline-oubliee_shortfilms\#.USE3dPluf74

Esta tese possui uma extensão digital. Registros audiovisuais e fotográficos realizados durante a investigação estão disponíveis no blog da pesquisa "O local digital das culturas".

http://localdigitaldasculturas.wordpress.com

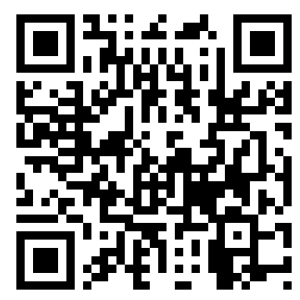




\section{APÊNDICE}

Apêndice 1 - Vista aérea do rio Juruá

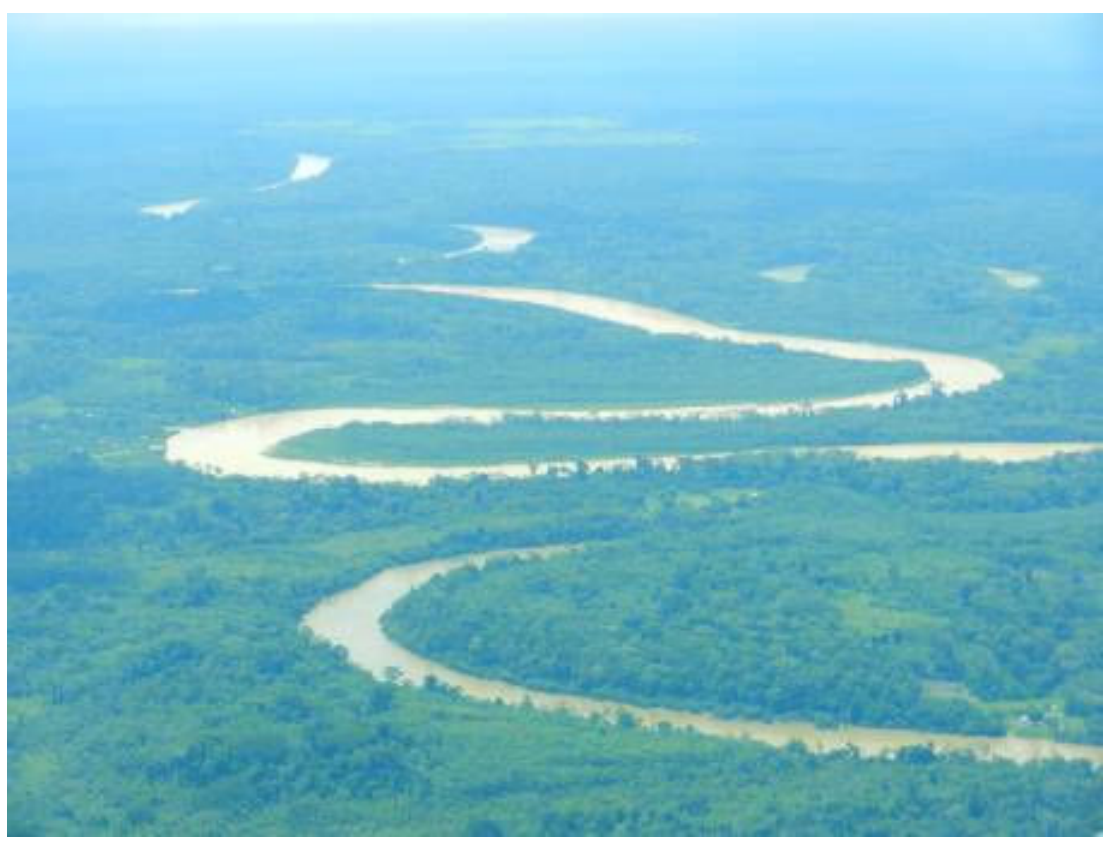

Apêndice 2 - Marechal Thaumaturgo (AC) - Centro Yorenka Ãtame ao fundo

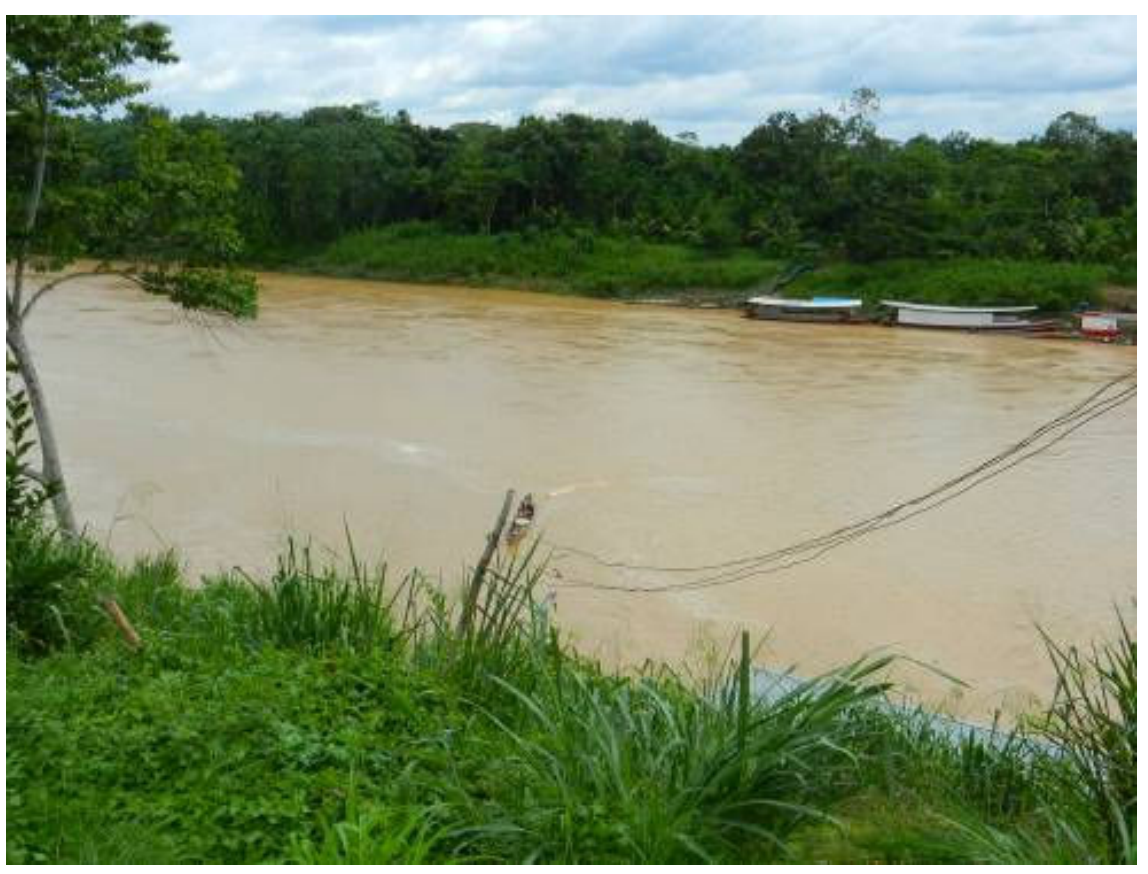


Apêndice 3 - Marechal Thaumaturgo (AC) - Centro Yorenka Ãtame Sala de informática

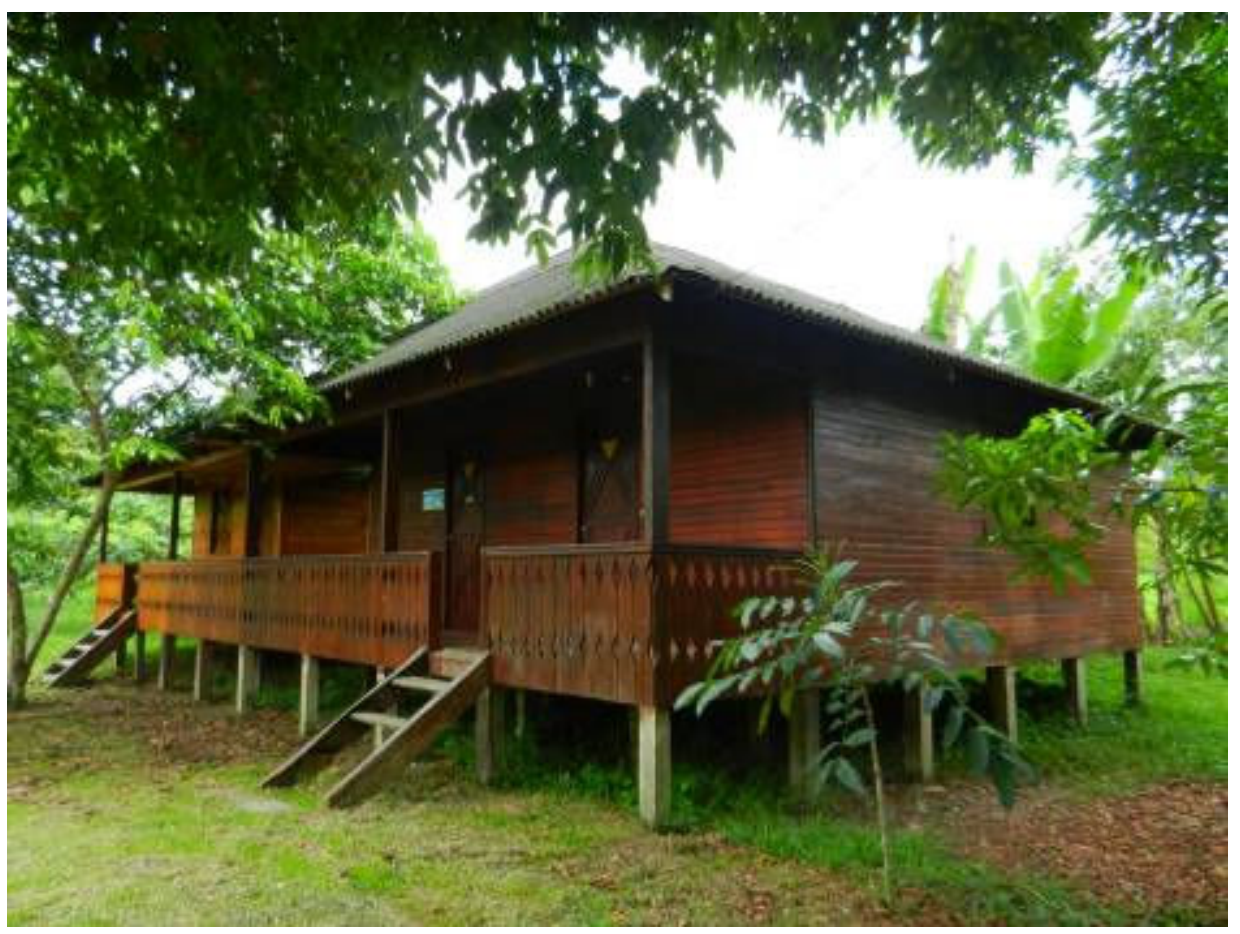

Apêndice 4 - Marechal Thaumaturgo (AC) - Centro Yorenka Ãtame Detalhe da porta da sala de informática

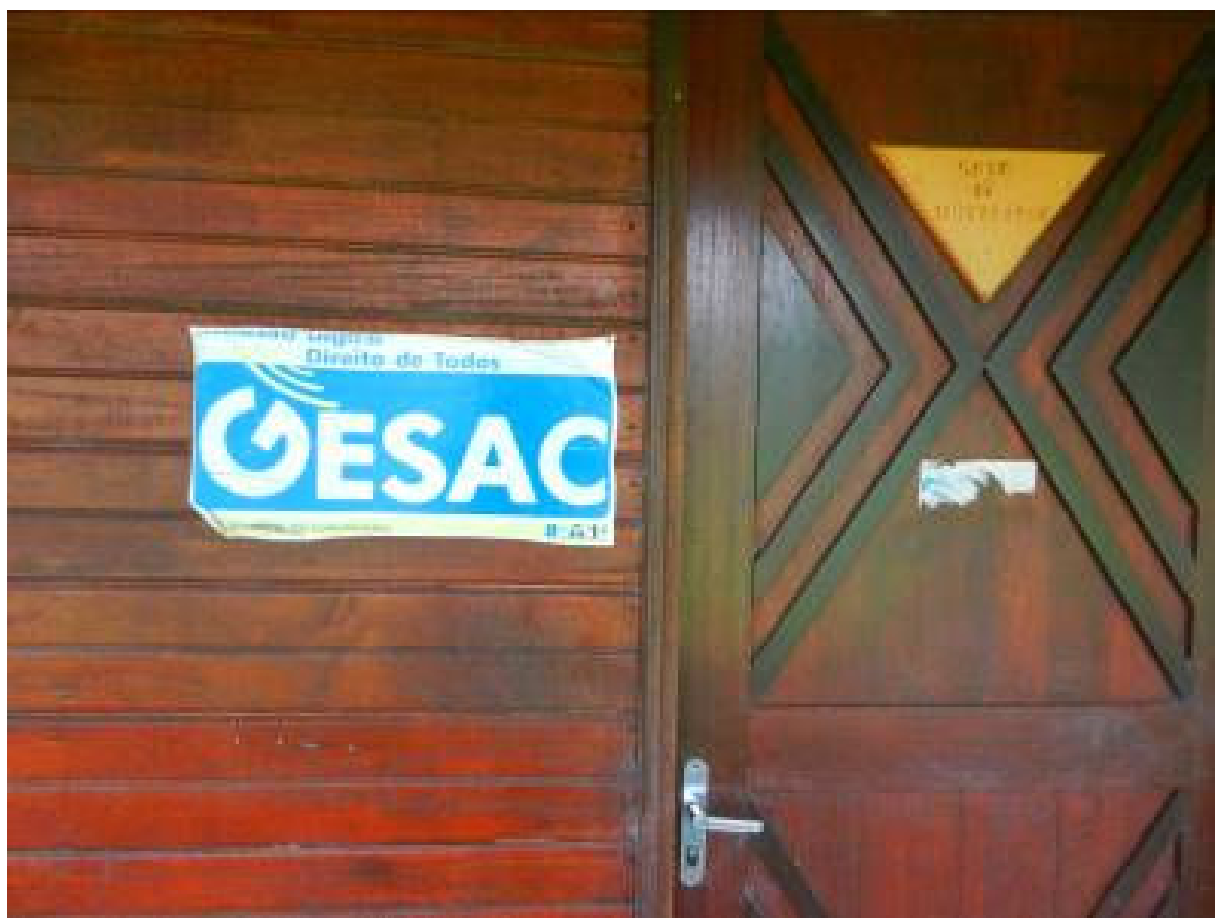


Apêndice 5 - Centro Yorenka Ãtame - Marechal Thaumaturgo (AC) - Escritório - Célia, esposa de Benki Pianko

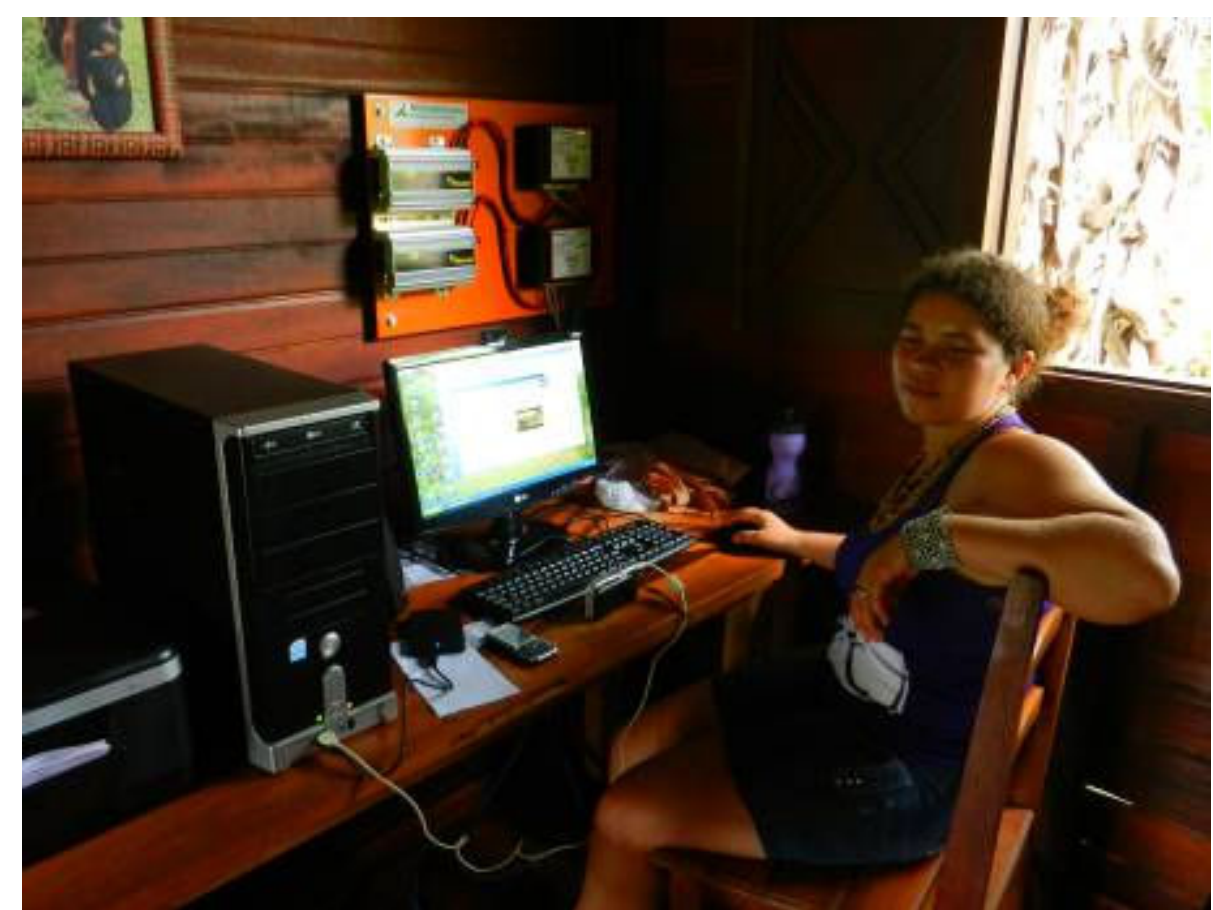

Apêndice 6 - Centro Yorenka Ãtame - Marechal Thaumaturgo (AC) - Escritório Jovem do município

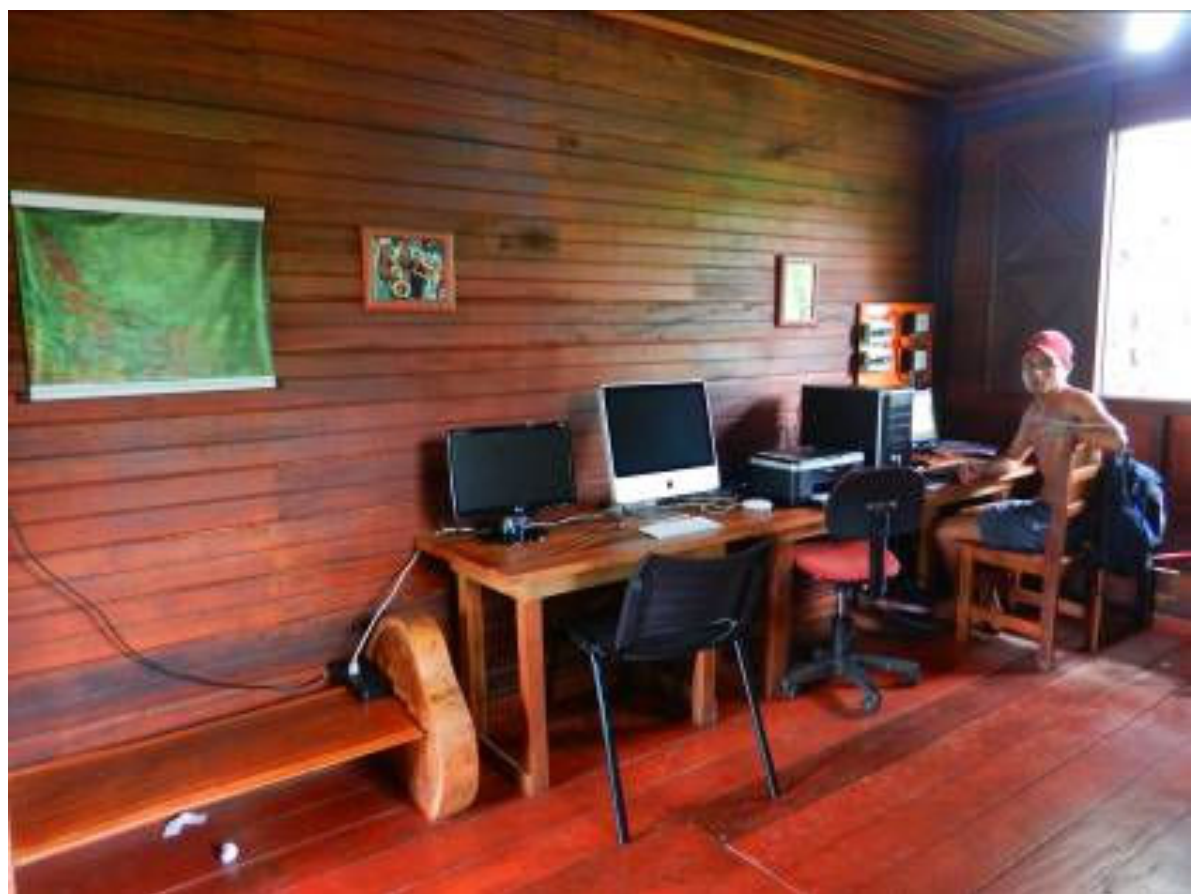


Apêndice 7 - Centro Yorenka Ãtame - Marechal Thaumaturgo (AC) - Entrevista com Benki Pianko (01/12/12)

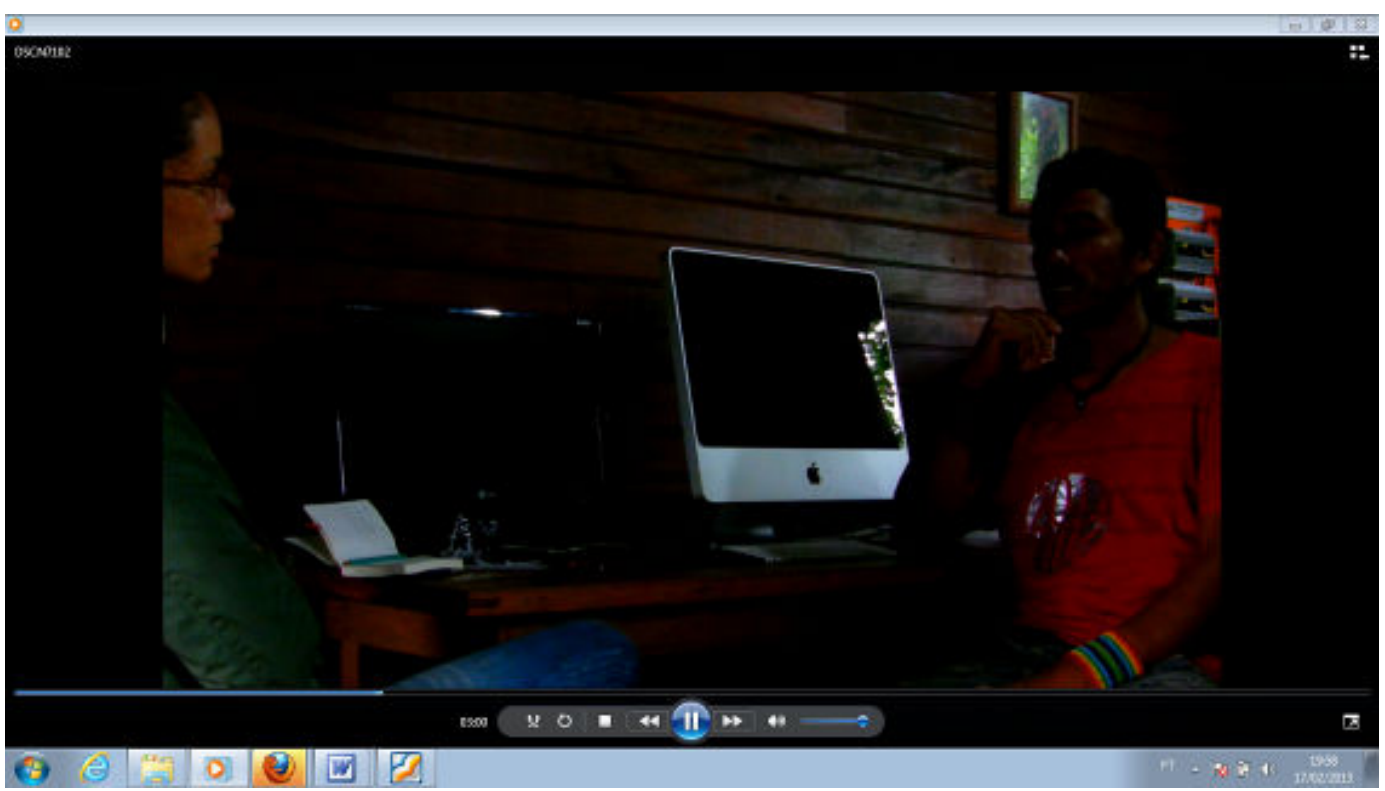

Apêndice 8 - Aldeia Apiwtxa - Espaço com computadores com acesso à Internet (à esquerda); Sede da Cooperativa Ayonpare (à direita).

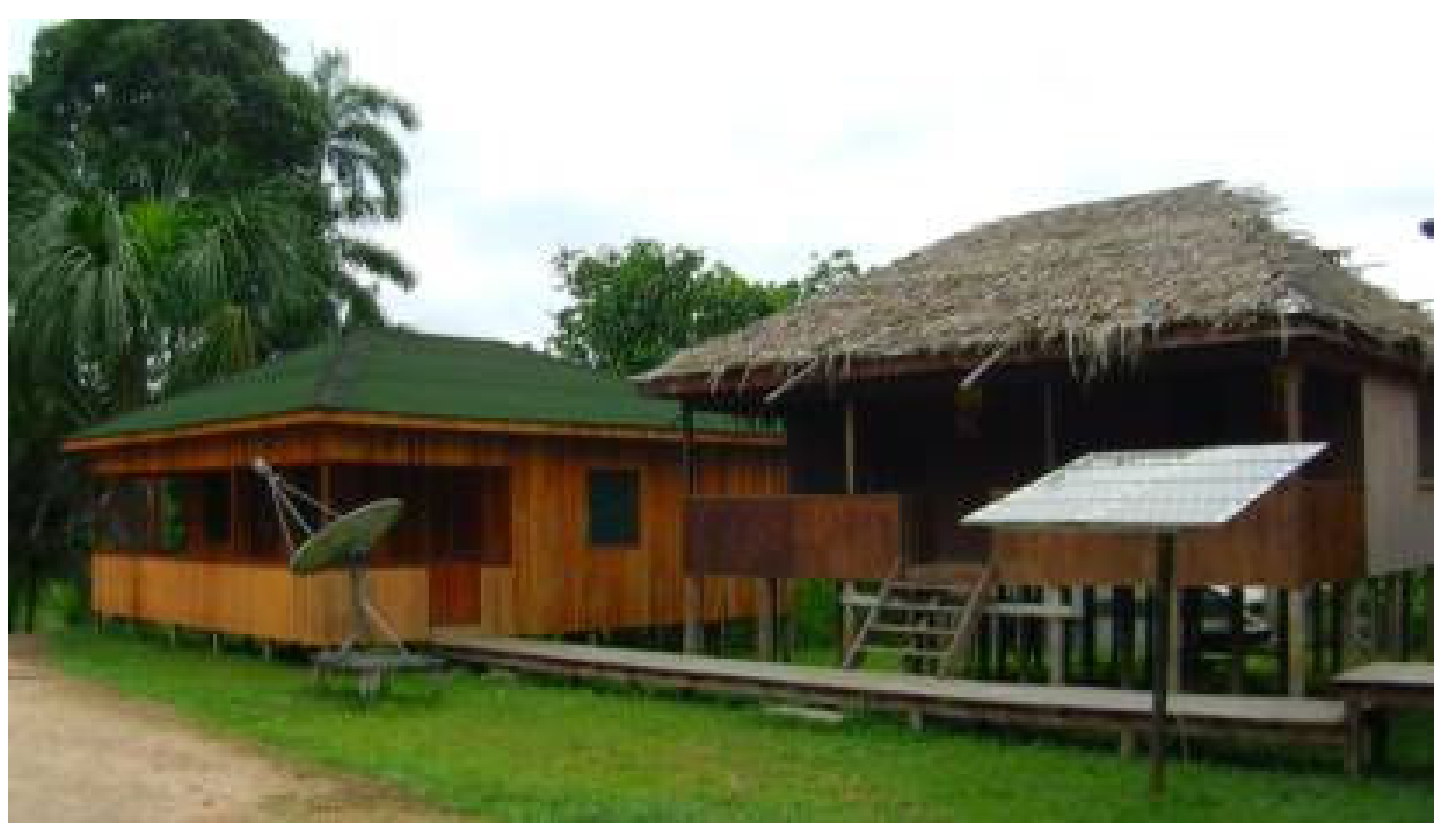


Apêndice 9 - Aldeia Apiwtxa - Espaço com computadores com acesso à Internet

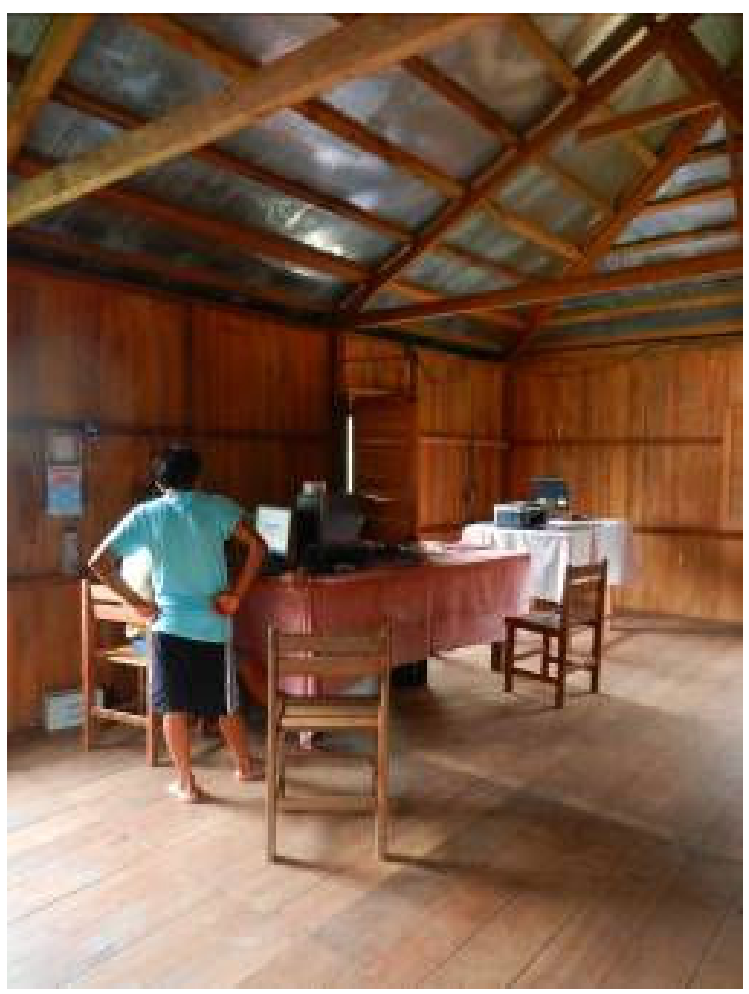

Apêndice 10 - Aldeia Apiwtxa - Casa da Família Pianko

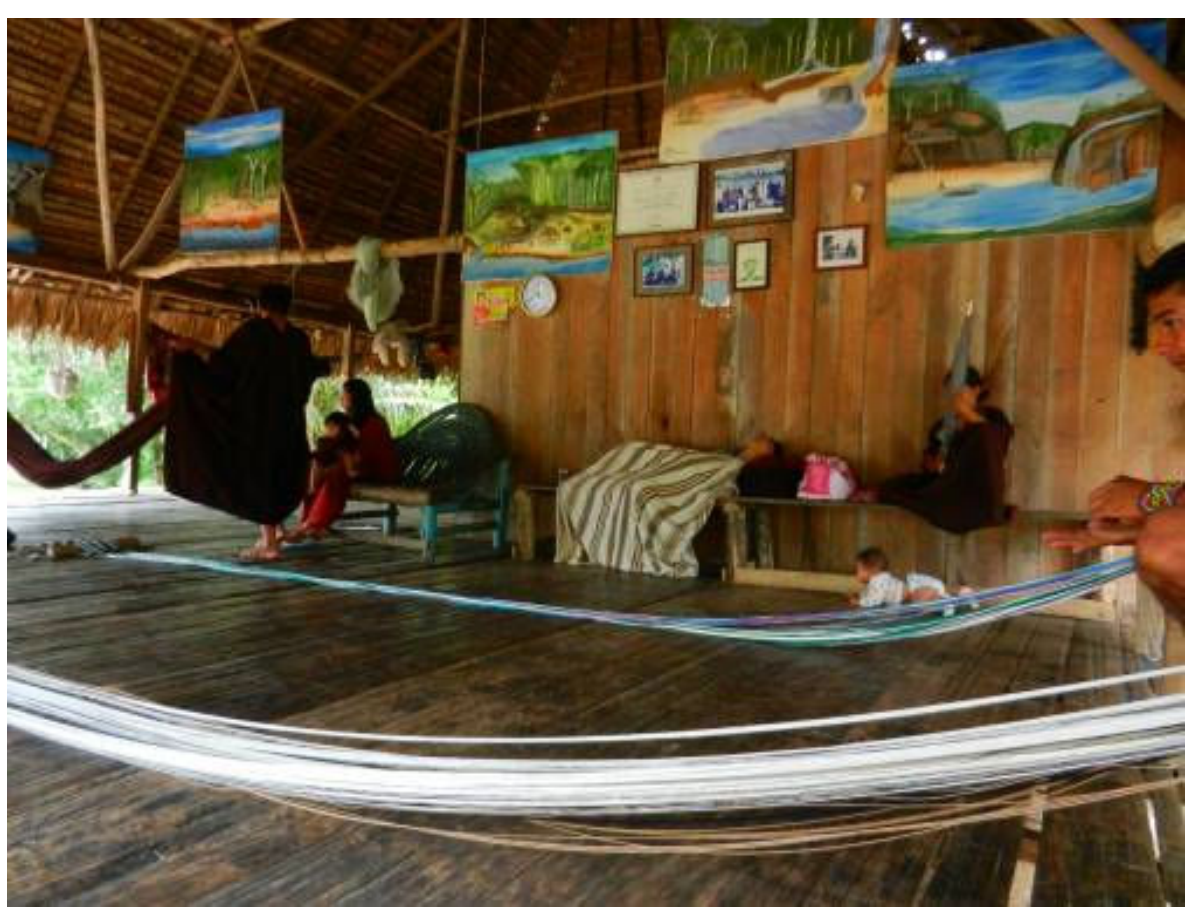


Apêndice 11 - manifestação em defesa do território Azawad (Mali) em Paris, 07/07/2012

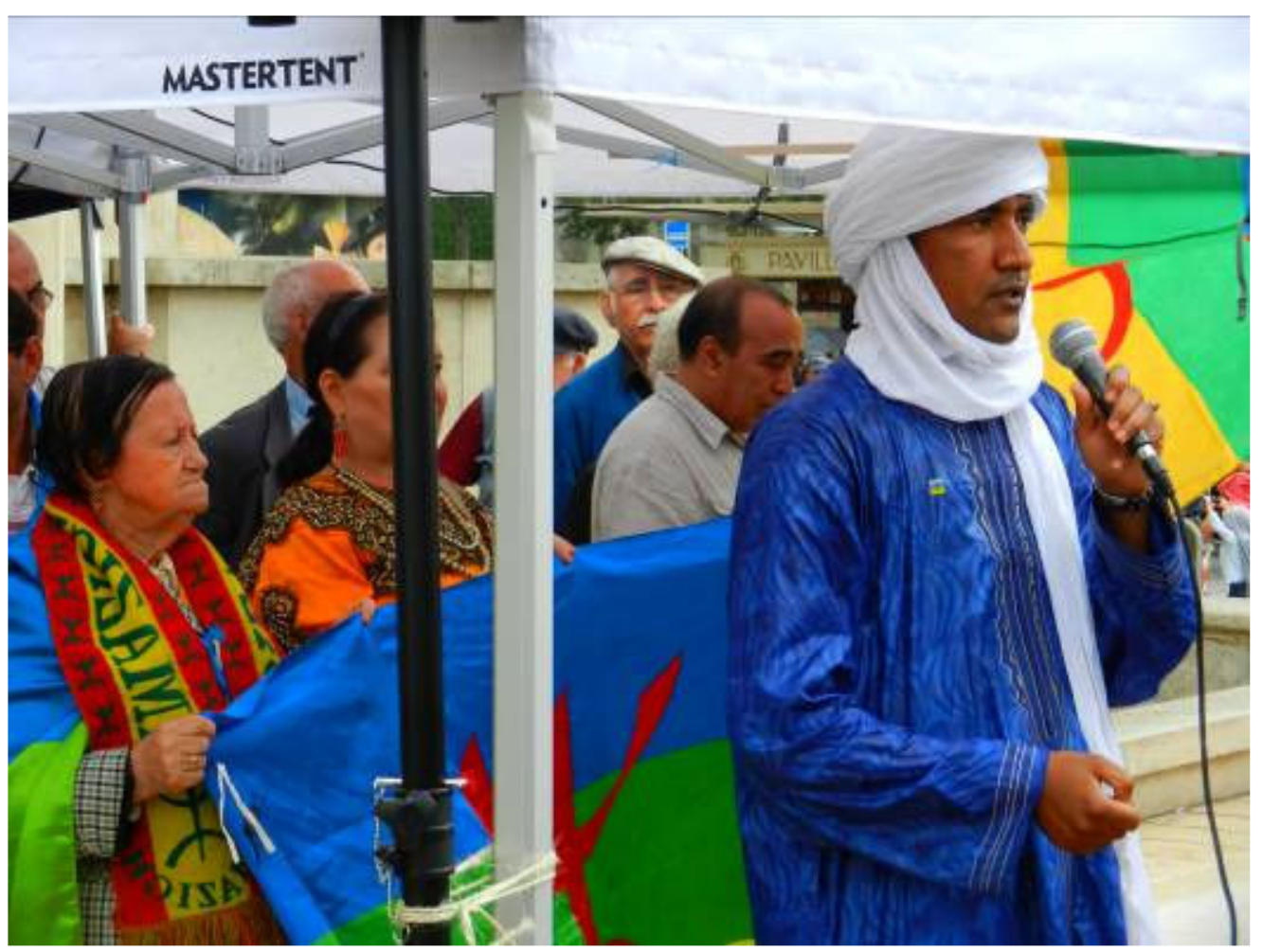

Apêndice 12 - manifestação em defesa do território Azawad (Mali) em Paris, 07/07/2012 De casaco marrom claro e com um bolsa, Brahim Slimani

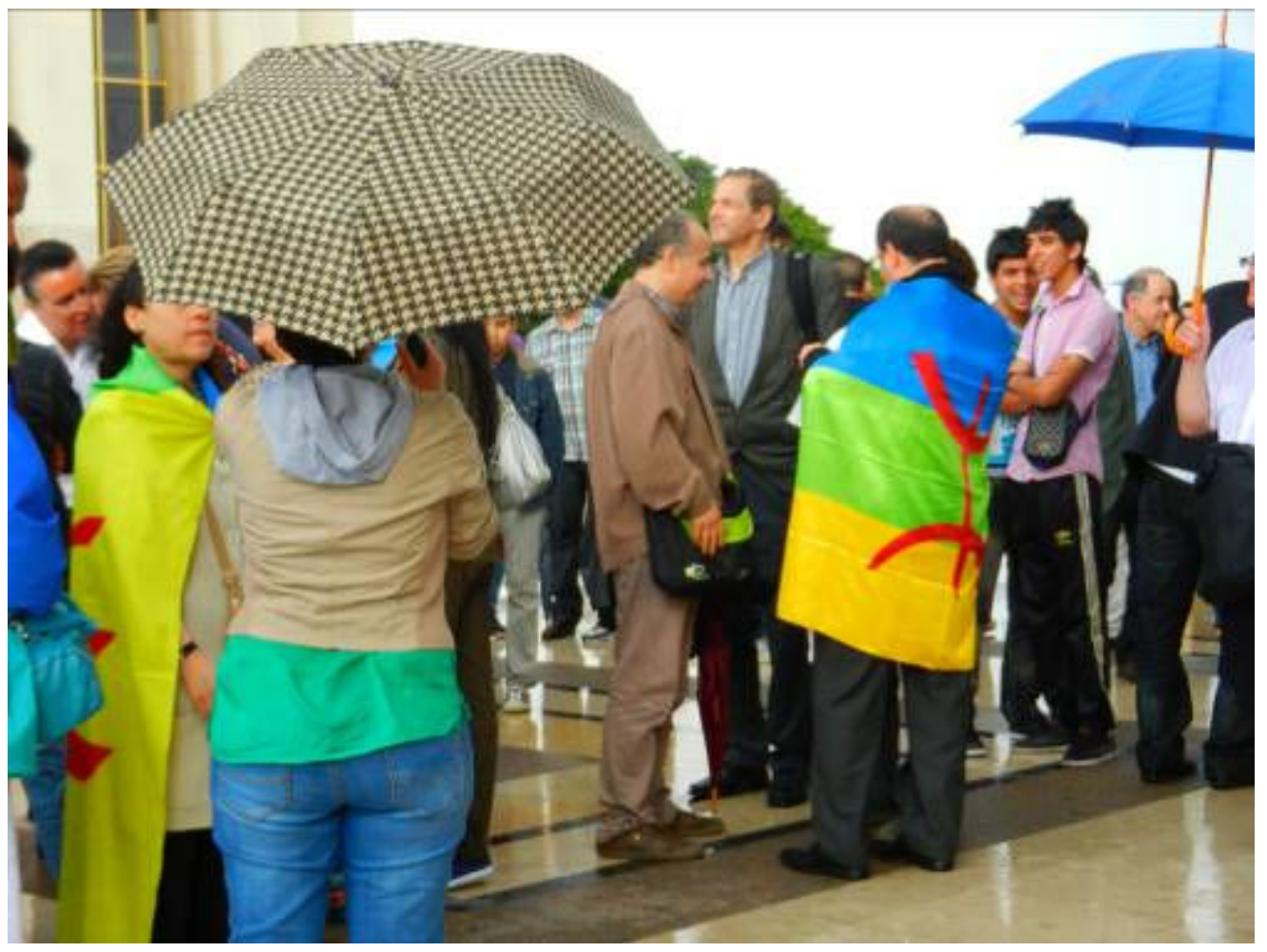


Apêndice 13 - Conferência do escritor Hédi Bouraoui (à direita)- Sede da Associação Cultural Berbere Taferka (Montreuil, Paris, 04/07/2012)

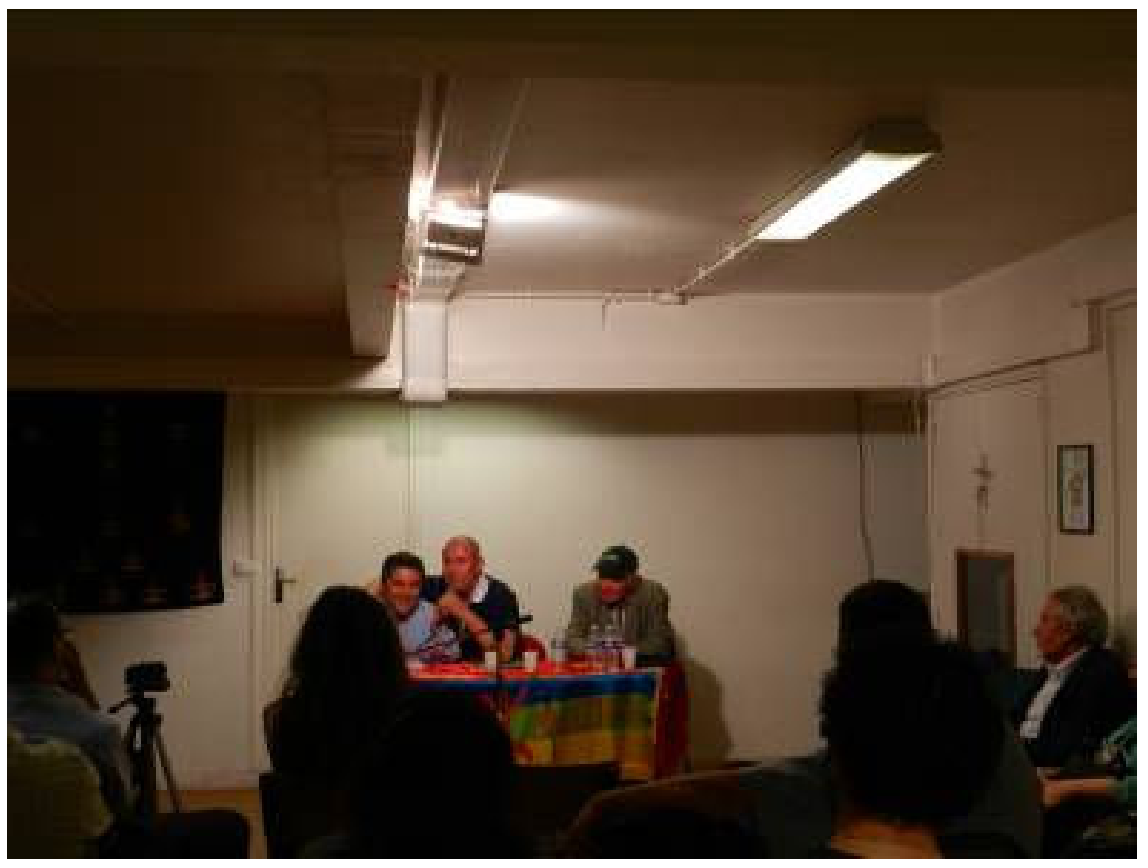

Apêndice 14 - Detalhe da placa da Sede da Associação Cultural Berbere Taferka (Montreuil, Paris, 04/07/2012)

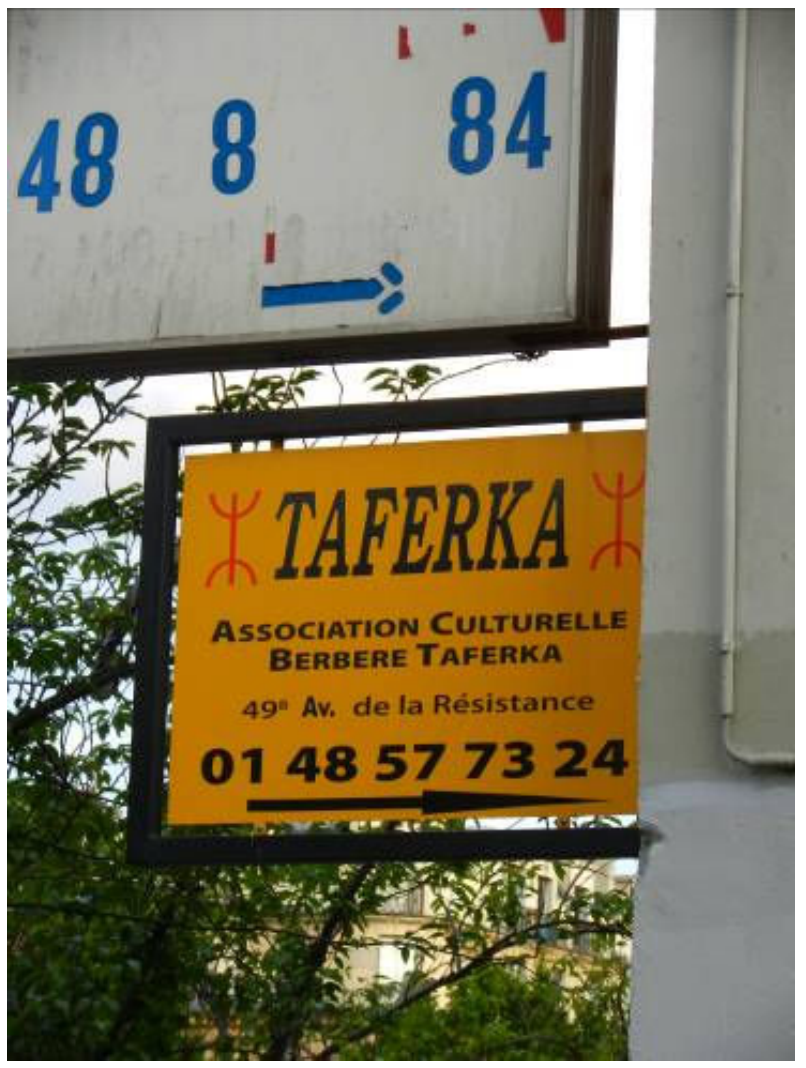


Apêndice 15 - Noite de solidariedade - M. Haddadene. Café de Paris (Oberkcamp, Paris, 23/06/2012)

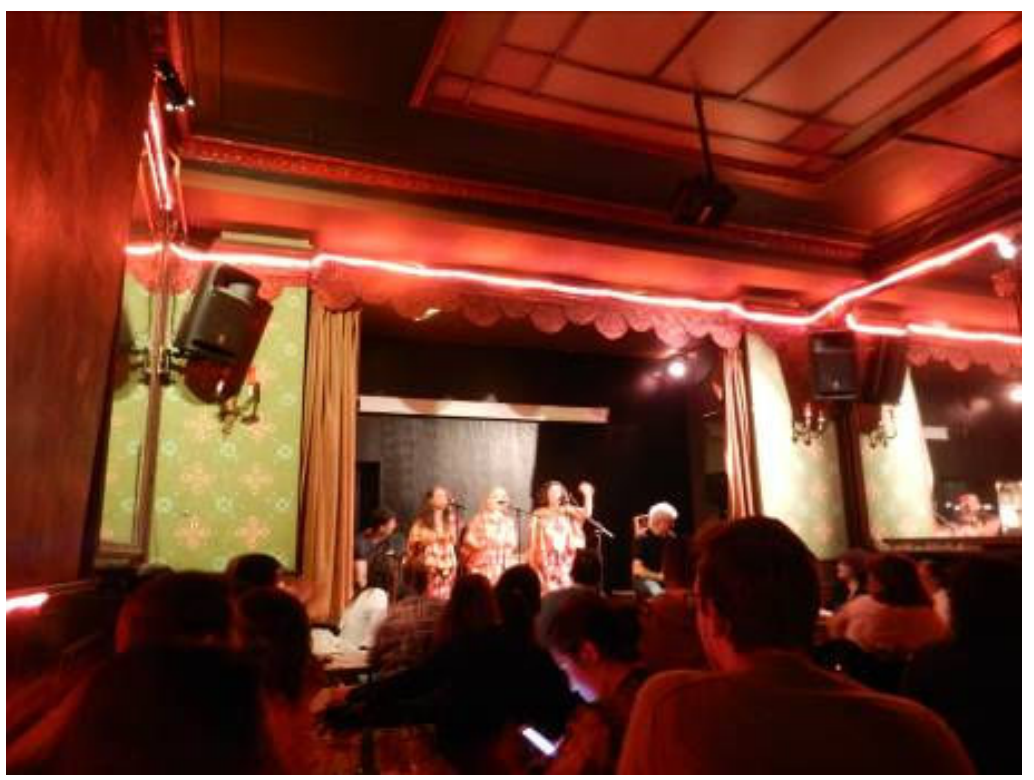

Apêndice 16 - Homenagem ao músico Lounès Matoub. (Montmorency, Paris, 30/06/2012)

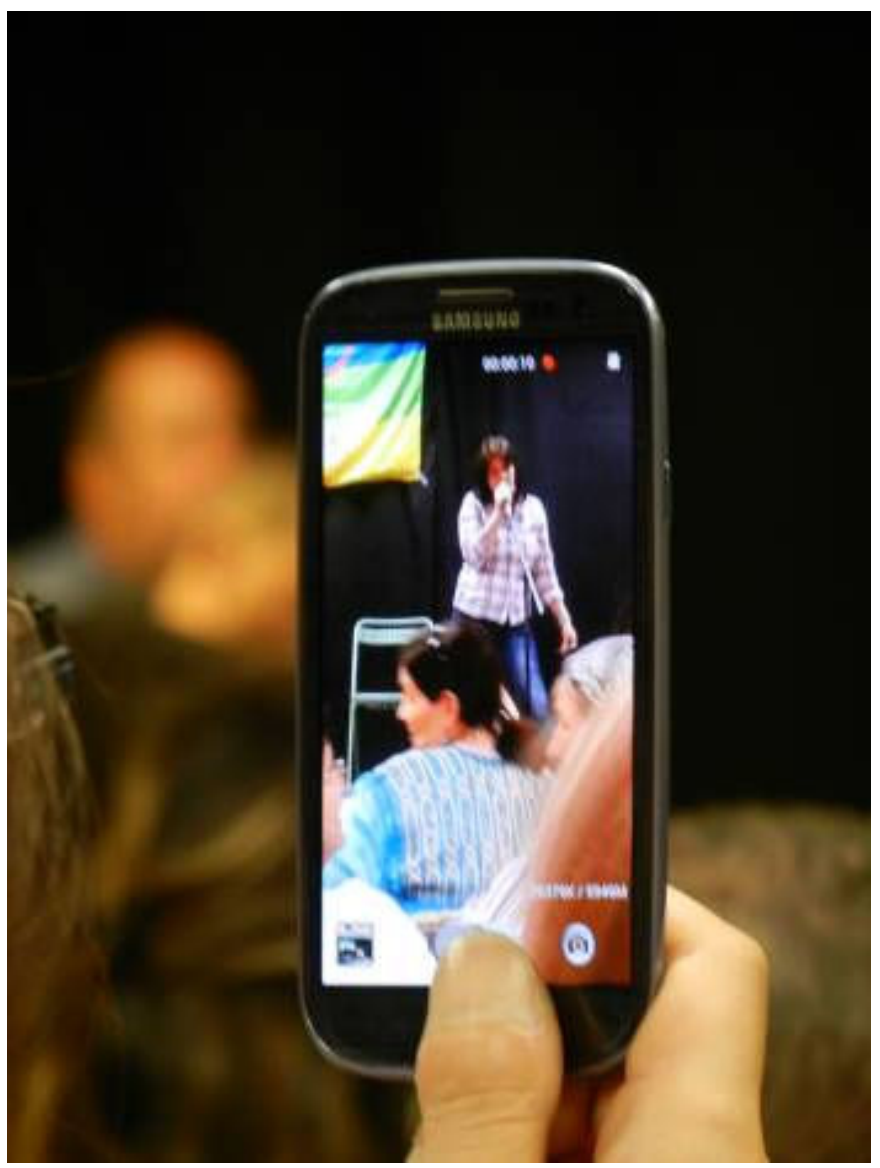


Apêndice 17 - Homenagem ao músico Lounès Matoub. (Montmorency, Paris, 30/06/2012)

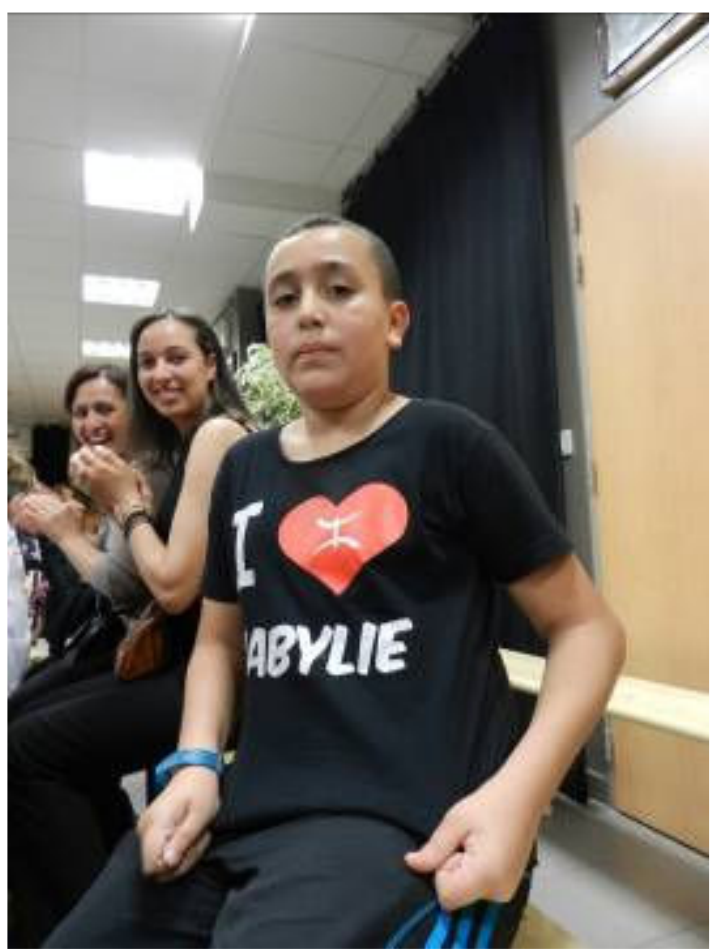

Apêndice 18 - Homenagem ao músico Lounès Matoub. (Montmorency, Paris, 30/06/2012)

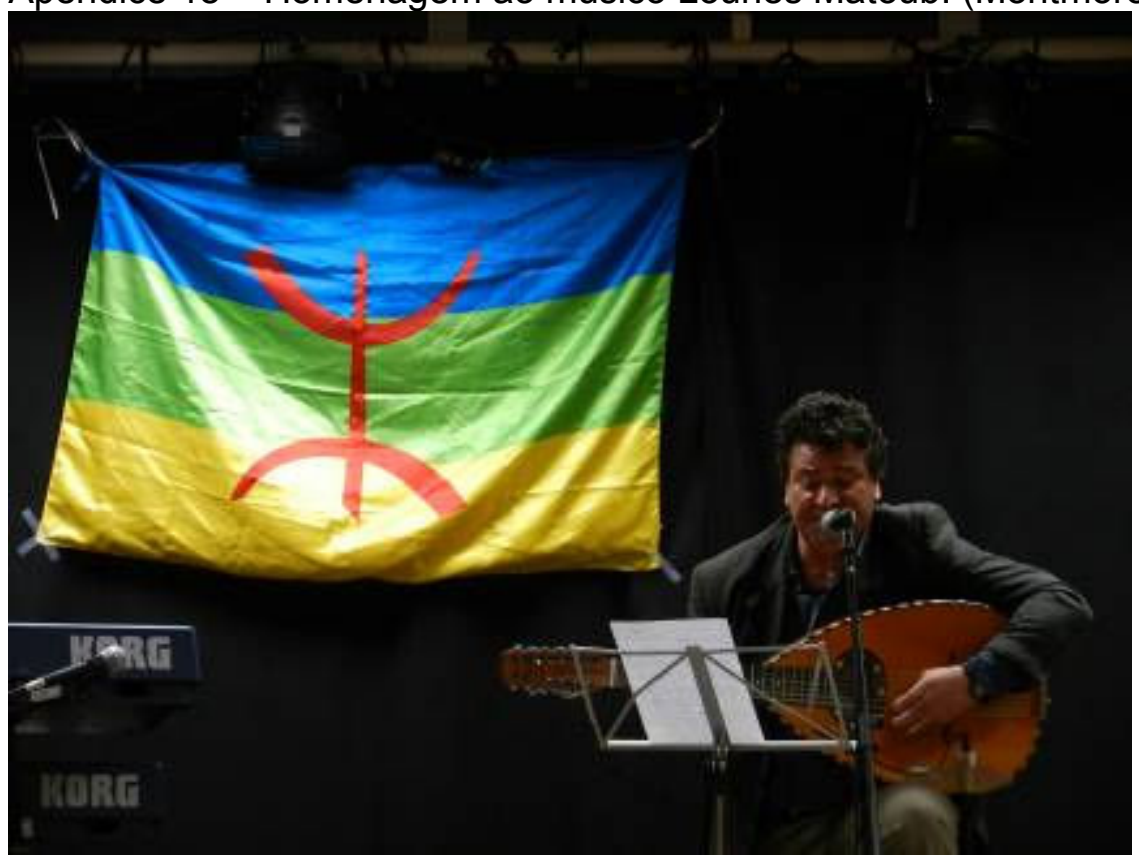




\section{ANEXOS}

Anexo 1 - Centro Yorenka Ãtame - vista aérea - Fonte: Blog Saberes da Floresta

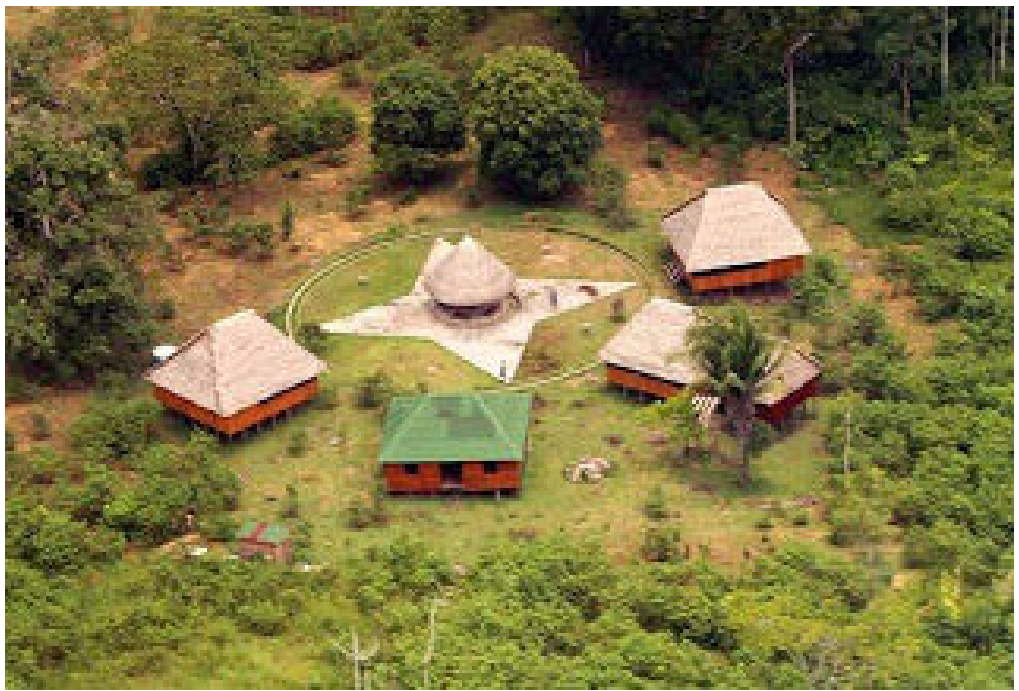

Anexo 2 - Centro Yorenka Ãtame - vista aérea - Fonte: Blog Saberes da Floresta CD Homãpani Ashaninka. Gravado em Julho de 2000 na aldeia Apiwtxa - Acre 2a edição lançada em Janeiro de 2005.

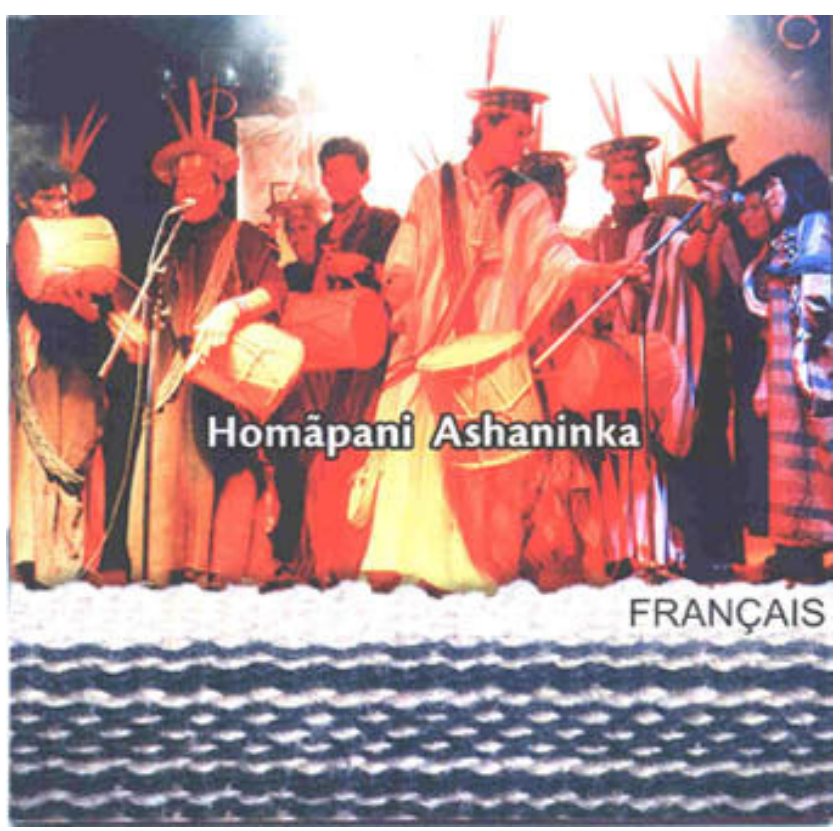


Anexo 3 - Quadro de Benki Pianko. s/d.

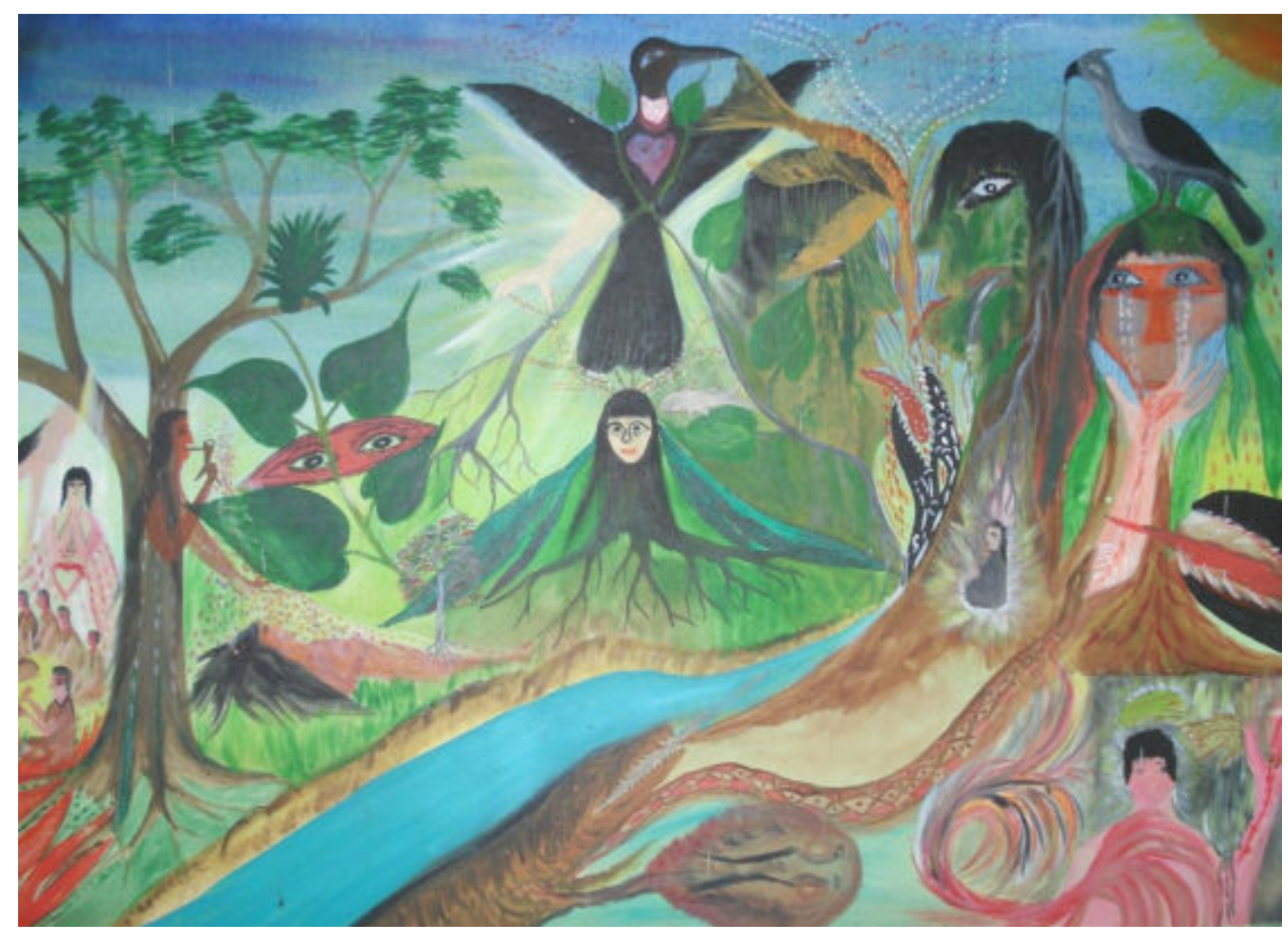


Anexo 4 - Canção "Vavá Inouva" de Idir (1992)

Vava Inouva

Txilek elli yi $n$ taburt a Vava Inouva Ccencen tizebgatin-im a yelli Ghriba Ugadegh Iwahc elghaba a Vava Inouva Ugadegh ula d nekkini a yelli Ghriba

Amghar yedel deg wbernus

Di tesga la yezzizin

Mmis yethebbir i lqut

ussan deg wqarru-s tezzin

Tislit zdeffir uzetta

Tessallay tijebbadin

Arrac ezzin d i tamghart

A sen teghar tiqdimin

Ccencen tizebgatin-im a yelli Ghriba

Ugadegh Iwahc elghaba a Vava Inouva

Ugadegh ula d nekkini a yelli Ghriba

Adfel yessed tibbura

Tuggi kecment yehlulen

Tajmaât tettsargu tafsut

Aggur d yetran hejben

Ma $d$ aqejmur $n$ tassaft

Idegger akken idenyen

Mlalen d aït waxxam

I tmacahut ad slen

Txilek elli yi $n$ taburt a Vava Inouva Ccencen tizebgatin-im a yelli Ghriba Ugadegh Iwahc elghaba a Vava Inouva Ugadegh ula d nekkini a yelli Ghriba
Mon père à moi

Je t'en prie père Inouba ouvre-moi la porte O fille Ghriba fais tinter tes bracelets Je crains l'ogre de la forêt père Inouba $O$ fille Ghriba je le crains aussi.

Le vieux enroulé dans son burnous A l'écart se chauffe

Son fils soucieux de gagne pain Passe en revue les jours du lendemain

La bru derrière le métier à tisser Sans cesse remonte les tendeurs Les enfants autour de la vieille S'instruisent des choses d'antan

Je t'en prie père Inouba ouvre-moi la porte $O$ fille Ghriba fais tinter tes bracelets Je crains l'ogre de la forêt père Inouba $O$ fille Ghriba je le crains aussi

La neige s'est entassée contre la porte L'ihlulen" bout dans la marmite La tajmaât rêve déjà au printemps La lune et les étoiles demeurent claustrées La bûche de chêne remplace les claies La famille rassemblée Prête l'oreille au conte

Je t'en prie père Inouba ouvre-moi la porte $O$ fille Ghriba fais tinter tes bracelets Je crains l'ogre de la forêt père Inouba $O$ fille Ghriba je le crains aussi

Traduction:

http://www.lyricsmania.com/vava_inouva_lyrics_idir.html. Acesso em 11 de janeiro de $201 \overline{2}$. 
Anexo 5 - Foto de Brahim Slimani - presidente da Associação Cultural Apulée

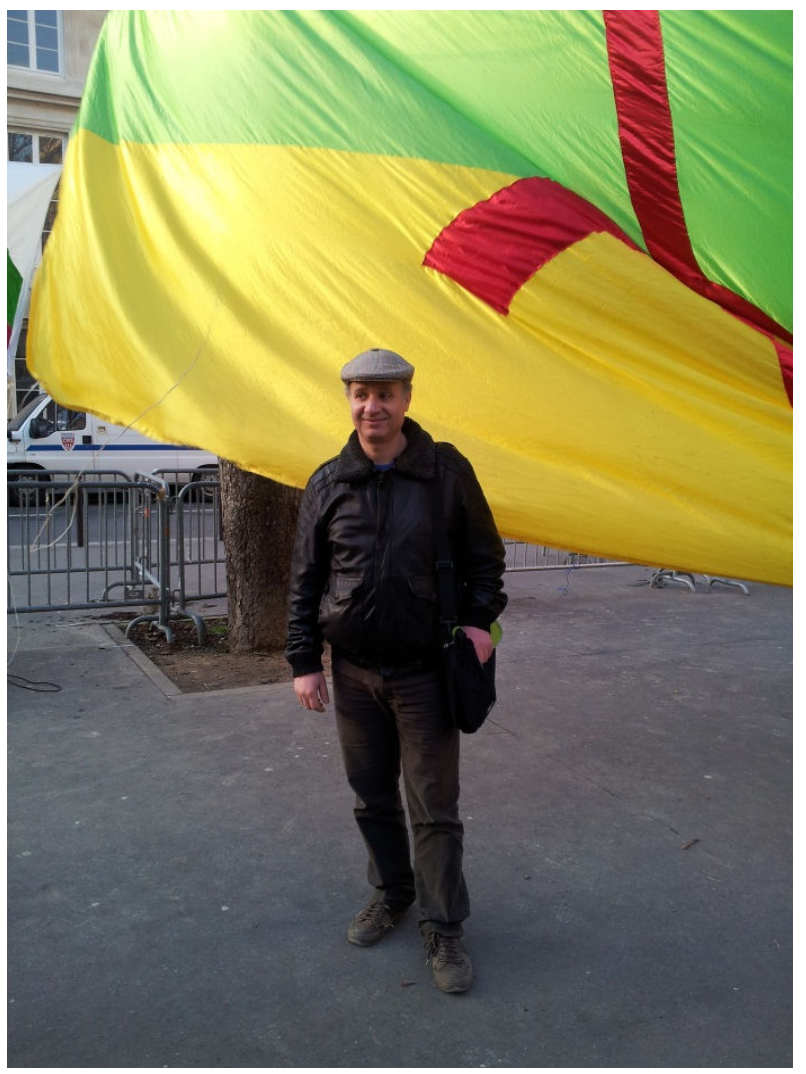

Anexo 6 - Foto de Stéphane Arrami do Kabyle.com - Capturada do seu perfil no Facebook

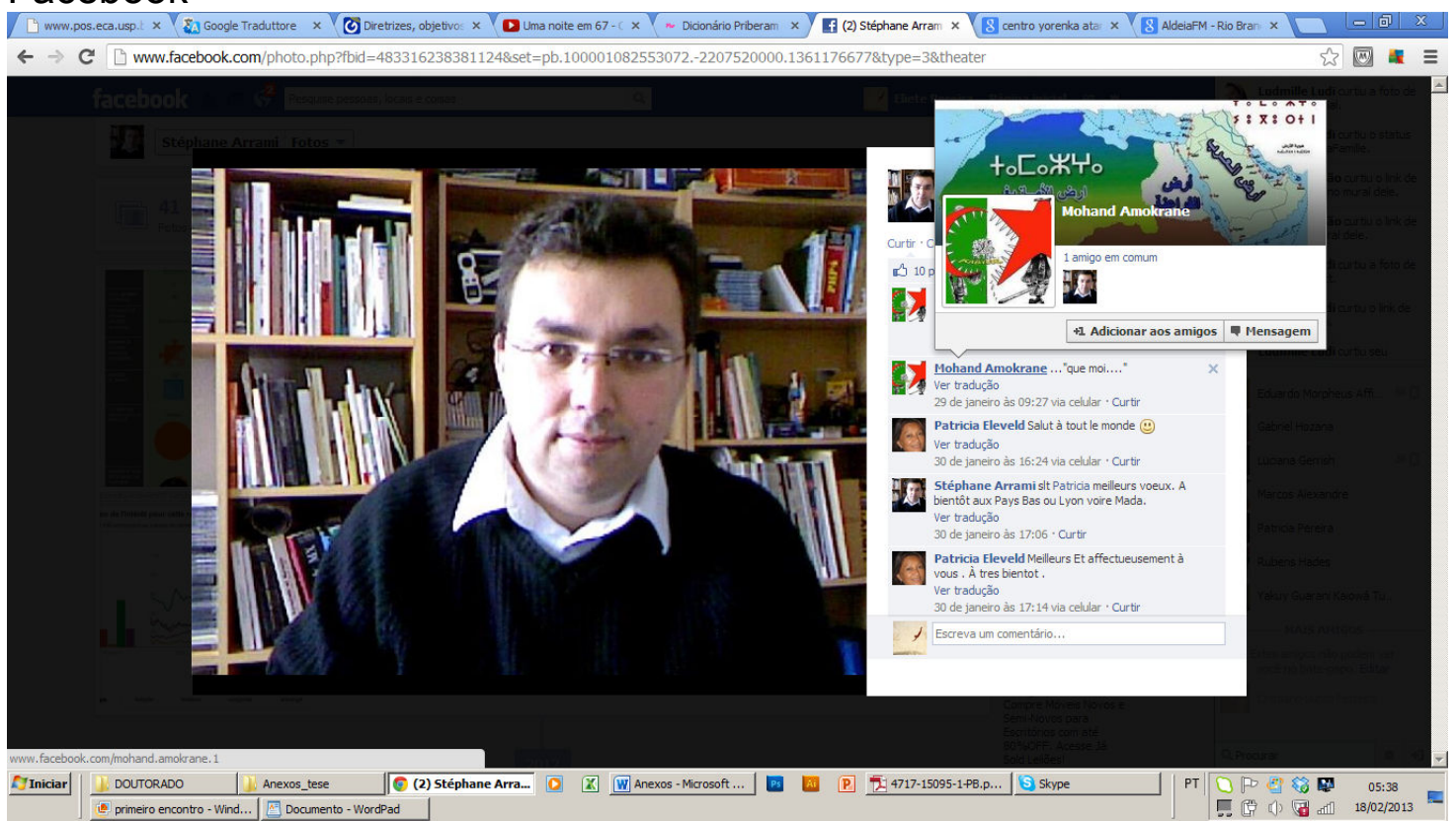


Anexo 7 - Lista de associações amazigh na França

- MOUVEMENT CULTUREL BERBERE FRANCE

129, rue Louis-Lherault

95100 Argenteuil

- COLLECTIF CULTUREL BERBERE

Residence Gaston-Monmausseau,

Appartement 161

33130 Begles

- L'ANNUAIRE BERBERE

8 bis, avenue de Gravelle

94220 Charenton-le-Pont

- ASARU

12, rue de Paris

94220 Charenton-le-Pont

- L'UNION DES FEMMES POUR LA CULTURE BERBERE

27, rue de Bezons

92400 Courbevoie

- Espace franco berbère de creteil Azul

6 à 19 , place des Alizées

94000 Créteil

Tél. : 0143776193

Télécopie : 0149569588

- ARBALOU A LA RENCONTRE DES BERBERES DE L'ATLAS

Hotel des sociétés

7, rue du Docteur-Chaussier

21000 Dijon

- ARBALOU AMITIE ET RENCONTRE DES BERBERES DE L'ATLAS

Centre municipal des associations

2 , rue des Corroyeurs

21000 Dijon

- ASSOCIATION DES CHRETIENS ORIGINAIRES DE KABYLIE ET LEURS AMIS

Eglise Saint-Augustin,

46, boulevard Malesherbes

75008 Paris

- FEDERATION DES ASSOCIATIONS BERBERES

F.A.B. s/c Green-Shop

20, rue Gerando

75009 Paris

- MAISON DE LA KABYLIE

140 , rue de la Roquette

75011 Paris

- INITIATIVES TOUAREGUES

9, rue Basfroi

75011 Paris

- MOUVEMENT CULTUREL BERBERE

c/o Editions Berbères

47, rue Benard

75014 Paris

- MOUVEMENT CULTUREL BERBERE

c/o Editions Berberes 
47, rue Benard

75014 Paris

- MOUVEMENT CULTUREL BERBERE

37 bis, rue des Maronites

75020 Paris

- ASSOCIATION DES BERBERES DE SURESNES

1, avenue Gustave-Stresseman

92150 Suresnes

- ASSOCIATION TILLELI

5, rue Laurent Bonnevay

69800 Saint Priest

Tél.: 0478206125 (Permanences le dimanche à partir de 14h00)

- ASSOCIATION D'AMITIE ET SOLIDARITE FRANCO-ARABO-BERBERE

3 , rue des Ajoncs, appartement 18

44600 Saint-Nazaire

- ASSOCIATION BERBERE DES ETUDIANTS DE REIMS

Faculte de lettres et sciences

humaines, 57, rue Pierre-Taittinger

51100 Reims

- ASSOCIATION DES BERBERES DU PAYS DE MONTBELIARD

3 , rue du Bois-Bourgeois

25200 Montbeliard

- L'AMICALE BERBERE

5 , rue Aime-Audubert

19000 Tulle

- ASSOCIATION CULTURELLE BERBERE : TIWIZI

15 , rue de Greensboro

25200 Montbeliard

- ASSOCIATION POUR LA DIFFUSION DE LA CULTURE ARABO-BERBERE

1 , rue Rosa-Bonheur

76140 Le Petit-Quevilly

- ASSOCIATION KABYLE DEL REART

cite Le Reart, 11, cite del Reart

66600 Rivesaltes

- TAMAZGHA

no 96, batiment A 2, cite Le Parc,

2, impasse de Londres

31100 Toulouse

- ASSOCIATION CULTURELLE DES BERBERES EN LANGUEDOC-ROUSSILLON ET LEURS AMIS

23, avenue de Lodeve

34000 Montpellier

- ASSOCIATION SOCIOCULTURELLE FRANCO-BERBERE DU SUD-OUEST

35 , rue Saint-Laurent

31270 Villeneuve-Tolosane

- TAMAZGHA

10, avenue d'Occitanie,

Appartement 664

31520 Ramonville-Saint-Agne

- ASSOCIATION BERBERE DES ETUDIANTS DE REIMS

Appartement 5F

5, avenue Bonaparte

51100 Reims 
- ASSOCIATION CULTURELLE BERBERE DU MANTOIS

17, place de la Republique

78200 Mantes-la-Jolie

- ASSOCIATION MEDITERRANEENNE DES CHEVAUX DE RACES BERBERES Quartier Pourqueyras 84420 Piolenc

- REFLEXION ET CULTURE BERBERE

31, rue de l'Aiguillerie 34000 Montpellier

- ASSOCIATION POUR LA PROMOTION DE L'ARTISANAT TOUAREG 6 , impasse des Jardins-de-Maintenon 78210 Saint-Cyr-l'Ecole

- MOUVEMENT CULTUREL BERBERE NORD 10-9, chemin des Crieurs 59650 Villeneuve-d'Ascq

- MOUVEMENT CULTUREL BERBERE C.C.O., 39, rue Georges-Courteline 69100 Villeurbanne

- MOUVEMENT CULTUREL BERBERE TOULOUSE MIDI-PYRENEES 1 , rue Jouxt-Aigues 31000 Toulouse

- ASSOCIATION DES KABYLES DE MONTBELIARD 44, rue du Petit-Chenois 25200 Montbeliard

- ASSOCIATION POUR LA DIFFUSION DE LA CULTURE ARABO-BERBERE RADIO FIGINE

45, rue Jean

76300 Sotteville-les-Rouen

- MOUVEMENT CULTUREL BERBERE

3 , rue Jacques-Prevert

69140 Rillieux-la-Pape

- QUERCY-TOUAREG

Les Gouzettes

46150 Nuzejouls

- ASSOCIATION CULTURELLE BERBERE STEPHANOISE

13, rue des Tulipes 42000 Saint-Etienne

- ASSOCIATION DE SOLIDARITE INTERNATIONALE BERBERE 12560 Campagnac

- MOUVEMENT CULTUREL BERBERE

32, quai Saint-Cyr

35000 Rennes

- ASSOCIATION SOCIO-CULTURELLE BERBERE

LA SOUMMAN

20, impasse de la Glassiere

31270 Cugnaux

- LES RANDONNEES DU BERBERE

chez Mme Brun

130 , avenue de la Republique

38170 Seyssinet-Pariset 
Anexo 8 - Entrevista via email com Stephane Arrami desenvolvedor e editor do Portal Kabyle.com. 27/07/2012 (Data do envio das respostas).

\author{
Interview - Stéphane Arrami
}

\title{
Kabyle.com
}

\section{Comment vous est venue l'idée du site Kabyle.com?}

Le média électronique a été créé des les premières heures d'internet à la fin de mes études en communication (ICOM Lyon 2) avec l'idée de transposer et continuer mon travail commencé quelques années plutôt dans un bulletin culturel associatif berbère sur papier avant mon service militaire.

Le site a su tirer profit un an après sa mise en marche en 1997 d'un hébergement à titre gracieux sur une ligne spécialisée chez Webcity.fr ( je travaillais dans cette start-up). Cela a permis de fonder des bases solides. A ce moment là on pouvait encore faire un site seul. Je m'appuyais sur un petit réseau constitué d'une radio locale kabyle à Lyon et du Congrès Mondial Amazigh.

Nous sommes encore bien loin de l'objectif initial : un média avec ses bureaux, ses antennes, ses agences dans un grand nombre de villes d'Afrique du Nord. Le site a été initialement construit avec une assise simple : un chat, des pages où l'on pouvait pour la première fois trouver un calendrier berbère des photos exclusives de personnalités, des ressources, des chansons kabyles traduites, quelques interviews de mon crû et au départ il faut bien le dire bien peu d'informations de Kabylie.

Puis ce fut l'assassinat de Matoub, les interviews de RMC, RFI avec les coupes du monde de Zidane, les reportages au cœur des grands rassemblements de solidarité avec la Kabylie. Kabyle.com a d'abord été connu comme le site de la diaspora kabyle en France avec l'idée de toujours garder cet ancrage francophone, laïque avec un volet ouvert aux débats et à la réflexion un peu à l'image de la Tribune Juive en France.

\section{Comme une activité de l'Association internationale Kabyle-France les mêmes personnes qui participent à l'association font partie de la rédaction de Kabyle.com?}

En réalité le site n'a été sous l'égide d'une association que quelques mois. Kabyle.com est devenue une sarl en 2003 et c'est à ce moment là seulement que j'ai cédé le nom de domaine. Avec un membre des forums devenu le secrétaire de l'association et un ami informaticien de profil administrateur système qui était intéressé de se joindre à nous pour héberger ses sites, nous nous sommes projetés dans la création d'activités rémunératrices qui pourraient faire vivre le site : une boutique, une webradio.

L'hébergement de plus en plus exigeant nous a demandé un investissement que seul un apport financier pouvait solutionner. Jusqu'à une date récente, notre rédaction se résumait à peu de collaborateurs.

Parmi les associés je suis le seul journaliste avec une expérience dans les métiers du web et de la presse papier.

Nous avons fonctionné sur la base d'un forum avec des contributions spontanées ( Ajqas, Zahir Boukhelifa qui parviendra à atteindre le cabinet et l'entourage de $\mathrm{N}$.

Sarkozy, Khaled étudiant en communication en Kabylie qui fut le $1^{\mathrm{er}}$ à nous envoyer des publi-reportages, nous avons perdu sa trace, il serait comme ajqas alias Djamel Beggaz aujourd'hui enFrance ...). Depuis le début de notre activité, il est rare que nous soyons amenés à travailler régulièrement avec plus de deux correspondants sur la même période. Kabyle.com a survécu près de trois ans avec un correspondant unique en Kabylie rémunéré en d'honoraires. Un procès en diffamation avec Berbère Télévision duquel nous aura quand même coûté la bagatelle de 8.000 euros a considérablement ralenti notre activité. Puis Madjid Serrah aujourd'hui à Ligue des Droits de l'Homme de 
Tizi Ouzou, aidé de Hamid Selmi ont pris le relais jusqu'à ce que deux éducateurs de métiers avec une fibre militante nous proposent leurs services dans la région de TiziOuzou et Tigzirt. Les rémunérations se font à l'article (entre 15 et 20 euros, 10 euros pour une brève). En septembre Arezki Bakir (ASKAF Paris), Mourad Hammami (Mizrana Production Tigzirt) viendront renforcer la société et je l'espère constituer notre épine dorsale rédactionnelle et audiovisuelle.

\section{Comment l'équipe éditoriale s'est-elle formée? (Invitation, formation spontanée} etc)

L'équipe éditoriale s'est formée autour d'un socle de contributeurs dont les publications sont assez régulières : en moyenne deux articles par mois chacun. Dalil Maxlufi animateur radio les week-ends(Canut) a rejoint la société Kabyle.com en 2010. II a notamment aidé Kabyle.com au lancement de sa webradio de Radionomy (projet fermé par le service comme de nombreuses webradios sans motifs clairs), également en ressources documentaires.

Tassadit Ould Hamouda présidente de l'association Tafsut à Montréal propose spontanément des interviews, des compte-rendus depuis 2004, c'est la plus ancienne et fidèle du groupe.

Les différents appels lancés sur internet nous ont permis de recruter Samia Ait Tahar et Rabah Ben Amghar. En septembre reviendra dans l'équipe Aziz Kitouche à Bouira correspondant local rémunéré une fois libéré de ses obligations militaires.

Le vidéaste Akim Louhab à Paris, Mokrane Neddaf (auteur de pièces de théâtre) comptent parmi les contributeurs dont les papiers sont régulièrement sélectionnés en grands titres sur notre une. L'écrivain Noufel Bouzeboudja fait partie de ces nouvelles " grandes » signatures.

que nous recherchons.

http://www.kabyle.com/fr/top-lus-2012 - http://www.kabyle.com/fr/top-lus-2011

\section{Quel est le profil professionnel de l'équipe? Sont-ils tous le domaine des communications et de l'ingénierie? Quel est le rôle de chacun dans l'équipe éditoriale?}

Les profils sont variés (du bts d'histoire au dess en multimédia). Nous nous répartirons la rédaction de la manière suivante. Arezki Bakir, la version actuelle de Kabyle.com pour la diaspora en France, Mourad chapeautera avec Rabah l'équipe de rédaction en Kabylie et sera le directeur de la webtv, pour ma part je m'occuperai du volet international et l'Afrique du Nord. Nous fonctionnons en binomes sur chaque domaine d'activité stratégique. A ce jour, je supervise et anime seul les contenus proposés. Techniquement nous gérons à deux la partie serveur.

\section{Comment avez-vous été impliqué dans cette Association et site?}

Ce sont les recherches de ma famille et des origines kabyles qui ont motivé cette implication. Au-delà de l'aspect purement sentimental j'ai toujours rêvé de monter une société de presse couplée à une entreprise culturelle. Depuis l'âge de 14 ans avec un ami tuniso-russe originaire de Tamazret nous réalisions des journaux et avions ensemble rejoint le club de Jeunes La Presse de Tunisie. C'est une implication quotidienne chronophage qui me prend chaque jour de plus en plus de temps.

\section{En tant que rédacteur en chef, quel est leur rôle dans la gestion du site d'informations?}

J'ai essayé de structurer l'équipe rédactionnelle en fonction de la répartition géographique et d'étendre l'information sur lé région kabyle sétifienne. Dans la principale ville culturelle de Kabylie, Bgayet, nous n'avons pas encore de correspondant permanent ce qui est un handicap très important. Nous perdons la moitié du potentiel de lecteurs. Les rédacteurs actuels ont des rôles d'administrateur sur Drupal. Ils devront être formés aux différents modules ajoutés cette année tels que " media ». La liberté est très grande 
quant au choix des sujets. La consigne c'est de donner une information de terrain et d'être présent sur les événements incontournables. Si une brève doit être publiée en urgence, les rédacteurs peuvent la valider sans mon approbation ou celle des admins habitués à l'outil. La connexion en Kabylie est insuffisante dans un contexte professionnel ce qui conduit les rédacteurs à privilégier l'envoi plus facile pour eux par email. Facebook est devenu le café kabyle où l'on est sûr de rencontrer les personnes et de discuter avec eux, même sa propre équipe. Twitter et les outils professionnels ne passionnent guère nos collaborateurs. En deux ans j'ai publié tout seul chacune des news sur ce réseau social. II va nous falloir tagger sémantiquement les contenus. Dès qu'il faut saisir des données, renseigner un annuaire, rédiger du contenu pour le web avec de la curation, la tâche semble encore insurmontable pour le contributeur. Cette vision d'informations de données (data, silos de contenus avec nos propres fortifications sur l'espace du web) doit être mieux appréhendée.

\section{De la création du site à son stade actuel, ce qui a changé en termes d'architecture d'information, les gens impliqués et la portée?}

Le véritable changement a été la scission du site en deux avec Amazighnews.com car nous étions référencés exclusivement sur la Kabylie et le domaine kabyle. Nous fonctionnons par échanges de fils RSS entre sites. Ces flux RSS sont générés à partir des listes de contenus générés avec des vues sur Drupal. Les informations commencent à être programmées à l'avance pour leur diffusion et nous avons mis en place un panneau collaboratif pour le contributeur (workbench). Le passage de spip vers drupal a été notre plus grand changement : nous avons revu notre rubriquage. Les archives de 1997 à 2007 sont encore consultables : vous pouvez vous faire une idée de la différence. Nous comptons 8 à 10 têtes de rubriques l'actu kabylie, tamazha (amazighnews) avec tous les contenus documentaires déplacées pages annuaires, dico, prénoms etc..., l'agenda culturel avec son calendrier, la rubrique sport, l'annuaire $100 \%$ kabyle, les forums (passés de mode), le chat (application rencontre Skadate) et notre boutique de produits culturels sur Drupal Commerce. J'ai tenu à ce que cette boutique prenne une forme éditoriale. Nos deux fers de lance seront la webtv qui sera directement implémentées sur nos sites. La solution Livestream est pour l'instant retenue avec une légère expérience sur cet outil. Une large diffusion impliquera un financement de $200 €$ /mois. Le nombre de membres inscrits est minime comparé aux nombre de visites ( 35.000 visiteurs uniques par mois 55.000 visites).

\section{II s'agit d'un programme pré-défini, ou publiez-vous les principaux faits qui se produisent dans le monde berbère/kabyle? Comment est la mise à jour du site avec un réseau de rédacteurs décentralisé? Comment est le processus de décider ce qui doit être publié ou non?}

Dans la mesure du possible nous essayons de coller à l'actualité internationale et kabyle militante. Nous n'avons jamais réussi à nous conformer à un calendrier de publication. J'ai tenté de mettre en ligne un calendrier partagé sur google agenda, un extranet sur open atrium avec des conseils, prévisionnel des publications mais cela faisait un espace supplémentaire difficile encore à appréhender pour nos coéquipiers. Je fais un point presque toutes les semaines ou j'envoie à l'équipe un point sur la situation, les interviews en préparation par chacun, les évolutions.

Si un article nous parait litigieux nous le laissons en suspend le temps de récolter les avis de l'équipe. Jusqu'ici je choisi les titres en fonction de règles générales de référencement et en fonction des titres déjà publiés précédemment. Un article illustré accompagné d'une photo a toutes ses chances d'être publié en couverture : nous cherchons à diversifier les contenus, passer du sport à la politique, de la musique à l'économie toujours avec cette volonté de remplir des silos de contenus par thématiques. Pour intéresser les lecteurs nous devons les surprendre et les faire rêver. Les critères de surprise, scoop et désir sont donc prioritaires. 
9. Il ya eu un certain désaccord quant à la publication? Qu'est-ce et comment a-t-il été résolu?

Des désaccords ont pu survenir. Récemment, nous avons coupé court avec un journaliste professionnel à Tizi-ouzou. Ses papiers donnaient l'impression d'avoir été écrit à chaque fois à distance sans se rendre sur le terrain avec un formatage que l'on retrouve dans la presse algérienne, mais surtout sans que l'on sente un véritable engagement ni citoyen, ni éducatif. Pour l'article de Samia Ait Tahar sur la visite de Ferhat en Israel, le plus délicat à gérer à ce jour, il a été placé avec une série de contenus favorables à cette visite. La ligne de Kabyle.com est humaniste mais l'idée d'une libération spirituelle et territoriale de la Tamazgha et de la Kabylie par sa diaspora et son peuple principalement en Kabylie est prépondérante. Nous n'hésitons pas à parler de colonisation arabe en Kabylie, à souligner l'importance du devoir de mémoire aussi bien vis-à-vis de la Kabylie (1857-1871 déportations) que de la terre ancestrale berbère (palais de Koceyla)...Notre vision est bien détachée de celle des identitaires qui prônent le rejet de l'autre et promulguent un rejet de l'islam. Nous avons eu à nous défaire de ces extremistes que j'ai publiquement qualifié de kmayels, les kmers jaunes, lequels se sont retrouvés sur des sites où ils exhibent leurs frustrations.

\section{Quel type de plateforme est développée sur le site? II est open source?} Pourquoi opter pour ce type de plateforme?

La plate-forme est mixte composée de logiciels commerciaux (vbulletin, skadate) et open source . Les sites sont prioritairement développés sur Drupal. Le désaccord s'est davantage révélé sur cette partie plutôt que sur le contenu. Nous nous tournons de plus en plus vers des webservices. Kabyle.com sponsor du Drupal Camp à Lyon envisage de devenir une société de services informatiques en Kabylie spécialisée sur Symfony, Drupal. Drupal s'est imposé naturellement car initialement ce framework est basé sur un forum communautaire et un excellent moyen de différentiation.

\section{Contenu (récits et représentations)}

11. Dans une interview avec vous en 2001, à Capucine Gabin (le site Afrik.com 25/06/2001), en commentant sur l'importance de la politique du site de l'objectivité (Em suas palavras: "La berberité est un sujet três sensible, qui divise les Kabyles, nous devons rester objectifs"), qui sont des questions politiques controversées entre les Kabyles?

La politique peut etre le broyeur des bonnes volontés pour les Kabyles, mais elle est surtout la moelle épinière structurante de notre combat culturel.

Les questions politiques controversées en Kabylie sont principalement celles de la séparation ou de la création d'un Etat régional de Kabylie. Le mot kabyle est nouveau sur l'échiquier politique. La génération précédente parlait de Printemps berbère, d'associations franco-berbères. Les kabylo-kabyles, les « kabylistes » avec leurs nouveaux repères dérangent les nationalistes algériens autant que la tranche des 55-65 ans plus ou moins berbéristes qui se sentent largués, dépossédés de représentativité politique ( $r c d, f f s . .$.$) et assez méfiants des projets plus structurés que présenteront les$ franco-kabyles

Notre vision fédéraliste consensuelle sur Kabyle.com ne frustre aucun kabyle, ni les partis institutionnels (RCD, FFS), ni les autonomistes, ni les berbéristes (partisans d'un Etat fédéral transnational), ni les fédéralistes algériens (Rachid Ali Yahia, Malika Baraka ...)

12. Au cours des deux dernières années (2011 et 2012) qui étaient les thèmes qui ont prévalu sur le site et le Forum? Quelle est votre opinion? 
Notre site a dénoncé « la descente aux enfers » des artistes kabyles, n'hésitant pas jouer de provocation pour fustiger les dirigeants sportifs de la JSK, un symbole identitaire passé aux mains du pouvoir algérien.

Nous avons dû nous démarquer des sites autonomistes et nous concentrer essentiellement sur des thématiques de la société civile (environnement, traditions, culture).

Nous produisons de contenu de type magazine : des portraits en couverture, peu de dépêches, des reportages.

\section{Interfaces - (architecture de l'information)}

13. En termes d'interactivité avec les utilisateurs du site, quelles sont les espaces plus accessibles? Les messages? Le forum ou chat?

Le chat irc a été abandonné et dès sa disparition celui de beurfm qui aspirait nos utilisateurs a lui aussi périclité. Freenode n'offre pas d'applet java agréable pour les utilisateurs : nous venons d'ouvrir un canal de support uniquement. L'achat d'une licence de Cometchat n'a pas été renouvelé en raison du faible retour d'utilisateurs. Là aussi relancer un chat nécessiterait un investissement disproportionné. Nous envisageons d'acheter une application Vbulletin pour une interaction plus réactive avec Facebook.

Les espace les plus visités sont les commentaires mais les réactions ne sont plus aussi importantes qu'avant en volume. C'est une nouvelle problématique qui nécessitera une reconfiguration des espaces et valorisation des icones de commentaires, taille du texte dans les messages. Nous sentons clairement qu'il faut chercher redynamiser une communauté qui a constaté de nombreuses dérives dans les commentaires (insultes, attaques personnelles...). Kabyle.com commence à se libérer de cette image de défouloir, mais du coup les visiteurs sont de moins en moins enclins à réagir.

14. Il ya des données précises sur le nombre de visites quotidiennes sont effectuées? Ces accès sont pour la plupart fabriqués à l'étranger ou dans les Kabyles? Vous avez les données que le langage est le site le plus visité, le chat et le forum?

Nos statistiques proviennent des google analytics pour plus de fiabilité. Les données en provenance de Kabylie sont faussées par les connexions depuis les cybercafés, des filtres trop généralistes (un niveau de profondeur pas assez suffisant sur les villes kabyles).

Globalement les internautes restent plus longtemps sur le site qu'avant et visitent plus de pages.

La Kabylie ne fait plus la une des médias internationaux elle de plus en plus transparente. Nous devons composer avec cet essoufflement du combat identitaire par cycles et donc moins de visites. Cela va nous conduire à revoir notre modèle publicitaire.

\section{Zone d'interaction et d'une connexion / un groupe / technologie \\ 15. Comment les technologies de communication influencent la sociabilité de la communauté kabyle en France?}

Notre site a servi d'exutoire : il était important de donner la parole alors qu'en Algérie les journaux quotidiens en ligne sont très frileux dans ce domaine mais nous avons globalement opté sur éditorialisation du contenu plutôt que de travailler en profondeur sur une communauté version webcity.fr, (les modules sociaux sur Drupal sont consommateurs de ressources og par exemple, users points, localization, faceted search sur les profils utilisateurs également). Nous sommes l'un des rares sites à proposer un système de vote sur les commentaires (la lecture est déjà socialisée à l'intérieur du site) et @kabyle est considéré comme étant l'un des 30 comptes twitter " algériens » les plus influents. Les Kabyles n'ont quasiment pas investis Twitter, cela mérite sans doute analyse. 
Nos pages communautés de nos membres ont tenté de regrouper les utilisateurs par villes mais les interactions ne sont pas encore assez suffisantes.

\section{Pour vous, comment les technologies de communication influencent les liens sociaux de la communauté kabyle en France avec les Kabyles en Kabylie?}

Une fois sur Kabyle.com nous sommes dans le village global kabyle. Nous avons affaire le plus souvent à des anonymes où la provenance importe peu. Les joutes verbales entre kabyles algérois et ceux du pays kabyle sont assez fréquentes. Je retiendrai que les projets sur le web se font en liaison directe avec la Kabylie aujourd'hui que rien ne se fait sans les Kabyles de Kabylie.

\section{Quelle est votre impression su l'impact du site dans la communauté kabyle à l'étranger? Quel est le rôle du site de la diaspora kabyle?}

Kabyle.com jouit d'une image plutôt positive pour plusieurs raisons : un site non partisan c'est le site de tous, un site qui résiste aux épreuves du temps, un site toujours aux premières places sur les moteurs de recherche. Kc manque énormément aux gens dès que subissons une coupure, nous perdons en crédibilité et nous peinons à retrouver notre rythme de croisière (audience). Lire Kc est rentré dans les habitudes de consommation de l'actualité pour un Kabyle sensibilisé à la cause. Les Kabyles sont majoritairement encore dans le symbole. Notre site joue un rôle de représentation : en attend de nous à ce que nous valorisions et donnions une bonne image des Kabyles, que nous fassions rayonner sa culture.

Notre site est diversement apprécié par les associations kabyles à l'étranger. Le Président de la CBF (ancien président de l'association awal à Lyon) critiquait en apparté notre façon de traiter l'actualité. Pour lui nous avons délaissé le volet de l'intégration citoyenne et républicaine en France, nous n'avons pas aidé à renforcer notre représentativité. Pour lui nous nous attardons sur la Kabylie, ce qui n'est pas notre rôle. D'autres associations trouvent dans notre média un relai d'information (agenda plus que réflexion). Je déplore le manque d'échanges réels avec elles. D'autres notamment au Canada aimeraient jouer de leur position avantageuse sur le continent nord-américain et de l'apport anglophone et ont diversement appréciés nos articles où nous dénoncions leurs accointance avec les consulats algériens.

\section{Quel est le poids politique de l'opinion publique à l'étranger communauté kabyle sur le territoire de la Kabylie?}

La communauté kabyle de France, que l'on peut aussi appeler diaspora selon moi au regard de l'histoire de notre peuple est plurielle. La jeune génération a dû déconstruire les codes culturels marginalisants, faussée de la culture dite « beur et orientale ». A peine débarrassée elle se trouve en proie à la hallalisation des masses ce que ne manquent pas d'exploiter les sites identitaires kabyles, elle reçoit un message politique mal ficelée. La plupart des jeunes de France pensent que le drapeau berbère c'est le drapeau kabyle. Les cours de langue sont quasi inexistants et peu de famille prennent en considération la langue dans l'éducation. Les modèles de réussite sont rares. Les " passeurs de mémoire " sont des situations d'échec insurmontables. II est temps que les Kabyles de France se réveillent et consacrent leur temps aux vivants.

Le CMA a été volontairement réduit à néant en Kabylie. Des jeunes redonnent de l'espoir mais il nous faudra faire masse.

\section{Quel est le rôle du site dans la défense du territoire de la Kabylie?}

Je ne pense pas que le site soit considéré et à tord comme un outil de défense du territoire de la Kabylie. Le site de "l'Etat Kabyle » et son agence rempli cette fonction et siffone une partie de nos lecteurs depuis 2010. Kabyle.com est l'un des rares sites à fournir des cartes et des repères permettant de mieux appréhender la structure traditionnelle politique kabyle 
(curation sur les travaux de chercheurs du cnrs Alioui etc...). Nous réussirons cette défense le jour où nous fédérerons autour de nous les bibliothèques, centres culturels en Kabylie, le jour où nous arriverons à travailler directement en lien étroits avec des ong et des Etats. Notre priorité pour l'heure est de renforcer le lien stratégique avec l'ASKAF association des Kabyles de France et d'autres associations bien ciblées choisies pour leur affirmation kabyle dans leurs statuts et leurs activités.

\section{Identité Numérique et Technologies de la Communication 20. Pour vous, quelle est la relation entre identité culturelle kabyle et technologies numériques de communication?}

De prime abord ces technologies nous servent à améliorer nos supports éducatifs (cartable interactif pour l'écolier berbère ghiles Ikni par exemple) mais elles vont surtout rapprocher les peuples sur des problématiques communes et recréer des alliances identitaires ( " tectonique des espaces antiques imaginaires, rêvés ou idéalisés») bassin libyco-basque tel que perçu Joseph Henriet. Une e-diplomatie parallèle des peuples peut voir le jour où la nation kabyle sera correctement représentée. http://ediplomacy.afp.com

L'enjeu actuel c'est d'être présent et pris en compte par ces logiciels open source (traductions), les webservices, les evn numériques (démultiplier l'offre en vidéos à la demande), être représentés dans les banques d'images notamment celles liées à l'actualité, créer nos propres agences de communication et d'imagerie, intensifier l'usage du mobile en tamazight premier support de communication direct.

La technologie numérique c'est un moyen d'intéresser directement les jeunes à leur culture d'origine (plaisir de la découverte interactive, réalité augmentée). Son appropriation par la jeunesse est un marqueur identitaire positif.

\section{Quelle est la spécificité culturelle de la communauté kabyle dans un contexte multiculturel de la France?}

La communauté kabyle était encore il ya vingt ans relativement ignorée malgré sa présence (la première communauté d'origine étrangère en France). La France n'a toujours pas signée la charte européenne des langues étrangères : quelque Kabyles contribuent à faire pression. L'économie, le réseau communautaire musulman, la mode orientale, le vote communautaire musulman (ce qu'on a appelé la naissance d'une économie beur), l'enseignement de l'arabe (bien que ralenti en raisons de coupes budgétaires) sont hégémoniques et suffisants pour anéantir notre volonté d'indépendance et d'émancipation culturelle.

Les sites orientalement.com, mektoube, bledchat, monbled sous le label « maghrébin » exercent un rapport de force (achats de mots clés...). La déperdition est inévitable : un lecteur se contente de quelques espaces de lectures (saturation, recherche de la source fiable). Nous essayons tant bien que mal de montrer chaque jour cette spécificité culturelle (histoire propre, langue) qui ne peut pas être non plus celle de la France des couleurs « black blanc beur » cf idir avec ses derniers albums (identités) complètement artificielle.

\section{Finance et gestion}

\section{Quel soutien? Comment le site est-il financé?}

Les soutiens institutionnels sont quasi-inexistants. Nous comptons trois « mécènes » qui placent de la publicité. En Kabylie, se montrer sur Kabyle.com présente un risque pour un opérateur économique, mais c'est en Kabylie principalement que nous pourront faire décoller notre activité. Nous avons pu compter l'année dernière sur la publicité du Courrier International sur une durée de trois mois qui nous a fait le plus grand bien. En dehor, les producteurs des artistes renommés (Ait Menguellet) sont les plus indéliquats. Le soutien moral de l'association Arpitania et du Gouvernement de Savoie est capital car nous nous inscrivons dans ce même combat. Les Editions Berbères Tamazgha, les Editions Sybous 
nous facilitent l'acquisition de produits pour la boutique actuellement en stand by. Le site est financé comme le serait une association en juste équilibre. La publicité nous rapporte 300 euros (Adsense, régie), cela ne pèse pas très lourd. La boutique génère 1000 euros de CA sur un an, ce qui est très rédibitoire.

\section{L'équipe de rédaction reçoit un salaire ou une allocation?}

Nous luttons contre nous même et évitons de trop valider de papiers. Quelques correspondants attendent leurs soldes de tout compte à ce jour (des petites sommes). Il est fort probable que $80 \%$ du contenu de demain au moins sur une année soit réalisé par les actionnaires journalistes (Arezki, Mourad et moi-même).

24. Quel est le coût de la maintenance (serveurs, les paiements de paiement du personnel et toutes les dépenses inhérentes au site)?

La raison nous imposerait d'arrêter l'entreprise mais la problématique serait la même en association. Ce qui nous sauve c'est que nos charges se limitent essentiellement aux impôts obligatoires et l'hébergement et frais pour $3500 €$ à l'année.

$\mathrm{Si}$ je ne m'impliquais pas autant avec passion le site n'existerait pas de toute évidence. Je dois m'occuper de la comptabilité, de la relation client, de la maintenance technique, des courriers, quasiment de tout. Espérons que les conditions s'améliorent avec l'arrivée de deux nouveaux collaborateurs.

\section{Les projets et le futur}

\section{Quels sont les projets qui sont actuellement en cours d'élaboration sur le site?}

L'orientation générale est portée sur la vidéo pour arriver à créer une webtv kabyle sur le modèle de Rhône-Alpes TV avec des bouquets thématiques. Les projets Mizrana TV et Amazigh24 (Berbère 24) devraient fusionner. Nous promettons au moins un jt en images et grand débat en différé obligatoirement sous titré s'il est en kabyle (réalisé à Paris et en Kabylie) avec deux plateaux (associations partenaires). Nous allons élaborer des contrats avec les associations pour un échange de visibilité digitale (conférences...).

La vente des produits berbères mais cette fois ci avec nos propres produits (teeshirts jeux éducatifs - reportages).

Nous relancerons les speed-dating et soirées avec un restaurant partenaire à Lyon et Paris. La rubrique sorties kabyles sera couplée avec une sélection de pages commerçantes facturées avec une nouvelle page chaque mois qui mettra en valeur l'enseigne et le kabyle du mois.

26. Quelles sont les perspectives pour l'avenir du site, en tenant à l'horizon quotidien de l'importance des personnes qui utilisent les réseaux sociaux comme Facebook? II ya des plans pour l'avenir? Qu'est-ce?

Facebook est utilisé comme un outil de prospection. $25 \%$ de contenu du site pourrait provenir de ce réseau. Notre stratégie de maillage du terrain, le recrutement de nos experts doit se faire par ce canal. Nous n'avons pas encore trouvé notre community manager.

\section{Les thèmes spécifiques}

\section{Comment pourriez-vous décrire le kabyle d'identité?}

Au travers d'une conversation, un membre actif de Wikipedia me disait que la communauté kabyle était la plus difficile à appréhender et à modérer. Le Kabyle n'est jouit pas d'un capital 
sympathie très positif en France, on dit de lui qu'il est« opportuniste, raciste peu ouvert aux autres».

Le franco-kabyle s'est en grande majorité fondu dans la masse. Le lien essentiel à l'identité n'est pas la communauté religieuse, la communauté ethno-linguistique mais la famille à la rigueur les cousins du village.

Le kabyle d'identité (à ne pas confondre avec le kabyle identitaire) exhibe son drapeau, il s'affirme en tant que tel, il cherche à se rassurer sur l'éducation qu'auront ses enfants (rencontres si possible entre kabyles). II est désireux d'ouvrir des espaces capables de motiver sa vie, mais ce n'est jamais la kabylité qui conditionne sa vie. En Kabylie, la jeunesse cherche à s'éloigner de son quotidien et je pourrais presque parler d'une identité mutilée où la seule la mondialisation intéresse.

\section{En ce moment et la situation, vous vous sentez kabyle, où la différence se dégage avec plus de force et de distinction?}

Personnellement je suis venu à ma communauté de l'extérieur et j'ai toujours gardé un détachement me sentant métis franco-kabyle né en France, de lignée amazighe, éduqué en Tunisie avec une vision berbériste de la Kabylie. Le sentiment nationaliste a grandi mais pour moi il ne se limite pas à la Kabylie. Le terme de " vrai kabyle » c'est généralisé. Un amazigh porte sur lui l'aza où n'est pas comme un juif pour maggen david. II symbolise ma croyance : je porte sur moi la mémoire de mes ancêtres, le sceau de mon identité et de ma berberitude tout autant que ma kabylitude. J'ai mal quand un kabyle rejoint le camp algérien. Mon idéal c'est une équipe kabyle aux J.O., c'est préserver aussi la langue kabyle du berbère unifié qui se trame au Maroc ! Donc oui la distinction s'opère par la force des choses. Si vraiment les Kabyles ne se sentaient pas Kabyles, Kabyle.com n'aurait jamais résisté aux épreuves du temps.

\section{Quel est le rôle de la littérature et la musique dans la culture kabyle?}

C'est un vaste sujet. Je dirai que l'essentiel de la production culturelle kabyle se fait par ce biais, mais à la fois le Kabyle cherche la facilité. En France, très souvent on ne se déplace pas à un concert pour encourager découvrir un jeune talent mais pour retrouver des connaissances danser s'oublier. Combien de livres lit un Kabyle aujourd'hui ? Dispose-t'on d'un seul grand centre culturel indépendant avec sa grande bibliothèque en Kabylie ? Combien de festivals indépendants ? Les écrivains et les chanteurs n'ont quasiment jamais de sites internet. Le page musique représente $0,75 \%$ de notre contenu visité. La page livres $0 \%$ ! Je serais presque tenté de dire que l'offre est 100 fois supérieure à la demande.

\section{Comme la religion islamique chez les Kabyles diffère de celle qui est pratiquée par d'autres personnes?}

Les acteurs de cette kabylité les plus productifs sont des personnes qui sont parvenues à s'extraire de l'islamité. La société kabyle était scindée en trois classes sociales que le citoyen kabyle moderne semble se donner pour mission d'unifier : les nobles autchtones laïcs, les clercs Marabouts et les Abids(tribus au service). Des tentions ont été ravivées récemment par les identaires kabyles qui aimeraient se débarrasser de l'islam et ont parfois démontré leur soif de revanche sur les marabouts qui détenaient le monopole de la connaissance. La religion a été intégrée au cœur de la société. L'islam n'est pas l'intégrateur. Une différence est faite entre les marabouts de Basse et Haute Kabylie. En Basse Kabylie les marabouts sont considérés comme des amusnaws, nobles et issus des familles des empires unitaires berbères (sanhadja, rahmania, kotamas chiites du 10ème siècle...). L'islam a été prépondérant en Basse Kabylie. En Haute Kabylie la transmission de l'islam ne s'est pas opérée de la même manière elle s'est faite par des fiqhs des maîtres religieux pour beaucoup d'entre eux non kabylophones. Donc la religion musulmane est polymorphe en Kabylie et ne peut être réduite aux seuls concepts de rites « malékite ou kharjite ». 


\section{Quelle est la spécificité de l'option politique laïque en tenant compte de l'influence de I'Islam chez les Kabyles?}

Jusqu'ici avec l'ancrage de la société traditionnelle (campagnes, hautes montagnes) la taajmaat (assemblée de village), présidée par le mezwer (majoral) garantissait la séparation du religieux et de la vie de la Cité. Le Kabyle n'obéissait pas au lois du Coran mais aux lois collectives du Qanoun, aujourd'hui il se réfugie dans les modèles qui s'offrent à lui tous sauf les siens. L'aristocratie kabyle notamment en Haute Kabylie par essence laïque et laminée par la répression de 1871 a trouvé sa continuité avec la conception de la laïcité française et universaliste. Mais il faut bien y voir une conception de la laïcité hautement élitiste. La laîcité en Kabylie est loin d'être un mythe et elle ne peut se comprendre qu'en se représentant les schémas de l'organisation territoriale kabyle et des institutions séculaires kabyles (lire Youcef Allioui Les Aarchs tribus berbères de Kabylie).

\section{Comme la communauté kabyle socialise en France?}

Les lieux de travail ont regroupé les Kabyles qui ont cherché à placer leur investissement dans un lieu sûr mais à la fois de transit (lire à ce sur Kabyle.com l'histoire de l'immigration kabyle convoyeurs) et où l'on y noie le chagrin de l'exil : les bars et les cafés. C'est peut-être en partie ce qui explique que les Kabyles se soient retrouvés dans la petite restauration et constituent à eux seuls près de $75 \%$ des patrons de bards (sources Ricard).

Cette socialisation s'opère donc principalement par le café-bar. Les projections, quelques concerts sont font encore dans ces « espaces dits culturels ». C'est par ce biais que l'on trouve rapidement un travail dans la maçonnerie ou les chantiers pour les nouveaux venus. Ce serait si peu dire que les réunions ministérielles du GPK se font elles aussi dans les bars. Les cercles du CERAK et les tentatives au Sénat opérées par l'Association des Kabyles de France sont assez caractéristiques de cette tentative de socialisation kabyle autour des reflexions sur l'autonomie territoriale de la Kabylie. Mais à ce jour je n'ai vu aucun échange concret en mesure de rapprocher les deux rives (université d'été France-kabylie par exemple, un banque commune franco-kabyle pour monter des projets, un fond d'investissement spécifique, une entité chargée de repertorier et de mettre en relations les patrons des entreprises kabyles et franco-kabyles).

\section{Gouvernement Provisoire Kabyle.}

a. Quelle est votre perception sur le gouvernement et le mouvement pour l'autonomie kabyle? Et la perception de la communauté kabyle en France?

Les sondages archivés sur notre indiquent que les Kabyles de France sont largement acquis à l'idée de l'autonomie voire de l'indépendance. Cependant Kabyle.com est majoritairement consulté par un public averti et acquis à cette cause. II serait temps que les Kabyles de France diligentent de grandes enquêtes nationales.

Nos relations avec ce " groupe " sont assez conflictuelles. Si nous entretenons de cordiales relations avec Ferhat Mehenni et quelques uns de ses proches ( Aghyul Bruynner forumiste chef de cabinet, Yasmina Abouzar, Nafa Kirèche ancien président de l'ASKAF), nos collaborateurs ont eu à subir des pressions, des insultes venant de leur garde rapprochée ( le cas de Tassadit Ould Hamouda, Samia Ait Tahar). Il fut un temps où l'agence de presse du GPK chercha à nous discréditer et faire taire des voix discordantes.

D'un point de vue politique, le GPK est en pleine mutation en phase d'expansion notamment après la visite médiatisée en Israel.

Je suis personnellement impliqué au sein du Conseil National Kabyle installé en Kabylie sensé préparer le terrain pour un Etat Régional.

b. Quelles sont les relations de ce groupe avec le gouvernement français? 
Une certaine distance avec ce groupe ne nous permet pas de répondre avec précision sur cette question. Arezki Bakir résume assez bien la situation dans un éditorial signé dans les colonnes de Kabyle.com « Le pouvoir algérien, c'est la France ».

\section{Merci beaucoup!}

Eliete Pereira - Doctorat Sciences de la Communication - Universitè de São Paulo (Brésil) elipereira@usp.br 